
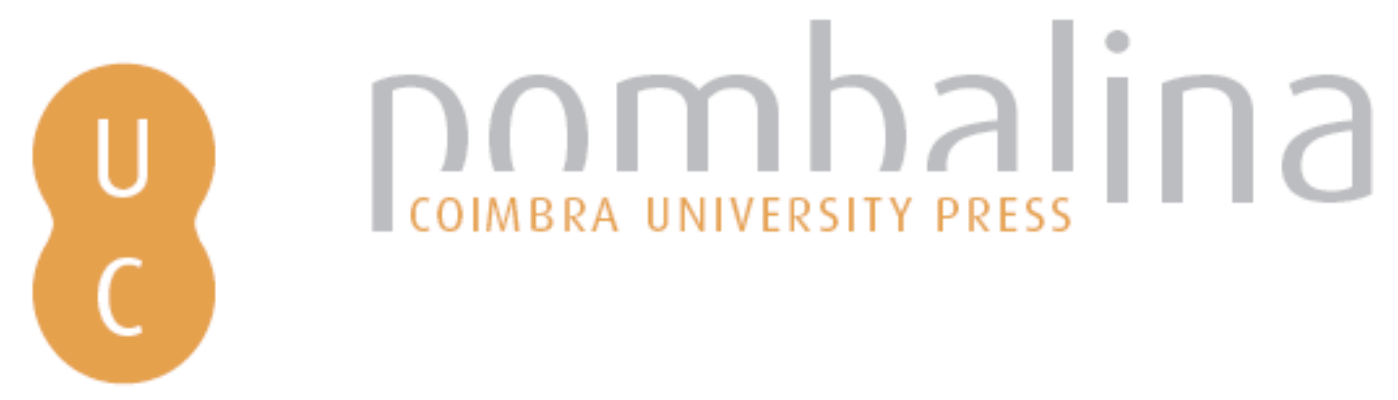

\title{
Grandes conflitos da história da europa: de Alexandre Magno a Guilherme "o Conquistador"
}

\author{
Autor(es): $\quad$ Monteiro, João Gouveia \\ Publicado por: Imprensa da Universidade de Coimbra \\ URL \\ persistente: URI:http://hdl.handle.net/10316.2/11958 \\ DOI: $\quad$ DOI:http://dx.doi.org/10.14195/978-989-26-0311-7 \\ Accessed : $\quad$ 26-Apr-2023 11:25:08
}

A navegação consulta e descarregamento dos títulos inseridos nas Bibliotecas Digitais UC Digitalis, UC Pombalina e UC Impactum, pressupõem a aceitação plena e sem reservas dos Termos e Condições de Uso destas Bibliotecas Digitais, disponíveis em https://digitalis.uc.pt/pt-pt/termos.

Conforme exposto nos referidos Termos e Condições de Uso, o descarregamento de títulos de acesso restrito requer uma licença válida de autorização devendo o utilizador aceder ao(s) documento(s) a partir de um endereço de IP da instituição detentora da supramencionada licença.

Ao utilizador é apenas permitido o descarregamento para uso pessoal, pelo que o emprego do(s) título(s) descarregado(s) para outro fim, designadamente comercial, carece de autorização do respetivo autor ou editor da obra.

Na medida em que todas as obras da UC Digitalis se encontram protegidas pelo Código do Direito de Autor e Direitos Conexos e demais legislação aplicável, toda a cópia, parcial ou total, deste documento, nos casos em que é legalmente admitida, deverá conter ou fazer-se acompanhar por este aviso.

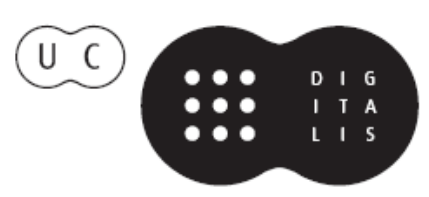




\section{GRANDES CONFLITOS DA HISTÓRIA DA EUROPA}

DE ALEXANDRE MAGNO A GUILHERME "O CONQUISTADOR"

JOÃO GOUVEIA MONTEIRO

:NAVIGIO:

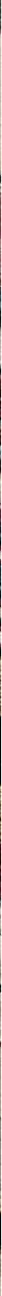

IMPRENSA DA

UNIVERSIDADE

DE COIMBRA

COIMBRA.

UNIVERSITY

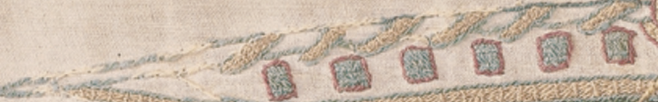

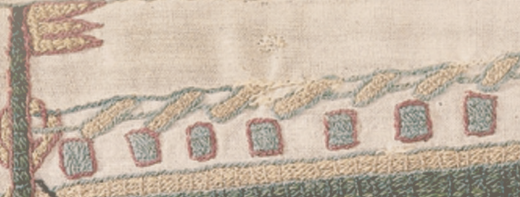


(Página deixada propositadamente em branco) 


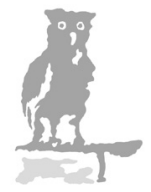

I

N

V

$\begin{array}{llll}\text { E } & S & \text { T } & \text { I }\end{array}$

G

A

C $\quad \tilde{A} \quad 0$

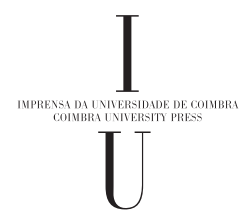




\title{
EDIĈ̃̃
}

Imprensa da Universidade de Coimbra

Email: imprensauc@ci.uc.pt

URL: http//www.uc.pt/imprensa_uc

Vendas online: http://www.livrariadaimprensa.com

\author{
CONCEPÇÃO GRÁFICA \\ António Barros \\ REVISÃO \\ Maria de Fátima Lopes \\ INFOGRAFIA DA CAPA \\ Carlos Costa \\ PRÉ-IMPRESSÃO \\ António Resende \\ EXECUÇÃO GRÁFICA \\ Gráfica de Coimbra \\ ILUSTRAÇ̃̃O DA CAPA
}

Pormenor da Tapeçaria de Bayeux - Séc. XI Com autorização especial da cidade de Bayeux

ISBN

978-989-26-0154-0

ISBN Digital

978-989-26-0311-7

DOI

http://dx.doi.org/10.14195/978-989-26-0311-7

DEPÓSITO LEGAL

$343863 / 12$

OBRA PUBLICADA COM O APOIO DE:

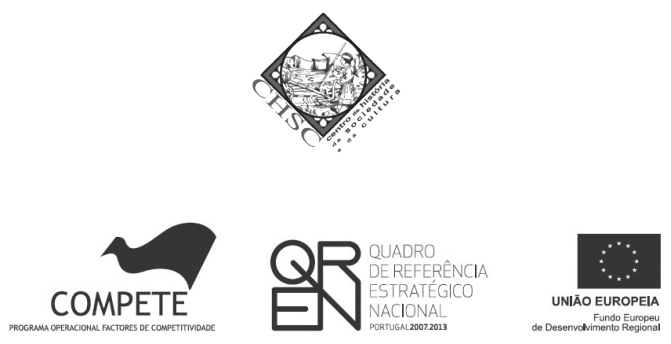

(C) ABRIL 2012, IMPRENSA DA UNIVERSIDADE DE COIMBRA 


\section{GRANDES CONFLITOS \\ DA HISTÓRIA DA EUROPA}

DE ALEXANDRE MAGNO A GUILHERME "O CONQUISTADOR"

\section{JOÃO GOUVEIA MONTEIRO}

ESQUEMAS DAS BATALHAS, MAPAS

E ADAPTAÇÃO DE OUTRAS ILUSTRAÇÕES

JOSÉ MORAIS

IMPRENSA DA

UNIVERSIDADE

DE COIMBRA

COIMBRA

UNIVERSITY

PRESS 
(Página deixada propositadamente em branco) 
Ao José Eduardo Braga, por muitos anos de amizade e de ensinamentos, científicos e humanos. 
(Página deixada propositadamente em branco) 


\section{ÍNDICE}

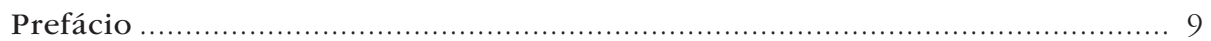

Capítulo I - Gaugamela (331 a. C.): Alexandre Magno

- conquistar a Pérsia e depois o Mundo. 17

Capítulo II — Canas (216 a. C.): Roma e Cartago

- a guerra pelo Mediterrâneo............................................. 73

Capítulo III — Adrianopla (378): quando o Ocidente muda de mãos............ 109

Capítulo IV — Poitiers (732): alarme na Gália perante os muçulmanos . 141

Capítulo V - Hastings (1066): a conquista de Inglaterra - um dia para mudar a Europa 189

Cronologia Sumária 329

Índice das Ilustrações 331 
(Página deixada propositadamente em branco) 


\section{PREFÁCIO}

Este livro é um sonho antigo. Depois de três décadas a investigar e a lecionar temáticas de história política e militar antiga e medieval, acalentava o desejo de escrever um dia um volume reunindo estudos acerca daquelas que eu considero serem as batalhas mais importantes da história do Ocidente europeu. Não pretendia com isso reentrar na velha polémica acerca do 'lugar' da batalha no contexto da arte militar ocidental. Longe disso. Este livro é tanto de história política como de história militar, no sentido tradicional do termo. Nele, a batalha é 'apenas' o pretexto para iluminar toda uma época relevante da história da Europa, para conhecer de forma mais profunda e mais completa alguns dos seus maiores protagonistas, para compreender melhor as motivações e o alcance de alguns dos conflitos que ajudaram a construir o Velho Continente.

Confesso que, de início, hesitei bastante na escolha dos "grandes conflitos" a considerar na obra. A seleção não era fácil, tanto mais que pretendia cobrir um arco cronológico bastante amplo. Pensei incluir dez casos, mas depressa percebi que isso me obrigaria a ser demasiado superficial, ou a produzir um livro volumoso e de consulta desagradável. Fixei-me então no número de cinco e optei por ordenar os conflitos segundo uma sequência cronológica, do mais antigo para o mais recente, tendo assumido desde o início a preocupação de os interligar o melhor possível. Com tudo isto, a narrativa acabou por ficar situada entre a segunda metade do séc. IV a. C. e os finais do séc. XI d. C. São catorze séculos de história europeia numa casca de noz, uma temeridade evidente, mas de que me não arrependo, pois poucos projetos de fôlego me foram tão gratificantes quanto este. 
Se a experiência for bem-sucedida e as condições de trabalho mo permitirem, talvez prossiga esta aventura amanhã, organizando nova viagem pela história político-militar europeia, desta feita entre os finais do séc. XI e os meados do séc. Xv. Daí em diante, é território que não ousarei pisar.

Se à partida lhe disser, caro leitor, que os cinco casos eleitos estão acima de qualquer reparo, responder-me-á que sou suspeito. Por isso, o melhor será ajuizar por si próprio. Ainda assim, não me coibirei de justificar aqui a minha seleção.

O livro abre com Gaugamela, uma batalha travada em 331 a. C., entre Alexandre Magno, rei da Macedónia, e Dario III Codomano, o "Grande Rei" da Pérsia. Gaugamela (ou Gaugamelos, no atual Iraque) constituiu o clímax da grande campanha conquistadora levada a cabo, entre 334 e 324 a. C., por Alexandre Magno, para muitos o maior general da Antiguidade e por quem Napoleão nutria uma profunda admiração. A reconstituição é feita a partir de uma fonte muito credível: o relato de Arriano, um escritor romano de língua grega nascido nos finais do séc. I d. C. e que se baseou no diário de campanha de um dos generais de Alexandre, Ptolomeu, assim como num outro registo, atribuído a um especialista grego que acompanhava a expedição, Aristobulo, que terá transcrito para o seu diário um documento do comando persa contendo a ordem de batalha de Dario III em Gaugamela! O estudo desta batalha é especialmente interessante e multifacetado, porque não é possível compreender o tremendo êxito do exército macedónico sem desvendar previamente os segredos da arte militar da Grécia antiga (com destaque para a célebre falange hoplita, expressão militar da solidariedade comunitária, que era a essência da cidade-estado grega) e sem conhecer as matrizes da arte militar oriental (egípcia, assíria e, em especial, persa). Não se pode compreender o sonho de Alexandre, discípulo de Aristóteles, sem evocar a obra política de seu pai, o rei Filipe II da Macedónia, que foi capaz de federar o ressentimento helénico contra os Persas e que, inspirado pelos desenvolvimentos recentes da arte militar praticada em Tebas, renovou profundamente o pequeno exército macedónico, tornando-o uma máquina de guerra pouco menos do que invencível. Por fim, falar de Alexandre Magno e das suas conquistas até para lá das fronteiras entre a imensa Pérsia e a Índia é também falar da disseminação pelo Oriente e pelo Norte de África do legado cultural helénico, parte integrante e valiosíssima do património cultural europeu. 
O segundo caso considerado neste livro é o do conflito político-militar entre Roma e Cartago, que conduziu às famosas Guerras Púnicas (relatadas por dois grandes escritores clássicos: Políbio e Tito Lívio) e, em especial, à batalha de Canas, travada no sudeste da península itálica no ano 216 a. C. Nessa época, Roma e Cartago eram duas grandes potências em acesa disputa pelo controlo do Mediterrâneo. A Segunda Guerra Púnica ficaria marcada por uma incrível odisseia interpretada por Aníbal Barca, o general cartaginês que conduziu o exército púnico desde a sua base na Hispânia até ao norte de Itália, atravessando os Alpes com milhares de homens e de elefantes e surpreendendo os Romanos, que derrotaria depois numa série de batalhas, até se fixar na região da Apúlia, nas proximidades de Bari. Roma, sentindo a ameaça, tanto mais que os Cartagineses estavam a atrair para a sua causa uma série de povos, mobilizou-se: organizou um imenso exército e enviou-o com ordens rigorosas para enfrentar o inimigo e para pôr fim à tragédia. Todavia, esse grande exército - comandado pelos cônsules Lúcio Emílio Paulo e Gaio Terêncio Varrão e que incluía nada menos do que oito legiões - acabaria por se despedaçar num quente dia de agosto entre a montanha de Canas e o rio Ofanto, num espaço de menos de cinco quilómetros quadrados, onde lutaram perto de 130000 homens e cavalos! Foi a maior derrota militar de sempre da história romana, e o desaire abalou profundamente o Senado, ele próprio devastado pela morte de um número elevadíssimo dos seus membros. A manobra tática de Aníbal Barca na batalha de Canas ainda hoje é estudada nas academias militares e inspirou muitos generais posteriores. Porém, nem isso garantiu a vitória de Cartago nas Guerras Púnicas: a força política de Roma, a sua capacidade para resistir às adversidades e os seus inesgotáveis recursos humanos acabariam por imprimir uma reviravolta no conflito, que só terminaria em 146 a. C., com a destruição da cidade de Cartago às mãos de Cipião Emiliano.

Vem depois a história do conflito que conduziu à batalha de Adrianopla (na atual Turquia), travada em 378 d. C., entre um exército romano chefiado pelo imperador do Oriente, Valente, e um exército visigodo liderado por Fritigerno, que contava nesse dia com a colaboração de contingentes militares montados de Ostrogodos, de Hunos e de Alanos. A batalha de Adrianopla, para cuja reconstituição contamos com o precioso testemunho de Amiano Marcelino (escritor coevo e oficial do exército romano), tem 
muito interesse do ponto de vista militar, uma vez que se tratou do maior combate terrestre da história do Baixo Império romano, da pior derrota de Roma às mãos de um inimigo estrangeiro desde o séc. III e, provavelmente, da única batalha campal em que os bárbaros que invadiram e devastaram o Império alcançaram uma vitória esmagadora sobre os Romanos. Em Adrianopla, reconhecemos facilmente algumas das maiores fragilidades da outrora toda-poderosa máquina de guerra romana: mau comando, fraco trabalho de scouting, indisciplina, dificuldade em lidar com a forte cavalaria bárbara, entre outras. No entanto, maior ainda é o significado político da batalha de Adrianopla. Para muitos - entre os quais me incluo -, ela assinala o verdadeiro início das invasões bárbaras, o canto do cisne do maior e mais duradouro império que a Europa alguma vez construiu. A derrota e morte do imperador Valente em Adrianopla haviam provado que as legiões da águia já não eram invencíveis, pelo que nada ficou como dantes. Três décadas depois, os bárbaros estavam às portas de Roma. Era um velho mundo que se desmoronava e era também o início da construção de uma nova Europa.

O quarto conflito considerado neste livro conduz-nos à região de Poitiers, no centro-oeste da Gália. Entre Poitiers e Tours, teve lugar, num dia de outono de 732 d. C., uma batalha que opôs o dux Francorum ("chefe dos Francos"), Carlos Martel, a um poderoso exército muçulmano liderado pelo governador árabe do al-Andalus, Abd al-Rahman al-Ghafiqi. Os muçulmanos desejavam ampliar até às margens do rio Loire o controlo que já exerciam sobre algumas regiões da Gália meridional, de forma a estenderem definitivamente o seu domínio ibérico além dos Pirenéus. Coube a Carlos Martel, avô de Carlos Magno e talvez o maior general da história da Europa na Alta Idade Média, travar esse sonho, confinar os muçulmanos a uma estreita faixa do sul da Gália (de onde foram, pouco depois, afugentados) e preservar, desse modo, o cristianismo como religião dominante no continente europeu. O alcance político, cultural e religioso da vitória de Martel, de facto o iniciador da grande dinastia dos Carolíngios, é evidente, mas a batalha de Poitiers também vale por si própria: foi um dos principais combates da Alta Idade Média europeia e proporciona uma reflexão de conjunto muito rica acerca das formas de fazer a guerra no Ocidente dos séculos $\mathrm{V}$ a IX. Para esta reflexão, raramente ensaiada entre nós e mesmo a nível 
europeu, as fontes são muito avaras, ao ponto de a própria data rigorosa da batalha permanecer em dúvida e de não se saber se ela se desenvolveu em dois dias ou apenas num só! Servimo-nos sobretudo dos relatos insertos na Continuação de Fredegário (uma obra preparada por iniciativa de dois membros da família carolíngia, entre os quais Childebrando, meio-irmão de Carlos Martel) e na Continuatio Hispana, uma fonte hispânica coeva que, por ter sido composta (em ambiente moçárabe: toledano ou sevilhano) por volta do ano 754, é igualmente conhecida por Crónica de 754. As dificuldades de conciliação e interpretação dos dois relatos são evidentes, mas também isso é pedagógico e ajuda a compreender as dificuldades do historiador, sobretudo quando confrontado com cronologias mais recuadas e com universos onde a cultura escrita estava limitada a uma pequena elite clerical. Se houve um capítulo que me deu um gosto especial preparar, foi certamente este, dedicado à batalha de Poitiers: tudo nele foi descoberta, e o desafio era tremendo, a começar pela identificação dos traços nucleares da história política da época, envolta em episódios sangrentos perpetrados a uma velocidade vertiginosa por protagonistas de nomes estranhos e de ambições desmedidas...

O livro encerra com o mais longo de todos os capítulos, o que dediquei à batalha de Hastings, travada no sul de Inglaterra no ano de 1066 (no coração da Idade Média 'Central', ou 'Plena', como lhe chamam muitos historiadores). Avaliando a extensão deste meu texto, o leitor dirá que dispensei um tratamento 'de luxo', ou até desproporcionado, a este último caso; assumo isso sem qualquer rebuço: conheço poucos historiadores que não considerem Hastings a batalha mais importante de toda a história medieval europeia. Militarmente, opôs a melhor cavalaria da época (a normanda, chefiada pelo duque Guilherme "o Conquistador") a uma das melhores infantarias de então (a anglo-saxónica, liderada pelo rei inglês Haroldo II Godwinson). Por isso mesmo, o combate foi extremamente renhido, estimando-se que tenha durado cerca de nove ou dez horas, uma relativa anormalidade para os padrões da guerra medieval (ou mesmo do mundo antigo). A batalha é iluminada por um conjunto excecionalmente valioso de fontes, tanto normandas como anglo-saxónicas, entre as quais a melhor peça iconográfica medieval europeia: a Tapeçaria de Bayeux, um 
bordado histórico de valor incalculável produzido em ateliê anglo-saxónico, sob encomenda normanda, pouco depois do evento. E, no entanto, muitos aspetos do combate continuam envoltos num certo mistério, o que torna muito sedutor retomar a sua análise. Por outro lado, politicamente, foi uma batalha que marcou a Europa. A sua pré-história é relevantíssima, pois, para ser bem contada, obriga a evocar a conquista da Bretanha romana pelos Anglo-Saxões (entre os séculos v e viI d. C.) e, várias centúrias mais tarde, a conquista viking da Inglaterra (c. 1013). A história coeva do acontecimento é igualmente apaixonante, pois convida a olhar sobre a fixação dos Normandos (os Nordmen, ou "homens do Norte") em França, sobre a notável expansão do seu ducado e sobre as vicissitudes políticas no reino de Inglaterra ao tempo de Eduardo "o Confessor" (1042-1066), ele próprio um homem formado e parcialmente criado na Normandia. Quanto ao pós-batalha, será de tudo o mais relevante: a conquista normanda mudou substancialmente a Inglaterra e criou um poderoso reino trans-Canal da Mancha, que estaria cerca de um século mais tarde na génese do fabuloso Império Angevino de Henrique II (1154-1189). Com isso, o destino da França - o destino da Europa - foi fortemente afetado, e as consequências diretas desse facto prolongaram-se até ao termo da Guerra dos Cem Anos (em 1453). Pode, aliás, dizer-se que uma parte do que veio a ser a Inglaterra moderna, a Inglaterra dos Tudor, resulta da conquista normanda de 1066. A batalha de Hastings, como raras batalhas em toda a história da Humanidade o conseguiram fazer, mudou a sorte das duas maiores potências económicas e políticas europeias de então, precipitou transformações que só seriam inevitáveis muitas décadas mais tarde e, sobretudo, introduziu mudanças que de outro modo jamais teriam ocorrido. Em 1066, foi a última vez na História que a Inglaterra foi conquistada, mas a marca desse facto permaneceu visível até aos nossos dias.

Espero sinceramente que o meu leitor tenha, ao percorrer este livro, o mesmo prazer que eu tive ao escrevê-lo. Se lhe posso dar um conselho, é o de que não esmoreça perante a quantidade de informações, perante a vasta galeria de personagens e de acontecimentos que este livro lhe dá a conhecer (ou a recordar). Acompanhar e tirar proveito de um bom livro de História não pressupõe memorizar todos os factos, fixar todas as datas: o 
mais importante é seguir o fio da narrativa (de resto, sem quaisquer notas de pé de página e cuidadosamente ilustrada), se necessário voltando episodicamente atrás para recuperar um ou outro pormenor (tal como fazemos, por vezes, na leitura de um romance), confiar na lógica interna da história que nos está a ser contada e na capacidade natural de cada um de nós para reter o principal. Na companhia de heróis como Alexandre Magno, Aníbal Barca, Carlos Martel ou Guilherme "o Conquistador", nenhuma leitura é maçadora, nenhuma narrativa corre o risco de trazer pouco proveito ou de fazer escasso sentido. No final, o leitor verá que aprendeu muitíssimo ao longo desta viagem de catorze séculos e, claro, poderá regressar quando quiser ao tema que lhe deu mais gosto, para o reler e redescobrir.

Quero também expressar aqui o meu sentido agradecimento a todos os que me ajudaram a concretizar este projeto. Na verdade, beneficiei neste trabalho do apoio de uma pequena mas incansável equipa de amigos e conselheiros. Em primeiro lugar, agradeço profundamente ao Dr. José Morais, que convidei para realizar as ilustrações que um livro deste tipo não pode deixar de ter, e a quem devo centenas de horas de trabalho sensível, entusiástico e competente, boa parte dele em parceria com a São Morais, um e outra já amigos meus de longa data e profissionais habituados a responder com qualidade a desafios desta natureza. Agradeço também ao Dr. José Eduardo Braga a revisão amiga e pronta de todos os capítulos, a conversão de muitos nomes estranhos de pessoas, lugares, povos e rios e a tradução de muitos trechos latinos, que utilizo sobretudo no capítulo dedicado à batalha de Hastings (incluindo longas passagens da sua principal fonte: Guilherme de Poitiers, capelão de "o Conquistador"). Ao Doutor Miguel Gomes Martins, (re)conhecido especialista em história militar medieval e excelente companheiro de trabalho, agradeço igualmente a revisão de todos os casos aqui considerados e inúmeras sugestões que valorizaram enormemente o resultado final deste estudo. Ao Prof. Doutor José Ribeiro Ferreira, helenista de grande mérito, e ao Doutor Henrique Modanez de Sant'Anna (bom amigo da Universidade de Brasília), agradeço ainda a revisão cuidadosa do capítulo dedicado à batalha de Gaugamela. Finalmente, à Dra. Maria de Fátima Lopes agradeço a esmerada revisão final de todos os 
meus textos, no sentido de lhes dar maior fluidez e de os adequar à nova ortografia da língua portuguesa.

Desejo ainda exprimir o meu sentido reconhecimento à Comissão Portuguesa de História Militar, na pessoa do seu Presidente, Senhor Tenente-General Alexandre de Sousa Pinto, e ao Centro de História da Sociedade e da Cultura, na figura do seu Coordenador científico, Prof. Doutor João Marinho dos Santos, pelo apoio precioso que concederam a esta edição, permitindo que ela se concretizasse nas condições por mim idealizadas, nomeadamente em matéria de ilustração dos textos, beneficiando com isso um público de estudantes e de outros leitores que pretendemos o mais amplo possível.

Não quero, porém, terminar sem endereçar os meus melhores agradecimentos ao Prof. Doutor Delfim Leão, ilustre Diretor da Imprensa da Universidade de Coimbra, pelo acolhimento dispensado a este projeto. Gostaria de expressar também a minha gratidão à Dra. Maria João Padez de Castro, incansável Diretora-Adjunta da IUC, e ao meu bom e velho amigo António Barros, conceituado diretor de imagem da IUC. Para o Senhor António Resende, que paginou este livro com a dedicação e a competência do costume, o testemunho do meu grande apreço. Devo também ao Senhor Carlos Costa uma infografia cuidadosa da capa e diversas atenções e apoios na hora de fechar as "artes finais" deste trabalho. E à Gráfica de Coimbra, na pessoa do seu Diretor de Produção, Senhor Manuel Gândara, devo não só uma cumplicidade amiga com muitos anos, mas também uma assistência eficaz e competente, que tornou o acompanhamento da edição deste livro um verdadeiro prazer.

À família mais próxima, em especial à Nônô, ao Vasco e ao Jaime, agradeço o apoio, a confiança e o estímulo de todos os dias. Isso é, afinal de contas, o mais importante de tudo.

João Gouveia Monteiro 


\section{CAPÍTULO I}

\section{Gaugamela (331 A. C.): Alexandre MAgnO \\ - CONQUistAR A PÉRSIA E DEPOIS O MUNDO}

\section{Um colosso chamado Alexandre}

Alexandre III, dito "o Grande" ou "Magno", nasceu em Pela (ou em Vergina), na Macedónia, em julho de 356 a. C., sendo filho do rei Filipe II da Macedónia e de Olimpíade do Epiro. De entre os conquistadores do mundo antigo, foi certamente o mais célebre e muitos consideram-no o maior general de todos os tempos. É conhecida a admiração que Napoleão nutria por esse príncipe, que faleceu muito jovem e depois de ter conquistado um império que se estendia da Grécia para oriente, até aos limites do mundo então conhecido, abarcando as atuais Macedónia, uma pequena parte da Sérvia, o Montenegro, o sudeste da Roménia, grande parte da Bulgária, a Grécia, a Turquia, a Síria, o Líbano, a Palestina, Israel, o Egito, o Iraque, o Irão, o Koweit, o Afeganistão, parte do Usbequistão, parte do Azerbaijão, parte do Turquemenistão, parte do Tajiquistão, parte do Quirguistão, o noroeste da Índia e o Paquistão!

A esmagadora maioria destes territórios fazia parte do poderoso Império Persa, que Alexandre conquistou numa única campanha, iniciada na primavera de 334 a. C. e concluída dez anos depois. A história que aqui vamos contar é, portanto, a história de uma grande aventura coletiva feita de sangue, suor e lágrimas e liderada por um jovem general que teve o privilégio de ter tido como mestre (entre os 13 e os 16 anos) o filósofo 
Aristóteles, que trazia sempre consigo uma cópia da Ilíada e que, pelos seus feitos e feitio (propenso a arrebatamentos e a excessos), se pode gabar de ter conquistado o que mais ninguém no mundo conquistou, sem nunca ter sido vencido.

Que fontes temos à nossa disposição para reconstituir a odisseia daquele que foi um dos últimos generais do mundo antigo a comandar, na linha da frente, o seu exército, expondo-se a todo o tipo de perigos e acabando por ser ferido por quase todo o tipo de armas? Trata-se de fontes tardias, pois os relatos coevos perderam-se na noite dos tempos. O guia mais fiável é Lúcio Flávio Arriano, um cidadão romano de língua grega nascido em Nicomédia entre 85 e 90 d. C. e que serviu no exército romano durante as guerras do imperador Trajano no Oriente. Mais tarde, já no principado de Adriano (117-138), Arriano foi governador da Bética e cônsul; serviu depois como governador da província da Capadócia, onde repeliu uma invasão dos Alanos, tendo até composto o tratado Disposição de marcha e ordem de batalha contra os Alanos, dedicado talvez ao imperador Antonino Pio; no final da sua carreira, Arriano retirou-se para Atenas, onde chegou a ser arconte (alto magistrado), tendo falecido por volta de 165. A sua obra principal, Anabasis Alexandri ("a marcha de Alexandre pela terra adentro"), é a fonte mais completa e verosímil para o estudo das campanhas do conquistador macedónico. O relato principia em 335 a. C. e apresenta uma característica preciosa: a reconstituição das principais operações militares (incluindo a batalha de Gaugamela) baseia-se em larga medida nos relatos de Ptolomeu, um dos principais generais de Alexandre e futuro rei do Egito. Ptolomeu era um homem entendido em assuntos militares e parece ter escrito uma espécie de diário dos acontecimentos em que interveio, ao lado de Alexandre! Uma outra fonte, hoje perdida mas ainda acessível a Arriano, é Aristobulo, um especialista grego que integrava o séquito de Alexandre. Ao que parece, Aristobulo passou para o seu diário um documento do comando persa contendo a ordem de batalha do exército de Dario III em Gaugamela, documento esse que terá caído em seu poder depois do combate.

As outras fontes principais são: Diodoro da Sicília, um grego siciliano que escreveu, no terceiro quartel do séc. I a. C., uma História Universal onde se inclui um amplo relato, algo sensacionalista, do reinado de Alexandre; Quinto Cúrcio, um retórico profissional que viveu em Roma, onde foi sena- 
dor e cônsul, entre c. 10 a. C. e 53 d. C., tendo desempenhado também as funções de governador militar da Germânia Superior e de África; e Plutarco, o célebre filósofo e biógrafo grego, autor de Vidas Paralelas, onde o retrato de Alexandre emparelha com o de Júlio César, mas numa perspetiva mais apologética e com a intenção de construir um modelo de fundo moral.

O sucesso de Alexandre não ficou a dever-se apenas à sua capacidade de liderança e de comando militar. Ele deve muito a seu pai, de quem herdou, não apenas o trono, mas também um exército experiente, com provas dadas, e que continha em si tudo o que era preciso para se tornar uma poderosa máquina de guerra. Ora, o formidável exército de Filipe II era uma tapeçaria feita de vários fios, entrecruzados de forma magistral. Por um lado, ele acolhia a tradição militar dos hoplitas gregos, os soldados de infantaria que combatiam em formações cerradas, 'varrendo' os adversários que lhes surgiam pela frente. Por outro, completava o recurso a essa infantaria (que aliás Filipe modificou bastante) com o uso de cavalaria, a qual se revelaria indispensável nas manobras atacantes. Esta utilização da cavalaria deve ser, por sua vez, relacionada com a tradição militar oriental, em especial com a que se desenvolveu na região do Crescente Fértil desde a época dos Egípcios e dos Assírios e que os Persas, ao tornarem-se senhores do Oriente após as conquistas de Ciro "o Grande" (559-530 a. C.), de Cambises II (530-522 a. C.) e de Dario I (521-486 a. C.), acabariam por assimilar.

Fora do quadro desta dupla influência (hoplitas gregos e cavalaria oriental), é difícil compreender o exército que Alexandre Magno herdou do seu pai em 336 a. C. e a que imprimiria depois a sua marca pessoal, tornando-o então, definitivamente, uma verdadeira máquina de conquistar o mundo.

\section{A falange hoplita e a arte militar grega}

Por influência dos Poemas Homéricos, a tradição associa à Grécia dos inícios do período arcaico (sécs. VIII-VI a. C.) um estilo de guerra baseado nos duelos protagonizados por heróis armados de uma lança de arremesso (ex.: Aquiles contra Heitor). É discutível se isto alguma vez correspondeu à verdade, mas do que não há dúvida é de que, no séc. viI, o panorama já 
não era esse. Por volta de 650 a. C., temos já representações e referências literárias seguras à falange hoplita, que poderá, portanto, ter surgido algumas décadas antes. Tratava-se de uma infantaria de linha equipada com elmo cerrado (o 'elmo coríntio'), com peitoral ou corselete e com grevas, tudo em bronze, e munida de um escudo, de uma lança de choque (e já não de arremesso) e de uma espada para o corpo a corpo. A peça de referência era o escudo (boplon), que deu nome a este tipo de guerreiro. Era uma peça redonda e convexa, com 80 a $90 \mathrm{~cm}$ de diâmetro, fabricada em madeira ou em couro enrijecido, com revestimento de ferro, uma aresta metálica e dupla pega: uma embraçadeira central para se enfiar o braço esquerdo até ao cotovelo, e uma pega de mão junto à orla do escudo.

Os hoplitas (cf. J. Lazenby) eram cidadãos com riqueza suficiente para adquirirem o seu equipamento militar (que, com o tempo, tenderá a aligeirar-se), circunstância que lhes garantia o estatuto de homens livres e, portanto, o direito a votar para eleger os magistrados e aprovar as leis. O desenvolvimento do comércio e o início do movimento colonial grego devem ter aumentado o número de homens capazes de se autoequiparem e de comparecerem na linha de batalha. Muitos deles eram proprietários rurais que detinham terrenos com poucos hectares, gente ciosa dos seus bens e dos direitos cívicos que lhes estavam associados.

O modelo de organização sociopolítica que se desenvolveu na Grécia antiga foi o da polis, a cidade-estado. Os cidadãos eram iguais perante a lei e a defesa do território constituía uma obrigação relevante. Ora, isto transparecia claramente no tipo de guerra protagonizado pelos hoplitas: centenas ou milhares de cidadãos-combatentes eram alinhados em falanges cerradas com uma frente e uma profundidade variáveis (geralmente 8, 12 ou 16 fileiras de fundo, mas podendo ser mais). Como a Grécia é uma região montanhosa, pouco propícia à criação de cavalos (a não ser da Beócia para norte: na Tessália ou na Macedónia), e porque é uma região pedregosa (ingrata para os animais numa altura em que não se inventara ainda a ferradura), a guerra dos hoplitas era uma guerra travada a pé. Lado a lado, ombro a ombro, os soldados-cidadãos partilhavam o mesmo destino, dando - como observou F. Adcock - expressão militar à solidariedade comunitária, que era a essência da cidade-estado grega. 
A guerra deixara de ser uma oportunidade para exibições individuais; agora, tratava-se de garantir a coesão do conjunto e de assegurar a vitória de uma causa comum: a da cidade. Para tanto, buscava-se um terreno plano e tentava-se, num único combate apeado, obter uma sentença de guerra cujo veredito era aceite por todos e podia conduzir à paz ou à celebração de uma trégua. Tudo rápido, tudo intenso, tudo muito disciplinado, uma luta entre iguais (como o ideal olímpico defendia) visando uma decisão breve e inequívoca, se possível duradoura, pois as colheitas aguardavam os soldados e urgia regressar à vida normal com um mínimo de prejuízo. Em caso de vitória, este regresso podia assumir a forma de uma marcha triunfal até à cidade de origem, com aclamação à chegada. Como resumiu V. D. Hanson, "a escolha da resposta militar para a vitória ou proteção de territórios, com a ascensão da polis, foi um padrão cívico, materializado na utilização constante de infantaria pesada armada".

Quando - completados os sacrifícios rituais, uma refeição ligeira com vinho e as exortações dos comandantes - avançavam uma contra a outra (em alguns casos mais lentamente, ao som das flautas, noutros em passo mais acelerado), as falanges hoplitas lançavam os seus gritos de guerra (a que Aristófanes chamou um eleleu ululante) e, depois, chocavam entre si de uma forma violenta. Ao contacto dos escudos dos soldados da primeira fila sucedia-se o manejo das lanças, com 2 a 2,5 m de comprimento e brandidas com o braço direito erguido, golpeando de cima para baixo. Quando se descortinava uma aberta entre os escudos inimigos, visava-se a garganta ou os ombros de um dos soldados em frente: "a sorte em movimento", como lhe chamou J. Keegan. Caso se abrisse uma brecha na formação adversária, tentava-se alargá-la, contando com a pressão das filas mais recuadas (que também iam fornecendo efetivos para suprir as baixas) e sacando das espadas para atacar as pernas e o abdómen dos inimigos.

Neste jogo de empurrões (o othismos), a falange mais forte acabava por pôr em fuga a formação adversária e, depois, tentava 'enrolar' os restantes contingentes inimigos dispostos no terreno (um dos significados para o termo grego "falange" é, justamente, o de "rolo"). As baixas entre os vencidos eram elevadas (c. 15\%, muitas delas por perfuração intestinal), embora as 
perseguições fossem curtas e não se visasse a aniquilação dos adversários, até porque se tratava muitas vezes de alargar o quadro de alianças políticas ou económicas entre cidades.

Convém acrescentar que o instinto de autodefesa dos hoplitas tendia a deslocar a marcha da falange para o flanco direito, uma vez que a vida de cada soldado dependia da proteção que o escudo do camarada à sua direita lhe garantia (o boplon resguardava quase só a parte esquerda do corpo). Justamente por isso, o combate tendia a estar dominado por um movimento de rotação sobre um eixo invisível, sempre sobre o lado direito e superior à vontade das partes. Alguns comandantes tiraram bom partido desse facto, ao reforçarem, logo à partida, a composição do seu flanco direito.

Nas batalhas dos hoplitas, havia pouco lugar para a cavalaria. Não só porque a disponibilidade de montadas era muito escassa, mas também porque o estribo ainda não tinha sido inventado, pelo que a capacidade de choque dos cavaleiros era mais reduzida, raramente conseguindo romper a falange cerrada de lanças (é curiosa a afinidade semântica entre a "falange hoplita" e a "falange anatómica": os dedos saindo em paralelo de um corpo central, tal como se fossem lanças). Quanto a tropas ligeiras (arqueiros, fundibulários, dardeiros), embora sempre presentes, e às vezes em grande número, raramente eram decisivas: para tirar partido dos seus mísseis (que tinham alcances reduzidos: menos de $20 \mathrm{~m}$ com um dardo, até 90 ou $100 \mathrm{~m}$ com um arco ou uma funda), os atiradores precisavam de espaço e isso não abundava numa falange hoplita...

O ponto fraco das formações hoplitas era a defesa dos seus flancos, onde alguma cavalaria experiente podia causar embaraços e onde atiradores exímios conseguiam causar vítimas, caso a falange não estivesse atenta e agrupada e os hoplitas pudessem ser apanhados isoladamente ou em pequenos grupos. Tenhamos presente que não se tratava de exércitos profissionais e com capacidade para manobrar. Com uma exceção: Esparta. Esta cidade dispôs de um exército menos amador, apto a executar manobras básicas no campo de batalha (transição da ordem de marcha para a ordem de combate, reforço momentâneo de um dos flancos, reorientação da frente, reagrupamento após um primeiro revés) e, por isso, dominou o cenário militar grego até c. 370 a. C. A falange espartana era de tal modo temida 
que, por vezes, os seus adversários fugiam do campo de batalha antes do choque, dando origem às chamadas "batalhas sem lágrimas".

Esparta treinava as suas crianças desde muito cedo para a guerra e tinha um modelo de desenvolvimento diferente do de Atenas (mais virada para a construção de um império comercial); isso permitia-lhe apresentar exércitos com várias subunidades (p. ex., o enomotia, de 32 homens, ou o pentekostys, com 128). Estes contingentes (assim como outros maiores, como o mora, com 1280 homens), cada qual com o seu comandante, agilizavam a capacidade de manobra dos Espartanos. No combate de Nemeia, em 394 a. C., onde defrontaram uma coligação de forças da Beócia, de Corinto, de Argos, de Atenas e de Eubeia, os Espartanos executaram uma rotação para a direita que lhes permitiu apanhar o adversário no seu flanco mais fraco (o esquerdo) e 'enrolá-lo' depois, como um tapete, unidade a unidade...

A guerra hoplita era uma guerra travada entre cidades-estado gregas. No entanto, quando, em 499 a. C., as cidades gregas da Iónia (na costa oeste da Ásia Menor) se revoltaram contra a dominação persa, o cenário mudou de figura. O Grande Rei da Pérsia, Dario I, sufocou a revolta, mas decidiu castigar Atenas e Erétria, que tinham apoiado a sublevação (ajudando a incendiar Sardes, a capital da Lídia). Assim nasceram as Guerras Pérsicas (ou Medo-Persas), logo marcadas pela batalha travada na planície de Maratona, em 490 a. C., onde os Persas foram derrotados por uma coligação composta por hoplitas de Atenas e de Plateias, liderada por Milcíades. Dez anos depois, o novo rei persa (Xerxes I: 485-465 a. C.) insistiu na guerra contra os Gregos, cuja 'aliança patriótica' se tinha entretanto alargado. No desfiladeiro das Termópilas (em 480 a. C.), os Espartanos do rei Leónidas, com o apoio dos Atenienses, barraram o avanço dos Persas até serem atacados pela retaguarda; embora chacinados, deram tempo à população de Atenas para se refugiar na ilha de Salamina, onde Temístocles acabaria por destruir metade da frota persa. No ano seguinte (479 a. C.), em Plateias, o comandante espartano Pausânias, sustentado por uma vasta coligação de cidades gregas, conseguiu uma vitória decisiva sobre Mardónio (o general persa que contava com o apoio de Beócios, incluindo Tebanos), complementada com a vitória naval de Mícale, no Egeu oriental, no mesmo ano. 


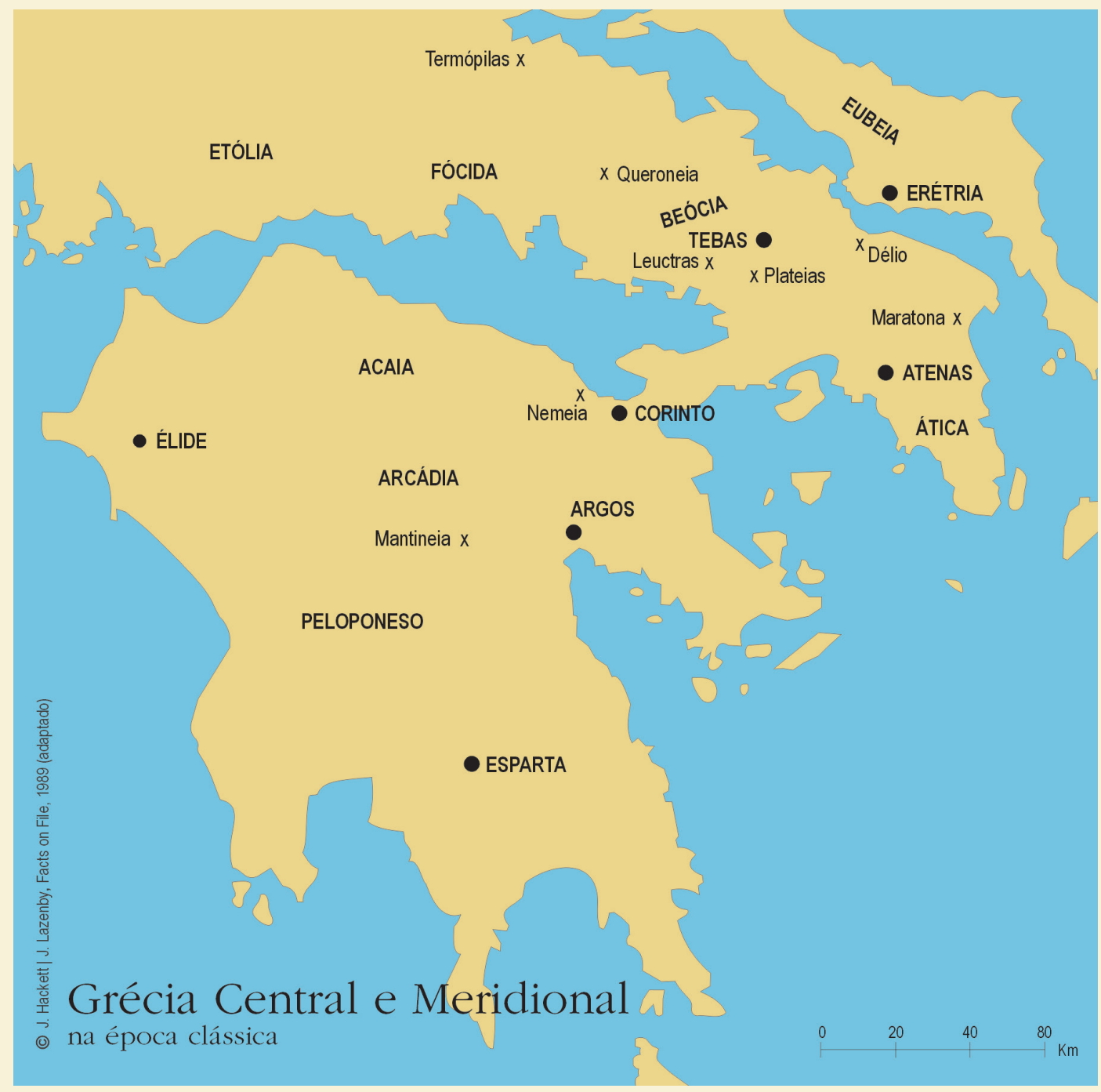


Ora, nas Guerras Pérsicas, a arte militar hoplita teve de fazer face a um inimigo que usava a cavalaria, que recorria a corpos de infantaria ligeira e que tinha uma marinha poderosa! O mínimo que se pode dizer é que os hoplitas superaram o teste com distinção: aprenderam a suportar o tiro cerrado dos arqueiros (Plateias) ou a evitá-lo com movimentos e fugas simuladas (Termópilas); mostraram à cavalaria adversária que não era fácil romper formações cerradas de infantaria pesada (Plateias e Termópilas); souberam usar manobras ínvias de desinformação para atrair os adversários para combates navais em águas confinadas (Salamina); e aprenderam a ajustar o 'tempo certo' de lançamento dos seus ataques (Maratona e Plateias), levando Mardónio a queixar-se da "loucura destrutiva" dos hoplitas (cf. Heródoto). Por isso, após as primeiras Guerras Pérsicas, a falange hoplita continuava rainha dos campos de batalha!

Entretanto, a guerra não abrandava. Entre 460 e 454 a. C., Atenas, encabeçando a Liga de Delos*, que não incluía Esparta e aliados, liderou a guerra contra a Pérsia de Artaxerxes I (465-424 a. C.) pela posse do Egito. Cerca de 449 a. C., por esgotamento de ambas as partes, foi assinada a Paz de Cálias, em cujos termos os Atenienses se comprometiam a não enviar mais expedições a território persa, ao passo que o rei persa não deveria mandar o seu exército para além do rio Hális, nem a sua frota para lá da Lícia (na Ásia Menor); nos termos deste acordo, os sátrapas (governadores persas) das províncias ocidentais ficariam responsáveis pela sua própria defesa e o exército do Grande Rei só interviria se a paz fosse quebrada.

No entanto, pouco depois, novas guerras, desta feita internas, voltaram a dilacerar a Grécia, com Atenas (devido aos excessos do seu domínio estratégico e comercial) a suscitar a animosidade de Corinto, de Tebas, de Esparta e de várias outras poleis; isso conduziria à célebre Guerra do Peloponeso (431-404 a. C.), de que Tucídides nos deixou um relato formidável.

\footnotetext{
* Utilizaremos neste texto o termo "Liga" por hábito e comodidade de discurso e de comunicação, mas tendo presente que o leitor deverá saber distinguir entre, por um lado, uma aliança puramente militar (ou "Simaquia"), como a Liga do Peloponeso, a Liga de Delos ou a Liga de Corinto, e, por outro, uma aliança de tipo federativo (ou "Simpolitia"), como a Liga da Etólia ou a Liga Aqueia (ou da Acaia), entre outras. Sobre esta matéria, veja-se J. Ribeiro Ferreira, 2004 e 2010.
} 
A Atenas de Péricles (falecido em 429 a. C.) acabou por perder esta guerra, mas convém lembrar que isso se deveu à intervenção da Pérsia e da sua poderosa marinha, a quem Esparta, abandonando a sua posição patriótica de outrora, havia apelado... Também o fracasso da expedição à Sicília, em 415-413 a. C., proposta por um dotado mas ambicioso Alcibíades, prejudicou seriamente os planos atenienses.

Ao longo das décadas seguintes, a guerra reacendeu-se, e em várias ocasiões com intervenção dos Persas. Isso foi facilitado pelo apoio de Esparta a Ciro "o Jovem", o príncipe persa que conspirou contra o seu régio irmão Artaxerxes II e que acabou morto na batalha de Cunaxa, em 401 a. C. Tal apoio levou o rei persa a quebrar a Paz de Cálias. Em 396, o sátrapa Farnabazo derrotou o rei espartano Agesilau. Diversas cidades gregas, como Atenas, Tebas, Corinto e Argos, aproveitaram este ambiente para se aliarem à Pérsia contra Esparta, devido ao domínio unilateral exercido pelos Espartanos nos anos que se seguiram à Guerra do Peloponeso. Isto levou à Guerra de Corinto, entre 395 e 387 a. C., no decurso da qual Atenienses, Persas e Cipriotas, coligados, destruíram a marinha espartana (batalha naval de Gnido, em 394 a. C.). Porém, nessa altura, os Persas temeram o ressurgimento do poder ateniense e acabaram por ir, sub-repticiamente, em auxílio dos Espartanos... O impasse só se resolveu em 387 a. C., com a Paz de Antálcidas (nome de um general espartano), que determinou que a Pérsia controlaria as cidades da Iónia e que as demais cidades gregas seriam independentes, cabendo a Esparta garantir a paz. A partir dessa altura, a diplomacia persa, satisfeita com o resultado obtido, estimulou a paz na Grécia de modo a preservar o equilíbrio de poderes nesta região, que aliás lhe interessava como fonte de recrutamento de mercenários. Na Grécia, porém, os equilíbrios eram frágeis, as ambições eram muitas e as guerras intestinas continuavam, nomeadamente entre Esparta e a sua agora grande rival em terra: a cidade de Tebas. O séc. IV prometia, portanto, ser ainda mais animado do que a centúria anterior!

É claro que toda esta atividade bélica teve repercussões militares relevantes, desde o reforço do sistema logístico (ex.: o abastecimento marítimo) até uma atitude estratégica mais ofensiva, passando por diversas inovações 
táticas. Se a infantaria pesada continuou a dominar nos campos de batalha, ela percebeu que, definitivamente, já não estava sozinha. A infantaria ligeira (fundibulários de Rodes, arqueiros de Creta) crescera e o seu papel fora reforçado, nomeadamente com o uso generalizado dos ágeis "peltastas", muitos deles originários da Trácia (na atual Bulgária) e equipados com um escudo leve (pelte) e com uma lança que tanto podia ser usada para arremessar, como se fosse um dardo, quanto para estocar.

O emprego desta infantaria ligeira está também relacionado com a crescente utilização de mercenários gregos. O general ateniense Ifícrates e o espartano Brásidas notabilizaram-se, nos finais do séc. v e nos inícios do séc. IV a. C., por terem sabido tirar partido deste tipo de combatentes. A guerra começava a ganhar um estatuto mais profissional e a relação direta entre 'disciplina' e 'ideal cívico' começava a esbater-se. O esprit de corps tinha agora uma outra motivação, mais contratual e menos política, ideológica ou afetiva. Servia-se mais longe, por mais tempo (já não havia que regressar aos trabalhos agrícolas) e em qualquer altura do ano. Por outro lado, as tropas montadas começaram a ter um papel mais importante, sendo utilizadas não apenas para cortar abastecimentos, garantir retiradas em segurança ou fustigar colunas inimigas (através, p. ex., de arqueiros montados), mas também, pontualmente, para manobras de flanqueamento capazes de provocar dificuldades à velha falange hoplita.

Por fim, a própria forma de atuar da infantaria pesada conheceu inovações luminosas. Isso verificou-se, sobretudo, no âmbito das guerras entre Tebas e Esparta, no segundo quartel do séc. IV a. C. Em Leuctras, em 371 a. C., o general tebano Epaminondas, em clara desvantagem numérica, optou por formar uma coluna que incluía os seus melhores homens (o Batalhão Sagrado) numa profundidade de 50 fileiras (!) e por posicioná-la (contrariamente à tradição) no flanco esquerdo, ao qual caberia entrar em contacto com o setor mais forte do adversário. Depois, aumentou a potência da marcha e avançou numa disposição oblíqua, atrasando a sua ala direita e evitando assim o choque simultâneo em toda a linha da frente. Enquanto isso, tropas montadas tebanas perturbavam a falange espartana nos flancos.

O resultado foi espetacular e inspirou quem amava o estudo da arte da guerra. Entre estes, estava o futuro Filipe II da Macedónia, que na dé- 
cada de 360 a. C. viveu alguns anos como refém em Tebas... Em Mantineia, no ano de 362 a. C., deu-se uma nova vitória tebana sobre os Espartanos. Infelizmente, foi o último combate de Epaminondas, que ali encontrou a morte. A 'revolução' tinha os seus riscos, mas, ainda assim, o desafio era irresistível. Leuctras mostrou que a velha arte militar hoplita, pouco sofisticada do ponto de vista tático (pois assentava num "duelo de massas" em campo raso, como observou Adcock), podia ser renovada. Ao servir-se, num movimento oblíquo, da sua máxima força para atacar o ponto nuclear da linha adversária e esmagar a "cabeça da serpente" inimiga (A. Ferrill), Epaminondas tocara na essência da tática militar e inaugurara uma nova era!

\section{A tradição militar do Médio Oriente e o exército persa}

Ao contrário do que se pensa, a guerra já tinha alcançado na Pré-História um nível razoável de organização. Já nessa época reconhecemos indícios do emprego de ataques em linha, de colunas de marcha, de fortificações defensivas ou mesmo de armas de curto e de médio alcance. No Paleolítico, a guerra evoluiu da luta contra os animais para a luta contra os homens e, durante o Neolítico, novas armas (como o arco e a flecha) vieram duplicar a capacidade de arremesso da lança (cf. A. Ferrill).

As principais civilizações pré-clássicas do Crescente Fértil, nas proximidades do rio Nilo, recolheram essa herança e trataram de a aperfeiçoar. Os Egípcios já tinham exércitos de tipo profissional, que incluíam tropas estrangeiras (como beduínos, núbios e outros). No tempo dos Hicsos (entre 1640 e 1550 a. C.), o militarismo egípcio traduzia-se num armamento diferenciado, no recurso a fortificações e na utilização de carros de guerra, a principal arma de choque. Um faraó da XVIII dinastia, Tutmés III (c. 1479-1425 a. C.), ficou célebre pelas suas 17 campanhas militares, que visaram impor a hegemonia egípcia em territórios como a Síria, a Palestina ou a Fenícia. Ao tempo do Império Novo (fundado por Ahmés, c. 1550 a. C.), o exército dos faraós continha já divisões com autonomia tática, compostas por 5000 homens (entre infantaria e carros de guerra) e subdivididas em 20 companhias de 250 elementos. A logística progrediu bastante, ao ponto de ser possível deslocar eficazmente tropas ao longo das fronteiras. 
Coube, entre outros, aos Assírios desenvolver este potencial bélico. Durante mais de um século, eles tentaram impor o seu domínio sobre o Próximo Oriente, sem nunca o conseguirem totalmente. Num triângulo delimitado pelas montanhas de Urartu (na Arménia), Babilónia e Israel, os Assírios desenvolveram operações que envolviam tropas do exército real a cavalo e foram os primeiros a utilizar unidades regulares de cavalaria (embora apenas como elite das tropas de choque). Tais grupos compensavam as limitações dos carros de guerra (que só podiam atuar em terrenos planos) e sabemos que existia um oficial (o musarkisu) encarregado do aprovisionamento de cavalos. Outra vertente em que os Assírios se destacaram, em especial com o seu rei Tiglate-Pileser III (745-727 a. C.), foi a guerra de cerco: as técnicas incluíam formas sofisticadas de ataque às muralhas, como o recurso a aríetes de vaivém e a torres móveis protegidas por couros, além de escadas de assalto. A par dos carros de guerra, os Assírios usavam, embora em menor grau, tropas de arqueiros (algumas delas montadas).

Em 612 a. C., a queda da cidade bíblica de Nínive às mãos de uma força de Babilónios, de Medos e de tribos do norte deu início à desagregação do Império Assírio, acentuada dois anos mais tarde com a perda de Haran. Em 609 a. C., com a derrota de Assurbalit, o Império ruiu de vez. Iniciou-se então o período neobabilónico, com alguma repartição de poderes no Médio Oriente mas com supremacia dos Medos. Porém, em 550 a. C., Ciro II (dito "o Grande"), príncipe da Pérsia, derrubou o rei dos Medos e iniciou uma série de conquistas a ocidente, que incluiriam a Lídia e a Babilónia.

O exército persa (cf. N. Secunda) estava então baseado numa infantaria ligeira adestrada no uso do arco e da funda e muita dela munida de um escudo chamado spara: uma peça retangular grande, de couro espesso enrijecido com vimes, muito leve e resistente. Os sparabara atuavam frequentemente em combinação com os arqueiros, que dominavam na Mesopotâmia. Neste sentido, existiu alguma continuidade entre as tradições militares assíria e persa.

A máquina de guerra persa estava estruturada em unidades que correspondiam a múltiplos de 10 , cada qual com o seu comandante: brigadas de 10 homens (dathabam), batalhões de 100 (satabam), regimentos de 
1000 (hazaraban) e divisões de 10000 (baivarabam, a que os Gregos chamavam "miríade"). A subunidade básica era o dathabam e os seus homens eram dispostos em fileira no campo de batalha, com o comandante à frente, munido do spara e, muitas vezes, de uma lança curta (c. 1,80 m), seguindo-se, atrás dele, em nove filas, os restantes soldados da brigada, munidos de arco e de cimitarra (uma espada larga e curva, com o gume no lado convexo). Por vezes, todo o dathabam possuía um arco e o escudo grande era usado como muralha na linha da frente, de modo a permitir o tiro a partir de trás.

A miríade mais importante era a divisão da Guarda Pessoal do Rei: os 10000 Imortais, que retiravam o seu nome, segundo Heródoto, do facto de o seu número ser mantido sempre atualizado. No seu seio, havia ainda uma elite de "lanceiros do rei" formada pelos Persas de condição social mais elevada (os nobres, ou "iguais"). Como o serviço militar era obrigatório entre os 20 e os 24 anos, pode dizer-se que o corpo dos Imortais constituía a nata da recruta persa.

Ao tempo de Ciro "o Grande”, a maior lacuna do exército persa era a cavalaria. Daí as suas dificuldades em conquistar a Lídia, terra de grandes cavaleiros, em 546 a. C. (a tradição diz que só os venceu porque os camelos do seu trem de apoio assustaram os cavalos lídios!). Para além do 'núcleo duro' composto pela infantaria persa, o exército de Ciro tinha sobretudo alguns corpos de infantaria auxiliar fornecidos por povos conquistados ou aliados e por pequenos contingentes de cavalaria das nações onde existia esta tradição (em especial os Medos, que passam por ter sido os melhores cavaleiros do Oriente antigo). Após a conquista da Babilónia, Ciro, receoso de conspirações entre os Medos e as tribos iranianas, decidiu criar uma força de cavalaria persa. Os seus sucessos a ocidente (p. ex., na Lídia) tinham-lhe proporcionado montadas e riquezas para distribuir entre os nobres persas, doravante obrigados pelo seu rei a circular sempre a cavalo... Assim nasceram os 15000 Huvaka, ou seja, os cavaleiros da Casa Real, colhidos no seio da alta nobreza da Pérsia e de entre os quais se apurava ainda uma elite de 1000 cavaleiros em que o Grande Rei depositava especial confiança. A nobreza persa importou então algum vestuário típico dos Medos (calças, túnica de manga comprida descendo até ao joelho, capote 


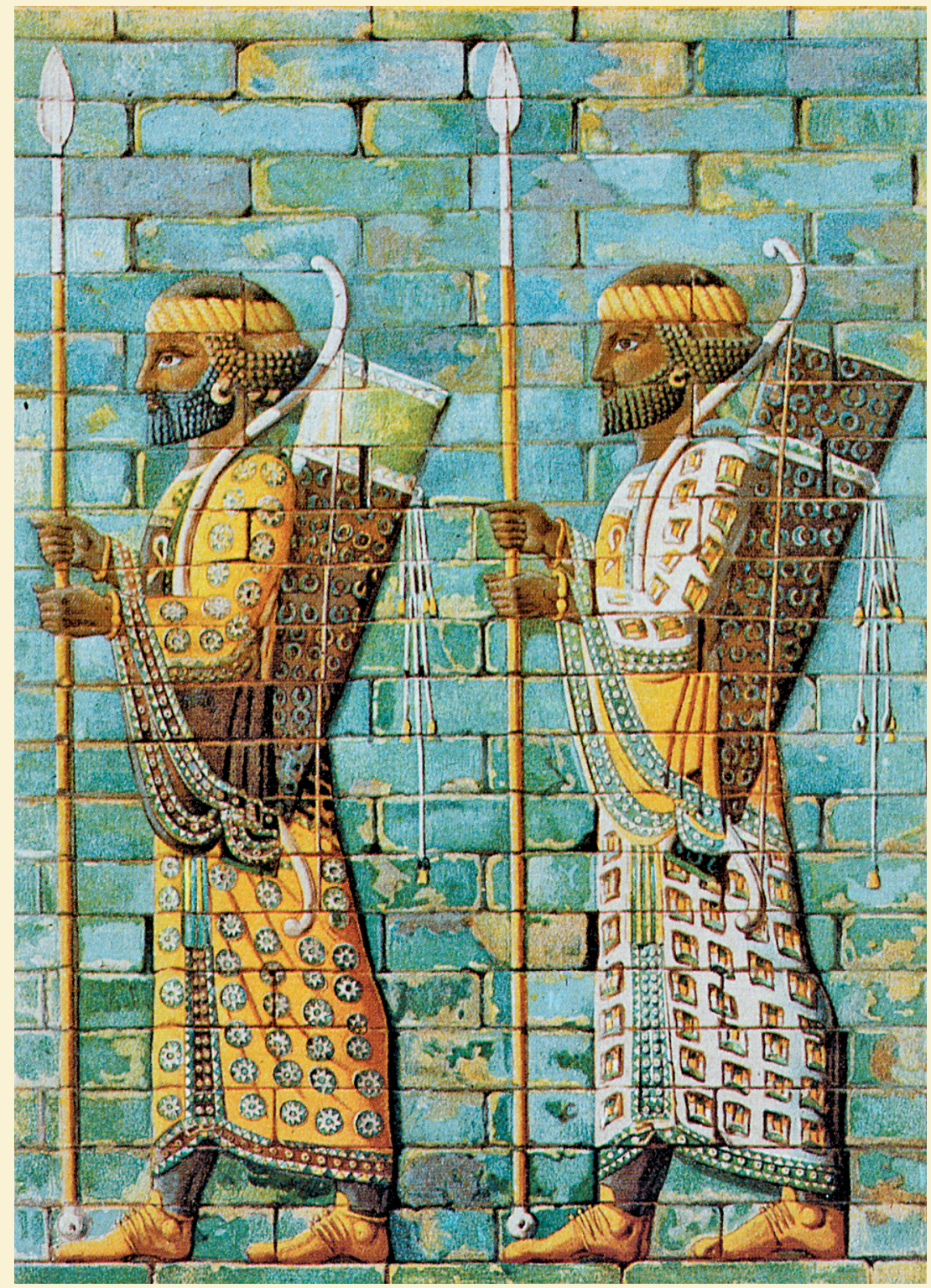

Pintura policromática em suporte de tijolo, do palácio real de Susa (Pérsia). Representa dois guardas de regimentos diferentes dos Imortais, armados de lança e de arco. Museu Nacional do Louvre, Paris (reproduzido a partir de pintura do séc. XIX, de Saint-Elme Gauthier). 
com mangas preso nos ombros, entre outras peças), mas faltava-lhe ainda experiência no combate a cavalo. Daí as dificuldades de Ciro nas lutas contra as tribos da Bactriana (no atual Afeganistão) e contra os Sacas (um povo da Cítia, a nordeste do Mar Negro). Por ironia do destino, o próprio Ciro morreu numa escaramuça menor de cavaleiros, em 530 a. C., contra uma tribo bactriana rebelde...

Esta foi a deixa para a entrada em cena de Cambises II, a quem coube a organização da frota persa que conquistou o Egito e que viria a atuar nas Guerras Pérsicas. A morte prematura de Cambises gerou um período de confusão de que se aproveitou um pequeno grupo de nobres, um dos quais viria a subir ao trono sob o nome de Dario I (521-486 a. C.). Depois de 19 batalhas e da captura de nove reis rebeldes, Dario I lançou-se num programa que haveria de levar o Império Persa à sua máxima extensão: 20 províncias, o que exigia uma logística sofisticada! As campanhas de Dario I na Ásia central geraram recursos humanos que permitiram a contratação de mercenários, facto que ajudaria à transformação do exército persa. Em 515 a. C., Dario estendeu a fronteira do Império Persa até ao rio Indo, posto o que se virou para o ocidente, tentando dominar os Citas no decurso de uma mal sucedida campanha, empreendida em 513 a. C.

Devido a este fracasso, Dario I decidiu reorganizar o seu exército, mas poucos anos depois as cidades da Iónia revoltaram-se. Como já referimos, Dario esmagou a rebelião, mas mais tarde decidiu castigar a Grécia. Em 490 a. C., a frota persa aportou em Eubeia e arrasou Erétria. Logo a seguir, uma miríade de Medos, reforçada por infantaria persa e saca e por cavalaria, desembarcou em território ateniense e acampou na planície de Maratona. Porém, os Atenienses e os seus aliados de Plateias saíram vencedores. Dez anos mais tarde, Xerxes I fracassaria em Plateias (479 a. C.), numa batalha que provou a incapacidade da cavalaria persa para atuar como arma de choque, em sistema de carga direta. Contra as falanges hoplitas, os Persas recorreram a arqueiros montados, com unidades de sparabara a apoiar a cavalaria e a crivar de flechas os contingentes gregos que quisessem retirar antes dos ataques da cavalaria. Porém, a cerrada falange hoplita era difícil de repelir e, quando chegou a hora do contacto direto entre as linhas de infantaria, a parede formada pelos sparabara cedeu. Com lanças mais curtas do que 
as dos hoplitas, as primeiras linhas persas viram-se em grande dificuldade; alguns poisaram os arcos e enfrentaram os Gregos individualmente, ou em grupos de dez; e, quando tudo o mais falhou, chegaram a lutar só com as mãos, tentando quebrar as lanças dos hoplitas! No final, acabaram por soçobrar, com a cavalaria persa a conseguir cobrir a sua retirada, o que revela já algum treino e disciplina.

Batalhas como a de Plateias puseram em causa as táticas e o equipamento dos Persas. Logo a seguir, a batalha de Mícale (479 a. C.) confirmou a lição: os sparabara formavam uma barreira esforçada, mas, quando esta quebrava, tudo o resto ruía. Mais do que de armas ofensivas novas, a infantaria persa carecia de um escudo capaz de enfrentar as lanças dos hoplitas. Como explica N. Secunda (in Sir J. Hackett), alguns vasos gregos e pedras de gema persas mostram guerreiros com capas enroladas à volta do braço esquerdo, à maneira de escudo! Será preciso esperar até c. 460 a. C. para encontrarmos arqueiros persas munidos de bons escudos: de madeira ou de couro, em forma de crescente, com uma aresta metálica e com um corte no bordo superior para facilitar a visão ao arqueiro. Estas peças lembram o pelte dos peltastas trácios e gregos, mas são muito mais largas, tendo recebido o nome de taka.

Segundo Xenofonte (c. 425-355 a. C.), ao fundar as primeiras satrapias (governos provinciais), Ciro "o Grande" terá ordenado aos sátrapas que tivessem sempre à sua disposição um regimento de lanceiros de elite, tal como aquele que o Grande Rei recrutava no seio dos Imortais. Nos sécs. VI e v a. C., parece que estas tropas eram compostas sobretudo por Persas, mas depois tenderam a ser substituídas por tropas nativas, recrutadas localmente. Na Arménia, talvez isto tenha dado origem aos Melophoroi, uma tropa de infantaria pesada derivada da antiga sparabara real persa e que era mantida pelo rei arménio atuando como sátrapa para o exército persa; tropa de elite, muito bem treinada, equipada com uma lança curta apresentando na conteira (topo traseiro) um contrapeso de prata ou de ouro em forma de maçã, o que explica a designação de Melophoroi (melon, em grego, significa "maçã").

Entretanto, os sátrapas também recrutavam cavalaria pesada no seio da nobreza persa da sua região e reforçavam-na com mercenários de recruta- 


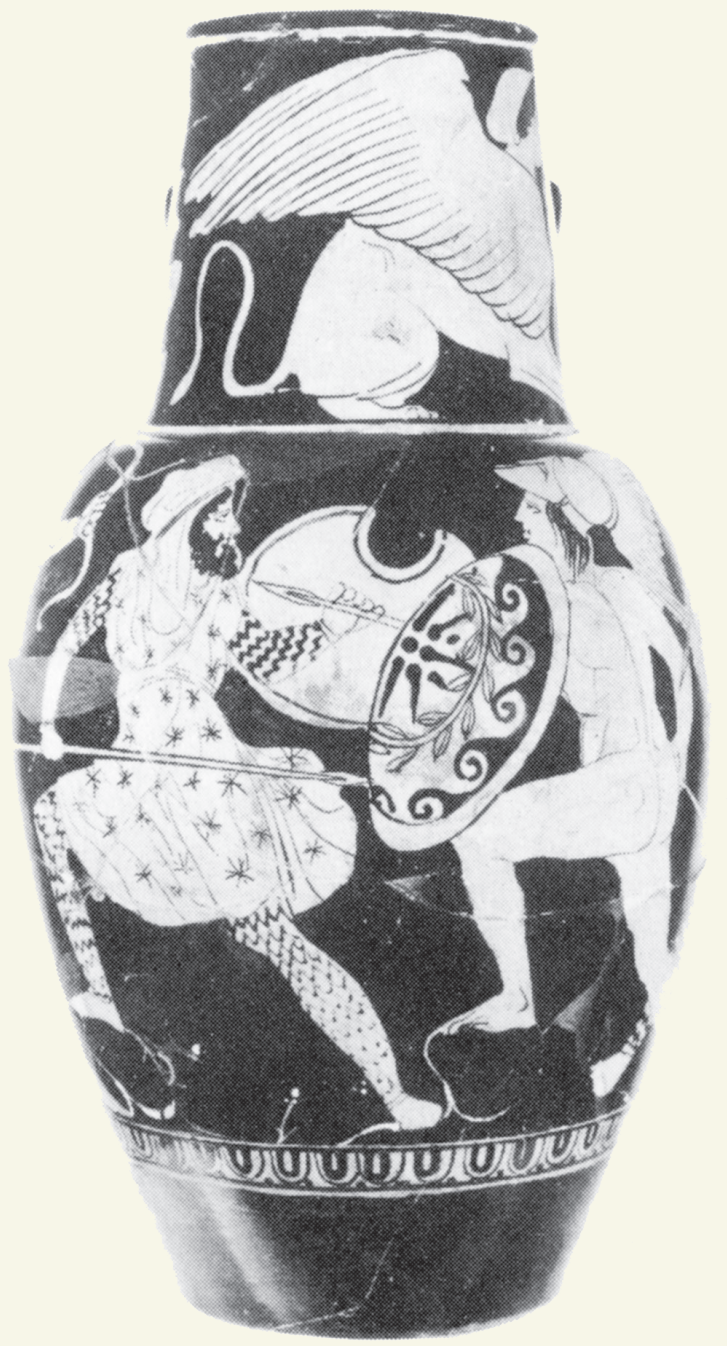

Vaso ateniense que representa um takabara persa (à esquerda) a combater contra um hoplita grego. A cena inspira-se, talvez, na guerra de 390 a. C., entre a Pérsia e Esparta. Museu Nacional do Louvre, Paris. 
mento local. Já referimos que a Paz de Cálias (c. 449 a. C.) responsabilizou os sátrapas ocidentais pela defesa das suas províncias; estes começaram a recolher tributos que antes eram pagos ao Grande Rei. Também se recrutavam, entre as tribos guerreiras do Irão oriental (na Bactriana e na Hircânia, junto ao Mar Cáspio), "mercenários do Rei”, que traziam por vezes algumas inovações. Em meados do séc. v a. C., foi introduzido, por influência dos Sacas, o escudo de cavalaria, uma versão pequena e alongada do spara, também de vime e de couro para ser mais leve e para interferir menos com o ato de montar. Um documento de 421 a. C., citado por Nick Secunda, dá notícia do equipamento que um judeu estava obrigado a fornecer a um cavaleiro persa: cavalo com arnês e xairel de ferro, elmo, couraça de couro, escudo, 120 flechas e duas lanças...

Com a Paz de Cálias e o fim das guerras expansionistas, a atividade militar dos Persas virou-se para dentro, assumindo então, entre 450 e 400 a. C., a forma de lutas intestinas. Durante este período, a cavalaria pesada evoluiu para táticas de choque que incluíam formações em coluna, para acrescentar ímpeto à carga. Também se generalizou o recurso a mercenários gregos, até porque a política persa - para prevenir as revoltas - estimulara a maioria das nações a deixar de treinar os seus jovens, pelo que uma boa parte dos mercenários tinha de ser contratada nas 'nações livres' do Ocidente. A célebre revolta do príncipe Ciro "o Jovem" contra Artaxerxes II, em 401 a. C., por exemplo, envolveu 10000 mercenários hoplitas oriundos da Arcádia e da Acaia. Também havia algumas fontes internas de recrutamento de mercenários, mas neste caso tratava-se de takabara, ou seja, de tropas nativas equipadas com escudo de couro (taka), que eram utilizadas em tarefas diversificadas (incluindo patrulhamentos e guarnições), mas que também podiam servir (em reforço dos sparabara) para o corpo a corpo na linha da frente.

O extremo final do séc. V a. C. foi também marcado, na Pérsia, pela rebelião do Egito (405 a. C.), algo que condicionaria a política externa do Grande Rei nas décadas seguintes. No imediato, interessa recordar a campanha de Artaxerxes II na Grécia, contra Esparta, que se seguiu ao apoio concedido pelos Espartanos ao jovem Ciro. Já sabemos que, em 396 a. C., 
Farnabazo surpreendeu o rei Agesilau, em marcha para Dascília; vale a pena sublinhar agora a carga devastadora executada nesta ocasião pela cavalaria persa, formada em coluna e munida de selas persas! Xenofonte foi testemunha ocular do evento e apressou-se a recomendar o procedimento. Farnabazo viria também a utilizar combinações interessantes de couraceiros com carros de guerra, o que lançava o terror entre os adversários. Curiosamente, esta guerra entre a Pérsia (com as suas aliadas gregas) e Esparta, que desaguaria na Paz de Antálcidas, pôs a nu o fraco equipamento que a infantaria persa ainda apresentava. Na Ciropedia, Xenofonte parece recomendar a combinação do tradicional poder de tiro dos arqueiros mesopotâmicos com a potência da infantaria pesada, algo que Filipe II e Alexandre não desdenhariam...

Entretanto, a paz de 387 a. C. libertara novos mercenários gregos para servir com o rei persa. Chipre, que se rebelara, foi então reconquistada e, em 379 a. C., Farnabazo começou a preparar uma expedição ao Egito. Para o efeito, desejava poder contar com muitos mercenários gregos e pediu a Atenas a cedência do general Ifícrates, que servira sob o seu comando na batalha naval de Gnido. Porém, a guerra estalara de novo na Grécia (entre Tebas e Esparta) e, assim, os Persas 'apenas' conseguiram reunir 20000 mercenários gregos, dos quais somente 8000 seriam hoplitas e poucos teriam o treino adequado. Então, Ifícrates decidiu criar um peltasta que fosse capaz de lutar na linha da frente e de enfrentar os hoplitas. Ou seja, transformou os 12000 mercenários gregos não hoplitas em takabara, mas reforçou o respetivo equipamento, igualando as dimensões do escudo hoplita e, sobretudo, aumentando as lanças desde os 2 a 2,5 $\mathrm{m}$ habituais nos hoplitas e nos takabara até obter um pique de 3,5 metros. Esta alteração permite compreender o sucesso do exército macedónico: alguns autores (como G. P. Best) admitem estar aqui a inspiração para as sarissas (os piques longos) que Filipe II introduzirá na sua reforma militar; no entanto, a sarissa, tal como a lança hoplita, nunca chegou a ser usada como arma de arremesso, e o termo "peltasta" tendeu a significar, cada vez mais, 'infantaria ligeira' equipada com pelte (mais do que um tipo muito particular de tropa ligeira).

A campanha egípcia correu mal e Farnabazo e Ifícrates foram substituídos por Dátames e Timóteo. Entretanto, na Grécia, dera-se a batalha de Leuctras, com o declínio de Esparta e o surgimento das Ligas da Arcádia e 
da Acaia. O paradigma da cidade-estado com o seu próprio exército tendia a evoluir para unidades federais mais amplas, que contavam com tropas permanentes compostas por guerreiros selecionados. Deste modo, cada vez mais escasseavam os mercenários gregos para servir a Pérsia. Perante este cenário, Dátames e Timóteo recorreram aos 120000 nativos que tinham à sua disposição e decidiram equipá-los e treiná-los como hoplitas. Assim nasceram os kardaka (ou "cárdaces"). Ao mesmo tempo, na cavalaria, evoluiu-se do couraçado persa para o catafractário pesadamente equipado, tendo sido introduzidas as proteções de braços (cf. Xenofonte). Algumas intrigas e conspirações levariam, porém, à demissão de Dátames e lançaram a Pérsia em dez anos de rebelião (c. 368-358 a. C.), com devastação das satrapias ocidentais e perda de qualidade da cavalaria. Mas, em 358 a. C., subiu ao trono Artaxerxes III, que reinou de forma muito competente durante vinte anos e que concretizou mudanças e conquistas relevantes.

Em primeiro lugar, Artaxerxes III desmobilizou os exércitos das satrapias, que já não eram capazes de manter a paz nas fronteiras ocidentais. Depois, tratou de aproveitar a disponibilidade dos Estados gregos para, devido a graves dificuldades financeiras, alugarem o seu exército em tempo de paz: contratou o forte exército de Tebas e lançou-se na reconquista do Egito, que completou em 343 a. C., contando com um exército à base de contingentes militares gregos completados com unidades de cárdaces. Por fim, dedicou-se à reforma das instituições persas, de modo a assegurar a paz e a ordem regulares. Uma das suas medidas consistiu em criar colónias para veteranos de guerra, distribuídas por lugares estratégicos do Império.

A morte de Artaxerxes III, em 338 a. C., colocou o poder nas mãos do eunuco Bagoas, que dominou o jovem rei Artaxerxes IV. As satrapias da Babilónia e do Egito revoltaram-se, enquanto Filipe II da Macedónia começava a preparar um ataque sobre a Ásia Menor. A nobreza persa dividiu-se e um sátrapa, que era primo de Artaxerxes IV, começou a destacar-se. Segundo Diodoro da Sicília, Artaxerxes IV pretendeu afastar Bagoas, mas foi morto no verão de 336 a. C. Então, o primo do jovem rei assassinado marchou sobre Persépolis e conquistou o trono. Chamava-se Dario III Codomano e a sua primeira medida foi mandar executar Bagoas. Pouco depois, um general grego ao serviço da Pérsia conseguia repelir os primeiros comandos 
macedónicos na Ásia Menor. A Pérsia parecia pôr a sua casa em ordem, tanto mais que, em outubro de 336 a. C., ocorria o desaparecimento de Filipe II da Macedónia.

Era esta a altura certa para Alexandre Magno entrar em ação. Tinha pela frente um adversário poderoso, mas com evidentes pontos fracos a nível militar: uma infantaria pesada ainda por consolidar (a contratação de mercenários gregos não ajudava, apesar das experiências de Ifícrates e de Dátames); um exército multiétnico e com armamento muito heterogéneo, consoante os contingentes das satrapias; e uma carência clara em matéria de combinação das várias armas, o que lhe retirava harmonia tática. É certo que, desde Ciro "o Grande", a cavalaria persa crescera imenso e começara-se a tirar partido do seu potencial, dispondo-a sobretudo nas alas, em posição de atacar os flancos do adversário; em contrapartida, os carros de guerra haviam perdido algum espaço, sendo utilizados de forma mais pontual. Contudo, um novo padrão militar, coerente e eficaz, estava ainda por implantar nesse vasto Império que se estendia do Mar Egeu até à cordilheira do Hindu-Kush - a espinha dorsal do Afeganistão montanhoso, nos contrafortes dos Himalaias.

\section{A síntese macedónica - Filipe II e Alexandre Magno}

Filipe, que nascera em 382 a. C., era filho do rei Amintas III e irmão mais novo do monarca Perdicas III. Quando este morreu na guerra contra o rei dos Ilírios, Bardílis, Filipe começou a governar a Macedónia, aproveitando a menoridade do seu sobrinho, Amintas IV. O pequeno Estado macedónico estava então à beira do colapso e Filipe, que fora tomado como refém (talvez entre 368 e 365 a. C.) pelo general tebano Pelópidas, tinha planos para o salvar. Começou a preparar o seu exército e, na primavera de 358 a. C., obteve uma vitória sobre Bardílis, conseguindo libertar algumas províncias e integrar alguns povos tribais no seu Estado. Filipe ambicionava tornar a Macedónia a maior potência dos Balcãs e tratou de fazer conquistas em regiões que constituíssem uma boa fonte de ouro, de prata e de mercenários. 
Até 354 a. C., obteve diversas vitórias sobre os Ilírios (a ocidente) e sobre os Peónios (a norte), apoderou-se das colónias costeiras gregas e alargou a fronteira nascente da Macedónia. Atenas e Tebas estavam então ocupadas noutras guerras e Filipe aproveitou o contexto. Negociou uma aliança com a Liga Calcídica (cidades a leste da Macedónia que tinham rompido com Atenas), outra na Tessália e ainda uma outra no Epiro (atual Albânia). Desta última aliança, resultou o seu casamento com Olimpíade, que viria a ser a mãe de Alexandre.

Com a situação mais aliviada, Filipe começou a olhar para a Grécia. Envolveu-se na Guerra Sagrada decretada por uma maioria de membros da Liga Anfictiónica contra uma minoria composta por Atenas, Esparta, Acaia e, mais tarde, Feras; a Liga tinha um Conselho que ditava regras de conduta em matéria religiosa e que administrava o Templo de Apolo, em Delfos. A seguir, Filipe expulsou os ditadores de Feras e foi eleito Presidente da Liga Tessálica. Como observou J. Keegan, tornava-se evidente a deslocação do poder na Grécia, das cidades do sul e do centro (minadas por crises e por guerras) para os Estados do norte (Tessália e Macedónia).

Em 349 a. C., a Liga Calcídica, ao aliar-se a Atenas, deu a Filipe um pretexto para invadir a península calcídica e capturar Olinto, que foi arrasada. Mais povos foram então integrados no reino macedónico. Seguiu-se uma vitória sobre os Fócios e a entrada da Macedónia para a Liga Anfictiónica. O objetivo principal de Filipe era promover um 'tratado de paz comum', que incluísse as cidades-estado gregas e a Macedónia. Todavia, Atenas, Esparta e Tebas não pareciam dispostas a aceitar a ideia: tal desencontro acabou por contribuir para a guerra entre Atenas e a Macedónia.

Já ao comando das forças da Liga Anfictiónica (para desespero de Demóstenes, o grande orador e político de Atenas, que bem alertara para a ameaça macedónica), Filipe, a pretexto de castigar o estado 'sacrílego' de Anfissa, conduziu o seu exército através da Fócida, até à fronteira da Beócia, de modo a ameaçar Tebas e Atenas. As duas cidades uniram-se e isso conduziu a uma batalha decisiva: Queroneia, em agosto de 338 a. C., onde tropas de Atenas, da Beócia (incluindo Tebas), de Mégara, de Corinto e da Acaia foram vencidas pelos Macedónios e os seus aliados. Filipe simulou uma retirada da sua falange (na ala direita) e induziu a ala esquerda 
ateniense a persegui-la; abriu-se então uma brecha na formação adversária, que Alexandre, no comando da cavalaria macedónica (na ala esquerda), aproveitou para uma carga devastadora. Metade dos Atenienses pereceu ou foi aprisionada.

Depois de Queroneia, autêntico tirocínio para o jovem Alexandre, Filipe avançou para o Peloponeso, onde apenas Esparta lhe permaneceu hostil. O rei da Macedónia tinha finalmente condições para lançar o seu projeto de uma Comunidade Grega ou Liga Helénica. A proposta foi apresentada no outono de 338 a. C. e seria aceite na primavera seguinte. Eis a Liga de Corinto, com um Conselho Comum (com poderes financeiros, disciplinares e judiciais) e com um exército comum (ficando os soldados estabelecidos em Corinto, em Tebas e em Ambrácia). O objetivo era manter a paz entre os membros, que deveriam unir-se contra qualquer agressor, interno ou externo, mas a Liga selou também uma aliança defensiva e ofensiva com o Estado da Macedónia. Em finais de 337 a. C., foi declarada guerra à Pérsia e Filipe foi eleito comandante das forças unidas (ou seja, hegemon desta coligação pan-helénica).

$\mathrm{Na}$ primavera de 336 a. C., três generais macedónicos comandaram a vanguarda das forças da aliança que partiu para a Ásia, visando instalar aí uma 'testa de ponte' para uma guerra de vingança da Grécia contra a Pérsia. Segundo o previsto, as forças principais, sob o comando de Filipe, deveriam avançar no outono, com o objetivo de libertar as cidades gregas da Ásia Menor e de reconquistar territórios. Devemos admirar o génio político, diplomático e militar de Filipe, ao conseguir pôr de pé este projeto, que suscitava reservas em algumas cidades gregas (que receavam uma derrota, ou que entendiam - com bons motivos - esta aliança como uma forma de a Macedónia dominar a Grécia).

Logo em 336 a. C., as forças aliadas conseguiram obter vitórias importantes na Ásia, sob o comando de Parménio, de Átalo e de Amintas. Com o apoio de uma frota, libertaram cidades gregas da costa ocidental, tendo chegado até Éfeso. A Pérsia demorou a reagir e fê-lo através do general Mémnon de Rodes, um comandante de mercenários gregos. Entretanto, o desembarque da coluna principal da Liga, previsto para o outono, não chegaria a efetuar-se: em outubro desse ano, durante um festival em Egas, 
Filipe II foi assassinado por um dos seus guarda-costas, um ato que muitos relacionam com os Persas, outros com uma vingança pessoal de Pausânias e outros ainda com uma dissensão surgida entre Olimpíade e Filipe, em resultado de um novo casamento do rei, que punha em risco a posição de Alexandre.

Explica Demóstenes, nas Filípicas [3.47-50], que o rei macedónico "não obtém a vitória graças à sua falange de hoplitas, mas devido às tropas ligeiramente armadas, cavalaria, arqueiros, mercenários e tropas equipadas de modo similar". Ou seja, o exército de Filipe II era uma máquina distinta da tradição hoplita.

Não se sabe bem quando começou a reforma do exército macedónico, mas presume-se que tenha sido pouco antes da ascensão de Filipe, talvez no reinado de Alexandre II (370-368 a. C.). Na Macedónia, havia uma forte tradição de cavalaria, com a nobreza local a fornecer bons cavaleiros. A base do exército macedónico era, pois, constituída pelo Esquadrão Real dos Companheiros (ile basilike ou agema), uma unidade de elite que Filipe ajudou a evoluir de uma espécie de cavalaria feudal para uma arma formidável. Lutavam em embolos, isto é, em cunha triangular com forma de letra delta (maiúscula), em que um dos vértices era apontado ao adversário. Tratava-se de um dispositivo bom para rodar ou para retirar e ótimo para penetrar a cavalaria adversária, ou mesmo - uma vez que os cavaleiros utilizavam o pique longo ou sarissa - para romper a infantaria munida da lança típica dos hoplitas. O pique era geralmente transportado debaixo do braço (apertado entre o cotovelo e o tronco) e a sua conteira dispunha de uma cabeça de ferro, o que permitia golpear peões ou cavaleiros derrubados. Como não havia ainda o estribo, os golpes principais, desferidos de baixo para cima, não dispunham de força suficiente para matar os adversários, pelo que se tentava visar a sua cara (ou a cabeça do cavalo) e provocar a queda do cavaleiro.

Durante a sua campanha asiática, Alexandre aumentou muito a força dos Companheiros. Logo que atravessou o Helesponto (estreito de Dardanelos, separando a Europa da Ásia), acrescentou sete esquadrões ao núcleo régio original, pelo que, em Gaugamela, encontraremos oito ilai sob o seu 
comando, num total de 1800 a 2000 Companheiros. Mais tarde, o número tenderia a crescer conduzindo, primeiro (em 331 a. C.), a uma subdivisão dentro de cada esquadrão (dois lochoi em cada ile) e, no ano seguinte, ao aparecimento das hiparquias (oito esquadrões divididos em dois grupos de quatro, num total, talvez, de c. 4000 cavaleiros).

Para além dos Companheiros, Filipe e Alexandre recorreram à cavalaria da Tessália, considerada a melhor região da Grécia para a criação de cavalos. O seu valor é mais controverso, pois estava treinada nas táticas habituais de cavalaria anteriores a Alexandre, ou seja, a lutar contra formações pouco profundas, ou contra cavalaria ligeira. A cavalaria tessálica formava em rhombos (em forma de diamante, uma invenção do arconte de Feras, Jasão) e, ao contrário dos Companheiros, Alexandre utilizou-a sobretudo na ala esquerda do seu exército, disposta também em esquadrões.

Em matéria de cavalaria ligeira, Filipe e Alexandre apostaram sobretudo nos esquadrões dos Prodromoi, em número de quatro e cada qual com 150 cavaleiros. Munidos da sarissa, estes esquadrões eram geralmente compostos por aliados trácios (odrísios e outros) ou peónios. Eram muito úteis na defesa dos flancos da cavalaria principal (os Companheiros, à direita, e os Tessálios, à esquerda). Segundo A. Devine, estes cavaleiros (sobretudo os Trácios) começaram a utilizar a formação em delta antes mesmo dos Macedónios.

Mas Filipe e Alexandre não desprezavam as tropas apeadas. Na Macedónia, já existia uma força de infantaria desde pelo menos o rei Arquelau (413-399 a. C.), como nos conta Tucídides. No entanto, foi Filipe quem a transformou numa unidade de combate. Para isso contribuiu a introdução (logo no início do seu reinado) da já citada sarissa. Era uma lança muito comprida, podendo oscilar entre os 4 e os 7 metros. Ao tempo de Alexandre, sabemos que teria entre $4,5 \mathrm{~m}$ e $5,5 \mathrm{~m}$ e que pesaria à volta de $6 \mathrm{~kg}$. Fabricada em madeira de cornizo, era manejada pelos peões com ambas as mãos. Encabada na haste, continha uma cabeça de ferro com cerca de meio metro e, na conteira, um espigão de ponta cónica que permitia à infantaria espetar a arma no solo e apontá-la de forma a empalar os peitos dos cavalos inimigos. 
Se os Companheiros a cavalo eram a quinta-essência do exército macedónico, a falange de infantaria munida da sarissa constituía a sua espinha dorsal. Filipe criou mesmo os "Companheiros a Pé" (os pezhetairoi), que sabemos, através de Demóstenes, já existirem em 349 a. C. (apesar de o termo ser anterior a Filipe, podendo então servir para designar apenas a guarda real). Os falangistas macedónicos estavam equipados com um pequeno escudo de bronze (suspenso ao pescoço, já que as mãos estavam mais ocupadas com a sarissa), com um elmo macedónico (mais caro do que o coríntio, mas mais leve e mais aberto), com um simples corselete de couro (a muralha de sarissas dispensava o uso de peitorais mais robustos) e, no caso das primeiras fileiras, com grevas para proteção das pernas. Como segunda arma ofensiva, dispunham de uma faca ou de um punhal.

A falange macedónica, vista de fora, era impressionante. O habitual era cada um dos batalhões formar com 16 fileiras de profundidade e outro tanto de frente. Geralmente, o falangista tinha um terço da sarissa das suas mãos para trás e projetava o resto da arma para diante. Assim, numa sarissa com seis metros de comprimento, isto quer dizer que quatro metros da arma, no caso dos homens da linha da frente, eram projetados na direção do inimigo. Os falangistas da segunda fila, posicionados um metro atrás dos camaradas da linha da frente, projetavam a arma três metros para além da linha da frente, mas elevavam-na ligeiramente. As sarissas dos homens da terceira fila sobressaíam dois metros em relação à linha dianteira e eram elevadas um pouco mais. Os soldados da quarta fila já só conseguiam projetar a sua arma um metro para além da linha da frente, mas a sarissa ficava bastante elevada. E, por fim, os da quinta fila levantavam os seus piques longos quase à altura da cabeça dos companheiros da linha da frente. Nas filas mais recuadas, as sarissas eram transportadas na vertical, dando forma definitiva a uma 'sebe pontiaguda', que se revelava impenetrável, mesmo para elefantes de guerra como os que Alexandre defrontaria no rio Hidaspes.

Do ponto de vista tático, a função da falange macedónica era muito distinta da hoplita (mais pesadamente equipada). Ela servia sobretudo para fixar e abalar a infantaria adversária, graças à vantagem conseguida no momento do primeiro choque, devido ao comprimento das sarissas (duas 
vezes mais longas do que as lanças dos hoplitas). Os adversários tinham muita dificuldade em aproximar-se sem grandes riscos e em chegar ao contacto com a falange macedónica, cujo movimento se assemelhava mais a um avanço do que propriamente a uma carga. A 'sebe eriçada movediça' facilmente acabava por abrir brechas na formação opositora, com isso criando condições propícias a uma carga fulminante da cavalaria. Ora aqui está a principal diferença em relação aos hoplitas: com Filipe, a falange já não desempenha o papel principal, embora seja essencial para abrir caminho ao golpe decisivo da cavalaria! A falange macedónica era, pois, especialmente boa em articulação com outras 'armas', em particular com a cavalaria que atuava nos flancos ou na retaguarda, mas também com infantaria ligeira composta por atiradores de diverso tipo.

Tratou-se de um grande passo em frente em matéria de arte militar. O falangista macedónico era um produto híbrido muito bem conseguido: sendo comparável ao peltasta trácio quanto ao peso mais aligeirado do seu equipamento defensivo, ao mesmo tempo diferenciava-se dele porque o peltasta manejava com uma só mão uma lança, de arremesso ou de choque. Ora, em batalha, o falangista macedónico atuava como se fosse um verdadeiro hoplita, ou seja, em falange cerrada, e até com redobrada confiança, pois dispunha de uma lança muito mais comprida e os seus flancos estavam bem protegidos pela cavalaria. Em síntese, superava em muito os seus antecessores, tanto os hoplitas como os peltastas-takabara de Ifícrates ou os cárdaces de Dátames.

Os pezhetairoi eram repartidos por vários batalhões (taxeis), suficientemente largos para poderem atuar com autonomia tática ou em conjunto. Cada taxis desdobrava-se em unidades mais pequenas, tal como ensinava a boa tradição espartana. Era o caso da dekad, do lochos (possivelmente uma invenção de Filipe) e da syntagma, em volume crescente e geralmente em múltiplos de 16 (a própria dekad deve ter evoluído de 10 para 16 homens). Na campanha asiática, Alexandre terá contado com 9000 falangistas organizados em seis taxeis de 1500 homens cada, com treino suficiente para conseguirem formar em linha reta, em traçado oblíquo (como os Tebanos em Leuctras), em crescente, em seta ou em quadrado. 


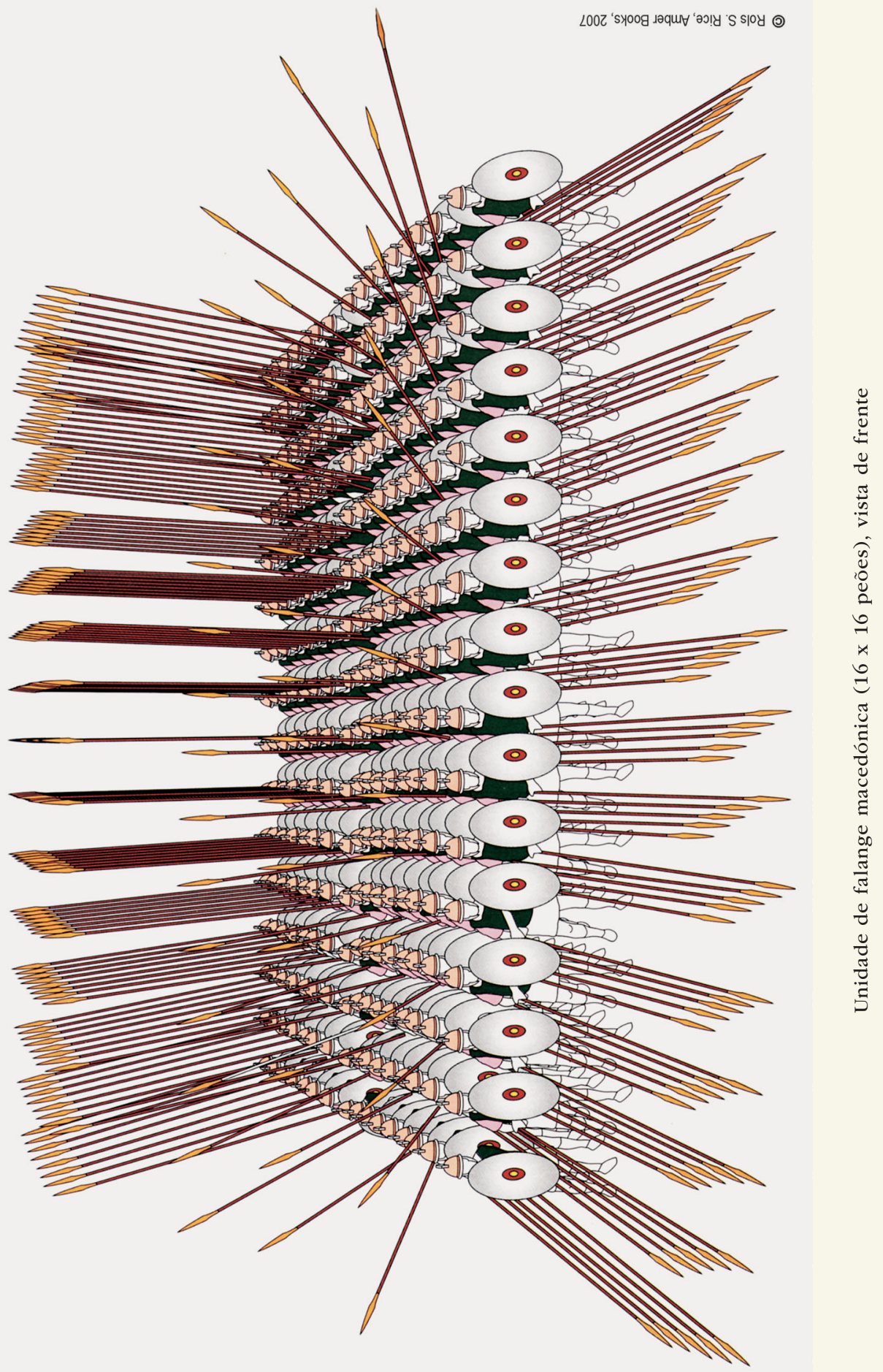


Os Macedónios dispunham ainda de um outro corpo de infantaria de elite, provavelmente criado a partir de uma seleção no seio dos pezhetairoi. Trata-se dos hipaspistai, sobre os quais dispomos de escassas informações mas que devem ter sido a primeira força profissional que existiu na Macedónia. Asseguravam um serviço ininterrupto ao rei, a quem dedicavam uma lealdade total, até porque eram escolhidos por ele e podiam integrar a sua guarda. O equipamento devia ser semelhante ao dos pezhetairoi. Seriam em número de 3000, divididos em três quiliarquias de um milhar de elementos (cada qual repartida em unidades mais pequenas). Sabemos que, em 327 a. C., decoravam os seus escudos com pequenas placas de prata. Os pezhetairoi e os hipaspistai ocupavam as posições centrais na primeira fila, com os Companheiros à sua direita e a cavalaria tessálica à esquerda. Treinavam com os cavaleiros as diversas formações de batalha que era possível armar em combate, desde o lambda ou delta (maiúsculo) utilizado por Epaminondas em Leuctras (ou, possivelmente, por Alexandre em Pélio, em 335 a. C., contra os Ilírios) até cunhas mistas de cavalaria e infantaria, como a que Epaminondas terá talvez utilizado em Mantineia.

Quanto a tropas ligeiras, é certo que elas tiveram mais importância entre os Romanos e os Cartagineses. Ainda assim, tal como o trecho de Demóstenes sugere, Filipe recorreu à utilização de arqueiros cretenses, de dardeiros trácios e de fundibulários ródios, entre os quais muitos mercenários. Os atiradores protegiam a cavalaria principal antes de esta atacar, ajudavam a desorganizar as formações inimigas e neutralizavam os condutores dos carros ou dos elefantes. Correndo atrás ou ao lado dos cavaleiros, podiam também atuar como hamippoi, acabando com a vida dos cavaleiros adversários que haviam sido derrubados. Pelo seu lado, a infantaria grega auxiliar podia ser útil como uma espécie de segunda linha, posicionada atrás da falange com a função de contrariar qualquer envolvimento adversário ou um ataque à retaguarda.

Em síntese, o exército concebido por Filipe e aperfeiçoado por Alexandre era uma máquina militar completa (e nem considerámos aqui o seu mostruário de armas de cerco). Profissional, fazia a guerra de verão e de inverno, era capaz de efetuar longas marchas (como sucedeu antes de 
Queroneia), sabia guardar sigilo acerca dos seus planos reais (e induzir o adversário em erro sobre as suas intenções), preparava-se bem e gostava de avançar depressa para desferir ataques de surpresa. Não era um exército perfeito, mas, como observou F. Adcock, a junção do profissionalismo com o espírito nacional macedónico e com a grande liderança de Filipe II tornavam-no uma máquina difícil de travar. Em Queroneia (338 a. C.), Filipe e Alexandre, cada qual em seu flanco e com o seu tipo de tropa, mostraram bem do que eram capazes, ao criar para si próprios uma vantagem tática e ao saber explorá-la até ao limite, atribuindo a um determinado corpo do exército (a cavalaria dos Companheiros) a missão de alcançar a vitória.

Filipe não viveu o suficiente para assistir ao crescimento desta máquina militar, mas Alexandre honrou a herança de seu pai através de aperfeiçoamentos importantes, como o dispositivo em seta (que facilitava o rompimento da formação adversária pela ampliação da carga desferida) ou a exploração dos espaços entre os batalhões dos falangistas. Segundo Adcock, entre Filipe e Alexandre havia a mesma distância que separa um jogador de damas de um jogador de xadrez...

É certo que os Macedónios tiveram o tempo histórico a seu favor, pois a Pérsia Aqueménida tinha estendido o seu Império para além das suas capacidades e era vulnerável nas regiões periféricas, como notou Keegan. Mas, beneficiando da vantagem política que decorria de não serem uma monarquia limitada por instituições ou por magistrados, souberam aproveitar bem esse tempo favorável. Filipe II e Alexandre Magno conciliaram muito bem a herança militar do Médio Oriente (a da cavalaria de choque) com a tradição grega da infantaria pesada. Conseguiram fazê-lo porque, como bem notou Henrique Modanez, estavam suficientemente próximos dos Gregos para perceber a importância da disciplina na guerra de choque frontal das falanges, mas suficientemente longe deles para combinar isso com tropas montadas de inspiração persa. Ao contrário, os Gregos viviam demasiado focados no ideal cívico associado ao choque frontal, enquanto os Persas foram incapazes de atribuir centralidade à falange devido à ausência de convenções militares de tipo helénico. A receita estava inventada, a cena estava montada, o pano tinha subido, o espetáculo da conquista podia, enfim, começar! 


\section{O início da grande aventura}

Tendo subido ao trono em 336 a. C., com apenas 20 anos, Alexandre beneficiou do apoio de dois dos principais generais de Filipe (Antípatro e Parménio) para conseguir controlar a máquina que herdara do pai e dominar a concorrência desejosa de tirar partido da sua juventude. A dificuldade maior, nesta altura, consistia em expandir a sua autoridade para lá da Macedónia, uma vez que a Liga de Corinto não estava ainda consolidada e que a morte inesperada de Filipe suscitara algum tumulto no seio das cidades gregas.

Alexandre começou por assegurar o controlo da Tessália, tendo de seguida avançado para a Grécia. Durante esta marcha, conteve a revolta dos Tribalos (um povo da Ilíria) e dominou a sublevação dos Ilírios na costa leste do Mar Adriático (vitória na batalha de Pélio, em 335 a. C.). Por essa altura, correu o boato da morte de Alexandre, o que estimulou a revolta de alguns tebanos exilados. Com receio de uma aliança entre Tebas, Atenas, Esparta e a região da Etólia, Alexandre decidiu pôr cerco à cidade de Tebas. Como exemplo para as restantes poleis, Tebas foi destruída e 8000 dos seus cidadãos foram vendidos como escravos!

Ao longo do inverno de 335-334 a. C., Alexandre e Parménio prepararam a invasão da Pérsia. Investido do estatuto de hegemon (contando para o efeito com o apoio de todas as cidades gregas, com exceção de Esparta), Alexandre tinha agora condições políticas e militares para concretizar o sonho de Filipe, tanto mais que Dario III como que adormecera sobre os louros de uma vitória de Mémnon de Rodes e ninguém parecia controlar a costa, nem havia sinais de mobilização da frota persa com a finalidade de travar qualquer investida grega.

Assim, na primavera de 334 a. C., Alexandre deu o tiro de partida para a grande marcha. Contaria na altura com c. 30000 soldados de pé (entre Macedónios, Gregos, Trácios e outros), para além de uns 5000 cavaleiros (os Companheiros, a cavalaria da Tessália e ainda um contingente de cavaleiros aliados gregos). Por precaução, Alexandre deixara na Europa uma força de 9000 infantes e 600 cavaleiros, sob o comando de Antípatro. A expedição incluía botânicos, geógrafos, especialistas em recursos minerais e muitos outros não combatentes. 


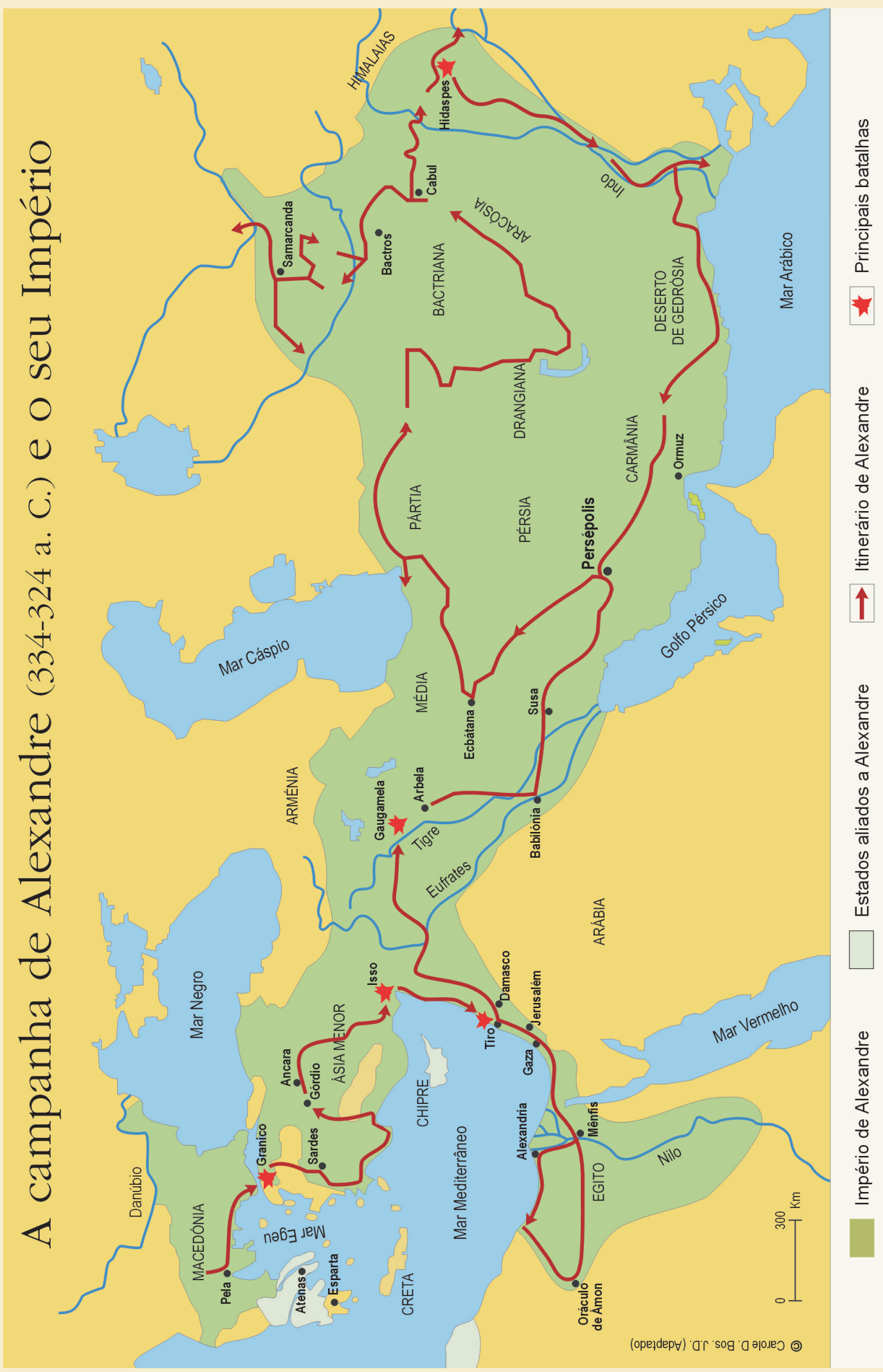


Pouco depois de atravessar o Helesponto e de assentar os dois pés na Ásia, Alexandre teve de enfrentar um exército persa que o aguardava nas margens do rio Granico. Tratava-se de uma força que reunia contingentes de três sátrapas e que contava também com uma forte unidade de mercenários gregos, sob o comando de Mémnon de Rodes. Ao todo, seriam perto de 15000 homens, dois terços dos quais a cavalo.

Alexandre, que partira para a Ásia com preocupações financeiras e que precisava de sucessos imediatos, decidiu arriscar e teve aqui o seu primeiro teste: separou as suas forças, fez com que um dos contingentes atravessasse o curso de água um pouco mais adiante e atacasse de surpresa o flanco esquerdo persa, desbaratando a cavalaria, e depois caiu ele próprio (com os Companheiros e grande parte da falange) sobre a linha da frente adversária, arriscando um assalto frontal. Entregue a si própria e em clara desvantagem face ao comprimento das sarissas macedónicas, a infantaria mercenária grega ao serviço da Pérsia foi chacinada. O projeto persa de liquidar a expedição de Alexandre logo à nascença, eliminando o seu líder (que aliás escapou por pouco de ser abatido, valendo-lhe o socorro de um dos Companheiros: Clito "o Negro"), tinha fracassado. A vitória macedónica foi comemorada com o envio de armaduras persas para Atenas, sinalizando o início prometedor da expedição.

A marcha prosseguiu para sul, perto da linha de costa da Ásia Menor (pela atual Turquia). Passaram por Sardes e aproximaram-se ainda mais do litoral, avançando pela Iónia e libertando as cidades gregas ainda submetidas ao jugo persa, não sem encontrar alguma resistência em Mileto e em Halicarnasso. A seguir, o exército rumou para norte, subjugando a parte central da Ásia Menor, e passou por Górdio, onde ocorreu o episódio do "nó górdio", com Alexandre a desfazer de um só golpe, com a espada, o dito nó, uma façanha de grande significado profético...

Estava-se no final do inverno de 334-333 a. C. e o exército macedónico avançou para Ancara e, depois, desceu na direção da Cilícia (atual Turquia, muito perto da fronteira com a Síria). Por esta altura, já Parménio fora enviado à frente, tentando vislumbrar alguma reação de Dario. Seguiu-se a marcha para o planalto de Isso, onde o Grande Rei (debilitado pela morte de Mémnon no primeiro semestre de 333 a. C.) os aguardava para uma batalha frontal. Dario tinha o seu flanco esquerdo resguardado pelo Mediterrâneo, 
o flanco direito protegido pelas montanhas (a Cilícia estava envolta de três lados pelas cadeias do Tauro e do Amano) e parecia disposto a apostar na capacidade dos seus mercenários gregos e na infantaria dos cárdaces.

Alexandre esperou que Dario tomasse a iniciativa, o que só veio a acontecer em outubro de 333, mas o rei macedónico recusou a batalha na planície da Síria, perto de Sóquios, pois o terreno favorecia a superioridade numérica persa. Alexandre manteve-se na defensiva, jogando com o inverno, e deslocou-se para Miriandro (a sul do desfiladeiro de Beilan), talvez com o fito de atacar os Persas pelo flanco caso eles cruzassem aquela montanha. Porém, Dario conhecia duas travessias alternativas e apanhou Alexandre de surpresa ao marchar debaixo de mau tempo e atravessar o Amano mais a norte, descendo de seguida para a planície costeira e aparecendo na retaguarda dos Macedónios! Aqui, funcionou o sangue-frio de Alexandre, que reagiu depressa e marchou para norte de maneira a medir forças com Dario. As fontes não nos esclarecem muito sobre a batalha de Isso (finais de 333 a. C.), mas é certo que os dois exércitos estavam separados pelo rio Pínaro e que o terreno era estreito (uma faixa de c. $3 \mathrm{~km}$, entre a montanha e o mar) para tanta gente. O choque entre a falange macedónica e a infantaria mercenária grega ao serviço de Dario foi violento, mas a vitória acabou por sorrir a Alexandre, graças sobretudo à ordem oblíqua do seu movimento atacante a partir do flanco direito, o qual, confirmando o princípio tebano da 'coluna alongada' (batalha de Leuctras), rompeu a formação persa e envolveu os flancos interiores do dispositivo de Dario. A capacidade de improviso de Alexandre, a disciplina da sua infantaria e as dificuldades que os Persas (embora em superioridade numérica) ainda sentiam para otimizar a cooperação entre a sua cavalaria e a infantaria pesada terão estado na base do sucesso macedónico.

Dario teve de fugir e Alexandre pôde então desfrutar de um primeiro contacto com a luxúria persa. Conta Plutarco [Vidas Paralelas, Alexandre, 20.13] que, depois de tomar o acampamento persa (onde capturou o arco e o carro de guerra do Grande Rei), Alexandre entrou na ampla tenda de Dario, inundada de aromas perfumados, e se maravilhou perante as bacias, os vasos, a banheira, tudo em ouro ricamente trabalhado; lavou o suor do combate nas louças do seu adversário, gozou as delícias do seu leito e da sua mesa e, finalmente, exclamou: "Então parece que isto é que é ser rei!". 
Ainda em Isso, Alexandre teve o cuidado de dispensar à família de Dario III um tratamento requintado, que foi ao ponto de casar ele próprio com uma das filhas do rei persa, chamada Estatira (apesar de há muito Alexandre ter um companheiro: Heféstion, seu amigo de infância e um dos seus principais comandantes). A seguir, prosseguiu na sua aventura de conquista do grande império. Marchou para sul, entrando na Fenícia (a principal base da frota persa), onde quase todas as cidades se renderam. Porém, Tiro resistiu, tentando permanecer neutral (ao que parece com o encorajamento de Cartago), e Alexandre optou por cercá-la. A cidade estava situada numa ilha fortificada e protegida por torres que atingiam os $46 \mathrm{~m}$ de altura e por uma imensa armada que incluía navios incendiários. Alexandre levou mais de meio ano para capturar Tiro, recorrendo a grandes torres de cerco, a aríetes, a engenhos de torção e a pontões de assalto. A cidade também foi isolada e bloqueada; muitos navios fenícios e cipriotas auxiliaram nesta tarefa, de tal forma que Alexandre, contando já com c. 200 embarcações, conseguiu derrotar a frota de Tiro. Em inícios de agosto de 332 a. C., deu-se o assalto geral à muralha, que apresentava brechas provocadas pelos engenhos instalados a bordo dos navios. A praça foi conquistada e os 2000 cidadãos sobreviventes foram crucificados.

A captura de Tiro foi de extrema importância, pois resolveu em grande parte o problema logístico da expedição macedónica, garantindo a Alexandre o controlo da costa levantina e permitindo-lhe avançar em segurança para o Egito. De tal maneira que uma carta enviada por Dario III ao rei macedónico, propondo a paz em termos razoáveis (que Parménio desejava aceitar), suscitou de Alexandre uma resposta agressiva, que Arriano [Anabasis, 2-14] reproduz e que parece indiciar que os planos do herdeiro de Filipe se tinham tornado mais ambiciosos: "O meu pai foi morto por assassinos que (...) vós mesmos haveis contratado para cometer um tal crime (...); agora eu derrotei-vos e ao exército que vós conduzíeis. Com a ajuda de Deus, tornei-me senhor do vosso reino e tornei-me responsável pelos sobreviventes do vosso exército, que fugiram para junto de mim em busca de refúgio. (...) No futuro, que toda a comunicação que queirais fazer-me seja dirigida ao Rei da Ásia. Tudo o que vós possuíeis é agora pertença minha; como tal, se pretendeis alguma coisa, fazei-mo saber nos termos adequados ou tomarei as medidas 
para lidar convosco como com um criminoso. Se, por outro lado, desejais reclamar o vosso trono, então estabelecei a vossa posição e lutai por ela em vez de fugir. Onde quer que vos escondais, sede certos de que vos irei buscar". O desafio era de uma audácia assombrosa, pois, como vimos, a Pérsia tinha-se tornado senhora de todos os anteriores impérios do Médio Oriente e as suas fronteiras eram vastíssimas...

Para Alexandre, a conquista prévia do Egito era essencial a uma expedição bem-sucedida contra a Babilónia. Tanto mais que, após a batalha de Isso, os Persas tinham procurado recuperar a iniciativa e repor as baixas, tendo enviado exércitos para a Anatólia (Ásia Menor) com o objetivo de estabelecer contacto com a frota persa do Mar Egeu, enquanto Alexandre marchava para sul. Neutralizado o Egito, o exército macedónico poderia marchar com alguma tranquilidade sobre as principais cidades adversárias, situadas nas proximidades do Golfo Pérsico. Alexandre ainda precisou de dois meses para cercar e tomar Gaza (graças a rampas de assalto construídas com terra), posto o que entrou no Egito, onde foi recebido como um libertador. Em Mênfis, fez-se coroar Faraó. Depois, já em 331 a. C., projetou Alexandria, que desejava tornar a grande cidade mercantil do Mediterrâneo, em substituição de Tiro. Seguidamente, fez questão de atravessar o deserto (guiado por cobras, segundo Ptolomeu, ou por dois corvos, segundo Aristobulo) para, rivalizando com Perseu e com Hércules, visitar o oráculo de Ámon Zeus (na atual Líbia). Numa evidente ação de propaganda, o sacerdote declarou-o filho de Zeus e prometeu-lhe a conquista do mundo...

\section{A caminho da batalha}

Completada a operação no Egito, Alexandre regressou a Tiro. Estava-se no ano de 331 a. C. e o rei macedónico tinha noção de que Dario se preparava para o travar, caso ele decidisse avançar para a conquista do coração do Império Persa. Tinham passado já muitos meses desde o combate que haviam travado em Isso, e era de presumir que o Grande Rei tivesse aproveitado o tempo para mobilizar um exército capaz de lhe proporcionar uma boa desforra. Entre outras ações, os Persas tinham recrutado tropas na 
Babilónia para compensar os cárdaces mortos em Isso; as lanças de cavalaria tinham sido aumentadas e havia-se completado a formação dos catafractários; os couraceiros persas tinham trocado os dardos pela lança de duas mãos.

Dario III, acompanhado de uma força com mais de 80000 homens (incluindo pelo menos 30000 cavaleiros), apoiada por 200 carros de guerra e por 15 elefantes, avançara quase $500 \mathrm{~km}$ a partir de Babilónia na direção do norte da Mesopotâmia e posicionara-se perto de Arbela, cidade localizada numa das grandes planícies entre o rio Tigre e as montanhas do Curdistão (no atual norte do Iraque). Era uma região de solo arenoso e relativamente plana, propícia às manobras militares da maior hoste da Ásia. Na retaguarda, as zonas montanhosas da Arménia e do norte da Média garantiam a Dario uma proteção confortável, tanto mais que ele próprio fora sátrapa nesta região e dela poderia esperar algum apoio e refúgio em caso de necessidade.

Dario sabia que Alexandre, no seu regresso do Egito, teria de se deslocar para norte, ao longo da costa da Síria, antes de atacar as províncias centrais do Império. Como observou E. Creasy, uma marcha direta para leste, partindo da parte inferior da Palestina e atravessando o deserto arábico, seria impraticável. Pelo contrário, dirigindo-se para oriente a partir da Síria, Alexandre conseguiria alcançar as ricas planícies mesopotâmicas sem grande dificuldade. As capitais persas (Babilónia, Susa, Persépolis) ficar-lhe-iam então a sul e, caso Alexandre descesse para as atacar, Dario teria uma ótima oportunidade para perseguir os Macedónios e para fustigar a respetiva retaguarda, cortando também a linha de comunicações do adversário e dificultando o seu abastecimento. Se, pelo contrário, Alexandre optasse por adiar a sua marcha sobre a Babilónia e buscasse primeiro uma batalha com os Persas, a região dos dois lados do Tigre em que Dario se tinha posicionado era, àquela latitude, bastante vantajosa para uma hoste tão poderosa em cavalaria quanto a do Grande Rei.

Em finais de agosto de 331 a. C., Alexandre, cujo exército ia vivendo do que a terra dava (tirando partido do bom sistema de aprovisionamento do Império Persa), atravessou o rio Eufrates nas imediações de Tápsaco, orientando a sua marcha para nascente. Por essa altura, teve de repelir um pequeno corpo de cavalaria que lhe apareceu pela frente, sob o comando de Mazeu (o sátrapa da Babilónia e um dos melhores generais de Dario). 
O rei macedónico avançou então quase a direito para o rio Tigre, através do noroeste da Mesopotâmia. Por razões logísticas, e desde que o adversário não lhe saísse ao caminho, Alexandre optaria certamente por avançar depois para sul, seguindo a margem esquerda do rio ao longo das faldas de uma região montanhosa, onde os seus homens se defenderiam melhor do calor e onde poderiam encontrar um aprovisionamento mais abundante.

Informado da movimentação do inimigo, Dario decidiu conservar a sua posição junto à aldeia de Gaugamela (ou Gaugamelos), na margem esquerda do Tigre. A posição era excelente e, se o Grande Rei tivesse a ventura de ali alcançar uma vitória, Alexandre, com as montanhas pela frente e os rios Tigre e Eufrates nas suas costas, estaria perdido. Assim, Dario aquartelou algumas das suas forças em Arbela (a sudeste de Gaugamela) e ali mandou guardar a parte mais valiosa do tesouro de que se fazia acompanhar.

Pelo seu lado, Alexandre, ao tomar conhecimento da proximidade de Dario, cruzou o Tigre e, após um breve descanso, tentou obter uma indicação sobre a posição exata do adversário. Conseguido isso, instalou e fortificou o seu acampamento num ponto relativamente elevado, situado a cerca de $6,5 \mathrm{~km}$ de distância dos Persas, ou seja, suficientemente perto para controlar os seus movimentos e suficientemente longe para prevenir qualquer surpresa. Alexandre seguiu então o conselho do seu principal general (Parménio) e tratou de reconhecer o campo de batalha escolhido pelo monarca persa. Tratava-se de uma área bastante plana, com perto de $20 \mathrm{~km}$ quadrados e que Dario mandara desbravar e nivelar ainda mais, rasgando (como observou J. Keegan) três 'avenidas paralelas', de modo a ficar seguro de poder utilizar os carros de guerra em que - na boa tradição oriental - os Persas depositavam tanta esperança.

Esclarecido, Alexandre encorajou as suas tropas e mandou-as jantar e dormir bem. Ao cair das trevas, Parménio terá ainda sugerido um ataque noturno ao acampamento inimigo, hipótese que o rei macedónico rejeitou, alegando não ser fácil controlar um grande exército na escuridão, nem ser essa uma manobra digna de um príncipe como ele. Com esta decisão, Alexandre não só assegurou o repouso dos seus bravos como frustrou os Persas, que aguardavam esse ataque noturno e que, por isso, passaram grande parte da noite em vigília e com as armas a postos... 


\section{Os dispositivos táticos}

No dia seguinte (1 de outubro de 331 a. C.), ao amanhecer, as trombetas macedónicas deram o sinal de alvorada e o exército de Alexandre desceu à planície, disposto a vencer ou morrer. Graças à qualidade das fontes utilizadas por Arriano, existe consenso acerca da disposição das tropas.

O exército persa ocupava uma frente muito larga. O comando da ala esquerda foi entregue ao general Besso (sátrapa da forte província da Bactriana), que se fazia acompanhar por uma unidade de perto de 8000 cavaleiros (cf. o n. ${ }^{\circ}$ I da gravura anexa). Ao seu lado direito, Besso tinha o apoio de um corpo de cavalaria do povo Daas (na costa leste do Mar Cáspio: n. ${ }^{\circ}$ II), de uma unidade de cavaleiros da Aracósia (n. ${ }^{\circ}$ III), de uma força mista de cavalaria e infantaria persas ( $n .^{\circ}$ IV), de um corpo de cavaleiros de Susa (a antiga capital da Pérsia: n. ${ }^{\circ} \mathrm{V}$ ) e, finalmente, de uma força montada da Cadúsia (nas proximidades do Mar Cáspio: n. ${ }^{\circ}$ VI). É possível que os contingentes montados sob o comando de Besso somassem perto de 15000 homens (fora os cavaleiros da unidade mista). À frente desta linha principal, Dario colocou 2000 cavaleiros da Cítia (n. ${ }^{\circ}$ VII), mais 1000 cavaleiros da Bactriana (n. ${ }^{\circ}$ VIII) e ainda um contingente de carros de guerra (talvez em número de 100: n. ${ }^{\circ}$ IX).

No centro da linha principal, estavam o próprio Dario com as tropas de cavalaria da Casa Real (talvez 1000 Huvaka: n. ${ }^{\circ}$ XI) e a infantaria pesada (n. ${ }^{\circ}$ XII, porventura 1000 Imortais, ou Melophoroi). Ladeando este 'núcleo duro', estavam dois corpos de infantaria mercenária grega, cada qual com perto de 1000 efetivos (n. ${ }^{\circ} \mathrm{X}$ e n. ${ }^{\circ}$ XIII). Daí para a direita (e sem que possamos quantificar os contingentes) havia ainda, nesta zona central do terreno, uma unidade de infantaria indiana (.${ }^{\circ}$ XIV), outra de infantaria da Cária (uma província da Ásia Menor: n. ${ }^{\circ}$ XV) e ainda uma outra unidade apeada composta por arqueiros Mardos (um povo do sul do Mar Cáspio: n. ${ }^{\circ}$ XVI). Atrás desta primeira linha do centro, Dario dispôs quatro corpos desmontados: um de Uxianos (povo da região entre Susa e Persépolis: n. ${ }^{\circ}$ XVII), outro de Babilónios (n. ${ }^{\circ}$ XVIII), outro formado por tribos do Mar Vermelho (n. ${ }^{\circ}$ XIX) e um último com Sitacenianos (povo vizinho dos Uxianos: n. ${ }^{\circ} \mathrm{XX}$ ). À frente do contingente da Casa Real, o Grande Rei colocou 

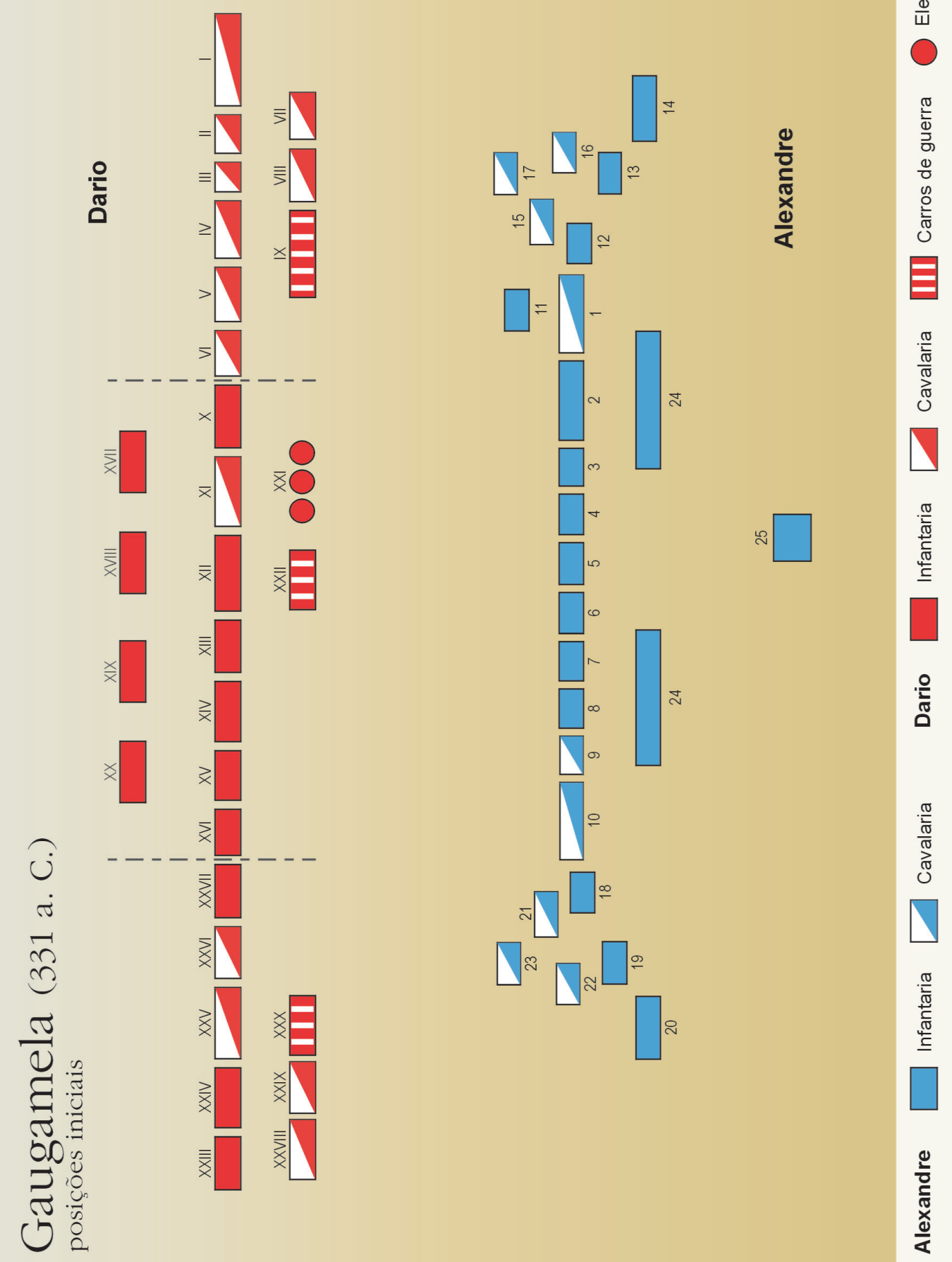

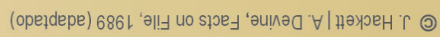


um núcleo de 15 elefantes (n. ${ }^{\circ}$ XXI) e, ao lado, um conjunto de 50 carros de guerra (n. $\left.{ }^{\circ} \mathrm{XXII}\right)$.

Ao comando da ala direita persa (cujos efetivos desconhecemos) estava Mazeu. Na linha principal foi colocada, à direita, uma unidade apeada de Sírios e de Mesopotâmios (n. ${ }^{\circ}$ XXIII); nela se posicionou Mazeu em pessoa, pois a tradição do combate antigo tendia a valorizar o flanco direito e a colocar o comandante no seu extremo. À sua esquerda, ficou uma força de infantaria da Média (n. ${ }^{\circ}$ XXIV), seguida por uma unidade com arqueiros montados da Pártia e dos Sacas (n. ${ }^{\circ} \mathrm{XXV}$ ); ao lado esquerdo desta, um contingente de cavalaria da Tapúria (na costa sul do Mar Cáspio) e da Hircânia (n. ${ }^{\circ}$ XXVI) e, ligando ao centro persa, um corpo de infantaria da Albânia (na costa oeste central do Cáspio) e sacesiana (na região do Cáucaso: n. ${ }^{\circ}$ XXVII). À frente desta linha principal, os Persas apresentavam, no flanco direito, duas unidades de cavalaria em que depositavam grandes esperanças: uma da Arménia (n. ${ }^{\circ}$ XXVIII) e outra da Capadócia (n. ${ }^{\circ}$ XXIX), mais um terceiro contingente de carros de guerra (em número, talvez, de 50:.$^{\circ} \mathrm{XXX}$ ).

Para além das suas tropas de elite (os Huvaka da Casa Real e os Imortais) e dos principais corpos de cavalaria catafractária munida de lanças compridas posicionados nas alas (os Bactrianos de Besso, e os Capadócios e Arménios de Mazeu), Dario confiava sobretudo na infantaria mercenária grega (combatendo à maneira dos hoplitas), que colocara no centro da linha, bem perto de si, e em duas armas muito especiais. Por um lado, os elefantes de guerra, que haviam sido transportados desde as fronteiras orientais da Pérsia e cuja visão aterrorizava os cavalos inimigos que nunca os tivessem enfrentado; transportavam arqueiros e dardeiros nos seus dorsos e dispunham de uma força que (pensava Dario) seria suficiente para romper a falange macedónica. Por outro lado, os 200 carros de guerra, equipados com lâminas de foice nas rodas; com terreno plano pela frente, Dario acreditava que estes carros (de que tinha fundado mais um grande corpo após Isso), lançados a grande velocidade, poderiam ser muito úteis numa fase inicial da batalha, abrindo clareiras na formação macedónica (fosse pelo medo que inspiravam, fosse em resultado do contacto direto) e deixando-a à mercê da cavalaria pesada. Devido à largueza da frente, o plano passaria 
por um envolvimento do adversário com tropas de cavalaria lançadas em ambos os flancos, manobra completada ao centro por um ataque frontal de forças selecionadas contra uma frente inimiga já de si debilitada pela ofensiva dos carros e dos paquidermes. O plano era hábil e adequado ao terreno; o principal risco advinha de ter de ser interpretado por um exército muito heterogéneo, envolvendo combatentes de vinte nacionalidades e que não estavam habituados a lutar em conjunto, sob a liderança do Grande Rei (tanto mais que os Persas tinham sofrido baixas pesadas em Isso). Para Dario, também não seria tarefa fácil comandar eficazmente um exército tão volumoso.

Quanto ao exército de Alexandre Magno (com cerca de 40000 peões e 7000 cavaleiros), o desafio consistia em adaptar-se à desproporção numérica (traduzida numa frente mais reduzida) e em conseguir acautelar a defesa (sobretudo nos dois flancos e na retaguarda) sem perder o ímpeto ofensivo. Assim, Alexandre colocou no centro da sua linha a infantaria pesada; da direita para a esquerda: os 3000 hipaspistai, sob a liderança de Nicanor (n. ${ }^{\circ}$ 2); e os seis "taxeis" da falange (os pezhetairoi), cada qual com 1500 homens. O comando do primeiro batalhão falangista (n. ${ }^{\circ}$ 3) foi entregue a Ceno, o do segundo (n. $\left.{ }^{\circ} 4\right)$ a Perdicas, o do terceiro (n. ${ }^{\circ}$ 5) a Meleagro, o do quarto (n. ${ }^{\circ}$ ) a Poliperconte, o do quinto (n. ${ }^{\circ}$ ) a Símias e o do sexto e último (n. ${ }^{\circ}$ 8) a Crátero. Guardando os flancos desta infantaria pesada, ficaram: à esquerda, um corpo de 600 cavaleiros gregos aliados, sob o comando de Erígio (n. ${ }^{\circ}$ ) e a forte unidade que reunia os 1800 cavaleiros da Tessália, liderada por Filipe (n. ${ }^{\circ}$ 10); à direita, os 1800 a 2000 Companheiros de Alexandre (n. ${ }^{\circ}$ ), organizados em oito esquadrões, ficando o agema real sob o comando de Alexandre e de Clito "o Negro", e os outros sete debaixo da liderança de Filotas (o filho de Parménio). A nata do exército macedónico estava quase toda nesta linha central, fitando de frente Dario e a sua tropa de elite.

Mais atrás, numa segunda linha, Alexandre posicionou dois grandes corpos (n. $\left.{ }^{\circ} 24\right)$ de infantaria grega (aliada e mercenários), cuja função seria a de, caso os Persas conseguissem envolver pelos flancos e atacar pela retaguarda, rodar e enfrentá-los. Atrás de tudo, foi colocado o trem de apoio 
macedónico (isto é, as bagagens), com um corpo de infantaria da Trácia para o proteger (n. $\left.{ }^{\circ} 25\right)$.

Até aqui, era tudo relativamente previsível. Em Gaugamela, foi na organização dos flancos que Alexandre concentrou o seu génio, colocando em cada um deles unidades escalonadas em três 'linhas potenciais', que, a qualquer momento, poderiam formar três azes viradas para fora a partir do centro. Quer dizer, Alexandre imaginou um sistema de guarda-flancos muito original e que lhe garantia alguma variedade de soluções. Assim, no flanco direito, junto aos Companheiros, foram colocados, numa linha mais recuada (toda ela desmontada), da esquerda para a direita e da frente para a retaguarda: metade dos Agrianes (um povo da Trácia, ou da Panónia, na atual Hungria), sob o comando de Átalo (n. $\left.{ }^{\circ} 12\right)$; um corpo de arqueiros macedónicos liderado por Brisão (n. $\left.{ }^{\circ} 13\right)$; e uma unidade de mercenários veteranos comandada por Cleandro (n. ${ }^{\circ}$ 14). Numa linha intermédia, e seguindo a mesma orientação, foram posicionados: os 600 lanceiros a cavalo (os Prodromoi, organizados em quatro esquadrões), comandados por Aretes (n. ${ }^{\circ}$ 15); e a cavalaria ligeira da Peónia, liderada por Aristão (n. ${ }^{\circ}$ 16). Numa linha mais avançada, Alexandre colocou a cavalaria mercenária de Menete (n. ${ }^{\circ}$ 17), com ordens para carregar sobre os Persas caso estes tentassem concretizar uma manobra de envolvimento do flanco direito. Por fim, em frente ao corpo dos Companheiros, foi instalada uma unidade que reunia o resto dos Agrianes e dos arqueiros macedónicos e também os dardeiros e arqueiros chefiados por Balacro (n. $\left.{ }^{\circ} 11\right)$.

Para o flanco esquerdo (comandado por Parménio), Alexandre concebeu o mesmo tipo de solução. Numa linha mais recuada e só com tropas desmontadas, ficaram: os dardeiros trácios às ordens de Sitalces (n. ${ }^{\circ} 18$ ); os arqueiros de Creta (n. ${ }^{\circ}$ 19); e a infantaria mercenária aqueia (n. ${ }^{\circ}$ 20). Na linha intermédia, posicionaram-se os cavaleiros gregos (ou trácios) aliados comandados por Cérano (n. $\left.{ }^{\circ} 21\right)$ e os cavaleiros odrísios, sob a liderança de Agatão (n. ${ }^{\circ}$ 22). Em posição mais avançada ficaram os cavaleiros mercenários de Andrómaco (n. ${ }^{\circ} 23$ ), a quem competiria carregar sobre as forças de Mazeu, caso estas tentassem um envolvimento do flanco esquerdo.

Portanto, Alexandre inventou para cada um dos flancos um dispositivo com uma guarda recuada disposta em ângulo de 45 graus. A simetria era 
quase total! Esta guarda de flanco, ou estas três linhas "em potencial" (como lhes chamam A. Devine e H. Modanez), tanto podiam ser mobilizadas para funções defensivas (e, nesse caso, o dispositivo assumiria quase a forma de um 'quadrado tático'), como para ações mais ofensivas. Sobrava, no entanto, um problema para Alexandre resolver: como, em concreto, criar condições para, não apenas suportar o ataque persa mas, ao mesmo tempo, desferir um golpe mortal sobre a hoste adversária. A reconstituição do combate mostra a forma genial como Alexandre superou o desafio.

\section{A batalha}

Tudo indica que foram os Macedónios que iniciaram a batalha, com um movimento pouco convencional dos Companheiros sobre o lado direito, numa trajetória oblíqua que, a não ser travada, teria arrastado o centro de gravidade do combate para a esquerda da posição persa. Dario ficou alarmado, pois, se a batalha resvalasse para fora do terreno que ele nivelara, os seus carros de guerra seriam inúteis e as possibilidades de envolvimento por esse lado ficariam comprometidas. Assim, o Grande Rei reagiu e mandou avançar os cavaleiros bactrianos ( $\mathrm{n} .^{\circ} \mathrm{VIII}$ ), provavelmente acompanhados por mais um ou outro contingente montado (o n. ${ }^{\circ}$ VII ou mesmo o n. ${ }^{\circ}$ II), com ordens para travar a progressão adversária. Perante isto, Alexandre ordenou uma carga da cavalaria mercenária de Menete (n. ${ }^{\circ}$ 17) em apoio do grupo da frente. Porém, por serem demasiado poucos (talvez uns 400 homens), foram facilmente repelidos e viram-se obrigados a recuar. Isto levou Alexandre a injetar mais forças na linha da frente, mandando avançar os Prodromoi de Aretes (n. $\left.{ }^{\circ} 15\right)$ e a cavalaria peónia de Aristão (n. ${ }^{\circ} 16$ ), com o apoio da infantaria mercenária veterana de Cleandro (n. ${ }^{\circ}$ 14). Face a este reforço da capacidade de combate dos Macedónios no flanco direito, Besso, que liderava a ala esquerda persa, foi obrigado a enviar os restantes cavaleiros bactrianos (n. ${ }^{\circ}$ I) para a linha da frente. Esta decisão avivou o combate naquela zona do terreno.

Enquanto isso (as fontes são confusas quanto à ordem dos ataques), Dario lançava a ofensiva dos carros de guerra (n. ${ }^{\circ}$ IX e n. ${ }^{\circ}$ XXII) contra o 
centro-direita macedónico. A operação foi mal sucedida: a infantaria dos Agrianes e os dardeiros de Balacro (n. ${ }^{\circ} 11$ ), que protegiam a frente dos Companheiros, neutralizaram a investida, disparando sobre os condutores, correndo ao lado dos carros para cortar os arreios ou apoderar-se das rédeas e liquidando os combatentes que tombavam. Alguns carros conseguiram furar esta barreira, mas os Macedónios abriram alas e deixaram-nos passar, acabando depois a retaguarda de Alexandre por capturá-los. Quanto aos elefantes, sempre pouco fiáveis em combate, nem sequer ousaram enfrentar a muralha de sarissas macedónicas, pelo que foram inúteis.

Entretanto, na ala direita, as forças de Alexandre, já reforçadas pela infantaria dos Agrianes (n. ${ }^{\circ}$ 12) e pelos arqueiros macedónicos de Brisão (n. $\left.{ }^{\circ} 13\right)$, começavam a levar vantagem. Besso fazia o que podia, mas o seu esforço para manter a luta equilibrada acabaria por ter um preço elevadíssimo: em resultado do movimento constante das tropas persas para o lado exterior do terreno, abriu-se uma brecha no centro-esquerda, que Dario não conseguiu colmatar. Era a oportunidade por que Alexandre aguardava: num ápice, formou os oito esquadrões dos Companheiros (n. $\left.{ }^{\circ} 1\right)$ em forma de seta e, com o apoio da infantaria dos bipaspistai (n. ${ }^{\circ}$ 2) e de quatro batalhões da falange (n. 3 a n. ${ }^{\circ}$ 6), atacou diretamente a posição de Dario (n. $\left.{ }^{\circ} \mathrm{XI}\right)$ ! O Grande Rei, com a infantaria mercenária grega (n. ${ }^{\circ} \mathrm{X}$ e n. ${ }^{\circ}$ XIII) e com os Imortais (n. ${ }^{\circ}$ XII) pressionados pela aproximação da infantaria pesada inimiga, não tinha tropas à altura de travar o avanço dos Companheiros, cuja cunha se aproximava velozmente, semeando o caos no centro-esquerda persa (vide a gravura anexa). Dario viu-se obrigado a escolher entre fugir ou morrer. Depois de o condutor do seu carro ter sido abatido por um dardo, optou por se pôr em fuga num cavalo, sem querer saber do que se passava no resto do campo de batalha, nomeadamente no flanco direito dos Persas.

Aqui, a situação era bastante diversa. Mazeu avançara a cavalaria da Arménia e da Capadócia (n. ${ }^{\circ}$ XXVIII e n. ${ }^{\circ}$ XXIX) e estava em ponto de criar sérias dificuldades a Parménio. Conforme o previsto, a guarda do flanco esquerdo macedónico reagira e a cavalaria mercenária de Andrómaco (n. ${ }^{\circ}$ 23), juntamente com a unidade de cavalaria aliada de Cérano ( ${ }^{\circ}{ }^{\circ} 21$ ) e os cavaleiros odrísios de Agatão (n. ${ }^{\circ} 22$ ), tinha enfrentado o perigo, com 


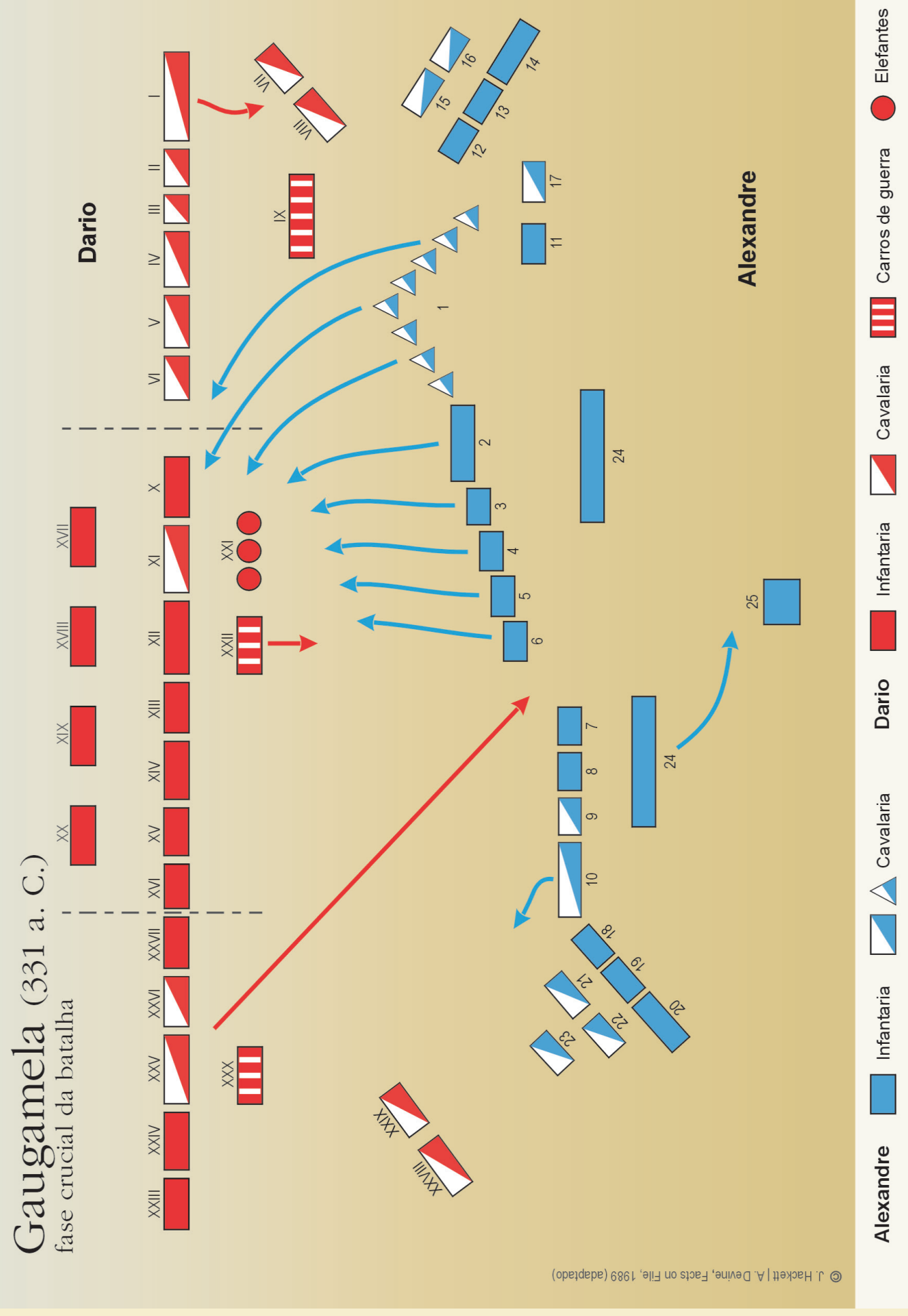


o apoio dos corpos de infantaria da 'linha em potencial' mais recuada (os dardeiros trácios, os arqueiros cretenses e a infantaria mercenária aqueia: n. ${ }^{\circ} 18$ a n. ${ }^{2}$ 20). Porém, a resistência revelava-se difícil e antevia-se ser indispensável a intervenção da cavalaria tessálica de Filipe (n. ${ }^{\circ}$ 10) para a sustentar.

Mas o pior, na perspetiva de Alexandre, é que os dois batalhões da falange posicionados mais à esquerda (o comandado por Símias, n. ${ }^{\circ}$, e o liderado por Crátero, n. ${ }^{\circ}$ 8) não tinham podido acompanhar o movimento dos outros taxeis no seu processo de ataque à posição de Dario! Ou por não terem sido tão rápidos, ou por se terem apercebido das dificuldades da ala esquerda macedónica, o certo é que se abrira uma brecha na formação de Alexandre. Aproveitando o facto, alguma cavalaria persa (talvez da linha recuada de Mazeu: n. ${ }^{\circ}$ XXVI), acompanhada por contingentes dos Partos ( $n .^{\circ} \mathrm{XXV}$ ), investiu por essa brecha, cortando a falange dos pezhetairoi em dois. Felizmente para Alexandre, tal força, talvez por ser muito heterogénea, não teve o discernimento suficiente para atacar as tropas macedónicas a partir de trás, optando por se lançar contra o trem de apoio vigiado pela infantaria trácia (n. ${ }^{\circ}$ 25), na esperança de libertar alguns prisioneiros ou de fazer algum saque. Assim, acabou por ser repelida pela infantaria grega colocada na retaguarda (n. $\left.{ }^{\circ} 24\right)$.

Por esta altura, o rei macedónico tinha-se lançado em perseguição a Dario, cuja captura considerava essencial. Porém, a situação na ala esquerda macedónica inspirava cuidados e Parménio terá então enviado um mensageiro a Alexandre, com um pedido de socorro. A maioria dos autores admite que o monarca (mau grado ter de abrir mão da captura de Dario) terá mesmo vindo em socorro de Parménio. Neste seu movimento de regresso, cruzando o campo de batalha, Alexandre terá chocado com a cavalaria persa e parta que acabara de ser repelida no seu ataque ao trem de apoio macedónico, circunstância inesperada e que gerou um violento recontro, no qual acabaram por perecer alguns dos Companheiros. Por fim, Alexandre lá terá conseguido alcançar o seu flanco esquerdo. Quando isso sucedeu, porém, já a situação estava controlada: primeiro, porque a intervenção da forte cavalaria tessálica comandada por Filipe (n. $\left.{ }^{\circ} 10\right)$ equilibrara de novo o combate; segundo, porque se tinha espalhado a notícia da fuga precoce de Dario, o que incitara a tropa de Mazeu a debandar... 
A sorte do combate estava traçada e a vitória já não podia escapar a Alexandre. Triunfo suado, com algumas centenas de baixas, fora os cavalos que foram abatidos ou que tombaram por esgotamento durante a perseguição. Nesta última fase, a chacina deve ter sido tremenda, pois os Persas tinham o rio Lico entre o campo de batalha e a cidade de Arbela (para onde se dirigiram os fugitivos): a travessia deste curso de água parece ter sido calamitosa para os homens de Dario, com a ponte congestionada e muitos afogamentos na corrente rápida do rio. No dia seguinte, Alexandre chegaria a Arbela, por onde Dario também já passara na sua fuga a galope. Apoderou-se então dos equipamentos e dos tesouros pessoais do Grande Rei, que bem úteis lhe viriam a ser no resto da campanha asiática.

Gaugamela foi a mais espetacular e decisiva de todas as vitórias de Alexandre Magno. Nunca mais o exército persa conseguiu organizar-se como força expressiva, contra os Macedónios ou os Gregos. Em primeiro lugar, convém destacar que os dois fatores mais importantes no triunfo de Alexandre foram, por um lado, a resistência sofrida da ala esquerda macedónica, comandada por Parménio, e, por outro, o ataque fulminante dos Companheiros. Existe alguma controvérsia em torno da manobra inicial de Alexandre, ou seja, em torno daquele movimento oblíquo que quase colocava a ala direita macedónica fora do campo de batalha. Convém recordar que a manobra de ataque oblíquo, expondo uma das alas e retendo a outra o mais possível, já era conhecida desde Epaminondas. No fundo, tratava-se de evitar o contacto com toda a linha da frente em simultâneo, apostando as fichas quase todas num dos flancos e concentrando neste as melhores forças. Se tudo corresse bem, seria a partir dessa ala avançada que depois se lançaria um ataque poderoso, em cunha, sobre um ponto sensível da linha adversária, tentando obter aí uma vantagem decisiva.

Ao desviar o seu avanço para a direita, em diagonal, Alexandre (que contava com oficiais competentes e dedicados) não só tentou surpreender os Persas como permitiu que a sua ala direita e uma parte do centro colidissem com o adversário nos termos o mais favoráveis possível, pesem embora os riscos que a manobra comportava para a ala esquerda macedónica, que ficou mais vulnerável (porque mais entregue a si própria) a uma investida 
em força da cavalaria ao serviço de Mazeu. É difícil dizer até que ponto esta manobra foi prevista por Alexandre. As fontes não são explícitas e é possível que a própria dinâmica do combate tenha acentuado esse efeito de diagonal avançada sobre o lado direito que a linha de Alexandre produziu. Seja como for, esta evolução foi favorável aos planos macedónicos, uma vez que forçou os adversários a movimentos imprevistos (deslocação do combate para o lado esquerdo dos Persas), o que originou a abertura de uma brecha decisiva. Ao avistá-la, e tivesse ela correspondido ao seu plano original ou surgido em consequência de espaços abertos pelo desenrolar do combate, Alexandre imediatamente a explorou, dispondo os esquadrões dos seus Companheiros em seta e avançando na direção de Dario, sustentado pela progressão dos hipaspistai e de quatro batalhões da falange.

É isto que mais impressiona no comportamento militar de Alexandre: a sua capacidade para explorar uma pequena oportunidade, para passar à ofensiva; a noção do tempo exato para lançar a carga decisiva (em jeito de Blitzkrieg, como sugeriu Rob Rice), mesmo se, no resto do terreno, as suas forças sentiam grandes dificuldades (recorde-se que, com aquele movimento ofensivo, a falange macedónica ficou partida em duas, enquanto a ala esquerda de Parménio dava sinais de poder soçobrar). Ao aplicar a sua força máxima num alvo selecionado do inimigo, Alexandre desestabilizou todo o exército persa e obrigou à fuga prematura de Dario, o que acabaria por ter resultados trágicos no ânimo do exército oriental.

Um último fator diz respeito à forma como Alexandre preveniu e resolveu os principais problemas que the foram colocados por Dario: por um lado, com o sistema de guarda-flancos que concebeu, conseguiu evitar o envolvimento pelas laterais, uma especialidade da arte militar persa; por outro, neutralizou bem os carros de guerra, que acabaram por não ter influência no desenrolar do combate. Ou seja, os Macedónios defenderam bem e, ao fazê-lo, deram tempo a Alexandre para lançar o ataque decisivo na primeira grande oportunidade que lhe surgiu pela frente. Como se vê, a vitória ficou sobretudo a dever-se à cavalaria dos Companheiros (foi ela que retirou do terreno o general inimigo), e essa é precisamente a "matriz macedónica" (a expressão é de H. Modanez) da arte militar helenística que haveria de dar cartas no futuro. 


\section{Conquistar o Império}

Depois de deixar Arbela, Alexandre marchou em direção à Babilónia, onde foi bem recebido. De forma inteligente, optou por manter Mazeu como sátrapa desta província, embora colocando-o sob tutela macedónica. A mesma política foi posta em prática com outros governadores. A partir daqui, como lembra J. Keegan, Alexandre tinha três possibilidades: a) retirar para as linhas do Eufrates, deixando a força económica e militar da Pérsia destroçada; b) parar, como faria mais tarde um imperador romano, Trajano, contentando-se com as planícies férteis da Mesopotâmia; c) ou prosseguir na senda da conquista do Império Persa. Alexandre optou pela terceira hipótese e dirigiu a sua 'linha de controlo' continuamente para oriente.

Enfrentando a neve que cobria já os caminhos naquele inverno de 331-330 a. C., Alexandre avançou para a Ásia Central e começou por alcançar Persépolis, a capital e a cidade mais rica do Império. Aqui, o rei macedónico apoderou-se de um imenso tesouro, que Diodoro da Sicília estima em 120000 talentos de ouro e de prata. Em Persépolis, Alexandre promoveu jogos e sacrifícios, mas também deixou que a festa ficasse para sempre manchada por um episódio de embriaguez coletiva que irrompeu durante um banquete e que redundou no incêndio do fabuloso palácio régio. A seguir, Alexandre rumou a Ecbátana, de onde enviou para suas casas muitos dos aliados tessálicos e gregos, tendo igualmente procedido a nomeações entre os Persas, como forma de cativar a nobreza oriental, de serenar os ânimos e de reforçar a sua influência num mundo que ainda lhe era estranho e, em grande medida, hostil.

Entretanto, Dario fora acolhido por Besso, o sátrapa da Bactriana. Todavia, depois da sua fuga em Gaugamela, a autoridade de Dario ficara reduzida a cinzas. Três sátrapas (Besso, Barsantes e Nabazanes) conspiraram contra Dario, que foi deposto e aprisionado, vindo mais tarde a ser apunhalado e abandonado moribundo em pleno deserto, onde Alexandre o recolheu (oito ou nove meses depois de Gaugamela) e enviou para Persépolis. Alexandre tornou-se então o novo Grande Rei da Pérsia, pondo termo à dinastia dos Aqueménidas (isto apesar de, entre os Gregos, continuar a intitular-se begemon, isto é, líder da aliança contra os Persas). O direito de 
conquista sobrepunha-se ao direito ao trono conferido pela legitimidade ou pela ascendência. A lança macedónica conquistara a terra persa e essa seria doravante a fonte do seu poder e do seu direito. De Ecbátana, Alexandre avançou para leste e entrou num mundo totalmente ignorado dos Gregos. Com o apoio dos Bactrianos, Besso autoproclamara-se Rei da Pérsia e Alexandre viu-se também forçado a pacificar parte da satrapia de Barsantes; penetrando pela região da Drangiana, eliminou o governador rebelde.

Estava-se então no ano de 330 a. C. e foi nesta época que Alexandre teve de lidar com uma tentativa de usurpação do trono perpetrada por um desconhecido, com o apoio de Amintas e de um tal Demétrio e contando com o silêncio ensurdecedor de Filotas (o segundo homem no comando dos Companheiros). Alexandre não perdoou e Filotas foi executado, seguindo-se-lhe o pai, o velho Parménio, pois o novo Grande Rei não gostava de correr riscos desnecessários... Ainda no mesmo ano, ocorreria o assassinato de Clito "o Negro" pelo próprio Alexandre, no termo de uma acalorada discussão à mesa, com demasiado vinho à mistura, ato de que Alexandre se arrependeria amargamente.

Alexandre mandou depois subjugar as satrapias da Carmânia (nas proximidades do Golfo Pérsico) e da Gedrósia (banhada pelo Mar Arábico, no atual Paquistão). Restava-lhe submeter a Aracósia, mais a norte, dominar Besso (que acabou por ser aprisionado e entregue a Alexandre, em meados de 329 a. C.), conquistar os últimos fortes persas que não the eram leais e controlar algumas revoltas 'nacionais'. Para o efeito, montou (em 329-328 a. C.) uma rede de comunicações fortificada no extremo nordeste do Império (na região de Samarcanda, na Sogdiana, atual Usbequistão), uma forma de defesa muito eficaz contra as táticas dos povos do deserto, pautadas pelo esgotamento das forças adversárias e por investidas inconsequentes. Em resultado desta estratégia, Alexandre acabaria por derrotar quatro generais persas, tendo depois - como forma de prevenir novas revoltas locais - casado com a filha de um deles: Roxana, filha de Oxiartes, de quem veio a ter um filho póstumo (Alexandre IV, executado antes de chegar à idade adulta, juntamente com a mãe).

Assim, Alexandre cumpriu as missões que se propôs no contexto da conquista do Império Persa, mas nessa altura começava já a ser visível o 
desconforto causado pela introdução no protocolo macedónico de algumas práticas asiáticas, como o ajoelhamento. Este ambiente parece ter estado na origem da Conspiração dos Pajens, chefiada por Calístenes, sobrinho de Aristóteles e historiador oficial da expedição. A intriga acabou em novo banho de sangue, liquidando mais um daqueles que eram, à partida da Europa, os homens mais próximos do rei macedónico.

Com o exército refrescado por algumas reformas (p. ex., a criação das hiparquias no seio dos Companheiros: quatro esquadrões sob o comando direto de Alexandre e outros quatro sob o de Heféstion, talvez para controlar melhor as revoltas internas do exército) e também pela chegada de um batalhão europeu (comandado por Clito "o Branco") e pela criação de um novo contingente resultante do recrutamento e treino de forças nativas, Alexandre tomou então a decisão de avançar para a Índia desconhecida!

Em 327 a. C., partiu da Bactriana rumo ao rio Indo, acompanhado por uma pequena manada de elefantes (que nunca chegaria a usar) e contando com um certo apoio da população. Atravessou a cordilheira do Hindu-Kush perto de Cabul, cruzou o Indo em 326 a. C. e penetrou então numa Índia com os rajás divididos e sem grande capacidade para lhe resistir. Com exceção do rei Poro, que o enfrentou nesse mesmo ano, na última batalha de Alexandre, travada nas margens do rio Hidaspes (atual rio Jhelum, no Paquistão). Foi um estranho combate, com os cavalos macedónicos a recusarem aproximar-se dos 200 elefantes indianos. Alexandre viu-se obrigado a ensaiar uma manobra simulada que lhe permitiu liquidar primeiro a cavalaria de Poro (entalada entre as hiparquias de Alexandre e de Ceno, que manobrara na retaguarda adversária), após o que a falange macedónica (com algum apoio nos flancos por parte de infantaria ligeira, armada com arcos e com dardos) conseguiu levar a melhor sobre a infantaria indiana e sobre os paquidermes que a acompanhavam. Poro foi aprisionado durante a perseguição, mas Alexandre apreciara a sua ousadia e decidiu mantê-lo como rei, embora colocando-o sob tutela macedónica.

Nas imediações do campo de batalha, Alexandre fundou então mais duas cidades com o seu nome: Alexandria Niceia, em comemoração do triunfo; e Alexandria Bucéfala, em honra do seu cavalo Bucéfalo, que morrera em combate. Depois, liderou ainda algumas campanhas e deu sinais de querer 
continuar a avançar na direção do Ganges. Contudo, chegados ao rio Beas (antigo Hífasis), cerca de 27000 quilómetros depois de terem pisado a Ásia, esgotados por oito anos de campanhas quase ininterruptas - escalando montanhas com cordas, atravessando rios com peles insufladas, enfrentando a natureza e as tribos hostis, suportando chuvas constantes e monções que desconheciam -, porventura amedrontados também com as notícias acerca de uns elefantes enormes, certamente desejosos de voltar às suas terras, os soldados recusaram-se a prosseguir. E, desta vez, o grande Alexandre não levou a melhor... Ainda completou um pouco as suas conquistas na região (numa das operações, escalou a muralha de uma cidade e quase morreu, vítima de um projétil que lhe acertou no peito), mandou erguer 12 altares em honra dos deuses do Olimpo e, depois, rumou a ocidente. Em 325 a. C., atravessou (com grandes dificuldades logísticas) o deserto da Gedrósia e, em inícios de 324 a. C., alcançou Susa, colocando um ponto final na mais impressionante campanha militar que a memória dos homens conservou até aos nossos dias.

Chegara a hora do repouso dos guerreiros e Alexandre - na esperança de consolidar o seu projeto de unificação - aproveitou a ocasião para promover o casamento de 10000 dos seus homens com as respetivas concubinas e ainda o de 80 oficiais, incluindo ele próprio, com mulheres da aristocracia persa. No entanto, os Macedónios mostravam-se hostis a medidas cada vez mais orientalizantes (como o uso da vestimenta persa por Alexandre) e não se mostraram capazes de aceitar a introdução de nobres persas no esquadrão real, ou o alistamento de asiáticos nas hiparquias. Também o esforço de inserção no exército de 30000 jovens persas que tinham sido equipados e treinados para lutar como os Macedónios provocou um motim em Ópis, perto de Babilónia, que Alexandre reprimiu com um misto de diplomacia e brutalidade.

Ainda assim, Alexandre não deixava de fazer novos planos. Por um lado, desejava averiguar a possibilidade de estabelecer uma rota marítima entre a Índia e a Babilónia, pelo que Nearco tinha sido enviado com a missão de explorar o Golfo Pérsico. Por outro, não dava as suas conquistas por terminadas, pensando talvez numa campanha no Norte de África, dirigida contra Cartago, com retorno à Grécia através da Espanha e da Itália. O destino, 
todavia, não lhe permitiu completar nenhum desses projetos. Atacado por uma febre violenta (talvez malária), Alexandre acabou por falecer em Babilónia no dia 10 de junho de 323 a. C., não tinha ainda completado 33 anos.

À morte daquele que tinha conseguido concretizar o velho sonho dos Gregos, o Império seria fragmentado entre os seus antigos generais, dando origem à formação dos "reinos helenísticos". Sobretudo os Ptolomeus, no Egito, e os Selêucidas, na parte oriental do império, tentaram continuar a obra de Alexandre e manter viva a marca do helenismo. Trinta anos depois de Alexandre ter atravessado o Helesponto, a língua grega era utilizada (nos tribunais, na literatura, na política) nos países desde as costas do Mar Egeu até às margens do rio Indo, e também no Egito. Graças a isso, o cristianismo avançará mais facilmente na Ásia Menor, na Síria e no Egito. Boa parte da ciência e da filosofia hindus, tal como da ciência dos Árabes, sofreu influência grega. Alexandria, a cidade fundada por Alexandre no Egito, tornou-se com Ptolomeu a capital deste reino e foi a partir dessa dinastia, que então teve início e que durou até à rainha Cleópatra (que morreu com Marco António, após a batalha naval de Ácio, em 31 a. C.), que se tornou a capital do saber, com uma forte marca helénica. Já em época romana, continuava a falar-se grego em Alexandria, pois a presença da comunidade grega era aí muito forte (e perdurou, aliás, até aos nossos dias). Muito para além de Alexandre, em época tardo-helenística e romana, os nomes mais sonantes da Literatura Grega deixaram de ser gregos de origem; são sobretudo asiáticos, como Luciano de Samósata, Cáriton de Afrodísias, Xenofonte de Éfeso, entre outros. Estes homens falavam um grego próprio de (quase) nativos e conheciam bem a tradição cultural helénica. Foram, portanto, educados nessa base cultural séculos passados sobre a conquista macedónica.

Ou seja, a marca de Alexandre - talvez o general que mais influenciou a história militar, a par de Napoleão - perdurou muito para além dos seus dias. Quando Roma e Cartago ocuparem o palco, muitos dos principais conceitos militares helenísticos estarão bem presentes: a ideia de coesão das formações militares (fala-se mesmo em "legião-hoplita"!); a noção da disciplina e do dever cívico; a colocação do heroísmo individual ao serviço do coletivo; a valorização da cavalaria e da manobra envolvente (espécie de síntese das tradições militares helénica e do Médio Oriente, que Aníbal 
Barca e Cipião "o Africano" reinventarão); o uso de elefantes; e tantos outros. Curiosamente, foi um mercenário espartano quem reorganizou o exército terrestre cartaginês, em meados do séc. III a. C., e não o fez de qualquer maneira: Xantipo, assim se chamava ele, ligou a tradição militar grega à tradição militar cartaginesa, mas fê-lo através das lições de Filipe II e de... Alexandre Magno!

\section{Fonte principal}

Arriano, Anabasis Alexandri. Utilizámos a tradução inglesa de Aubrey de Sélincourt: Arrian, The Campaigns of Alexander, Penguin Books, 1971.

\section{Leituras-base}

Henrique Modanez de Sant'Anna, Alexandre Magno: a paixão da guerra. Coimbra, Imprensa da Universidade de Coimbra, 2010.

John Hackett (editor, com ilustrações de Peter Connolly), Warfare in the Ancient World. Nova Iorque, Oxford, Sidney, Facts on File, 1989. Com colaborações de John Lazenby ("A arte da guerra dos Hoplitas": pp. 54-81), de Nick Secunda ("Os Persas": pp. 82-103) e de Albert Devine ("Alexandre Magno": pp. 104-129), entre outros.

\section{Leituras recomendadas}

Arther Ferrill, The Origins of War. From the Stone Age to Alexander the Great. Londres, Thames \& Hudson, 1985.

Edward Creasy, Quinze Batalhas Decisivas da Humanidade. De Maratona a Waterloo. Trad. port., Lisboa, Ed. Ślabo, 2008 (ed. orig.: 1851). Prefácio de José Varandas.

F. E. Adcock, The Greek and Macedonian Art of War. Berkeley, Los Angeles, Londres, University of California Press, 1957.

John Keegan, Uma História da Guerra. Trad. port., Lisboa, Ed. tinta-da-china, 2009 (ed. orig.: 2006).

José Ribeiro Ferreira, A Grécia Antiga. Sociedade e Política. 2. ${ }^{a}$ ed., Lisboa, Edições 70, 2004 (ed. orig.: 1999).

José Ribeiro Ferreira e Delfim F. Leão, Dez Grandes Estadistas Atenieneses. Lisboa, Edições 70, 2010.

Maria Helena da Rocha Pereira, Estudos de História da Cultura Clássica, I. Cultura Grega. 10. ${ }^{a}$ ed., Lisboa, Fundação Calouste Gulbenkian, 2006 (ed. orig.: 1964).

Rob S. Rice, "Gaugamela, 331 BC", in Battles of the Ancient World, 1285 BC - AD 451. From Kadesh to Catalunian Field. Londres, Amber Books, 2007 (pp. 82-89).

Victor Davis Hanson, The Western Way of War. Infantry Battle in Classical Greece. Berkeley, Los Angeles, Londres, University of California Press, 2000 (ed. orig.: 1989). 


\section{CAPÍTULO 2}

\section{CANAS (216 A. C.): ROMA E CARTAGO \\ - A GUERRA PELO MEDITERRÂNEO}

\section{Roma e Cartago}

Fundada, segundo a tradição, em 753 a. C., Roma foi durante séculos uma pequena comunidade e praticava uma guerra de escala muito reduzida. No séc. vi a. C., Roma ficou sob a dominação dos Etruscos, mas a fundação da Liga Latina e a ajuda dos Gregos que haviam colonizado a costa sul do Lácio permitiram expulsar os Etruscos e rasgaram novos horizontes à cidade de Rómulo. Em 280 a. C., Roma controlava já a Península Itálica, depois de vencer também os Samnitas, os Úmbrios e os Celtas do Adriático. Poucos anos mais tarde, Roma submeteria ainda as colónias gregas da Itália peninsular. A escala da guerra praticada pelos Romanos foi aumentando, ao mesmo tempo que a cidade (que desde 509 a. C. se tornara uma República) revelava uma invulgar capacidade integradora de povos estranhos. O destino parecia anunciar que em breve Roma deixaria de ser uma potência meramente peninsular...

Na mesma época, na costa do Norte de África, em território que pertence hoje à Tunísia, existia porém uma cidade capaz de rivalizar com Roma. Falamos de Cartago, cidade que Fenícios oriundos de Tiro (no atual Líbano) haviam fundado nos finais do séc. VIII a. C. O talento comercial dos Fenícios (a que os Romanos chamavam "Poeni", isto é, Púnicos) era excecional, assim como a sua capacidade para explorar os férteis terrenos 
agrícolas norte-africanos. O resultado foi que, na década de 280 a. C., Cartago se impunha como uma cidade riquíssima, controlando o comércio no Mediterrâneo ocidental e dominando as costas de África e da Hispânia, assim como as ilhas da Sicília, da Sardenha e da Córsega, entre outras. Em comparação com o de Roma, o território cartaginês tinha então, aproximadamente, a mesma extensão, mas era muito menos densamente povoado, pelo que os seus recursos humanos eram mais limitados.

\section{As Guerras Púnicas}

Em 265 a. C., Roma decidiu executar a sua primeira grande intervenção externa. Fê-lo na Sicília, uma ilha que se situava na área de influência de Cartago... Tal foi a origem da Primeira Guerra Púnica, que haveria de prolongar-se de 264 a 241 a. C. Esta guerra traduziu-se sobretudo em combates navais à volta da Sicília, mas em 256 a. C. os Romanos optaram por invadir o Norte de África e ameaçar diretamente a cidade de Cartago. Esta respondeu à letra e daí resultou um combate terrestre que foi favorável às tropas púnicas. No mar, porém, a guerra revelava-se favorável aos Romanos, pelo que o resultado do conflito permanecia incerto. Até que, em 241 a. C., uma batalha naval travada ao largo das Ilhas Egates (a oeste da Sicília) decidiu a guerra a favor dos Romanos. Cartago foi obrigada a render-se, a abdicar da Sicília e a pagar uma choruda indemnização.

Porém, nem todos os Cartagineses tinham aceitado o veredito com resignação. O comandante do exército púnico na Sicília, um aristocrata e alto magistrado chamado Amílcar Barca, acreditava que Cartago poderia ter continuado a enfrentar os Romanos até à vitória final. E Cartago bem precisava de um comandante exímio, pois entretanto Roma tinha aproveitado os conflitos internos da sua rival ("Guerra Mercenária") para tomar a Sardenha e ameaçar de novo a principal cidade púnica com a perspetiva de uma guerra cruel. Este episódio, provavelmente ocorrido em 237 a. C., humilhara os Cartagineses, forçados a uma segunda capitulação e ao pagamento de uma indemnização adicional de 1200 talentos, o que avolumou as tensões e os rancores dos Púnicos relativamente aos Romanos... 


\section{Aníbal Barca}

Em 237 a. C., Amílcar Barca foi nomeado comandante da província cartaginesa da Hispânia. O seu forte ressentimento contra os Romanos levou-o a conceber aí um programa expansionista de grandes dimensões. Não teve, porém, tempo para o executar, pois a morte surpreendeu-o cedo demais, em 229 a. C. Sucedeu-lhe inicialmente o cunhado, Asdrúbal, e depois (em 221 a. C.), quando este foi assassinado, o filho, Aníbal Barca, uma das personagens mais extraordinárias da história do mundo antigo.

Aníbal dedicou-se por inteiro à construção, na Hispânia, de um exército à medida dos melhores sonhos do pai. A expansão cartaginesa na Hispânia (com a base principal situada no litoral leste, em Nova Cartago, atual Cartagena) permitiu-lhe aceder a muito metal precioso e recrutar bons guerreiros entre as tribos hispânicas. A coerência da sua política marcial e a fidelidade dos seus soldados à família dos Barca ajudaram Aníbal a consolidar rapidamente o seu projeto. E, assim, em 220 a. C., já ele se sentiu com força suficiente para apoiar uma tribo aliada numa disputa na cidade costeira de Sagunto (próxima da atual Valência), que mantinha uma boa relação com Roma. Apesar de intimado pelo Senado romano a levantar o cerco, Aníbal insistiu e, ao fim de oito meses de assédio, forçou Sagunto a capitular e converteu a respetiva população à escravatura. Roma protestou, mas Cartago recusou-se a castigar o jovem Barca. Mais não foi preciso para que Roma declarasse guerra a Cartago, dando assim início à Segunda Guerra Púnica (218-201 a. C.).

\section{A longa marcha}

Aníbal entregou-se então à tarefa de organizar minuciosamente a fabulosa expedição que Amílcar Barca idealizara: invadir a Itália por terra, a partir da Hispânia cartaginesa! Ou seja, atravessar o rio Ebro (que passa em Saragoça e desagua a sul de Barcelona, um rio que os Romanos tinham imposto a Asdrúbal como limite para a expansão cartaginesa na Hispânia), passar os Pirenéus, entrar na Gália, transpor os Alpes e alcançar depois o 
Norte de Itália. Era um projeto arriscadíssimo, bem à medida de um comandante genial. Mas era também uma alternativa lógica, uma vez que o enfraquecimento dos recursos navais púnicos (embarcações e bases marítimas) na sequência da guerra contra Roma, a par dos seus limitados recursos humanos (indispensáveis para preencher as imensas fiadas de bancos dos vasos de guerra movidos a remos), não recomendavam uma iniciativa naval contra os Romanos. E, na Gália, Aníbal esperava poder contar com o apoio de diversas tribos celtas em guerra contra os Romanos. De qualquer forma, a estratégia cartaginesa surpreendeu Roma, que estava habituada a uma atitude mais defensiva da sua rival.

A longa marcha iniciou-se em Nova Cartago, no final da primavera de 218 a. C., com mais de 100000 soldados (dos quais 90000 peões e 12000 cavaleiros) e 37 elefantes. Não temos grandes descrições sobre esta jornada épica, mas decerto foi dificílima devido aos obstáculos naturais, à imensidão do exército (difícil de controlar e de alimentar) e, claro, aos povos hostis que iam encontrando pelo caminho e que havia que combater. Certo é que, em novembro de 218 a. C., o que restava do exército cartaginês (perto de 20000 peões e 6000 cavaleiros, ou seja, apenas uma quarta parte dos que haviam partido da base hispânica cinco meses antes) alcançava o Norte de Itália (atual região de Turim). Aníbal conseguira a sua primeira vitória e depressa tratou de engrossar a sua hoste (repleta de soldados experientes e leais) com grande número de guerreiros das tribos gaulesas em luta contra os Romanos.

Entretanto, Roma fizera também os seus preparativos para a Segunda Guerra Púnica. Esperando uma sequência de combates na área mediterrânica, o Senado distribuíra os dois cônsules eleitos em 218 a. C. de forma bastante lógica: Tito Semprónio Longo fora enviado para a Sicília, com o objetivo de invadir o Norte de África; e a Públio Cornélio Cipião fora ordenado que avançasse para a Hispânia, para aí atacar Aníbal Barca. E foi justamente Cipião quem, estando em Marselha a preparar o embarque das suas tropas para a Península Ibérica, descobriu que Aníbal e o seu volumoso exército se preparavam já para cruzar o rio Ródano, a caminho dos Alpes (cuja travessia viria a fazer-se em perto de 15 dias). Tentou ainda enfrentar o adversário, mas já era demasiado tarde. Contactado o Senado, que recebeu 


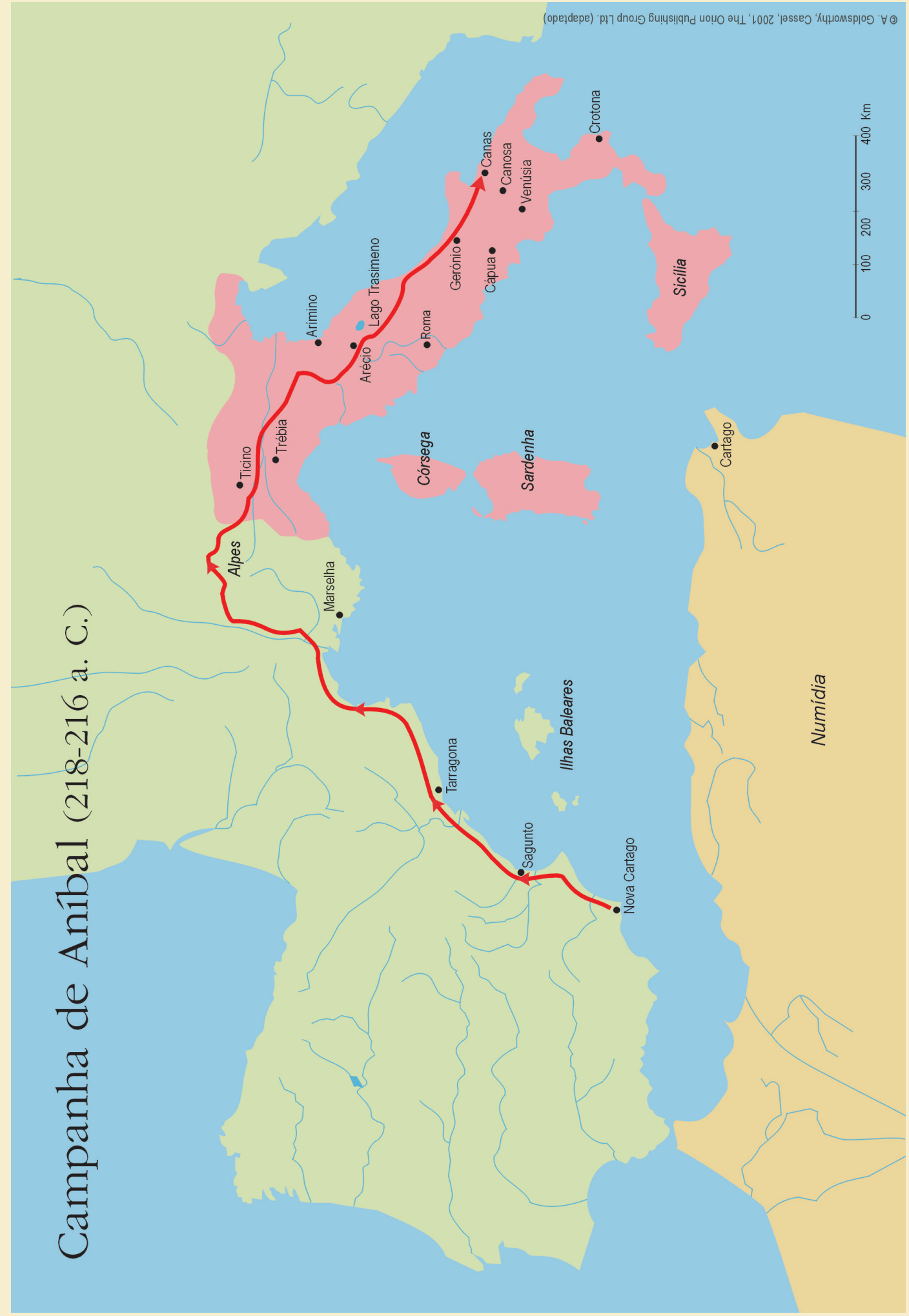


a notícia com estupefação, Cipião entregou o comando da maioria das suas tropas ao irmão Gneu (que as conduziria depois, por via marítima, até à Hispânia), enquanto regressou ele próprio a Itália para assumir o comando das tropas do vale do Pó, então em luta contra os Gauleses. Ao mesmo tempo, o Senado chamou Semprónio Longo, dando-lhe ordens para deixar a Sicília e vir juntar as suas forças às do outro cônsul na Gália Cisalpina (ou seja, na parte da Gália que ficava aquém dos Alpes, na perspetiva italiana).

\section{As batalhas do Rio Ticino, de Trébia e do Lago Trasimeno}

A operação romana, demasiado tardia, demorou algum tempo e isso permitiu a Aníbal, no início da sua progressão para sul através do território italiano, enfrentar as forças de Cipião antes de estas terem sido reforçadas pelas do outro cônsul. Foi junto ao rio Ticino e o combate (de cavalaria) traduziu-se numa primeira vitória cartaginesa, com a cavalaria italo-gálica de Cipião a ser cercada e desbaratada, ao ponto de o cônsul só ter escapado com vida graças ao socorro in extremis do seu próprio filho, o jovem Públio Cipião. Estava-se ainda em novembro de 218 a. C. e logo os Romanos trataram de rumar para Piacenza (Placência), onde escassas semanas depois se lhes juntou o cônsul Semprónio Longo.

O ano, porém, não haveria de terminar sem um novo combate, e desta feita já com as tropas dos dois cônsules romanos reunidas. A 22 de dezembro de 218 a. C., Romanos e Cartagineses bateram-se junto ao rio Trébia, nas proximidades de Piacenza. Por esta altura, já Aníbal tinha conseguido aumentar os seus efetivos para 28000 peões e 10000 cavaleiros, o suficiente para enfrentar em condições de relativa igualdade os $36000 \mathrm{a}$ 38000 peões romanos, apoiados por apenas 4000 cavaleiros. Nesta batalha, Aníbal escolheu o terreno e tratou de esconder 2000 homens numa vala de drenagem, sob o comando do seu irmão Magão Barca; os dois flancos do exército púnico foram preenchidos com uma cavalaria poderosa e muito moralizada pelo sucesso no rio Ticino, enquanto os flancos da infantaria se viram reforçados com 32 elefantes. O combate iniciou-se e a infantaria legionária (c. 10000 homens, ou seja, o equivalente a duas legiões), que 
povoava o centro romano, até foi bem-sucedida. Contudo, a cavalaria consular, largamente inferior em número à sua congénere púnica, foi arrasada, o que permitiu libertar a cavalaria cartaginesa das alas para uma manobra de envolvimento do exército romano que se revelaria decisiva. Grande parte dos legionários conseguiu retirar em boa ordem (uma vez que Aníbal não dispunha de uma reserva para os perseguir), mas a restante tropa romana foi presa, morta ou dispersou à toa. Claro que a notícia da derrota do exército dos dois cônsules constituiu um grande choque para o Senado romano: os Cartagineses prosseguiam a sua marcha para sul de forma imparável e atraíam cada vez mais Gauleses para o seu exército, reforçando-o, não apenas com efetivos, mas também com mantimentos.

Passado o inverno, em que não havia condições para o recomeço da luta, Aníbal preparou-se para atravessar os Apeninos. O Senado mandou então os dois novos cônsules (a eleição era anual) controlar os dois possíveis itinerários cartagineses: Gneu Servílio Gémino foi colocado em Arímino (atual Rimini), prevendo uma marcha costeira do general cartaginês, enquanto Gaio Flamínio se posicionou a ocidente, na Etrúria, junto às montanhas de Arécio. De nada valeu a precaução romana, pois Aníbal acelerou o passo, optou por uma estrada imprevista (através de terrenos pantanosos na região da Toscana, em torno do rio Arno, havendo quem defenda que nesta operação o general terá perdido um olho) e, de repente, quando os cônsules se aperceberam, já ele estava mais a sul... Restava a Flamínio, o cônsul que se encontrava mais perto, encetar uma perseguição a que Gémino deveria mais tarde associar-se.

Sabendo dessa marcha, Aníbal teve um novo golpe de génio. Nas margens do lago Trasimeno, e já com os Romanos à vista, aproveitou a noite e o nevoeiro para voltar para trás e emboscar Flamínio junto à estrada principal. O ataque deu-se a 21 de junho de 217 a. C. e teve como consequência o massacre do exército consular (25 000 a 30000 homens) e a morte do próprio Flamínio. A cavalaria avançada de Gémino (c. 4000 cavaleiros) apareceu pouco depois, mas, antes de ter tempo de se inteirar do desastre, foi ela própria chacinada. Aníbal (embora à custa de baixas não despiciendas: 1500 a 2500 homens) tinha superado mais um teste difícil. 
Fábio Máximo, o ditador "protelador"

Para grandes males, grandes remédios, e o Senado tratou então de nomear um ditador por um período de seis meses. O escolhido foi Quinto Fábio Máximo, homem de grande experiência (tinha quase 60 anos), pois combatera na Primeira Guerra Púnica e havia sido eleito cônsul duas vezes na sua carreira (o que não era vulgar). Para o auxiliar, na qualidade de "mestre da cavalaria" (magister equitum), foi nomeado Marco Minúcio Rufo, também ele um antigo cônsul. Esta dupla conseguiu em poucas semanas o feito de recrutar e organizar um novo exército romano, absorvendo os restos da hoste de Gémino e acrescentando-lhe novas unidades recém-mobilizadas. Num ápice, Fábio e Rufo passaram a dispor de quatro legiões (cerca de 20000 homens) e outras tantas tropas auxiliares. Era, porém, um exército muito desigual, fraco em cavalaria (devido à chacina da tropa avançada de Gémino no lago Trasimeno) e ainda com muito pouco treino de conjunto. Por isso, a estratégia de Fábio, inspirada na cultura militar helenística, revelar-se-ia muito prudente: perseguir o adversário, perturbar-lhe os movimentos, flagelá-lo o mais possível em pequenos combates parciais, dificultar o seu abastecimento, mas, ao mesmo tempo, evitar defrontá-lo em batalha, salvo se surgisse uma oportunidade excecional. Esta estratégia causava alguma impaciência em Roma (que ansiava por uma boa desforra), o que valeu a Fábio ser alcunhado de Cunctator (o "hesitante", ou "protelador").

Aníbal reagiu bem à pressão. Prosseguiu a sua marcha para sul através da planície costeira de Piceno (banhada pelo Adriático), proporcionou algum descanso aos seus homens (pela primeira vez desde a 'longa marcha'), trocou mensagens com Cartago solicitando reforços e foi observando cuidadosamente os movimentos dos Romanos. No entanto, nunca se coibiu de se deslocar por onde mais lhe convinha, devastando terras e bens à sua passagem, um facto que humilhava o adversário.

A determinada altura, em plena planície da Campânia, junto ao ager Falernus, Aníbal viu-se emboscado por Fábio Máximo nas vésperas de cruzar uma passagem estreita. A posição era forte e Aníbal não tinha comunicação com os seus aliados na Gália Cisalpina. Os exércitos estavam a meros $3 \mathrm{~km}$ 
de distância. Seria a oportunidade que Fábio aguardava? Tito Lívio diz que Aníbal tentou um ataque direto que foi repelido, mas Políbio (o grande historiador grego, mais fiável) nada diz sobre isso. Certo é que Aníbal acabou por se sair bem da situação, através de um estratagema genial: um certo Asdrúbal (responsável pelo abastecimento) reuniu muita madeira seca e mandou depois atar os gravetos aos cornos de 2000 bois capturados. À noite, os servos acenderam as tochas e conduziram o gado para a passagem, com o apoio da infantaria ligeira, ao mesmo tempo que o grosso do exército cartaginês formava em coluna de marcha com a melhor infantaria (a líbia) à frente. Os Romanos pensaram que as tochas indicavam a presença da coluna principal e desceram a encosta para atacar. A escaramuça confusa desfez-se quando as cabeças de gado, em pânico, irromperam pelo meio dela. Na barafunda, a passagem ficou temporariamente desimpedida e o exército cartaginês aproveitou para a atravessar sem oposição. Fábio ficou à espera até ao amanhecer, para ver se percebia o que estava a suceder (receava sofrer uma emboscada e no mundo antigo era raro combater-se de noite, devido à dificuldade em controlar as tropas). Ao nascer do sol, já o exército de Aníbal tinha atravessado, inclusive a infantaria ligeira que acompanhara a manada... Perto de 1000 Romanos foram mortos na operação. A grande capacidade de comando de Aníbal tinha acabado de causar uma profunda humilhação a Fábio e a Rufo, neste final de verão de 217 a. C.

O episódio amargurou o Senado, que chegou mesmo (caso inédito) a equiparar os poderes de Rufo (mais audacioso) aos de Fábio. Porém, Rufo foi mal sucedido logo nas suas duas primeiras intervenções (numa delas acabou por ser salvo pelo próprio Fábio) e o sistema voltou ao figurino anterior, com o ditador sempre no comando. No final do outono de 217 a. C., esgotados os seus mandatos, Fábio Máximo e Minúcio Rufo regressaram a Roma. Nessa altura, já Aníbal estava com o seu exército em Gerónio (na Apúlia), num aquartelamento de inverno relativamente próximo de Canas. O exército romano foi entregue a Servílio Gémino e a Marco Atílio Régulo (que substituíra Flamínio como cônsul). Fábio não conseguira travar Aníbal, mas também não sofrera grandes derrotas e, entretanto, tinha dado experiência aos novos soldados romanos, cujo recrutamento ele próprio providenciara. 


\section{O exército púnico}

Roma dedicou grande parte do inverno de 217-216 a. C. a preparar minuciosamente a campanha da primavera e verão de 216, que esperava pudesse conduzir ao aniquilamento de Aníbal. Desta vez, os dois cônsules eleitos (Lúcio Emílio Paulo e Gaio Terêncio Varrão) deveriam partir juntos desde o início, comandando alternadamente o maior exército que Roma reunira até então. Paulo (cônsul já uma vez, em 219 a. C.) tinha a experiência da guerra na Ilíria, em que fora bem-sucedido, enquanto Varrão (apesar de oriundo de uma família ainda sem pedigree na política romana) tinha já um cursus honorum interessante, pois fora questor em 222 a. C., edil em 221 e pretor em 218. No entanto, parece claro que nem um nem outro estavam preparados para enfrentar um exército tão profissional e experiente quanto o de Aníbal Barca.

Ao contrário dos romanos, os exércitos púnicos desta época já não eram compostos por cidadãos, mas sim por tropas contratadas. Por isso, eram forças multinacionais e bastante heterogéneas, oriundas de África e da Hispânia, mas também das Ilhas Baleares, da Gália, da Ligúria, da Grécia e de outros lugares. No entanto, o comando era sempre cartaginês, o que garantia uma certa unidade e bastante coerência de procedimentos, até porque, diferentemente de Roma, os generais de Cartago serviam durante muitos anos consecutivos e dispunham de grande autonomia. Ainda que fossem escolhidos por razões mais de natureza socioeconómica do que militar, adquiriam assim uma grande experiência e maturidade.

Segundo uma preciosa inscrição gravada numa coluna mandada erguer por Aníbal em Itália, as tropas púnicas que alcançaram o Norte de Itália depois de atravessarem os Alpes eram compostas pelos seguintes grupos: muita infantaria líbia (bastante forte e organizada, a nata do exército); cavalaria númida (experiente e muito ágil); valiosa cavalaria e infantaria (ligeira e pesada) hispânicas; muitos fundibulários das Ilhas Baleares (grandes especialistas no arremesso de pedras com funda); e uma pequena manada de elefantes (que todavia acabaria por morrer ainda antes da batalha de Canas). Depois, já em Itália, este exército foi engrossado com muitos contingentes de aliados gauleses, que viriam a constituir quase metade do exército de 
campo de Aníbal. Com forte componente tribal, o armamento era bastante heterogéneo, mas convém frisar que foi sendo melhorado graças ao imenso espólio capturado aos soldados romanos que tombaram no rio Ticino, em Trébia e no lago Trasimeno.

Sob o comando experiente e inspirador de Aníbal, pode bem dizer-se que se tratava do melhor exército da história de Cartago. Uma boa parte dos homens tinha bastante treino militar e adquirira muita experiência em anos consecutivos de serviço sob a liderança dos Barca, o que assegurava uma flexibilidade e uma capacidade de manobra invulgares. Além disso, tratava-se de um exército muito equilibrado, pois apresentava uma proporção de um cavaleiro para cada quatro peões, enquanto o exército romano de 216 a. C. não ia além de um homem montado para cada 13 soldados de infantaria. Por fim, o exército púnico que combateu em Canas (estima-se que composto por cerca de 40000 peões e 10000 cavaleiros) estava fortemente motivado por uma sucessão de êxitos estrondosos. E isto, em matéria militar, não é de somenos importância...

\section{A caminho da batalha}

Tudo indica que, pela primeira vez na sua história, Roma decidiu atribuir quatro legiões (e não duas) a cada um dos cônsules eleitos em 216 a. C. O Senado sabia que a tarefa era difícil e não queria falhar. É igualmente provável que cada uma das legiões, para além dos 300 cavaleiros do costume, tenha sido reforçada até aos 5000 infantes (mais 800 do que o habitual), para garantir um maior poderio. Como mandava a boa prática romana, os 40000 legionários de infantaria correspondentes a estas oito legiões eram acompanhados por igual número de peões das tropas aliadas (as chamadas "alas"), enquanto os 2400 cavaleiros das oito legiões eram completados com um número superior de cavalaria aliada (geralmente o triplo, mas em Canas, devido às derrotas recentemente averbadas, provavelmente não ultrapassaram os 3600). Ao todo, portanto, cerca de 80000 peões (valor indicativo máximo) e 6000 cavaleiros compunham o exército de Varrão e de Paulo que combateu em Canas. 
De onde provinha este exército? Metade provinha das legiões confiadas em 217 a. C. a Gémino (os sobreviventes de Trébia) e do recrutamento de emergência operado por Fábio Máximo e Minúcio Rufo. Estas seriam, à partida, as melhores tropas romanas, já com alguma experiência (embora diminuta) e prática de combate em conjunto. As restantes quatro legiões terão sido recrutadas em finais de 217 ou em inícios de 216 a. C., com vista à campanha decisiva. Estas últimas tropas teriam decerto muita vontade de vencer, mas o seu treino marcial e o seu grau de organização interna eram escassos. Também por isso, Roma apostou num enquadramento rigoroso, com tribunos militares experientes (incluindo Rufo) e o envolvimento pessoal de entre um quarto e um terço dos senadores! Todavia, ninguém tinha jamais comandado um exército que era, simplesmente, quatro vezes superior ao habitual. Além disso, a tradição de, quando os cônsules se juntavam, alternarem diariamente o comando do exército também não beneficiava a coerência e a eficácia das operações.

Seja como for, e embora se discuta ainda hoje - partindo das narrativas de Tito Lívio, de Políbio, de Plutarco e de Apiano - o posicionamento estratégico de Paulo (porventura mais prudente) e de Varrão (alegadamente mais ousado) perante a campanha de 216 a. C., parece certo que os dois cônsules iam decididos a enfrentar Aníbal em batalha campal, tal como o povo romano exigia (o Senado aprovara mesmo uma resolução nesse sentido); para isso, seguiram na sua peugada até à região da Apúlia. O exército cartaginês, sob a observação de Gémino e de Régulo (a quem o Senado tinha ordenado que aguardassem a chegada do grande exército consular), tinha-se movido junto à costa e alcançara Canas (c. 100 km a sul de Gerónio), onde se apropriou de um imenso depósito de provisões agrícolas recolhidas pelos Romanos. Em Canas, Aníbal decidiu aguardar a chegada dos adversários. O seu plano passava por fazer cada vez mais aliados em Itália (não estava a ser bem-sucedido neste particular, exceto com as tribos gálicas do vale do Pó), e isso implicava vencer de novo os Romanos em batalha campal. Portanto, sentimos que os dois exércitos estavam disponíveis para a batalha decisiva.

A sul de Gerónio, nas proximidades de Arpos, os dois cônsules juntaram-se ao restante exército romano. Nessa altura, Régulo terá solicitado escusa pela idade e regressou a Roma; quanto a Gémino, continuou incorporado, 
na condição de procônsul. Tudo isto terá acontecido cerca de uma semana antes do dia da batalha (2 de agosto de 216 a. C.). Ao segundo dia de marcha conjunta para sul através da planície litoral de Foggia, a hoste romana, numa coluna imensa que levantava uma tremenda poeira, deve ter entrado no campo de visão de Aníbal Barca, que ocupava um posto alto em Canas, com excelente panorâmica. O último troço da marcha dos Romanos fez-se já através de terreno aberto, a norte do rio Áufido (Ofanto). Obviamente, os Romanos procediam a reconhecimentos cuidadosos dos seus itinerários para evitar emboscadas como a que surpreendera Flamínio.

Estava-se então a 28 de julho, já nas imediações de Canas (lugar protegido a sul por uma linha montanhosa mas bastante aberto e plano a norte, com muita área cultivada e sem árvores), e era altura de se traçar o plano decisivo. Segundo Políbio, o cônsul Emílio Paulo ter-se-á mostrado favorável à procura de um terreno alternativo, mais montanhoso, para contrariar a superioridade da cavalaria púnica. Mas Varrão, talvez devido à dificuldade em movimentar um exército tão gigantesco e de o abastecer até que os Cartagineses aderissem à ideia de combater em terreno acidentado, terá preferido a possibilidade de uma batalha quase imediata. Neste sentido, a 29 de julho, dia em que detinha ele o comando, Varrão avançou na direção do acampamento adversário. Ao que parece, a operação causou alguma confusão e desencadeou escaramuças menores, envolvendo a infantaria ligeira dos velites e alguma cavalaria. No dia seguinte, Paulo ordenou que o exército avançasse mais um pouco, com isso parecendo render-se à ideia de travar batalha, tanto mais que a proximidade do inimigo já não permitiria pensar em recuos seguros.

Em conformidade, a 30 de julho o exército romano acampou dois terços da sua hoste na margem norte do rio Ofanto (bem separado do adversário, que continuava no terreno elevado de Canas, do outro lado do rio). A restante tropa atravessou o curso de água e assentou arraiais a pouco mais de $1,5 \mathrm{~km}$ a sul (isto é, na mesma margem dos Cartagineses mas ainda assim bastante afastada deles). A ideia dos cônsules seria, decerto, encarar o adversário e desafiá-lo através da instalação de acampamentos claramente ofensivos, que permitiam também controlar as áreas envolventes e as inevitáveis operações de forragem dos Cartagineses. 
A isto respondeu Aníbal de forma muito simples: fez um discurso de exortação às suas tropas e transferiu o acampamento púnico para a outra margem do Ofanto (onde estava o corpo principal do exército romano), ocupando sempre um ponto alto e com água por perto. Não era menor a disponibilidade dos Cartagineses para lutar e, por isso, ocuparam grande parte do dia $31 \mathrm{com}$ descanso e com a limpeza das armas. No dia seguinte (1 de agosto), Aníbal dispôs o seu exército em linha de batalha na margem esquerda do rio, bem de frente para o principal acampamento romano. Mas Paulo, que comandava nesse dia, recusou arriscar e limitou-se a colocar forças de cobertura diante de cada um dos arraiais romanos. Ao fim de umas horas de espera, Aníbal retirou as suas tropas, decerto satisfeito com o impacto psicológico desta demonstração de força e de confiança. Entretanto, a cavalaria númida foi enviada num raide relâmpago através do rio Ofanto, atacando o pequeno acampamento romano, lançando o pânico, desmoralizando as tropas e mostrando a inutilidade desta posição adversária.

\section{O dispositivo tático romano}

No dia 2 de agosto, compreendendo que a situação era insustentável, Varrão decidiu enfim travar batalha. Ao amanhecer, formou os seus homens dentro do acampamento principal, liderando depois a extensa coluna que atravessou o rio num vau propício. Na margem direita, juntaram-se-lhe as tropas do acampamento pequeno, posto o que se dispuseram todas em formação de combate.

Não é absolutamente segura a localização exata do campo de batalha, tanto mais que o curso do rio Ofanto parece ter-se alterado desde a data do combate, o que naturalmente complica (e muito) as reconstituições modernas. Parece, no entanto, claro que o exército romano dispôs as suas tropas viradas para sudoeste, num terreno plano com um máximo de dois quilómetros de extensão, estando o flanco esquerdo protegido pelos montes que rodeiam a povoação de Canas e o flanco direito apoiado na margem sul do rio Ofanto (que na época correria um pouco mais a norte do que acontece hoje). A ideia era certamente evitar os envolvimentos pela pode- 
rosa cavalaria púnica e apostar o mais possível no combate a travar na zona central do terreno, onde a infantaria legionária tinha muitas possibilidades de ser bem-sucedida.

Temos informação de que 10000 homens (possivelmente uma legião e uma "ala" completas) ficaram a guardar o acampamento principal, enquanto outros 3000 (porventura não combatentes, apenas semiarmados dada a posição algo recuada deste arraial) permaneceram no acampamento mais pequeno. Como de costume, a infantaria pesada (sete legiões e o equivalente em "alas") ocupou o centro da posição romana, enquanto a cavalaria foi disposta nos flancos: à direita, os 2400 homens da cavalaria romana, sob o comando de Paulo; à esquerda, os 3600 cavaleiros aliados, sob a chefia de Varrão. Podemos admitir que os dois corpos de cavalaria estivessem organizados em 10 filas, com uma profundidade total de uns 40 metros. No entanto, devido ao seu maior número, a cavalaria aliada devia ocupar uma frente de perto de $540 \mathrm{~m}$, contra $360 \mathrm{~m}$ da sua congénere romana posicionada no flanco direito, junto ao rio. Aparentemente, pedia-se a estes corpos de cavalaria que aguentassem o melhor possível e durante o máximo de tempo o ataque da poderosa cavalaria púnica. Não era tarefa fácil, devido à desproporção numérica, mas era essencial que isso acontecesse para dar tempo ao centro da linha romana (comandado por Gémino) de consumar a vitória nessa zona nuclear do terreno. Não foi por acaso que os dois cônsules tomaram a seu cargo as forças de cavalaria, a quem estaria destinada a tarefa mais ingrata: perder, sim, mas devagar...

Quanto às sete legiões e respetivas "alas”, foram certamente dispostas nas três linhas (triplex acies) do costume: os hastati (jovens com cerca de 20 anos de idade) na frente; os principes (homens já maduros, perto dos 30 anos) no meio; e os triarii (os mais velhos e experientes, em número equivalente a metade de cada uma das outras duas linhas) atrás. De fora deste alinhamento, prontos para as escaramuças iniciais, ficaram os velites (a infantaria ligeira romana, recrutada entre os cidadãos mais pobres e os demasiado jovens para poderem servir com os hastati). Contas feitas, e a título indicativo, é possível que Gémino tivesse sob a sua tutela, em cada legião ou "ala", uma primeira linha (hastati) com 1466 homens, uma segunda (principes) equivalente, e uma terceira linha com cerca de 600 triarii, 
isto para além de 1466 velites. No total, os tais c. 5000 homens por legião ou "ala". Tratando-se de sete legiões e outras tantas "alas", podemos imaginar cerca de 70000 homens assim distribuídos naquela pequena planície entre o rio e a montanha: 20524 hastati, 20524 principes e 8400 triarii, para além de, no máximo (já talvez um pouco inflacionado), 20524 velites.

Os homens das duas primeiras linhas da infantaria pesada (hastati e principes) usavam, como equipamento defensivo, um capacete de bronze, um peitoral de bronze ou de ferro (ou, no caso dos mais ricos, uma cota de malha composta por anéis metálicos entrelaçados ou por pequenas placas de metal fixadas numa base de tecido ou de couro, à maneira de escamas) e um escudo oval com cerca de 1,20 m de comprimento por metade de largura e até $10 \mathrm{~kg}$ de peso. Muitos usariam também uma greva (caneleira) na perna esquerda, mais exposta em virtude de estar geralmente mais adiantada. Como armas ofensivas, hastati e principes utilizavam sobretudo uma espada curta de origem hispânica chamada gládio (com 50 a 60 cm de comprimento), que era uma arma de estoque terrível, com uma longa ponta afiada, mas que também podia ser usada para corte lateral, pois tinha uma lâmina robusta com um duplo gume muito afiado. O gládio era utilizado do lado direito (salvo no caso dos centuriões e porta-estandartes), com a bainha suspensa por quatro anéis a um cinturão; assim, quando sacava o gládio, o legionário não precisava de mover o escudo que segurava na mão esquerda, evitando expor o flanco ao inimigo. Além do gládio, os legionários das duas primeiras linhas dispunham também de um punhal com lâmina de folha larga e ponta afilada (com não mais de $35 \mathrm{~cm}$ de comprimento, embainhado do lado esquerdo) e dois dardos de arremesso (o pilum) com um comprimento total de cerca de 2 metros. O pilum era composto por uma longa haste de ferro (com 60 a $90 \mathrm{~cm}$, munida de uma pequena cabeça em formato piramidal) ligada a um cabo de madeira, sendo o encabamento facilitado por uma espécie de bolbo esférico ou piramidal; bem arremessado (sobretudo de cima para baixo e a curta distância: menos de $15 \mathrm{~m}$ ), podia trespassar peões munidos de escudo ou cavaleiros com loriga; tinha também a vantagem de ser muito difícil de desencravar (uma vez que encurvava depois do impacto), podendo por isso obrigar os adversários a abandonar os seus próprios escudos e a prosseguir a luta sem a sua principal proteção de corpo! 


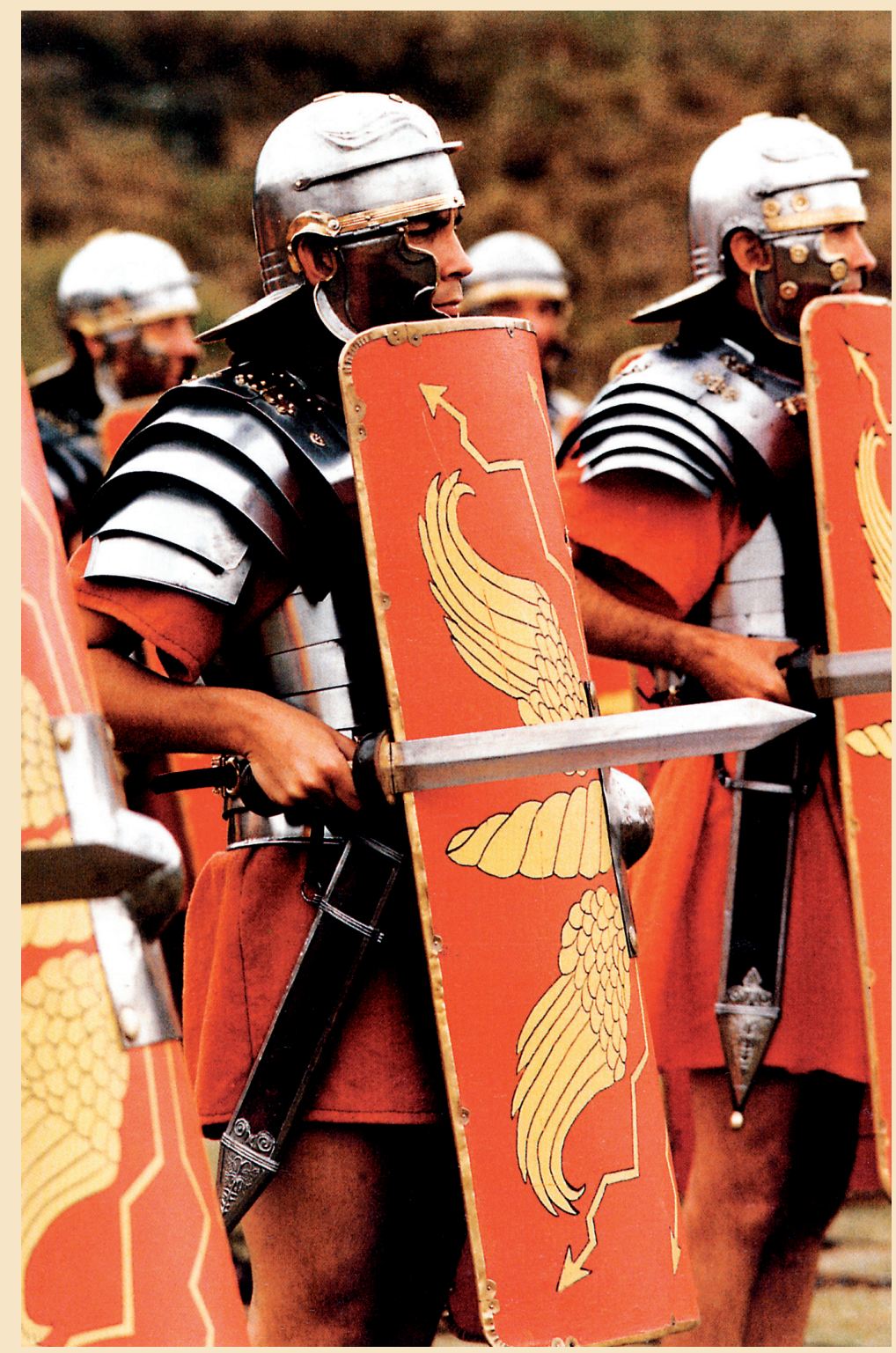

Legionário romano de finais do séc. I d. C., em formação de combate, vestindo loriga articulada, empunhando o gládio na mão direita e segurando o escudo (nesta época já retangular) no braço esquerdo.

(C) D. Zienkiewicz, Museu Nacional de Gales, reconstituições pela Ermine Street Guard, 1994 


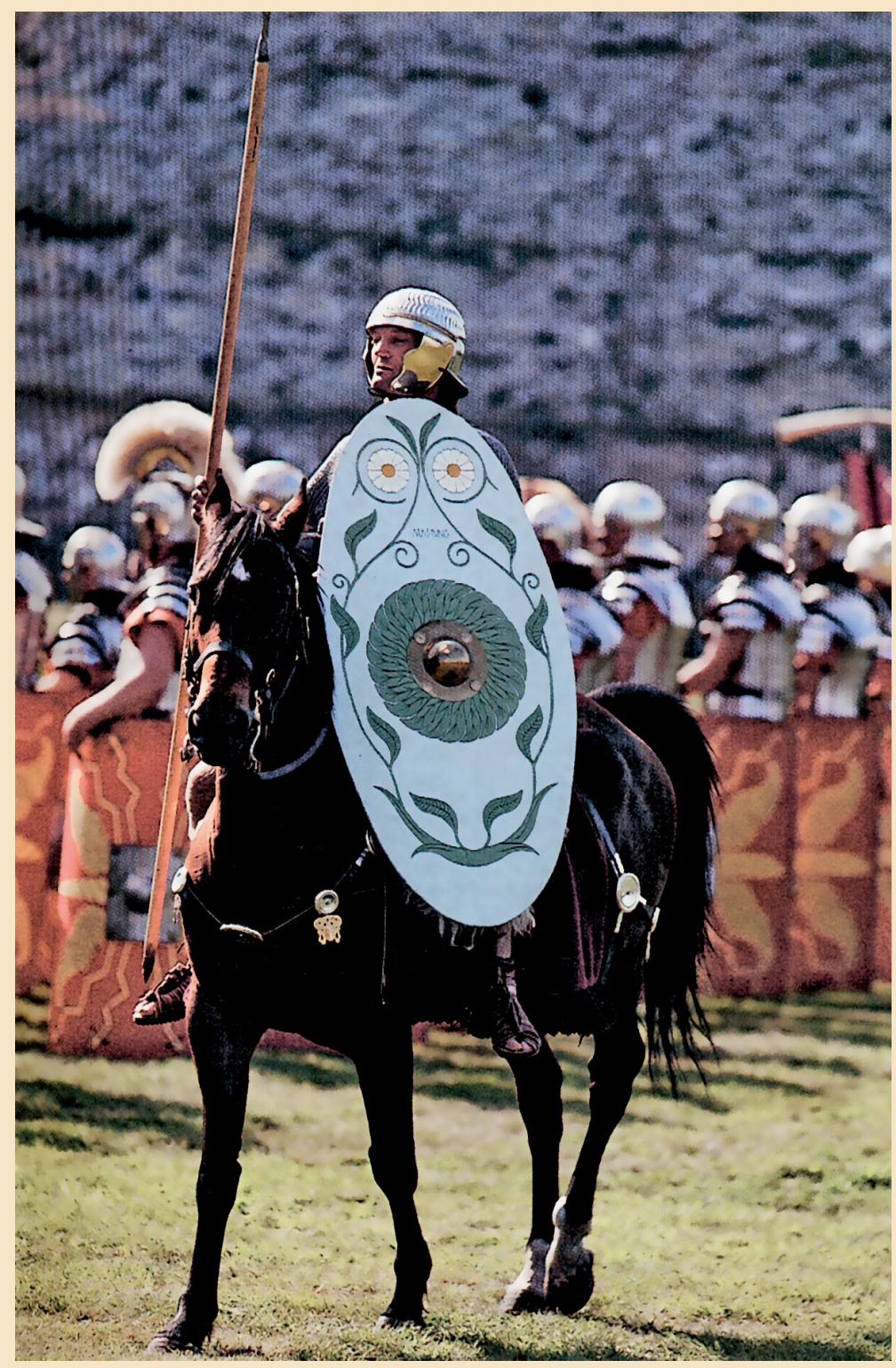

Cavaleiro auxiliar romano armado de lança e escudo oval.

Repare-se que os cavaleiros romanos ainda não dispunham de estribo (nem de sela alta com arções).

(C) D. Zienkiewicz, Museu Nacional de Gales, reconstituições pela Ermine Street Guard, 1994 
O equipamento defensivo dos triarii era semelhante ao dos hastati e dos principes, mas, devido à sua posição mais recuada, o seu armamento ofensivo distinguia-se por utilizarem sobretudo longas lanças de arremesso com cerca de $2 \mathrm{~m}$ de comprimento. Quanto aos velites (a infantaria ligeira utilizada sobretudo na abertura dos combates), dispunham de pequenos escudos redondos (menos peso significava maior mobilidade) e, por vezes, de capacetes; como armas ofensivas, recorriam principalmente à espada e a dardos. Muitos traziam peças de pele de animal (em especial de lobo) agarradas aos capacetes, para intimidarem os seus adversários e mais facilmente serem reconhecidos pelos seus oficiais.

Podemos perguntar se toda esta força cabia no local eleito por Varrão como campo de batalha. De acordo com o testemunho de Políbio, os Romanos usaram em Canas um dispositivo pouco comum, devido à dimensão invulgar do seu exército. O historiador grego, que aliás principia as suas narrativas com a descrição das Guerras Púnicas, explica que os manípulos romanos em Canas (isto é, as 10 unidades em que se decompunha cada linha da legião ou ala) tinham uma profundidade anormal. Adrian Goldsworthy (o grande especialista da batalha e que, por isso, aqui acompanhamos mais de perto) estimou para cada manípulo das legiões e "alas" das primeiras duas linhas cerca de 145 homens, arrumados em 29 filas, cada qual com uma frente de 5 homens (ou seja, cerca de $5 \mathrm{~m}$ de frente por $58 \mathrm{~m}$ de fundo). Devido às restrições de espaço (exército mais vasto e terreno relativamente estreito), os habituais intervalos entre dois manípulos (geralmente equivalentes à frente de cada uma destas unidades) foram reduzidos, talvez, a metade. Deste modo, os dez manípulos que formavam a primeira linha (hastati) de uma só legião ocupariam cerca de $75 \mathrm{~m}$ de frente por $58 \mathrm{~m}$ de profundidade; e toda a primeira linha romana (as sete legiões mais as sete "alas") cobriria perto de $1050 \mathrm{~m}$ de frente por $58 \mathrm{~m}$ de fundo. Na segunda linha, o mesmo sucederia com os principes, enquanto os triarii, por serem menos (600 em cada legião), poderiam apresentar uma formação mais equilibrada: talvez 5 homens de frente em 12 filas umas atrás das outras, por manípulo. Contas feitas, podemos admitir um centro romano em Canas com uma frente de pouco mais de $1 \mathrm{~km}$ de largura e uma profundidade de 140 a 160 metros (70 filas mais os inevitáveis espaçamentos entre as três linhas principais). 


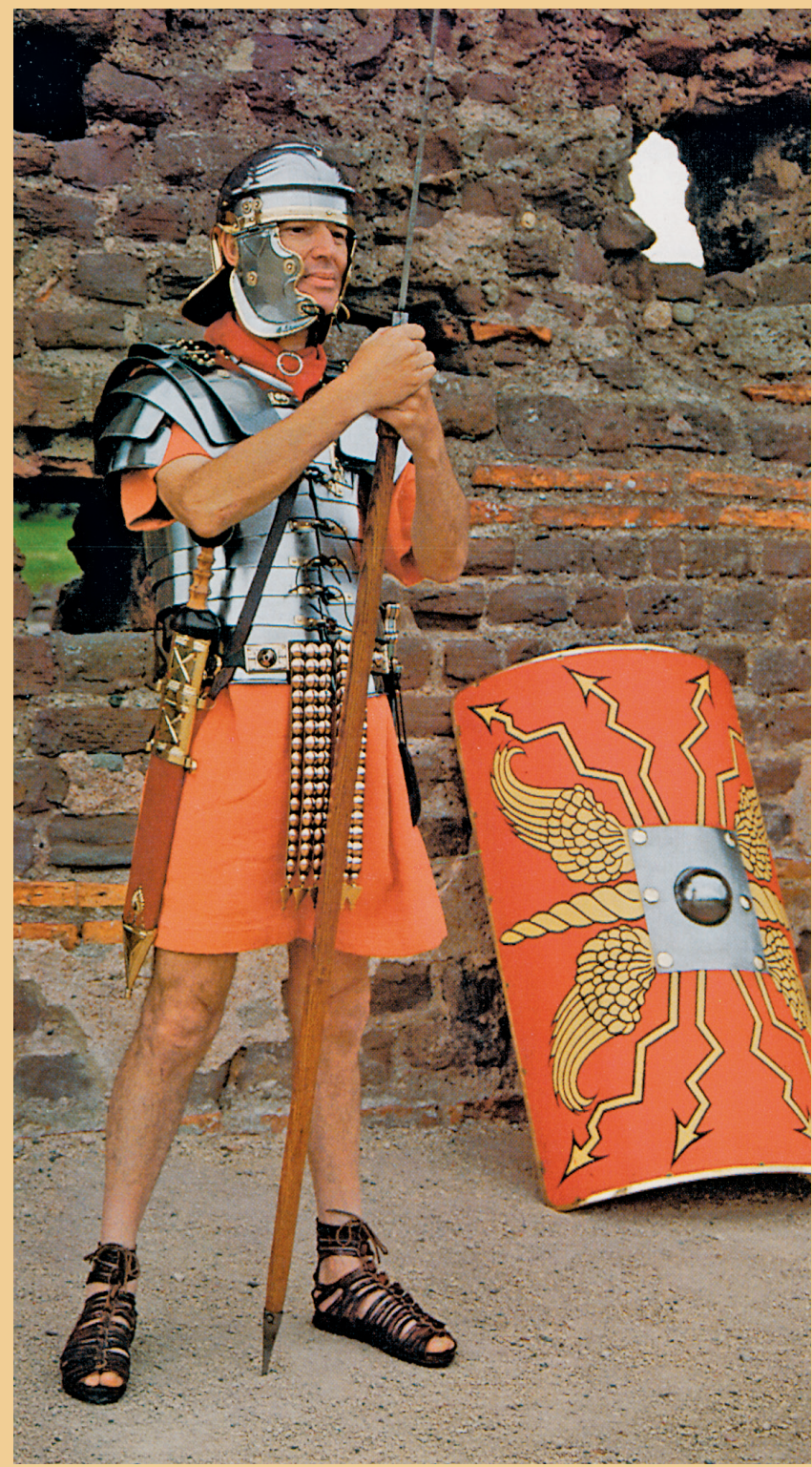

Legionário romano de finais do séc. I d. C., armado com gládio, pilum e punhal, e protegido por capacete com paragnátides, loriga articulada e escudo retangular com umbo (bossa) central. Repare-se também nas caligae, as famosas sandálias romanas, talhadas numa peça única de couro e atadas em cima, na canela.

(C) D. Zienkiewicz, Museu Nacional de Gales, reconstituições pela Ermine Street Guard, 1994 


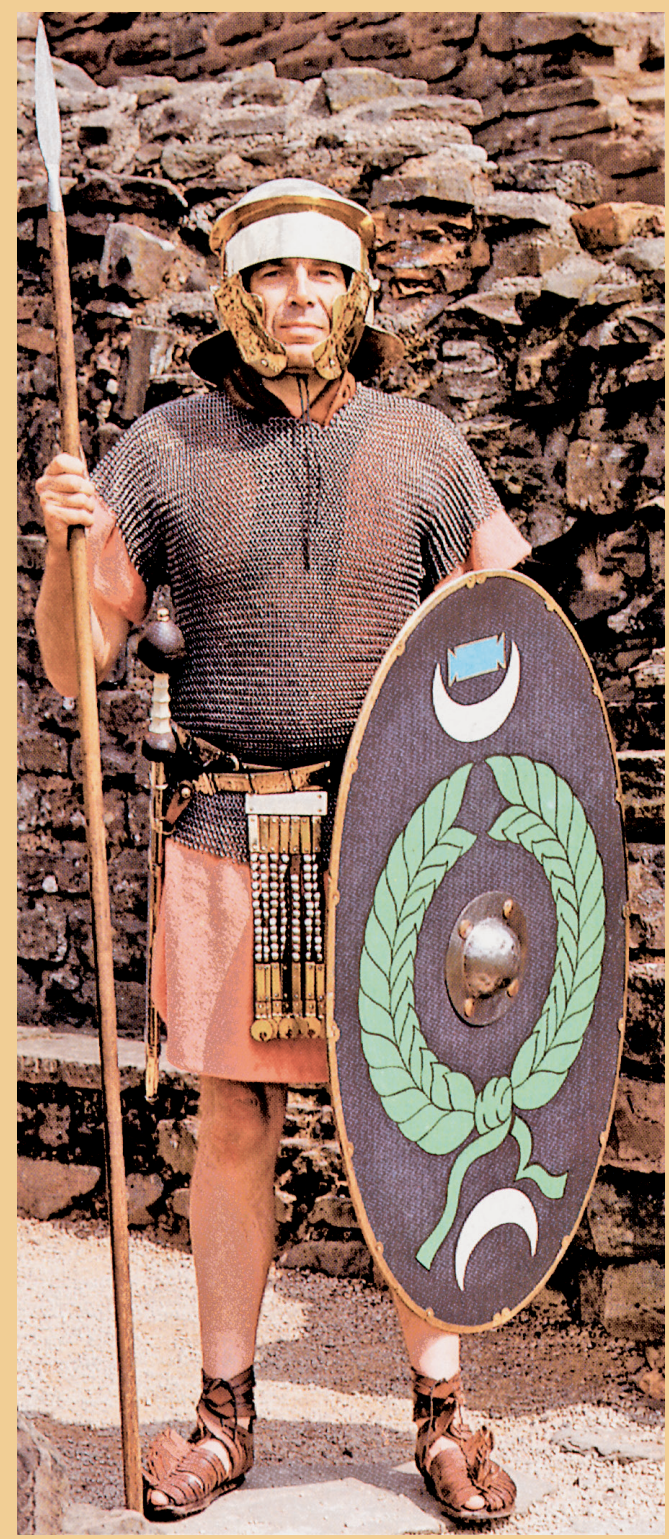

Soldado de infantaria auxiliar romana de finais do séc. I d. C., armado de lança e gládio (empunhado do lado direito), e protegido por capacete com paragnátides, loriga de malha metálica e escudo oval decorado, munido de bossa central metálica.

(C) D. Zienkiewicz, Museu Nacional de Gales, reconstituições pela Ermine Street Guard, 1994 
Ao todo, considerando também a cavalaria romana e aliada, colocadas nos flancos, o exército de Varrão e de Paulo ofereceria ao adversário, naquela tarde de agosto de 216 a. C., uma frente de muito perto de $2 \mathrm{~km}$ de extensão, ou seja, bem à medida do espaço disponível para o combate.

Esta situação trazia benefícios aos Romanos, que assim garantiam o não envolvimento dos flancos pela cavalaria adversária, a não ser quando os corpos comandados por Paulo e por Varrão finalmente cedessem, o que se desejava viesse a acontecer já numa fase muito tardia da batalha, logo sem consequências nefastas para os Romanos. Por outro lado, uma formação de frente mais estreita e profunda avança de maneira mais organizada, sem se deixar afetar tanto pelas irregularidades do terreno e sendo mais fácil de comandar. Por isso, parece mais adequada a um exército com pouco treino, tanto mais que os soldados se sentiam mais seguros e protegidos por estarem, na sua grande maioria, muito distantes da linha da frente. E, assim sendo, resistiam mais longamente e tinham menos tendência para fugir. Mas, por outro lado, este dispositivo tinha os seus inconvenientes: os manípulos, separados por intervalos invulgarmente pequenos, corriam o risco de encostar uns nos outros, transformando o centro numa única massa amalgamada, sem a flexibilidade tática indispensável para responder às diferentes solicitações geradas durante o combate e com pouca capacidade de manobra (pois a partir de certa altura podiam tornar-se impossíveis de comandar). Além disso, o armamento romano também não se adequava muito bem a este dispositivo: os legionários usavam o gládio (uma arma de estoque) e o pilum (eficaz a menos de $15 \mathrm{~m}$ ). Ora, numa frente estreita, a maioria dos soldados não podia golpear o adversário, enquanto o arremesso do pilum ficava restringido aos homens das primeiras sete ou oito filas...

Parece, portanto, que foi a inexperiência da maioria dos soldados romanos e o receio da cavalaria púnica que motivaram as escolhas de Varrão e de Paulo. Apostaram tudo na grande capacidade ofensiva das legiões, a quem competiria arrasar o centro da formação cartaginesa, no pressuposto de que, depois, a cavalaria púnica, sozinha, mesmo tendo acabado por vencer os combates nos flancos, não seria capaz de derrotar as sete legiões e as "alas" que as acompanhavam. O facto de ter sido Varrão a tomar a iniciativa do combate no dia 2 de agosto, e de ter por isso escolhido o terreno da refrega, também deve ter moralizado o exército romano. 


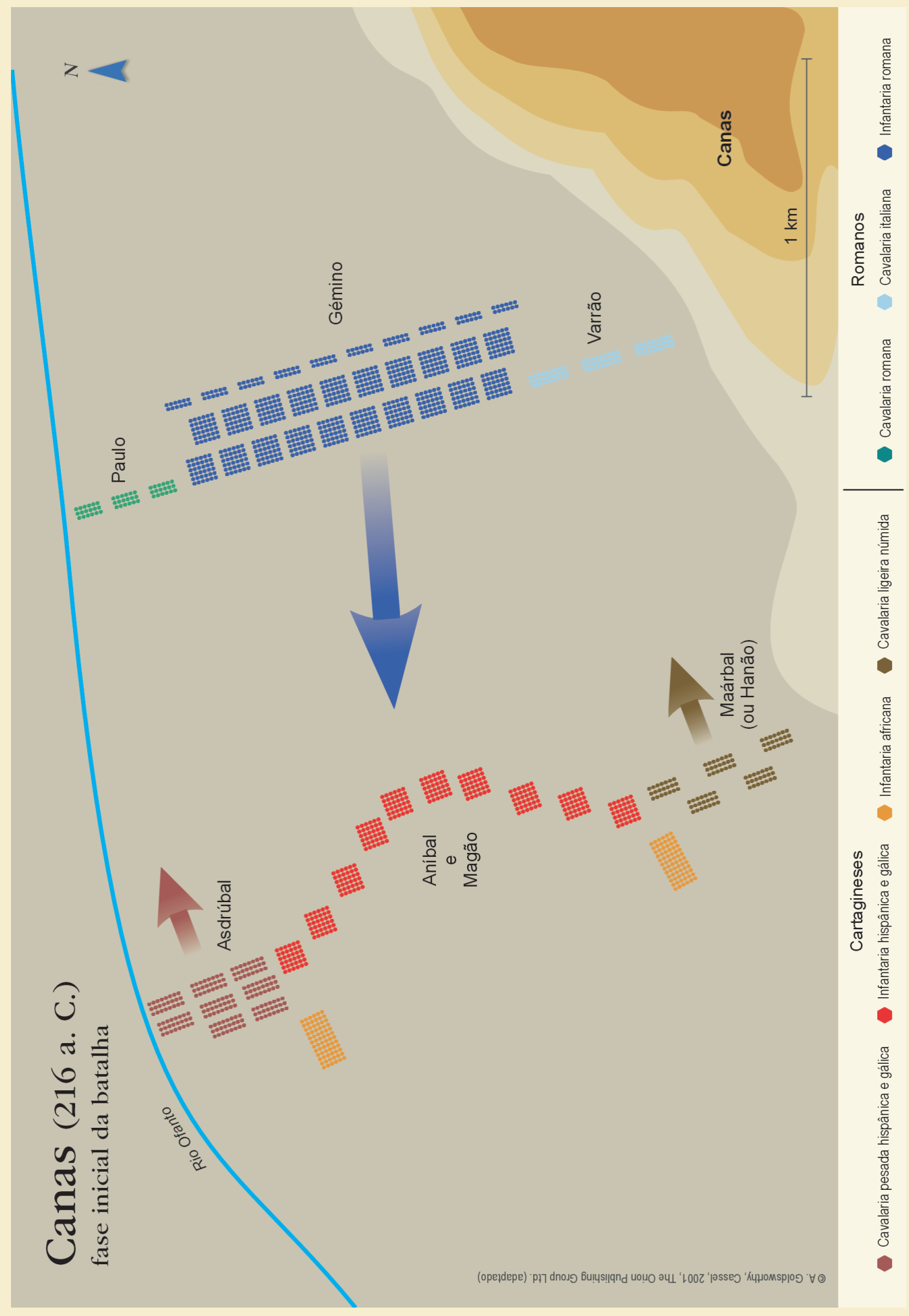




\section{A organização do exército púnico}

Vejamos agora como respondeu Aníbal e como dispôs ele os seus 10000 cavaleiros (6000 cavaleiros pesados hispânicos e gauleses mais 3000 a 4000 homens da cavalaria ligeira dos Númidas) e os seus perto de 40000 soldados de infantaria, dos quais 8000 escaramuceiros (infantaria ligeira) e 32000 soldados de infantaria pesada (8000 a 9000 Líbios, 3000 a 4000 Hispânicos e 19000 a 21000 Gauleses).

A cavalaria foi colocada nas alas: à esquerda, junto ao rio e de frente para o corpo comandado por Paulo, a tropa pesada (ou seja, os 6000 cavaleiros hispânicos e gauleses), sob o comando de Asdrúbal Barca (irmão de Aníbal); à direita, junto ao sopé da montanha de Canas e enfrentando diretamente os homens de Varrão, a cavalaria ligeira númida, liderada por Maárbal (segundo Tito Lívio) ou por Hanão (de acordo com Políbio). Com isto, Aníbal conseguia uma superioridade manifesta no seu flanco esquerdo (6000 contra 2400), enquanto a ala contrária ficava relativamente equilibrada (3 a 4 mil Númidas para 3600 cavaleiros itálicos ao serviço de Roma). Sabemos pouco acerca da forma como toda esta cavalaria estava organizada, mas é natural que variasse bastante: os cavaleiros pesados hispânicos e gauleses deviam estar repartidos por várias linhas de modo a não se misturarem demasiado e a serem mais facilmente controlados pelos respetivos oficiais; já a cavalaria ligeira númida gostava de combater de maneira mais livre, avançando e retirando sucessivamente e em pequenos grupos, bem à maneira do que viriam a fazer as tropas muçulmanas (árabes ou turcas) no período das Cruzadas.

Em matéria de armamento, a cavalaria hispânica utilizava espadas de grande qualidade, seja de dimensão curta (do tipo do gládio), seja de formato curvo (as falcatas); como vestuário, envergavam túnicas brancas com uma orla púrpura. Quanto à cavalaria pesada gaulesa, estava habituada a combater em massa e usava selas de quatro pontas (talvez de origem celta), tendo como principal proteção defensiva um escudo oval ou retangular (só os chefes dispunham de capacetes e de armaduras de corpo). Para atacar, recorria a uma grande variedade de lanças e de dardos de arremesso e, no caso dos mais ricos, a espadas bastante mais longas do que o gládio, com 
lâminas que podiam atingir cerca de $90 \mathrm{~cm}$ de comprimento, por vezes sem pontas, boas para cortar lateralmente, em golpes de pura força física. É possível que Aníbal tivesse também podido dispor de cavalaria líbia, ou líbio-fenícia; se assim foi, combatia em formação cerrada e com um equipamento que permitiria compará-la com a cavalaria romana. No que diz respeito à cavalaria ligeira númida, apresentava montadas pequenas e ágeis, sem sela nem rédea, e os cavaleiros envergavam apenas uma túnica e um escudo redondo de dimensões reduzidas, para além de lanças curtas, boas para arremessar.

Quanto à infantaria, em particular aos 32000 homens com equipamento mais pesado, Aníbal dispô-los de forma superior. Na zona central, no coração da batalha, colocou cerca de 24000 hispânicos (munidos de escudos planos com formato oval e, nalguns casos, de dardos de arremesso comparáveis ao pilum romano, para além de gládios e falcatas) e gauleses (armados muito à semelhança dos cavaleiros com a mesma origem: lanças, dardos e espadas de lâmina comprida). Esta era a massa guerreira que, sob o comando do próprio Aníbal e do seu irmão Magão Barca, iria, apesar do seu equipamento defensivo muito rudimentar, suportar o peso principal do combate (isto é, a investida das legiões). Em cada uma das zonas laterais do centro, mas em posição recuada e provavelmente sem possibilidade de ser avistado pelos Romanos, colocou um corpo de 4000 a 5000 soldados líbios. Esta tropa de elite, altamente disciplinada e treinada, munida de um equipamento de matriz helenística (capacetes de bronze e armadura de corpo à base de linho reforçado, largos escudos redondos e lanças) porventura completado com os despojos do equipamento romano capturado em Ticino, em Trébia e no lago Trasimeno, ficaria como que reservada para uma fase mais adiantada do combate e, de certo modo, seria ela a decidir a jornada. Ao mesmo tempo, Aníbal avançou as tropas intermédias da sua zona central, formando uma cunha apontada à infantaria legionária, o que fez com que o seu dispositivo tivesse adquirido a forma de um crescente que ainda hoje é objeto de estudo entre os especialistas. Com isto, Aníbal atraía o ataque romano para o veio central do terreno e deixava as alas de Paulo e de Varrão entregues a si próprias. 
Quanto à infantaria ligeira (os c. 8000 escaramuceiros), era extremamente variada, pois incluía dardeiros líbios, caetrati hispânicos (munidos de pequenos escudos redondos e de feixes de dardos para arremessar), os famosos fundibulários das Ilhas Baleares e, talvez, alguma peonagem gaulesa (a mais pobre, ou mais jovem, pois a tradição da guerra tribal conferia mais prestígio ao combate corpo a corpo). Não sendo numerosa, esta infantaria ligeira superava claramente, em eficiência e diversidade tática, a infantaria ligeira romana.

É difícil dizer se Aníbal pôde (ou não) conceber de véspera o seu plano, uma vez que teve de se adaptar à escolha do terreno feita pelos Romanos. Provavelmente, as decisões de colocar a cavalaria nos flancos e a infantaria líbia em posição recuada e quase camuflada nos extremos da zona central podem ter sido tomadas no dia anterior. Já a formação da cunha central pode ter sido confirmada só no dia da batalha perante a situação concreta dos dois exércitos no terreno, a menos que Aníbal tenha conseguido obter informação prévia acerca do plano de combate dos cônsules romanos.

\section{O combate}

As duas hostes devem ter levado horas até se disporem por completo no campo de batalha. O calor era intenso e a poeira levantada por mais de 130000 homens e cavalos movimentando-se numa área de quatro ou cinco quilómetros quadrados seria cerrada. Tanto mais que o famoso vento vulturno soprou nessa tarde fortes rajadas de sudeste, que parece terem incomodado muito os soldados romanos. Pouco se sabe sobre as escaramuças iniciais que opuseram os velites à infantaria ligeira ao serviço dos Barca (muito menos numerosa mas de maior qualidade). Lanças, dardos, fundas, possivelmente alguns arcos também, ocuparam nesta fase o palco principal, com as tropas de um lado e do outro a procurarem atingir o adversário, sem no entanto se aproximarem demasiado para não ficarem sujeitas a uma carga súbita da infantaria ou da cavalaria inimigas. Deste aperitivo não parece terem resultado muitas baixas, até porque esta infantaria ligeira se fazia geralmente acompanhar de escudos e, mais do que em matar um opositor, pensava sobretudo em regressar sem feridas graves à sua posição original. 
A certa altura, a infantaria ligeira púnica (escaramuceiros) retirou e foi apoiar a sua cavalaria. Entrou-se então na segunda fase da batalha, com um ataque em força da cavalaria pesada de Asdrúbal sobre o flanco direito romano, comandado por Emílio Paulo. A descrição das fontes aponta para um combate violentíssimo, e tanto Políbio como Tito Lívio (e também Apiano e até Plutarco) admitem que muitos combateram a pé. Algumas fontes relacionam esta hipótese com um ferimento que terá atingido o cônsul Paulo, obrigando-o a desmontar, mas é mais provável que na realidade houvesse alguns corpos de infantaria misturados com os cavaleiros, com o objetivo de dar uma maior solidez e estabilidade ao conjunto. Isso não era raro no mundo antigo e, tendo em conta os desaires sofridos pela cavalaria romana nos combates anteriores contra Aníbal, é uma hipótese que podemos admitir. Seja como for, parece certo que o plano romano para o combate nesta zona do terreno falhou rotundamente: adotando uma atitude demasiado estática, defensiva (já que o seu objetivo era apenas resistir), a cavalaria romana perdeu mobilidade e foi varrida depressa e em força pela cavalaria pesada hispânica e gaulesa, também muito superior em número. O flanco direito romano debandou e Asdrúbal marcava assim os primeiros pontos a favor de Aníbal e podia agora ir cumprir outras tarefas no campo de batalha. A Paulo, pelo seu lado, restou escapar com aqueles que pôde e encaminhar-se para a zona central do terreno, para juntar a sua voz à de Gémino.

Entretanto, no outro flanco, o combate estava mais renhido, também devido ao maior equilíbrio de forças envolvidas. A cavalaria itálica, chefiada por Varrão, ia aguentando os ataques da cavalaria ligeira númida, sem no entanto fazer grandes esforços para a repelir completamente.

Entramos assim na terceira fase da batalha, e a mais espetacular. No centro, a infantaria romana avançou em força sobre a cunha cartaginesa. O estrépito foi enorme, com gritos de guerra, soar de trombetas militares e provocações de parte a parte, sob um calor estival e um vento de poeira cerrada que certamente turvaria bastante a visão dos combatentes. Ambos os lados tinham razões para estar confiantes e ambos empenharam então o mais possível os seus melhores oficiais para que o controlo dos movimentos se fizesse de acordo com o plano traçado. As filas mais adiantadas da primeira linha romana (os hastati) devem ter arremessado os seus pila assim que o 
adversário ficou dentro do seu raio de ação; para tanto, a formação deve ter abrandado um pouco. Seguiu-se uma troca de mísseis a curta distância e com eficácia progressiva, provocando a primeira torrente de baixas nesta zona do campo. Para avançar sob tiro cerrado, os homens protegiam-se o melhor que podiam com os seus escudos e baixavam ligeiramente a cabeça. A maior parte dos ferimentos atingia por isso a parte baixa das pernas ou o rosto (de cada vez que era preciso armar o braço para um novo arremesso).

Em consequência do dispositivo muito profundo adotado pelas legiões, só os homens das primeiras filas podiam visar nitidamente os adversários. No meio e atrás, a tensão devia ser enorme, agravada pelo ruído e pela dúvida acerca dos resultados reais da investida. Ontem como hoje, só uma minoria dos homens lutava realmente para matar: uma parte dos soldados acabava por não entrar de facto no combate e a outra - a grande maioria travava-o de forma limitada, pensando mais em não ser ferida do que em aniquilar o inimigo. Não devemos imaginar a batalha a degenerar em múltiplos duelos individuais, em lutas corpo a corpo isoladas ao estilo cinematográfico, pois fora da sua formação cerrada os soldados tornar-se-iam ainda mais vulneráveis. Do mesmo modo, não devemos pensar que os homens das filas de trás tratavam de empurrar os camaradas da frente, um pouco à maneira das falanges clássicas, pois uma tal ação desequilibraria demasiado as linhas dianteiras num combate deste tipo, com armas curtas e próprias para perfurar ou cortar de través. Pelo contrário, sucediam-se os avanços e recuos das linhas, ou de parte delas, consoante a pressão adversária e a necessidade de retemperar as forças e os ânimos.

Um combate deste género tendia a prolongar-se bastante, contrariamente ao desejo dos Romanos, que aspiravam a uma vitória rápida no centro. Eram raros os golpes mortais, pois expunham demasiado os seus autores, e só a acumulação de 'pequenas' feridas ou a exaustão devida ao esforço físico e ao calor levavam uma formação a ceder gradualmente terreno. Foi o que sucedeu com a infantaria pesada cartaginesa, que aos poucos começou a recuar, porventura convidando o adversário a penetrar, um pouco à maneira da "manobra envolvente" helenística (convém não esquecer que Amílcar Barca contratara como conselheiro, durante a Primeira Guerra Púnica, o mercenário grego Xantipo, bom conhecedor das táticas militares 


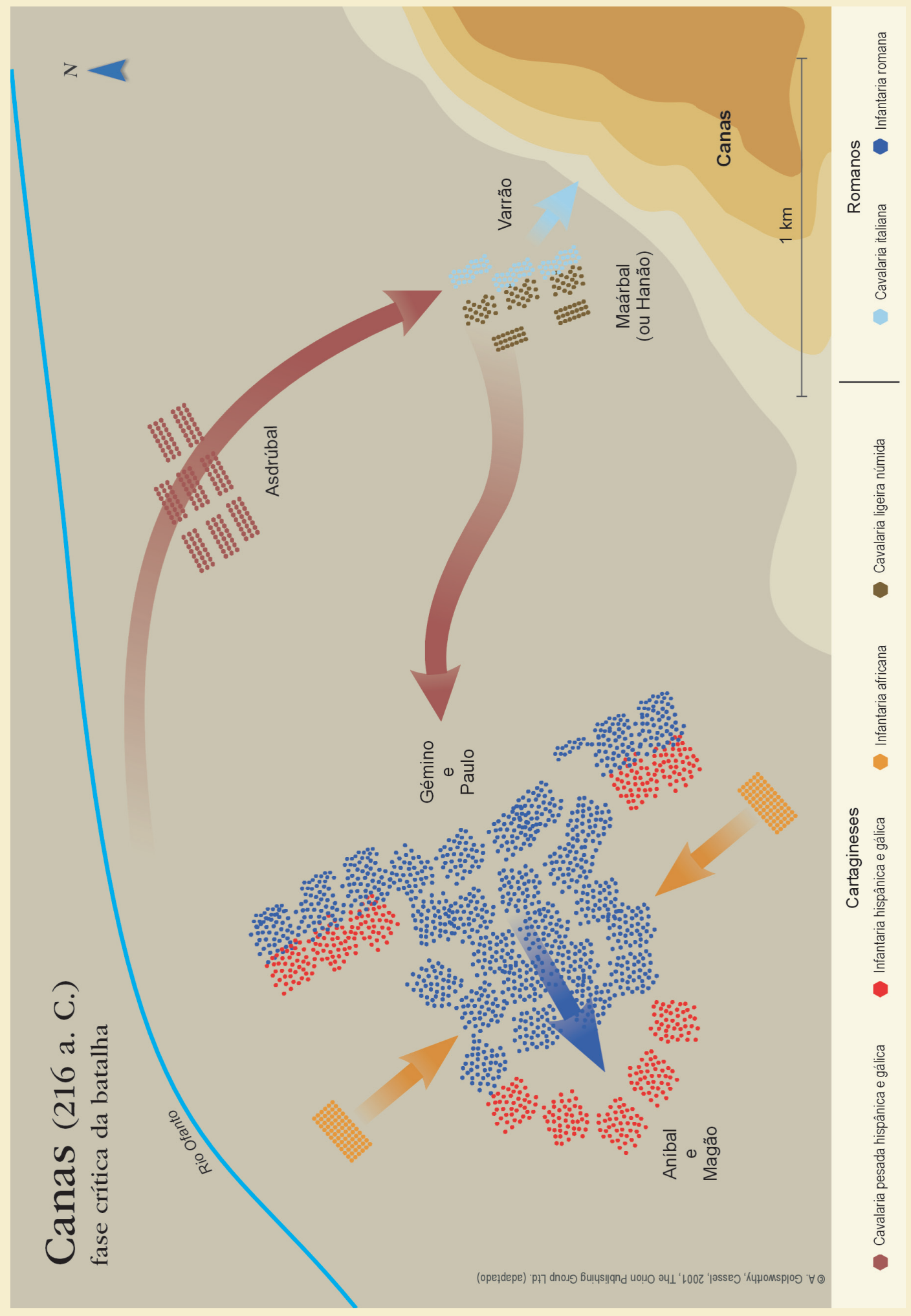


de Alexandre Magno). A cunha avançada foi-se desfazendo e os Romanos aproveitaram para começar a entrar por ela, empurrando os adversários cada vez mais para sudoeste.

Os legionários sabiam bem que neste género de batalhas ganhava quem insistia mais, e a perspetiva de uma vitória sobre um inimigo formidável há de ter inebriado os seus ânimos. Gémino e Paulo iam injetando cada vez mais tropas das linhas recuadas no centro avançado do terreno, procurando aprofundar a brecha num campo estreito e que o dispositivo cartaginês em forma de crescente havia tornado ainda mais acanhado. Os tribunos militares das legiões (em geral seis por cada uma delas) faziam o melhor que podiam para dirigir um combate em que era cada vez menos nítida a separação entre as diferentes unidades táticas. Do lado cartaginês, também Aníbal e Magão, assim como os seus oficiais mais jovens e os chefes das tribos aliadas, incitavam os seus a resistir. Porém, a pressão dos hastati e, depois, também a dos principes (e talvez a dos triarii) mandados avançar por Gémino e por Emílio Paulo tornou-se insuportável e o centro cartaginês rompeu mesmo. Os Romanos animaram ainda mais e perseguiram os adversários, perpetrando uma cruel matança que sabia também a descarga de ódios e de medos.

Todavia, era cedo demais para cantar vitória. É que, nesse preciso momento, Aníbal jogou a sua cartada mais surpreendente: as duas colunas da infantaria pesada líbia, colocadas em zona recuada e semilateral do terreno, formaram duas hastes viradas para o centro e avançaram em simultâneo, pressionando os flancos dos Romanos que progrediam em perseguição dos adversários. De repente, tudo mudou de figura: os Romanos eufóricos que chacinavam os inimigos viram-se subitamente entalados lateralmente entre dois corpos pesados equivalentes a duas legiões e que reuniam a fina flor do exército cartaginês! Não houve capacidade de resposta e é até possível que muitos Romanos não se tenham apercebido imediatamente de que se tratava de tropas hostis...

Este movimento de tenaz apanhou de surpresa a infantaria pesada romana, mas o pesadelo não se ficou por aqui. É que, entretanto, Asdrúbal, depois de pôr em debandada o flanco direito romano, tinha acorrido em auxílio da cavalaria ligeira númida, que combatia ainda a asa esquerda romana liderada por Varrão. Também aqui, de repente o cenário mudou de 
figura: o equilíbrio numérico deixou de existir e a sorte da batalha ficou definitivamente traçada. Ao avistarem a cavalaria de Asdrúbal, o flanco esquerdo romano e o próprio Varrão bateram em retirada. Asdrúbal ordenou aos númidas que perseguissem os romanos em fuga (coisa que eles faziam com destreza) e deslocou-se mais uma vez no campo de batalha, desta feita para executar o golpe de misericórdia: um ataque a cavalo sobre a retaguarda romana. Com isto, 50000 homens da infantaria pesada romana (mais os cerca de 20000 velites empregues na fase inicial da batalha) viram-se quase completamente cercados pelo exército púnico. O resultado só podia ser a aniquilação completa do mais poderoso exército jamais reunido na história de Roma. Aníbal Barca soubera tirar genialmente partido da força bruta e da capacidade rompedora do adversário para derrotar, em sua própria casa, um exército que lhe era quase duas vezes superior em número.

\section{Chacina e fuga}

A batalha, embora decidida a favor dos Cartagineses, prosseguiu ainda durante algum tempo, com os Romanos a resistirem estoicamente. Mas os manípulos já se misturavam uns com os outros, as linhas haviam perdido toda a sua definição e os oficiais já pouco ou nada podiam fazer. Mais valia retirar de forma organizada, mas a concentração de homens e cavalos, a estreiteza do terreno e o dispositivo de envolvimento utilizado pelo exército púnico na fase final do combate também não favoreciam muito esta possibilidade.

A fuga em desordem e, com ela, a chacina brutal não puderam ser evitadas. Ao contrário de Varrão, o cônsul Emílio Paulo morreu no combate e, com ele, a maior parte do imenso exército romano. Tito Lívio avança a estimativa de perdas mais plausível, ao indicar acima de 50000 baixas (isto é, mais de 50\% do exército romano), decompostas desta forma: 45500 soldados de infantaria e 2700 cavaleiros mortos; mais 3000 infantes e 1500 cavaleiros capturados no imediato. Entre os cadáveres contavam-se, além do de Paulo, o do procônsul Servílio Gémino, o do ex-magister equitum de Fábio (Minúcio Rufo), os dos dois questores dos cônsules (Lúcio Atílio e Lúcio Bibáculo), os de 29 dos 48 tribunos militares e ainda os de 80 per- 
sonalidades de alto gabarito (entre senadores e indivíduos já apontados para este cargo). Nunca uma derrota militar tinha atingido tão fortemente a sociedade romana e a sua elite (pois também a Ordem Equestre, que tinha fornecido uma parte importante da cavalaria, sofrera inúmeras baixas).

Do lado cartaginês, Políbio refere a existência de 5700 mortos (c. 11,5\% dos efetivos), enquanto Lívio fala em 8000 baixas (16\%). Números duas a três vezes superiores à média registada no seio dos exércitos vencedores nas batalhas da Antiguidade...

Quanto aos sobreviventes, fugiram para onde puderam. Os que haviam permanecido nos dois acampamentos romanos ficaram em estado de choque e muitos nem tiveram capacidade e frieza suficientes para se pôr em fuga. Os 10000 homens do acampamento principal quase não tinham participado no combate, exceção feita a um ataque abortado ao arraial cartaginês. Por isso, estavam ainda razoavelmente organizados sob os seus oficiais. Terão enviado mensagens aos companheiros do acampamento mais pequeno para que se lhes juntassem e fugissem juntos para Canosa (vinte e poucos quilómetros a sudoeste). A resposta não terá sido a melhor, mas ainda assim alguma força se organizou sob os tribunos Semprónio Longo e/ou Gneu Octávio, à qual se terá juntado uma parte da guarnição do acampamento principal. Reunidos estes dois grupos de fugitivos, escaparam para Canosa perto de 4000 peões e 200 cavaleiros. Os que optaram por ficar nos arraiais romanos (pois receavam a passagem junto ao acampamento cartaginês e esperavam poder beneficiar da habitual indulgência de Aníbal) foram obviamente capturados. Assim, mais 12800 soldados romanos (metade dos quais tropas aliadas) engrossaram a lista de prisioneiros. A estes devemos ainda somar 2000 romanos apanhados em Canas. Melhor sorte teve Varrão e os 50 a 70 cavaleiros que com ele fugiram aquando da debandada do flanco esquerdo romano: conseguiram escapar para Venúsia, a sul de Canosa, onde foram bem acolhidos e auxiliados pela população local (tal como de resto sucederia em Canosa). Por iniciativa de quatro tribunos (entre os quais o filho de Fábio Máximo e o jovem Públio Cornélio Cipião, o tal que salvara o pai na batalha de Ticino), os dois grupos de fugitivos acabaram por se reunir em Canosa. Deste modo, Canosa (para onde o próprio Varrão se dirigiu) tornou-se um ponto de reagrupamento de todos os Romanos e 
aliados que conseguiram escapar à desgraça, individualmente ou em grupo. Isso terá permitido juntar perto de 10000 homens e com eles formar de imediato, com o pragmatismo típico dos Romanos, duas legiões completas.

\section{Depois da batalha}

A notícia da estrondosa derrota do exército dos dois cônsules caiu que nem uma bomba em Roma. À humilhação pelo destroço do maior exército da história romana associava-se a dor pela morte de milhares de cidadãos (muitos deles das melhores famílias da aristocracia) e uma dúvida cruel: o que iria Aníbal fazer a seguir?

No Senado, Fábio Máximo assumiu a iniciativa de uma reação necessária: o luto público foi proibido, a guarda da capital do Império foi reforçada e foram também enviados batedores para as estradas a sul, com o objetivo de detetar uma eventual aproximação do exército púnico. No entanto, isso não sucederia.

Em Canas, segundo o relato de Tito Lívio, Maárbal, que possivelmente comandara a cavalaria ligeira númida no flanco direito cartaginês, desafiou Aníbal a marchar de imediato sobre Roma e a comemorar o seu triunfo dentro de cinco dias com um jantar no Capitólio... Aníbal, possivelmente exausto física e psicologicamente, terá respondido que precisava de tempo para avaliar esse projeto. A isto terá retorquido Maárbal, seguindo a mesma fonte, com uma frase célebre: "Certamente nenhum homem foi abençoado com todas as dádivas de Deus. Tu sabes, Aníbal, como ganhar uma batalha; mas não sabes como usar a tua vitória”.

Ainda hoje os historiadores militares discutem sobre a razão por que Aníbal não avançou sobre Roma. Afinal, uma vitória daquela envergadura criava condições únicas para isso. É certo que Roma estava a mais de $400 \mathrm{~km}$ de distância, mas não é de crer que o exército púnico encontrasse grande oposição pelo caminho, ou que tivesse dificuldade em abastecer-se onde e como desejasse. No entanto, Aníbal tinha a experiência do assédio, arrastadíssimo, de Sagunto e não estava equipado com maquinaria de cerco nem seria grande adepto deste género de operações. O general cartaginês também 
não podia saber exatamente até que ponto a capital do Império estava bem defendida e tinha de admitir que os Romanos recusassem capitular logo de início e se mostrassem determinados na defesa da sua cidade. Um cerco fracassado debilitaria o prestígio de Aníbal e comprometeria o seu principal objetivo: alargar consideravelmente o seu número de aliados em Itália, de modo a isolar Roma e a obrigá-la a assinar um tratado favorável a Cartago.

Assim, Aníbal Barca optou por permanecer algum tempo no campo de batalha, sepultando os seus mortos e tratando dos feridos. De entre os 8000 cidadãos capturados, escolheu 10, que enviou a Roma para negociar os resgates e, se possível, a paz. Aníbal acreditava que, depois de uma batalha que dizimara mais de $10 \%$ do potencial militar de Roma, o Senado quisesse negociar. Mas enganou-se. Roma, consultado o oráculo de Apolo em Delfos, castigadas duas virgens vestais e feitos alguns sacrifícios humanos (o que era raro), recusou receber o emissário cartaginês e tão-pouco se interessou pelo resgate dos prisioneiros... A decisão desapontou Aníbal, que no entanto beneficiou da submissão de uma boa parte da Itália do Sul (aliados de Roma) nos finais de 216 a. C., facto que lhe permitiu começar a praticar um outro tipo de guerra, com diversas bases operacionais, mas também com muito mais aliados para proteger.

Em Roma, entretanto, multiplicavam-se as medidas de reação à crise. Varrão foi mandado regressar (sendo bem acolhido na cidade) e Marco Júnior Pera foi nomeado ditador, cabendo-lhe a ele (e a Tibério Semprónio Graco, seu magister equitum) iniciar o processo de reconstrução do exército romano. Confirmando os enormes recursos humanos da República, rapidamente foram recrutadas duas novas legiões, incorporando jovens de 17 anos e escravos libertados e recorrendo a armamento invulgar, como troféus da guerra contra os Gauleses ou peças retiradas dos templos. No entanto, no imediato, não foi possível mobilizar mais de 1000 cavaleiros, tal havia sido a sangria sofrida pela Ordem Equestre em Canas.

Nas eleições consulares de 215 a. C., o voto recaiu em Lúcio Postúmio Albino e em Tibério Graco. Todavia, o primeiro depressa caiu numa emboscada na Gália Cisalpina e acabou morto, juntamente com uma parte importante do seu exército. Por isso, foi substituído por Marco Cláudio Marcelo, um experiente pretor que já havia sido cônsul e que tinha combatido 
na Sicília (durante a Primeira Guerra Púnica) e na Gália Cisalpina, com Gneu Cornélio Cipião (em 222 a. C., tendo tomado Milão, a maior cidade dos Ínsubres). Em 214 a. C., o próprio Fábio Máximo e Marcelo foram eleitos cônsules e, nos anos seguintes (em que foram sendo, intermitentemente, reeleitos), geriram o melhor possível, com êxitos e derrotas relativamente marginais, a guerra contra Aníbal, centrada sobretudo na Apúlia (entre Herdoneia e Tarento) e na Sicília (famoso cerco de Siracusa pelos Romanos, com os de dentro a defenderem-se com engenhos de cerco desenhados por Arquimedes, nativo desta cidade).

Aos poucos, o jovem exército romano ia ganhado experiência concreta da guerra, enquanto o exército de Aníbal via avolumarem-se as suas dificuldades. Tanto mais que Cartago não concedeu os apoios que Magão ali fora pedir, parecendo claro que na capital púnica começava a aumentar a força de um partido que se opunha à família dos Barca. Sem um grande porto para receber reforços significativos de África, com muitos aliados para defender (incluindo Cápua, que em 212 a. C. se viu cercada pelos Romanos e que Aníbal tentou salvar organizando então, sem sucesso, uma marcha sobre Roma), o exército púnico foi ficando progressivamente encurralado no sul da Itália. A situação agravar-se-ia ainda mais quando o exército de Asdrúbal se viu cercado e aniquilado pelos Romanos quando tentava unir forças com o de Aníbal, o mesmo tendo sucedido com Magão, que foi travado e vencido no Norte de Itália, não conseguindo por isso juntar-se ao irmão.

O Senado continuou a apoiar as campanhas romanas na Hispânia e na Sicília, de que resultou a expulsão dos Cartagineses destas regiões, ao mesmo tempo que lavrou um tratado de paz com o rei Filipe V da Macedónia (com quem Aníbal desejava aliar-se), o que pôs termo à chamada Primeira Guerra Macedónica (214-205 a. C.), permitindo a Roma concentrar-se no seu inimigo principal.

Finalmente, em 203 a. C., Aníbal retirou de Itália (a partir de Crotona, na Calábria), respondendo ao apelo de Cartago, que desde o ano anterior se via a braços com uma invasão romana do Norte de África liderada por Públio Cornélio Cipião (o veterano de Ticino e de Canas, que entretanto se distinguira na Hispânia: batalha de Ilipa, em 206 a. C.). Em 202 a. C., os exércitos de Aníbal e de Cipião (que casara com uma filha de Emílio Paulo) 
enfrentar-se-iam em Zama, na atual Tunísia, em batalha campal. Largamente diminuído numa das suas melhores armas (a cavalaria), Aníbal foi desta feita vencido pelos Romanos: a infantaria legionária superou bem a linha de elefantes que Aníbal colocara na sua frente e atacou a infantaria cartaginesa sem cair no engodo de afunilar a sua investida pelo centro (para o efeito, Cipião triplicou a frente romana por meio do avanço da segunda e terceira linhas das legiões para a esquerda e para a direita, respetivamente), ao mesmo tempo que a cavalaria romana e aliada, incluindo muita cavalaria númida, envolviam o exército púnico por trás, com isso decidindo a jornada.

Cartago, com o seu exército praticamente destruído, acabou por se render em 201 a. C., pondo assim termo à Segunda Guerra Púnica. Quanto a Aníbal, sobreviveu ao desastre de Zama e chegou ainda a desempenhar funções oficiais de relevo em Cartago. Mas as rivalidades políticas a que estava sujeito nesta cidade e o natural desejo de vingança de muitos senadores romanos obrigaram-no a partir para o exílio. Durante vários anos, serviu como comandante mercenário no Oriente helenístico, continuando a dar expressão concreta ao seu ódio contra Roma. Até que, constantemente perseguido por agentes romanos, pôs termo à sua própria vida na Bitínia, em 183 a. C. Tinha já mais de 60 anos e, nesse mesmo dia, tornou-se uma das maiores lendas da história militar de todos os tempos.

\section{Fontes principais}

Políbio, Histórias (Livro III, 113-118). Utilizámos a tradução inglesa de Ian Scott-Kilvert: Polybius, The Rise of the Roman Empire, Penguin Books, 1979.

Tito Lívio, História de Roma (Livro XXII, 43-61). Utilizámos a tradução inglesa de Aubrey de Sélincourt: Livy, The War with Hannibal, Penguin Books, 1972.

\section{Leitura-base}

Adrian Goldsworthy, Cannae. Londres, Cassell, 2001.

\section{Leituras complementares}

Adrian Goldsworthy, A Queda de Cartago. As Guerras Púnicas, 265-146 a. C. Trad. port., Edições 70, 2009 (ed. orig.: 2000).

Adrian Goldsworthy, Generais Romanos. Os homens que construíram o Império Romano. Trad. port., Lisboa, Esfera dos Livros, 2007.

Iain Dickie, "Cannae, 216 BC", in Battles of the Ancient World, 1285 BC-AD 451. From Kadesh to Catalunian Field. Londres, Amber Books, 2007 (pp. 108-119).

J. Lazenby, Hannibal's War. Warminster, 1978.

T. Cornell, B. Rankov, Ph. Sabin, The Second Punic War: A Reappraisal. Londres, 1996. 


\section{CAPÍTULO 3}

\section{ADRIANOPLA (378): QUANDO O OCIDENTE MUDA DE MÃOS}

\section{Da República ao Império}

A morte de Aníbal, em 183 a. C., silenciou o mais formidável general que os Romanos haviam enfrentado, mas não encerrou as Guerras Púnicas. O arrefecimento do conflito com Cartago permitiu a Roma empenhar-se noutras frentes externas, designadamente travando com êxito diversas guerras contra os Macedónios, terminadas de vez em 148 a. C. Nessa altura, porém, já tivera início uma terceira e última Guerra Púnica (149-146 a. C.), que acabaria com a destruição da cidade de Cartago por Cipião Emiliano. Seguiu-se a guerra contra o rei da Numídia, Jugurta (112-105 a. C.), que os Romanos também venceriam graças à capacidade de comando do célebre cônsul Gaio Mário.

Nesta época, Roma tinha já um curriculum impressionante de vitórias militares dentro e fora da Península Itálica, e Mário percebeu que estava na altura de proceder a uma reforma global do exército. Este tornou-se então uma força profissional e permanente, com o recrutamento dos legionários doravante aberto a todos os cidadãos (e não apenas àqueles capazes de adquirir o seu próprio equipamento) e com métodos de seleção e de treino muito mais rigorosos. A militância nas legiões deixou de ser encarada como uma obrigação que, ocasionalmente, impunha aos cidadãos uma interrupção pontual na sua vida comum e converteu-se numa carreira e até - em muitos casos - num meio para fugir à pobreza. 
As décadas seguintes da história da República de Roma (entre 100 e 50 a. C.) foram marcadas por uma fervilhante intervenção militar, interna e externa, com a Guerra Social de 91-88 a. C. (a última grande rebelião dos aliados itálicos de Roma), a guerra civil de 88 a. C. (que conduziu à ditadura de Sula), as diversas guerras contra Mitridates, rei do Ponto (entre 88 e 66 a. C., na Ásia Menor), as campanhas de Sertório na Hispânia (entre 82 e 72 a. C.), a Guerra Servil de 73-70 a. C. (famosa revolta dos escravos liderados por Espártaco, esmagada com mão de ferro por Marco Licínio Crasso), a operação de limpeza da pirataria no Mediterrâneo por Pompeu Magno (em 67 a. C.), ou as vitoriosas campanhas de Júlio César na Gália, contra Vercingetorige e outros líderes gauleses (entre 58 e 51 a. C.). Durante estes 50 anos, o exército romano não cessou de evoluir a todos os níveis: estratégia, tática, logística, armamento, treino e comando, nomeadamente.

Os vinte anos que se seguiram (50 a 30 a. C.) seriam de suma importância na história política romana. O tradicional poder da República, assente num Senado forte e numa participação ativa dos cidadãos na vida pública, revelou tendência para se concentrar nas mãos de pequenos grupos de notáveis. Uma aliança estabelecida em 60 a. C. entre César, Pompeu e Crasso dera origem ao Primeiro Triunvirato, que acabaria por redundar na guerra civil de 49-45 a. C., ganha por César. Poucos anos mais tarde, a ditadura de Júlio César seria interrompida pelo seu assassinato brutal às portas do Senado, em 44 a. C. Seguiu-se uma nova guerra civil e um Segundo Triunvirato, reunindo Marco António, Otaviano (sobrinho de César e seu filho adotivo) e Lépido. A aliança, porém, não vingou e acabaria por conduzir à batalha naval de Áccio, em 31 a. C., em que Otaviano derrotou Marco António e a sua aliada Cleópatra, rainha do Egito. Era a morte anunciada da República: após um curto período de transição, Otaviano assumir-se-ia em 27 a. C. como o primeiro imperador da história de Roma.

\section{A máquina militar romana}

O principado de Otávio Augusto prolongou-se até 14 d. C. À sua morte, e se excetuarmos a conquista da Dácia (atual Roménia) por Trajano (entre 101 e 106 d. C.), o Império tinha praticamente atingido a sua extensão máxima. 

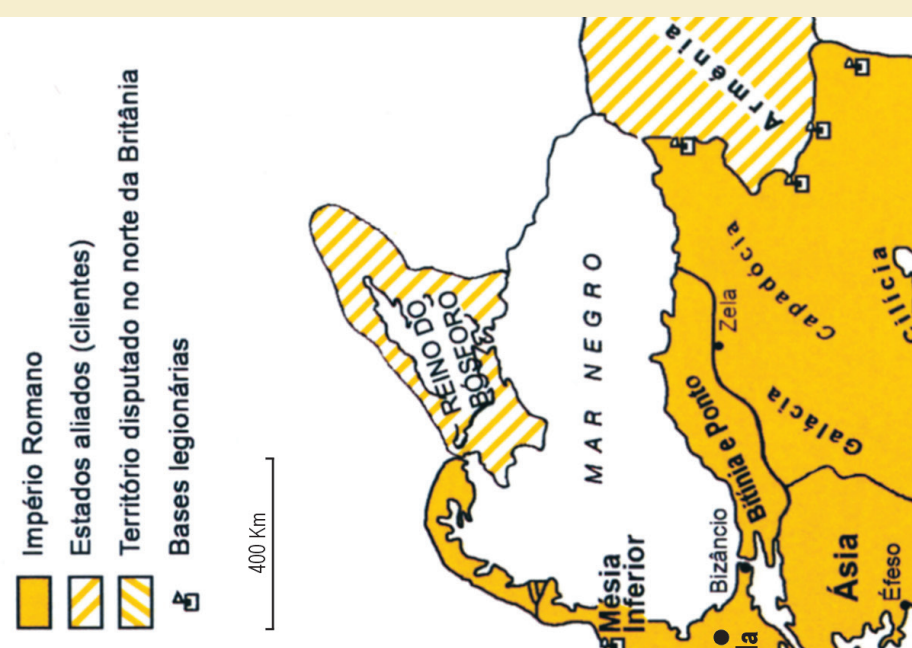
Ou seja, o exército romano, agora profissionalizado, pusera de pé o maior império de que há memória na longa história do mundo ocidental. É extraordinário como uma pequena cidade fundada na planície do Lácio, virada ao mar Tirreno, conseguiu construir um Estado que se estendia do Atlântico à Mesopotâmia e das regiões mais férteis do Norte de África até às Ilhas Britânicas!

O pilar desta construção era, naturalmente, o exército romano, a maior máquina militar que jamais existiu à superfície da Terra. Na época do sucessor de Augusto (o seu enteado Tibério: 14-37), estima-se que essa máquina envolvesse perto de 300000 homens e exigisse um financiamento anual na ordem dos 60 a 70 milhões de denários. Ao longo do Alto Império (sécs. I e II), estes números tenderiam ainda a aumentar, e admite-se hoje que a despesa com o exército tenha chegado a representar $90 \%$ do orçamento do Império Romano! Valores exorbitantes para os nossos dias, mas indispensáveis para manter de pé uma máquina que, ao tempo de Tibério, envolveria:

i) cerca de 25 legiões (cada qual com perto de 5000 soldados, dos quais apenas 120 eram cavaleiros) distribuídas por todo o espaço imperial;

ii) um número idêntico (isto é, c. 125000 homens) de "tropas auxiliares" recrutadas entre a população não cidadã, sobretudo entre os habitantes bárbaros das áreas de fronteira do Império (atraídos pela estabilidade da carreira militar e pela possibilidade de obter a cidadania romana no momento da desmobilização);

iii) perto de 40000 homens afetos à marinha, que, a partir de duas bases principais (Miseno e Ravena) ou através de algumas flotilhas provinciais, controlava o Mediterrâneo e os principais cursos de água e mares periféricos (como o Mar Negro);

iv) e uma forte guarnição militar em Roma, com cerca de 10000 homens e onde pontificava a célebre Guarda Pretoriana, uma tropa de elite recrutada entre cidadãos romanos, com apenas 20\% de cavaleiros, e tendo como símbolo o escorpião.

A eficiência deste exército é deveras impressionante e foi ela que permitiu preservar a integridade de uma imensa superfície territorial ao longo 
de séculos (um feito que não esteve ao alcance de Alexandre Magno, de Napoleão ou de Hitler, para citar apenas três exemplos emblemáticos). Em nosso entender, são sobretudo seis os segredos que se escondem por detrás de tantos êxitos da máquina militar romana.

Antes de mais, um nível muito elevado de organização e de disciplina. Sem isso não teria sido possível deslocar, alimentar e equipar centenas de milhares de soldados. Recorde-se que os Romanos construíam acampamentos de marcha fortificados por apenas uma noite e que as suas linhas de batalha eram organizadas com uma precisão quase cirúrgica.

Em segundo lugar, uma notável capacidade de adaptação e de integração. Repare-se como os Romanos foram capazes de adotar armamento de outros povos (desde as cotas de malha dos Gauleses até às espadas curtas, ou gládios, dos Hispânicos), do mesmo modo que, em especial a partir dos finais do séc. II, se mostraram capazes de acolher elementos bárbaros nas suas hostes ou de incorporar soluções táticas próprias dos povos que tinham submetido (como os fundibulários das Ilhas Baleares, os arqueiros da Síria ou a cavalaria couraçada do Oriente). No entanto, faziam tudo isso sem abdicar da sua identidade própria: o modelo da legião (no Alto Império dividida em 10 coortes, cada qual com seis centúrias de 80 soldados cada, exceto a primeira coorte, que tinha apenas cinco centúrias mas com o dobro dos efetivos) não existiu em mais parte nenhuma do mundo; e o sistema de comando (encabeçado por um legado em cada legião, acolitado por um senador-tribuno, um prefeito do acampamento, cinco tribunos da Ordem Equestre, um tribuno para a cavalaria e 59 centuriões) também não era partilhado por mais nenhum exército.

Um terceiro segredo resultava de uma persistência e determinação raras. Mesmo quando tudo parecia perdido, os Romanos davam a volta por cima e acabavam por vencer a guerra. Assim fora já nas Guerras Púnicas e assim voltaria a ser em muitas outras disputas ao longo do Alto Império. Entre os Romanos, o espírito militar era, de facto, tremendo.

Em quarto lugar, uma cruel impiedade para com os adversários: os Romanos não gostavam de ter de lutar muitas vezes contra o mesmo inimigo. Por isso, não hesitaram em destruir cidades rivais, como Cartago ou Numância (junto ao rio Douro, em 133 a. C.). E mesmo quando faziam a paz (a célebre Pax Romana), impunham-na de uma forma leonina e humilhante. 
O quinto trunfo romano, este mais (re)conhecido, tinha que ver com um treino muito intensivo, tanto em tempo de guerra como em tempo de paz, diariamente, com armas embotadas mas bem mais pesadas do que as armas reais e com uma variedade enorme de exercícios: marcha, corrida, salto, natação, arremesso de dardos, esgrima e hipismo, nomeadamente. Um dito célebre lembra que, para os Romanos, os treinos eram verdadeiras batalhas sem derramamento de sangue, e as batalhas não mais do que treinos sangrentos...

Finalmente, o sexto segredo: uma flexibilidade tática rara no mundo antigo (ainda muito dominado pelo modelo das grandes falanges), que era proporcionada pelas diversas subdivisões da legião (as coortes, as centúrias e os manípulos, que agrupavam cada duas centúrias) e reforçada ainda pelo recurso ocasional a destacamentos (uexillationes) com missões específicas e pelo uso criterioso de reservas.

Com tudo isto, a máquina militar romana concebida no período final da República afirmou-se ao longo do Alto Império como muito difícil de bater. A partir das reformas de Mário, a carreira militar abriu as portas do futuro a muitos jovens romanos, que, após serem cuidadosamente recrutados e testados em exames médicos, eram inscritos e tatuados com apenas 18 a 21 anos de idade, cumprindo depois carreiras muito longas, que podiam ir dos 16 anos na guarnição de Roma até aos 28 anos na marinha. Quando, por fim, eram licenciados, os soldados romanos não estavam desamparados: dos salários que lhes eram devidos, o sistema militar tinha tido o cuidado de cativar, ao longo dos anos, uma 'poupança obrigatória' que era entregue aos veteranos na hora do adeus às armas. Com esse pecúlio, completado com outros subsídios em dinheiro ou em terras, os velhos soldados podiam estabelecer-se por conta própria, trabalhando na agricultura ou no comércio e formando muitas vezes colónias nas proximidades dos principais acampamentos militares, algumas das quais dariam origem a importantes municípios.

A dura e perigosa carreira do legionário também tinha, pois, importantes compensações: um salário muito razoável (entre 225 e 300 denários por ano, no séc. I d. C., pagos ao trimestre ou ao quadrimestre), uma alimentação bastante variada e abundante (cereal; carne de vaca, de carneiro ou de galinha; peixe e marisco; legumes, feijões e lentilhas; vinho e azeite), 
divertimentos regulares (banhos, espetáculos de gladiadores) e, no momento da reforma, a certeza de uma reintegração social tranquila. Não espanta portanto que, a par dos deuses, da terra e do Direito, as armas ocupassem um lugar especial no coração dos Romanos, pelo menos no período final da República e durante as primeiras dinastias imperiais (os Júlios-Cláudios, os Flávios, os Antoninos), que, ao longo do Alto Império, espalharam a glória de Roma. Todavia, nenhum império é eterno (nem mesmo a Roma aeterna!) e, tanto dentro como fora das fronteiras, as contradições e os perigos aumentavam, prenunciando tempos difíceis...

\section{A Crise}

Um pouco antes de meados do séc. III, abateu-se sobre o Império Romano uma profunda crise, cujos efeitos marcariam para sempre os destinos da sua parte ocidental. Esta crise teve uma origem militar, resultando da pressão conjugada dos Germanos, a norte, e dos Persas, a leste. A norte, os bárbaros que já estavam próximos da fronteira (o limes) foram empurrados pelos povos recém-chegados, numa espécie de efeito de 'bola de bilhar' (ou 'efeito dominó') com origem na Ásia Central; a leste, uma revolução substituíra os Partas Arsácidas pelos Persas Sassânidas, que eram de uma grande intolerância religiosa e de um nacionalismo bastante agressivo. Ambas as circunstâncias provocaram uma desorganização generalizada, sensível a diversos níveis: político, com os soberanos a serem postos e depostos pelos soldados e o Império convertido numa "monarquia absoluta temperada pelo assassinato" (Yann Le Bohec); económico, com a ruína do comércio, das cidades e dos campos; social, com o crescimento assustador do banditismo; e até moral, com a perturbação das consciências, a sensação de que os desastres traduziam a ira dos deuses e as consequentes perseguições aos cristãos, pois estes não adoravam Júpiter nem Marte...

Neste enquadramento, a estratégia tornou-se mais defensiva e, no plano tático, acentuou-se a tendência para o uso da cavalaria couraçada e dos arqueiros. Ao mesmo tempo, agravaram-se os problemas de recrutamento militar (pois o serviço era cada vez mais perigoso e mal pago), e 
a importante marinha começou a definhar por falta de verbas. Entre 235 e 260, sucederam-se as perdas territoriais em praticamente todas as frentes. Os líderes mostravam-se impotentes perante a dimensão da crise, e o próprio imperador Valeriano foi capturado durante uma ofensiva contra os Persas, sendo executado por volta de 260. Invasões e usurpações do trono eclodiram então em simultâneo e a situação só não se tornou desastrosa porque, em 260, assumiu o trono um homem decidido e com forte sentido reformador: Galieno. Este imperador recebeu uma herança pesadíssima e coube-lhe por isso tomar uma série de medidas de natureza militar, de que destacaremos: a criação de uma nova guarda pessoal; a modificação do comando das legiões, interditando aos senadores a carreira militar; o reforço do papel tático e estratégico dos cavaleiros legionários (cujo número subiu de 120 para 726 por legião); e a criação de novas unidades montadas e a valorização das já existentes, conduzindo ao nascimento de uma reserva móvel estacionada atrás da fronteira.

A morte em combate de Galieno, em 268, entregaria o poder a Cláudio II, grande incentivador do recrutamento em massa de bárbaros. Seguiu-se Aureliano (270-275), um imperador que tentou reforçar a unidade do Império através do culto solar e que protagonizaria múltiplos combates. O exército romano contava agora com cerca de 35 legiões, distribuídas deste modo: 3 na Bretanha (atual Grã-Bretanha), 16 ao longo do Reno e do Danúbio (em especial contra os Alamanos e os Godos), 12 no Oriente (contra os Persas), 2 em África (uma das quais no Egito), 1 na Hispânia e 1 na Península Itálica - o que mostra bem de onde vinha o perigo principal. A Aureliano sucederiam Tácito e uma série de outros imperadores com reinados curtos e muitos problemas para resolver. O declínio da marinha romana também causava preocupação, pois a pirataria grassava na Mancha e nas costas da Bretanha. A situação afigurava-se, portanto, muito grave.

\section{A época de Diocleciano}

Diocleciano (284-305) e Constantino I (324-337) dividem entre si o protagonismo das reformas militares operadas a partir de finais do séc. III. Durante muito tempo, acreditou-se que aqueles dois imperadores teriam 
criado um novo sistema defensivo, com a divisão do exército romano em dois: uma reserva móvel atrás da fronteira, composta pelas melhores tropas (os comitatenses), e as outras unidades no limes, formadas por medíocres 'soldados camponeses' (os limitanei). Porém, recentemente Le Bohec sugeriu algo de muito diverso: "O dispositivo militar adotado não se organizava certamente segundo faixas paralelas à fronteira, com os limitanei à frente e o comitatus atrás. É verdade que os limitanei estão documentados, tal como os comitatenses, e aliás também os palatini (unidades de elevado estatuto e prestígio), frequentemente esquecidos. Mas a divisão entre estes tipos de soldados não pertencia ao domínio da estratégia (linha da frente versus retaguarda); ela decorria antes da tática e das honrarias (unidades ordinárias versus unidades de elite)". Assim, reconhecemos hoje uma estratégia militar romana com um recorte no espaço bem distinto. Foram postos no terreno três grandes exércitos, de forma perpendicular à fronteira e como solução para travar os principais inimigos: os exércitos das Gálias, da Ilíria (antiga Jugoslávia) e do Oriente, respetivamente perante os Alamanos, os Godos e os Persas.

Mais do que nunca, o Império sentia-se ameaçado - e tinha razões para isso. Na maior parte dos casos jogou à defesa, sem no entanto deixar de tomar a ofensiva sempre que as condições o permitiam. O objetivo estratégico principal passava pela segurança de Roma e da Península Itálica, o que implicou dificuldades cada vez maiores perante a agressividade e a qualidade guerreira dos inimigos germanos: os Alamanos, os mais temidos, e os Godos.

$\mathrm{Na}$ parte ocidental, o imperador - que ocupava o centro do poder, sempre acompanhado pelas unidades palatinas e assessorado por um consilium de oficiais onde se destacavam os "mestres das milícias" criados por Constantino I - sabia bem que a segurança de Roma passava sobretudo pelo controlo da Gália e da Ilíria, as portas de acesso ao coração da Península Itálica. O tempo, porém, não jogava a favor: durante o Baixo Império, uma boa parte da Gália (sobretudo a norte) afundou-se numa crise generalizada, que em grande medida resultava das guerras contra os vários povos germânicos. Vale a pena examinar um pouco mais em pormenor a ação de Diocleciano e de Constantino I.

Ao assumir o poder em 284, Diocleciano encontrou uma situação militar assaz complicada, tanto na Grã-Bretanha como nas linhas do Reno e do 
Danúbio, e também a leste, com a ameaça persa. Tranquilidade, só relativa e apenas na Península Ibérica e nas regiões mediterrânicas da Península Itálica e de África, embora mesmo aí surgissem revoltas. Perante este quadro terrível, Diocleciano tratou de reforçar o poder político e o poder militar e de aproximá-los da fronteira. Fundou, com Maximiano, o regime político da "diarquia imperial" (dois Augustos dividindo entre si o comando do Império) e, mais tarde, a "tetrarquia imperial" (que associava, aos anteriores, dois Césares de dignidade inferior, no caso Galério e Constâncio Cloro). Tratava-se de um sistema hierarquizado que criava quatro exércitos, cada qual defendendo uma parte do Império. Diocleciano era um homem com gosto pela autoridade e pelo serviço do Estado, e todos os tetrarcas eram oficiais e oriundos da Ilíria, ou seja, tratava-se de homens convictos do valor da romanidade. Buscaram o apoio dos deuses e encetaram duras perseguições aos cristãos. Estrategicamente distribuídos, os tetrarcas intervieram um pouco por todo o Império, pois a situação nas fronteiras era agravada por contínuos golpes de Estado.

A oriente, Diocleciano obteve também importantes sucessos: no Egito; contra os Sarracenos; e, sobretudo, contra os Persas, o que conduziria à Paz de Nisibe (298), garantida após a reconquista da Arménia e a chegada de um grande exército romano ao sul da Mesopotâmia. Esta paz, com resultados imediatos e efeitos a longo prazo, foi humilhante para os Persas, pois garantiu o controlo romano sobre a Arménia e a Ibéria do Cáucaso (na atual Geórgia) e a anexação de todo o Norte da Mesopotâmia.

Estabilizada a situação, Diocleciano investiu nas reformas militares. Entre as muitas que costumam ser-lhe atribuídas, algumas delas sem fundamento (como os supostos "acampamentos diocleciânicos", que afinal são bem anteriores), devemos realçar quatro. Em primeiro lugar, uma transformação substancial das legiões, com a redução drástica dos efetivos em algumas delas, o que levou à criação de 'microlegiões' (de modo a poder-se dispor de, pelo menos, duas em cada província fronteiriça). Por outro lado, alterações no modelo de recrutamento, que se traduziram no relaxamento do serviço militar obrigatório e na criação de mecanismos de tipo fiscal para a mobilização de homens para a guerra. Em terceiro lugar, o aumento dos efetivos militares, de modo a que cada tetrarca pudesse dispor da sua própria guarda (João "o Lídio", que escreve no séc. VI, refere, para a época de 
Diocleciano, 389704 homens no exército de terra e 45562 na marinha). Finalmente, mas não menos importante, a reconstituição da marinha.

\section{As reformas de Constantino}

A abdicação de Diocleciano e de Maximiano (em 305) abriu um novo período de lutas pelo poder. Depois de algumas tentativas de mediação fracassadas, a guerra civil tornou-se inevitável e dela sairia vencedor Constantino (filho de Constâncio Cloro). Em 324, este ilírio, criado e educado no séquito de Diocleciano, conseguiu uma vitória decisiva sobre o rival Licínio, o que lhe abriu as portas do poder absoluto. Constantino I empenhou-se então a fundo na guerra externa: os seus filhos tiveram vários sucessos na região renana, contra os Alamanos; o próprio imperador bateu os Godos no Danúbio; e o seu filho (e César) Constâncio venceria os Persas. Mas, em 337, no momento em que preparava uma grande ofensiva contra os Persas, Constantino I faleceu.

Constantino I fez uma verdadeira reforma do exército romano, mas fê-la ao sabor das circunstâncias e não seguindo um programa pré-estabelecido. De entre as diversas medidas que tomou, há quatro que merecem destaque. Antes de mais, a dissolução das velhas unidades da guarnição de Roma e da guarda pessoal do imperador, o que implicou a criação de uma nova guarda imperial (as Scholae Palatinae). Depois, a reforma do alto comando, com a criação das referidas três grandes regiões militares: as Gálias (incluindo a Gália, as Germânias, a Bretanha, a Hispânia e a Tingitânia - nos atuais Marrocos e Argélia), a Ilíria (incluindo o restante Norte de África romano, a Península Itálica e a Ilíria) e o Oriente; em cada uma destas regiões, o verdadeiro comando militar estava nas mãos dos "mestres das milícias" (dois por cada região: um da cavalaria e outro, seu subordinado, da infantaria). Em terceiro lugar, a implementação de novos dispositivos táticos, tanto em batalha campal (na batalha de Turim, em 312, o exército romano formou em cunha, com uma reserva que avançou no decurso do combate) como na guerra de cerco. Por fim, a forte incorporação - para colmatar as lacunas de recrutamento - de soldados bárbaros, sobretudo Germanos e Francos. 


\section{O caminho do Oriente}

À morte de Constantino I (337), o Império Romano tinha, portanto, um novo rosto: mais bárbaro, com uma orientação estratégica original e com novas soluções táticas. O desaparecimento deste imperador trouxe uma nova fase de convulsões internas. Os seus três filhos (Constâncio II, Constantino II e Constante) dividiram entre si o Império: era um retorno parcial ao modelo de Diocleciano, agora convertido em "triarquia imperial", com os protagonistas bem unidos por estreitos laços de sangue. No entanto, não resultou, em grande parte devido às ambições de Constâncio II: a luta contra os inimigos externos foi prejudicada por tentativas de golpe de Estado e por combates fratricidas entre os "triarcas".

Chegou então a hora de Juliano, sobrinho de Constâncio II e por este elevado à condição de César com a missão de defender a Gália. Em 356, Juliano assumiu funções e reorganizou o exército romano na região, depressa conseguindo as primeiras vitórias, consolidadas pelo importante triunfo alcançado na batalha de Estrasburgo, em 357, contra os Alamanos.

Os êxitos do sobrinho permitiram a Constâncio II ocupar-se da crescente ameaça protagonizada pelos Persas, inconformados com a Paz de Nisibe. Em 360, Constâncio II solicitou a Juliano que o ajudasse no Oriente, mas o exército romano das Gálias recusou-se a abandonar o 'seu' território e aclamou Juliano como imperador! Aproximava-se uma nova guerra civil, que a morte de Constâncio II acabaria por evitar.

Com o grosso do exército romano sob a sua obediência, Juliano, tornado imperador, lança-se então numa grande aventura no Oriente. As tropas dispõem-se agora a acompanhá-lo longe da Gália. Amiano Marcelino (oficial do exército de Juliano e a nossa principal fonte para o estudo da batalha de Adrianopla) descreve a campanha persa de 363 como uma série de êxitos. Os meios envolvidos são poderosos e os primeiros resultados são encorajadores, devendo-se, em parte, à tímida reação persa. Os Romanos atingem o ponto mais meridional do seu plano (o paralelo de Bagdade) e progridem para leste para alcançar o rio Tigre. Juliano acumula vitórias, mas o seu exército começa a acusar graves dificuldades de abastecimento. 

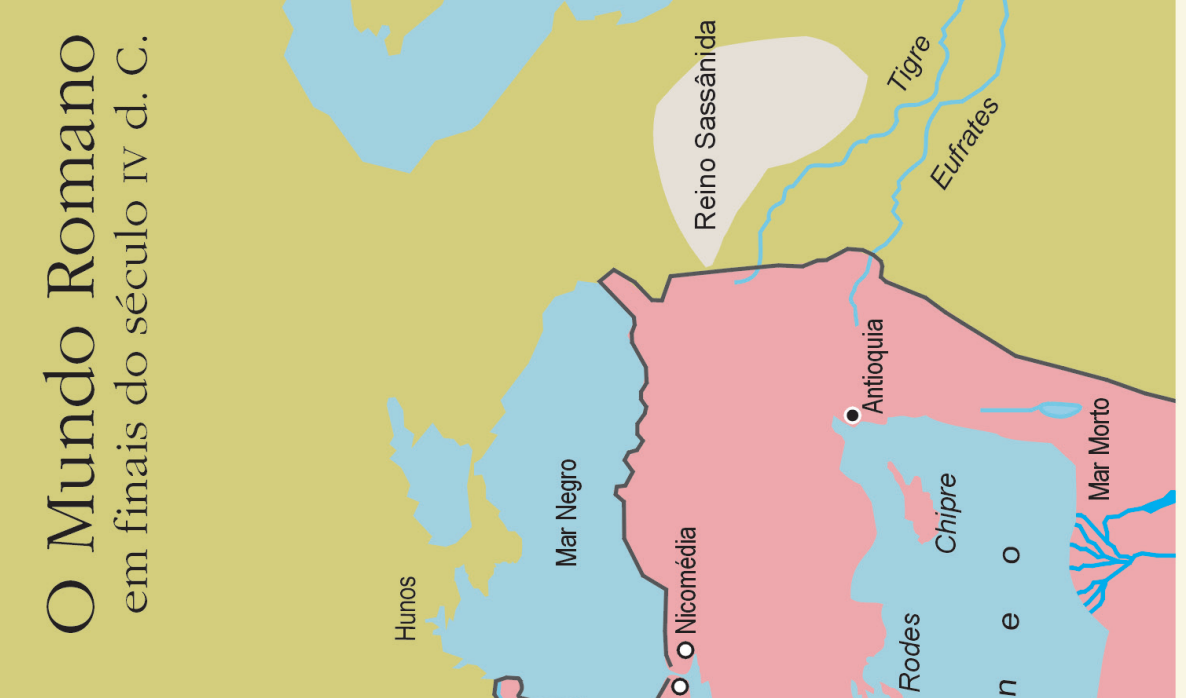

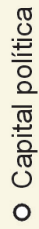
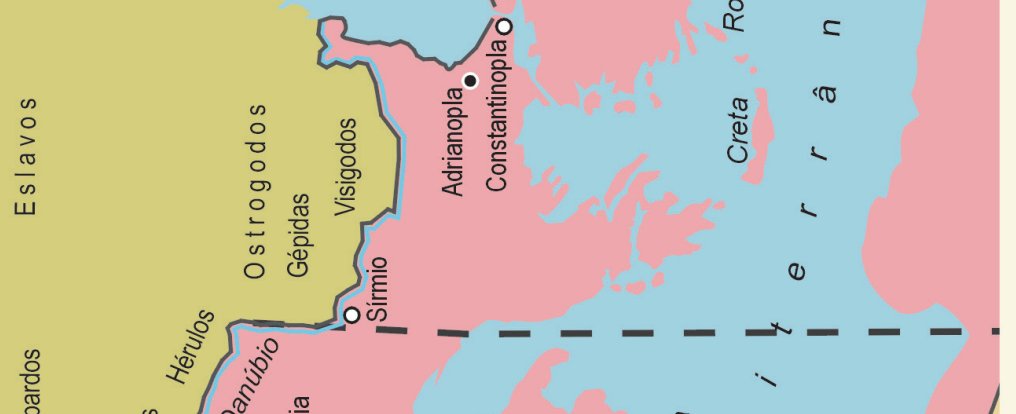

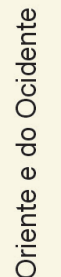

亭

善

鱼
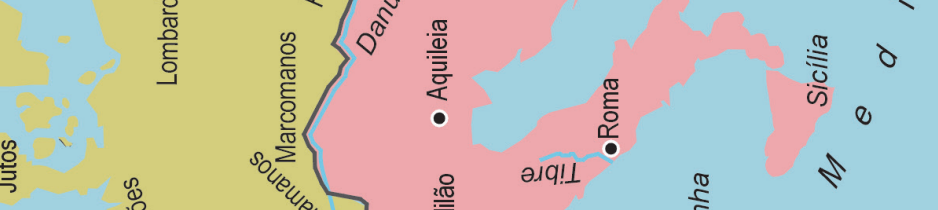
A resistência anímica afunda-se e o imperador acaba por morrer, ferido por um dardo num combate travado em junho de 363. Fim inglório para uma campanha que fez estremecer profundamente o império dos Persas.

Mais inglório ainda seria porque Joviano, o imperador escolhido pela guarda imperial para suceder a Juliano, decidiu de imediato retirar as tropas romanas de muitos dos territórios conquistados na Mesopotâmia, na Arménia e na Ibéria caucasiana, assentindo numa paz que parece ter surpreendido os próprios Persas. Para agravar a situação, Joviano morreria logo em 364, levando os oficiais da guarda a escolher um cristão moderado, Valentiniano I (364-375), como seu sucessor. Quando lhe pediram que nomeasse um assessor, o novo líder escolheu o seu próprio irmão, Valente, o protagonista da batalha de Adrianopla (378).

\section{As trombetas da guerra}

Amiano Marcelino escreve que, em 364, "todo o mundo romano escutava as trombetas que chamavam para a guerra". De facto, novos e velhos inimigos atacavam o Império Romano em várias frentes: os Burgúndios atingiam o Reno; os Hunos (surgidos em 360) empurravam os Godos; os Alamanos continuavam a ameaçar a Gália e a Récia (atual sul da Alemanha e Áustria); os Godos cobiçavam as riquezas da Panónia (atual Hungria) e a Trácia (atual Bulgária); e os Persas, não se contentando com a 'generosidade' de Joviano, aspiravam a controlar toda a Arménia. Mesmo nas regiões menos problemáticas, a agitação estava agora presente. Única nota positiva: o relativo sossego dos Francos, acalmados talvez pelas terras e pelos postos no exército que os Romanos lhes haviam confiado...

No verão de 364, Valentiniano I e Valente partilharam tudo entre si: territórios, capitais, comando de tropas e problemas militares. Valentiniano I assumiu a guarda do Ocidente e o seu irmão Valente a do Oriente. Para aumentar o número de unidades militares, acelerou-se o já referido processo de 'miniaturização' das legiões. Mesmo assim, a situação depressa se complicou, graças a revoltas e a tentativas de golpe contra Valente. Logo em 367, a doença de Valentiniano I levou-o a associar ao trono o seu jovem 
filho Graciano (367-383). Entre 364 e 375, Valentiniano I fez um grande esforço para controlar a situação em toda a frente ocidental. Porém, em 375, morreu de apoplexia e a parte ocidental do Império foi dividida pelos seus dois filhos, Graciano (que seria educado pelo grande escritor Ausónio) e Valentiniano II.

Pelo seu lado, no Oriente, Valente não enfrentava dificuldades menores. Os Godos constituíam a principal ameaça, mas havia também os Persas e o banditismo. Os Godos tinham, durante muito tempo, respeitado o tratado firmado com Constantino I, mas depois mudaram de política e começaram a lançar raides para se instalarem no interior do Império Romano, atraídos pelas riquezas e como forma de proteção contra os Hunos e os outros bárbaros que iam chegando. Em 364, a fome incentivou as investidas godas sobre o território romano, multiplicando-se as operações de pilhagem na Trácia, ao que Valente ia respondendo como podia. Mais a leste, os Persas tinham invadido a Arménia e a Ibéria, instalando aí monarcas que lhes eram favoráveis; em 375-376, esgotada a via diplomática, as hostilidades recomeçaram em força. Más notícias para Valente, no preciso momento em que os Hunos tinham obrigado os Alanos a tornarem-se seus aliados, uns e outros ameaçando agora os Godos na margem esquerda do baixo Danúbio...

Os Hunos venceram os Ostrogodos (na altura: os Greutungos) e instalaram-se na Dácia, na margem norte do Danúbio. Acossados, em 376 os Godos quiseram passar para sul do rio e, sob o comando de um dos seus reis, um Visigodo (isto é, um Tervingo) chamado Fritigerno, formaram uma ampla coligação, instalando-se na Mésia (nas atuais Bósnia-Sérvia-Bulgária). Valente pouco podia fazer e parece ter aceitado este movimento (segundo alguns autores, contra a deposição das armas e a promessa de conversão desses cristãos arianos ao catolicismo, e também com a expetativa da incorporação de muitos deles no exército de Roma). Mas, ao mesmo tempo, o imperador romano fazia jogo duplo, preparando uma guerra contra os Godos.

Convém dizer que, ao cruzarem o limes do Império Romano, os Godos de Fritigerno não inovavam - outros povos bárbaros já tinham acalentado o mesmo projeto: as chamadas "grandes invasões" foram um processo longo e demorado! Só que, desta vez, os bárbaros eram em grande número. E mais: em 376-377, o movimento dos Godos era irreversível, embora ninguém o 
soubesse na altura. Instalados na Trácia, perto de Marcianópolis, os Godos foram vítimas da hostilidade e cupidez dos oficiais romanos, que faziam os possíveis para que o abastecimento em víveres não chegasse até eles, já que achavam que eram inimigos. Segundo consta, esses oficiais chegavam a exigir aos Godos que lhes entregassem crianças como escravos, em troca do fornecimento de carne de cão.

Assim, os Godos partiram para a guerra, pilhando as províncias romanas da Trácia, da Panónia, da Macedónia e da Tessália (atual Grécia). A reação de Valente parece ter-se dado em dois tempos: por um lado, pediu ao seu "mestre da cavalaria" que comandava o exército do Oriente que fizesse a paz com os Persas, de modo a ficar descansado no que a esta frente de luta dizia respeito; por outro, reorganizou as suas forças na Trácia. Daqui até Adrianopla cumprir-se-iam ainda mais algumas etapas.

\section{A caminho de Adrianopla}

Primeiro, Lupicino, um oficial de Valente, tentou assassinar Fritigerno e um outro líder visigodo (Alavivo); mas a operação correu mal: Fritigerno escapou, os súbditos revoltaram-se e Lupicino acabou morto, com muitos homens incluindo vários tribunos. Sob as ordens de Fritigerno, os Godos que estavam perto de Adrianopla assaltaram então uma oficina de armas romana e devastaram, mais uma vez, a Trácia. Na sequência disto, Valente enviou reforços para a província ocupada, sob as ordens de dois oficiais superiores. A seguir, o imperador reagrupou as tropas (legiões da Arménia, auxiliares da Panónia e da Transalpina comandados por Frigérido, coortes da Gália) e confiou-as a Ricomero, o seu "conde dos domésticos" (um corpo da guarda pessoal do imperador). Após alguns combates menores, Ricomero foi enviado à Gália com o objetivo de reunir reforços; mas, tal como no tempo de Constâncio II, os soldados dessa província não tinham entusiasmo em combater longe da sua pátria e registaram-se muitas deserções.

Segundo a narrativa de Zósimo, o imperador Valente terá então ordenado a um seu "mestre da cavalaria", Saturnino, que bloqueasse as principais passagens, instalando aí unidades de Sarracenos federados. A seguir, já na 
primavera de 378, Valente pediu também a um seu "mestre da infantaria", Sebastião, que importunasse, por meio de ataques diversos, os recém-chegados Godos. Por fim, Valente abandonou Antioquia e rumou a Constantinopla (a atual Istambul).

A chegada do imperador do Oriente a Constantinopla prenunciava uma grande batalha. E Valente estava confiante, até porque Sebastião conseguira surpreender os Godos carregados de despojos e tinha-os massacrado. Mesmo assim, antecipando o combate, Valente solicitou a ajuda do sobrinho Graciano, ao mesmo tempo que o rival Fritigerno reagrupava as suas forças.

Em princípios de agosto, o imperador Valente deixou Constantinopla e marchou para a importante cidade de Adrianopla (atual Edirne, na Turquia), onde deveria esperar a chegada das tropas de reforço que lhe seriam trazidas pelo sobrinho, o imperador do Ocidente. Para o efeito, Valente instalou um acampamento fortificado no exterior da cidade; ali recebeu, contudo, a notícia de que os Visigodos só dispunham de 10000 homens armados. Esta informação não correspondia à verdade, tanto mais que o exército visigodo estava reforçado por grupos de Ostrogodos, de Hunos e de Alanos e por escravos em fuga. Mal informado, e suspeitando de que os inimigos manobravam entre si e Constantinopla (esgueirando-se na direção de Nice, 15 milhas a sudeste, na esperança de cortarem as linhas de abastecimento romanas), Valente começou então a acalentar o plano de precipitar o combate antes da chegada do imperador do Ocidente, saboreando antecipadamente a glória pessoal de uma vitória...

\section{O cenário da batalha}

De acordo com Rodríguez González, que para o efeito se baseia nos estudos de MacDowall, o exército godo de Fritigerno poderia incluir os seguintes contingentes:

a) 1000 cavaleiros pesados visigodos (pertencentes ao próprio séquito do líder);

b) duas unidades de infantaria pesada visigoda (cada qual com 300 a 400 homens), desertoras do exército romano; 

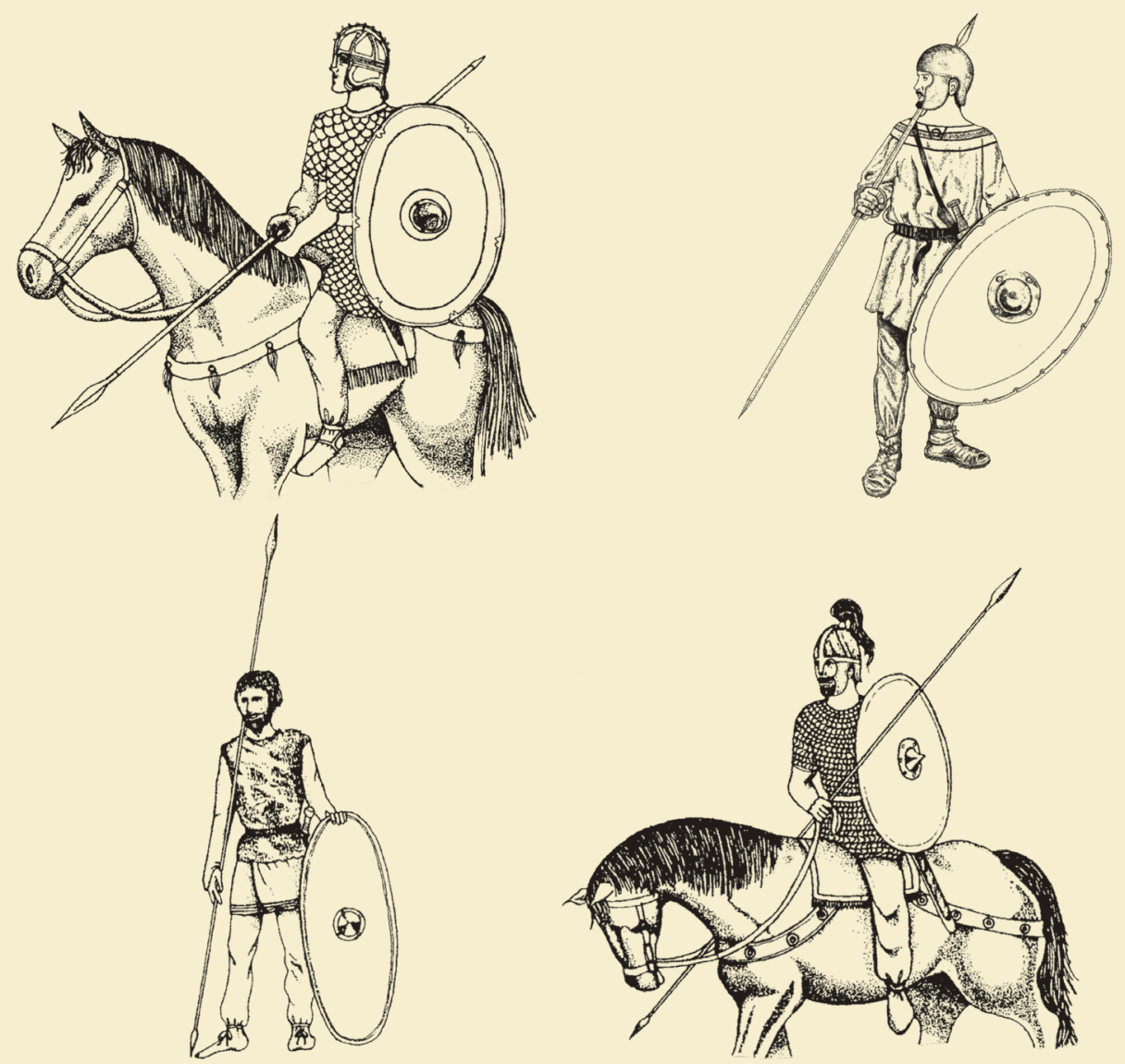

Em cima à esquerda

Cavaleiro romano do Baixo Império (séc. IV) equipado com capacete, loriga de escamas, lança e escudo oval.

(C) Drawn by Schelay Richardson after Warry 1980. "From The Fall of the Roman Empire: The Military Explanation", by Arther Ferril, Thames and Hudson Ltd., London (p. 49).

\section{Em cima à direita}

Peão romano do séc. IV, possivelmente de origem bárbara, devido à barba .

(C) Drawn by Schelay Richardson after Connolly. "From The Fall of the Roman Empire: The Military Explanation", by Arther Ferril, Thames and Hudson Ltd., London (p. 48).

Em baixo à esquerda

Guerreiro bárbaro: peão visigodo dos inícios do séc. V.

(C) Drawn by Schelay Richardson after Warry 1980. "From The Fall of the Roman Empire: The Military Explanation”, by Arther Ferril, Thames and Hudson Ltd., London (p. 144)

Em baixo à direita

Guerreiro bárbaro: cavaleiro ostrogodo do séc. IV (provavelmente um líder).

(C) Drawn by Schelay Richardson after Warry 1980. "From The Fall of the Roman Empire: The Military Explanation", by Arther Ferril, Thames and Hudson Ltd., London (p. 144). 
c) entre 6000 e 8000 lanceiros, uma mistura de Visigodos, de Romanos e de soldados com outras procedências (talvez enquadrados em unidades de 500 a 1000 homens);

d) 1000 a 2000 arqueiros a pé, cuja função consistiria talvez em apoiar os lanceiros desde a sua retaguarda;

e) cerca de 1000 cavaleiros pesados dos Ostrogodos (no seio dos quais haveria também alguns Alanos e, eventualmente, alguns Hunos), pertencentes à guarda pessoal dos chefes com essas origens;

f) mais outros 2000 a 3000 cavaleiros pesados ostrogodos (talvez inseridos em unidades de 500 homens);

g) entre 1000 e 2000 arqueiros alanos a cavalo;

h) entre 500 e 1000 arqueiros ostrogodos a pé;

i) e, finalmente, uns 500 arqueiros hunos a cavalo.

Ao todo, entre 13600 e 19300 combatentes, metade dos quais montados (embora convenha notar que muitos destes guerreiros podiam combater também a pé).

No dia 9 de agosto de 378, logo ao amanhecer, o exército romano abandonou o acampamento junto a Adrianopla e iniciou a sua marcha de oito milhas (c. $13 \mathrm{~km}$ ) para norte, em direção ao acampamento dos Godos (perto da atual povoação de Demirhanli), caminhando a maior parte do tempo sob um calor sufocante.

As fontes clássicas atribuem 60000 homens ao imperador Valente, mas é hoje seguro que o número real seria muito inferior. MacDowall fala em apenas 15000 soldados, enquanto outros autores pensam que esse número não ultrapassaria os 10 000. Aceitando a conjetura de MacDowall, que nos parece mais razoável, haveria:

a) 1000 cavaleiros de elite (equites palatini);

b) 1500 cavaleiros do "exército de manobra" (equites comitatenses);

c) 11000 infantes de elite (entre legiões palatinae e auxilia palatina);

d) rodeando o imperador Valente, 1500 homens enquadrados em três batalhões das Scholae Palatinae (a nova guarda imperial). 
Todos os homens eram soldados bem instruídos, capazes de alcançar o campo de batalha em boa ordem e enquadrados por oficiais experientes, em unidades com muitos veteranos, na sua maioria procedentes - segundo Rodríguez González - dos exércitos das dioceses da Trácia e do Oriente. Este último autor admite também que pudessem estar presentes as duas legiões fronteiriças que guardavam a província da Mésia desde há séculos (a Legio I Italica e a Legio XI Claudia).

Antes da marcha, reunira-se o conselho de guerra romano para decidir se se abririam as hostilidades de imediato ou após a chegada das tropas de Graciano. Nesta reunião, Valente e alguns dos oficiais (por convicção ou por lisonja ao imperador) contrariaram a opinião dos mais prudentes (como o mestre da cavalaria, Vítor) e defenderam a tese de que o imperador conseguiria, com o seu talento, obter a vitória, não precisando por isso de dividir os louros do triunfo com ninguém. Para mais, o imperador já contava também com o pequeno contingente militar que Ricomero pudera reunir no Ocidente. Ora, logo nesse momento, Valente cometeu um erro gravíssimo, ao subestimar os efeitos da fadiga, da fome e da sede sobre os soldados romanos. Ainda por cima, a coluna de marcha romana, já disposta em função da batalha que se avizinhava (possivelmente com a cavalaria da ala direita na frente, a infantaria no meio e a cavalaria da ala esquerda na retaguarda), era muito extensa e uma boa parte dela estava ainda longe de ter alcançado o acampamento dos Godos.

Os dois exércitos avistaram-se cerca das 14 horas, quando os Romanos ainda não haviam comido. O imperador Valente formou as tropas que já tinham chegado em várias linhas, a partir da direita (como era costume entre os Romanos), com a cavalaria nas alas e a infantaria no centro, para além de um corpo de elite mais recuado, que ficaria de reserva.

Quanto aos Visigodos, dispostos no cimo de uma colina, ordenaram em círculo as suas carroças de transporte (formando o tradicional carrago), em que viajavam as suas famílias e os respetivos pertences. Segundo MacDowall, estamos a falar de 2000 a 5000 carroças, albergando um total de 30000 pessoas (incluindo mulheres, crianças e outros não combatentes), dispostas num círculo com dois ou três quilómetros de diâmetro! 
Fritigerno mandou então chamar a sua cavalaria, incluindo a dos Ostrogodos e dos Alanos (sob o comando de Alateu e de Safrax), que não tinha sido detetada nas missões de observação dos batedores romanos porque na altura se encontrava longe, em busca de mantimentos e de forragens. Fritigerno ordenou-lhe que regressasse de imediato e que se reunisse ao resto do exército bárbaro. Enquanto isso não acontecia, o líder dos Visigodos, procurando ganhar tempo, enviou um mensageiro (um clérigo cristão) ao arraial romano com o pretexto de negociar a paz, reivindicando o abandono da Trácia pelos Romanos. Valente, porém, porventura desejoso de dar oportunidade a que todo o seu exército alcançasse o campo de batalha, terá mandado dizer a Fritigerno que, se queria entabular negociações a sério, deveria enviar como emissários gente de mais nobre condição.

O chefe visigodo acedeu e iniciaram-se os preparativos para negociações de alto nível, acompanhadas pela entrega de reféns. Neste contexto, e depois de o tribuno e alto oficial da corte Equício (um parente do imperador) se ter escusado a fazê-lo (segundo Marcelino, porque escapara como prisioneiro de guerra e receava agora a ira dos Godos), o próprio Ricomero foi enviado ao acampamento inimigo para parlamentar.

Ao mesmo tempo, segundo relata ainda Amiano Marcelino, os Visigodos aproveitaram o impasse para atear fogo às matas dos arredores do campo de batalha, tirando partido do vento para provocar fumo e para aumentar o calor e a confusão entre os Romanos, cujos soldados estavam então a ocupar as suas posições de combate sem comer nem beber e suando a jorros debaixo dos seus uniformes...

\section{O combate}

Nesse momento, duas unidades avançadas da cavalaria romana, provavelmente dispostas na ala direita e formadas por arqueiros montados e por membros dos scutarii da guarda imperial - tropa essa sob o comando de Cássio e do georgiano Bacúrio e a quem tinha sido dada ordem para fustigar o adversário antes do começo da batalha -, cometeu o erro de 
carregar em força sobre o carrago dos Visigodos. Ou seja, como por vezes sucedia quando dois exércitos ficavam frente a frente demasiado tempo sem combater, aquilo que devia fazer parte de uma simples escaramuça preliminar acabou por dar início à batalha, isto apesar de a cavalaria da ala esquerda romana não estar ainda completamente formada! Valente cometia assim mais dois erros, ao mostrar não ser capaz de conduzir as suas tropas todas em sincronia e ao não conseguir preservar a disciplina no seio do seu exército.

Ricomero, ainda a caminho, foi mandado regressar. Um rastilho de violência sacudiu as linhas dos dois adversários e a batalha principiou assim, em condições de completo desequilíbrio para os Romanos. A escassa potência da carga inicial dos cavaleiros e arqueiros montados de Valente fez com que ela fosse facilmente rechaçada pelos Godos. Marcelino diz que "a sua retirada foi tão covarde quanto o seu avanço tinha sido temerário, um começo de batalha extremamente desfavorável". Os Romanos, que se haviam precipitado na ânsia de alcançar o carrago visigodo, foram assim empurrados em desordem contra os seus próprios companheiros do flanco direito, que aguardavam na linha de batalha o início do combate.

Nessa altura, e embora as fontes de que dispomos não sejam explícitas a este respeito, é possível que o segmento da cavalaria romana que já estava disposto em formação de batalha no flanco esquerdo tenha sido mandado avançar, com a intenção de equilibrar a contenda e de dispersar a atenção dos Visigodos que castigavam o flanco direito romano. Ao que parece, esse ataque (ignoramos quem o comandaria, mas é provável que reunisse cavalaria pesada e arqueiros a cavalo) teve, de início, algum sucesso, com a tropa montada da asa esquerda romana a conseguir chegar até ao parque de carroças inimigo. Segundo Marcelino dá a entender, tê-lo-ia mesmo tomado caso tivesse recebido algum apoio de outras forças montadas. Todavia, não só isso não sucedeu (nem podia suceder devido ao atraso do resto da ala esquerda romana, que fechava a coluna de marcha e por isso não alcançara ainda o campo de batalha), como se verificou então algo que decidiria a jornada.

É que, nesse preciso momento, a cavalaria ostrogoda (e também alana e porventura huna), que os batedores romanos não haviam identificado e que 


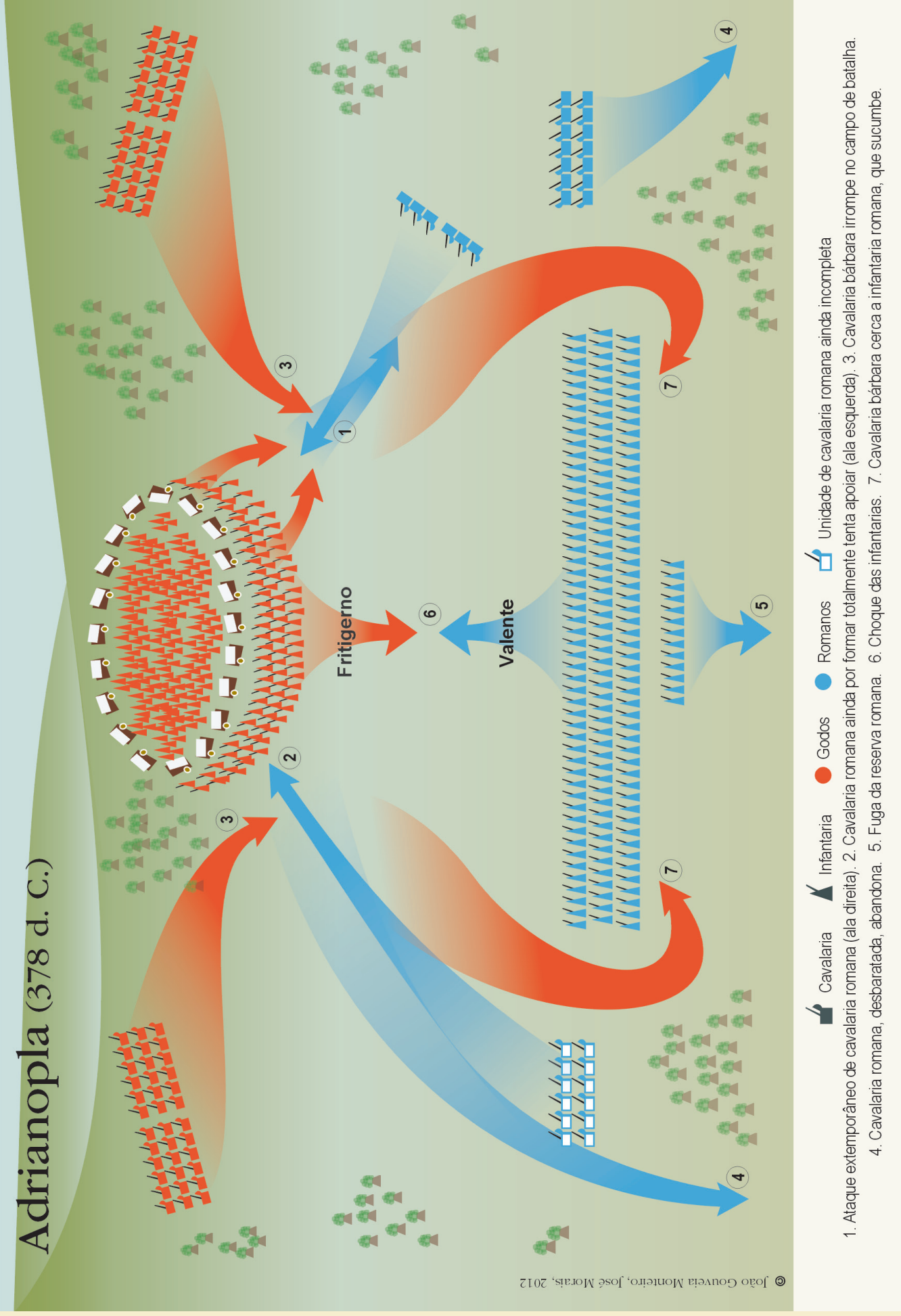


Fritigerno tinha mandado chamar a toda a pressa, chegou ao acampamento dos bárbaros! Sob o comando de Alateu e de Safrax, vindas do cimo da colina "como um raio dos céus" (as palavras são de Marcelino), estas forças (que lutavam à maneira greco-romana, com lanças curtas de arremesso e espadas, e não ao estilo dos nómadas das estepes, que confiavam sobretudo em arqueiros montados) carregaram de imediato sobre a cavalaria dos Romanos. Estes, surpreendidos pelo ataque, resistiram durante algum tempo, mas, "sob a pressão dos números, cederam e sucumbiram como um muro que rebenta" (Marcelino). Ao que parece, a debandada da cavalaria romana arrastaria na fuga o corpo de infantaria pesada dos Batavos que Valente dispusera em posição mais recuada, como reserva. Ou seja, a infantaria romana ficava, a partir de então, entregue a si própria...

Neste momento, Fritigerno mandou avançar a infantaria, que até essa altura se tinha limitado a preservar a sua posição defensiva na parte mais alta da encosta. Aí, a infantaria pesada de Valente (a maior parte dela armada de cota de malha, de escudo redondo ou oval, de lança e de espada bem mais comprida do que o gládio típico das épocas precedentes) avançou também, e deu-se o choque entre as duas forças. Os legionários romanos e as forças de pé auxiliares que os acompanhavam estavam bem treinados e prometiam dar boa réplica perante uma infantaria bárbara, que já tinham enfrentado e vencido outras vezes. Não devemos, no entanto, esquecer-nos de que, nas alas, a cavalaria ostrogoda-alana-huna estava agora liberta de opositores e à vontade para envolver a infantaria romana. E foi precisamente isso que aconteceu.

A situação parece ter sido especialmente dramática para os Romanos na ala esquerda, onde as fragilidades da cavalaria tinham sido maiores e onde mais cedo se abrira, por isso, uma brecha por onde penetraram em massa os Godos; nessa zona do terreno, depressa a infantaria romana se viu comprimida. Como explica Amiano Marcelino, "isto deixou a infantaria desprotegida e os soldados tão apertados uns contra os outros que dificilmente algum deles conseguia brandir a sua espada ou recuar o seu braço depois de já o ter esticado"! Ao mesmo tempo, a escassa visibilidade agravava sobremaneira as condições da luta, tanto mais que os numerosos arqueiros a pé godos disparavam em massa sobre a infantaria romana: "A poeira formava 
nuvens tais que escondiam o céu, que ressoava com os gritos medonhos. Por conseguinte, era impossível avistar os mísseis do inimigo enquanto estes ainda vinham pelo ar e esquivar-se deles; todos encontravam o seu alvo e espalhavam a morte por todo o lado".

Nestas condições, a resistência da experiente linha de infantaria pesada romana podia ser heroica, mas era impossível ser bem-sucedida, envolvida que estava pelos inimigos: "Os bárbaros carregavam em colunas imensas, pisando cavalos e homens e comprimindo de tal modo as nossas fileiras que uma retirada organizada se tornava impossível. Os nossos homens estavam demasiado apertados uns contra os outros para que pudessem ter alguma esperança de escapar. Por isso, decidiram morrer como heróis, enfrentando os golpes dos inimigos e acometendo os atacantes" (A. Marcelino).

Tudo indica que o combate se prolongou ainda durante bastante tempo. Em parte, isso deve ter ficado a dever-se à resistência feroz oferecida por duas legiões de elite sob o comando direto do imperador Valente: os lanciarii (lanceiros) e os mattiarii (os lanceiros dos auxilia palatina), ao todo uns 1500 homens (pois as legiões no séc. IV eram já muito mais pequenas). "De ambos os lados, capacetes e peitorais eram despedaçados pelos golpes dos machados de guerra. Podia ver-se um bárbaro com coração de leão a quem tinham sido cortados os tendões ou o seu braço direito, ou que tinha sido ferido de lado, rangendo os dentes cerrados e lançando olhares desafiadores no momento da sua agonia. Nesta matança recíproca, eram derrubados tantos que o campo estava coberto com os corpos dos mortos, ao mesmo tempo que os gemidos dos que estavam a morrer e os dos gravemente feridos enchiam todos aqueles que os ouviam de um medo horroroso" (A. Marcelino).

Esse momento seria decerto para Valente a altura adequada para fazer entrar em ação as suas forças de reserva, compostas sobretudo pelas unidades de infantaria pesada dos Batavos (um belicoso povo germânico, estabelecido no baixo Reno). No entanto, quando o mestre da cavalaria, Vítor, as procurou, percebeu que também elas já tinham abandonado o campo de batalha... O imperador via-se, portanto, privado de um plano alternativo de combate. Como narra Marcelino: "Neste ambiente de confusão total, a infantaria, esgotada pelo esforço e pelo perigo, não tinha força ou 
réstia de discernimento para armar um plano. A maioria tinha visto as suas lanças ficarem feitas em pedaços durante os choques constantes, pelo que decidiram sacar das suas espadas e lançar-se no meio da densa massa de inimigos, sem olhar à sua salvação e conscientes de que não havia esperança de poderem escapar. O terreno estava tão ensopado de sangue que eles escorregavam e caíam, mas faziam das tripas coração para vender caro as suas vidas e enfrentavam os adversários com tanta determinação que alguns chegavam a morrer vítimas das suas próprias armas. No final, quando todo o campo era uma poça escura de sangue e eles já nada podiam ver a não ser pilhas de mortos para onde quer que dirigissem o olhar, calcavam sem escrúpulos os corpos sem vida".

Os Godos acabaram por cercar quase por completo os Romanos, incluindo os setores que mais e melhor tinham resistido. Já não havia condições para prolongar a batalha e nem havia já esperança de qualquer auxílio. "O Sol, que brilhava alto lá no céu (estava a deslocar-se para a casa da Virgem depois de ter atravessado Leão), queimava os Romanos, que estavam enfraquecidos pela fome, ressequidos pela sede e esmagados pelo peso das suas armaduras. Por fim, a nossa linha cedeu sob a pressão insuportável dos bárbaros e, como último recurso, os nossos homens deram aos calcanhares num 'salve-se quem puder' generalizado" (A. Marcelino).

Os Godos atacaram então os sobreviventes e os fugitivos com flechas e, depois, desataram a persegui-los e a matá-los pelas costas, com espadas ou com lanças. Tanto Ricomero como Vítor e Saturnino conseguiram escapar (talvez por terem abandonado o terreno logo que se aperceberam da fuga dos Batavos), mas o imperador Valente perdeu a vida nesta batalha, existindo duas versões sobre a sua morte: segundo Marcelino, terá sido atravessado por uma flecha; segundo Paulo Orósio (c. 390-c. 431, presbítero bracarense e historiador, discípulo de Santo Agostinho e autor da célebre Historiarum libri VII adversus paganos), foi primeiro ferido e depois levado por uma escolta sua até uma casa nas redondezas, à qual os Godos poriam fogo sem saber quem se encontrava lá dentro, resistindo.

Como quer que seja, certo é que os Romanos sofreram baixas pesadíssimas: cerca de dois terços do seu exército (ou seja, c. 10000 homens), entre mortos, feridos e prisioneiros. No extenso rol de baixas, para além 
do imperador figuravam os nomes do magister peditum Sebastião e de mais de 30 tribunos. O magister equitum Vítor, acompanhado na sua fuga por um número reduzido de cavaleiros, foi ao encontro de Graciano (que se encontrava já próximo de Adrianopla), a quem daria a nova do desastre.

As últimas palavras de Amiano Marcelino, contemporâneo da tragédia, não deixam dúvidas acerca da forma brutal como a derrota foi sentida pelos Romanos: "Nenhuma batalha da nossa história, exceto Canas, constituiu um tamanho desastre, apesar de por mais de uma vez os Romanos terem sido os joguetes da Fortuna e terem sofrido reveses temporários e de muitas lutas desastrosas estarem registadas com mágoa nas elegias da Grécia”...

\section{Depois da batalha}

Como seria de esperar, os Godos tentaram explorar o mais possível o sucesso obtido na batalha de Adrianopla, cercando de imediato esta cidade, mas em vão. Depois, aliaram-se de novo aos Hunos e aos Alanos para devastar o que restava da Trácia e visaram mesmo Constantinopla, a capital do Império Romano do Oriente, mas foram rechaçados. Júlio, o mestre das milícias de além-Tauro (cadeia de montanhas da Ásia Menor), reorganizou a defesa das províncias orientais e, com isso, salvou-as. A derrota romana provocou também um recomeço das hostilidades com os Persas, levando ao abandono definitivo da Arménia e da Ibéria do Oriente. No entanto, c. 387, acabaria por ser assinada uma paz duradoura desse lado do mundo.

Talvez a batalha de Adrianopla não tenha a amplitude épica que os relatos de Marcelino lhe conferiram. No entanto, ela provocou a morte do imperador e a abertura definitiva do Império Romano aos Godos. Nesse sentido, talvez Edward Gibbon tenha tido razão quando afirmou que, precedidas pela instalação definitiva de pequenos grupos de bárbaros, as "grandes invasões" só começaram verdadeiramente a partir de 378. Para além disso, a derrota de Adrianopla marcaria as mentalidades coletivas e teve consequências importantes nos domínios da tática, do recrutamento e da atitude (mais ambígua) dos Romanos perante os seus inimigos. 
Durante o reinado de Teodósio I (379-395), que assumiu o poder a Oriente na ressaca do desastre de Adrianopla, as revoltas e as tentativas de golpe de Estado diminuíram, mas não desapareceram. As mais célebres são a de Magno Máximo, em 383; e a de Eugénio: proclamado em Lyon, na sequência do suicídio ou assassinato de Valentiniano II, seria derrotado por Teodósio I na batalha do rio Frígido, em 394. Também certos príncipes africanos aspiravam à autonomia, enquanto a situação se agravava paulatinamente na Bretanha e no Reno e o banditismo crescia entre os próprios Romanos. Só a frente oriental apresentava sinais animadores, com Teodósio a conseguir um bom acordo com os Persas e até uma aliança com eles contra os temíveis Hunos, que em 395 transpuseram o Cáucaso e devastaram a Capadócia (na atual Turquia), a Cilícia (atual Turquia, próximo da fronteira com a Síria) e o leste da Síria.

No final do séc. IV, os Hunos assumiram, portanto, o lugar dos Persas em matéria de ameaça militar na frente leste. Mas havia também o problema godo, que se agravara significativamente após Adrianopla: a partir de então, já não se tratava de raides ou de invasões pontuais do Império Romano; eles simplesmente migravam para o interior do Império, sem que os Romanos pensassem sequer em expulsá-los. Cristianizados, os Godos iam contando também com alguma proteção dos bispos.

Assim sendo, as novas leis sobre a organização do exército e as novas unidades militares criadas por Teodósio refletem já um dado adquirido por todos, e que a derrota de Valente em Adrianopla tornara irreversível: a submersão do mundo romano por uma vasta gama de povos bárbaros, parte dos quais ia obtendo o estatuto de "federados". Outros, porém, evoluíam de forma diferente. Por exemplo, Godos, Hunos e Alanos tomaram a Panónia e devastaram a Ilíria, enquanto a Gália ficava quase em ruínas.

A morte de Teodósio I formalizaria a divisão do Império em dois: o Ocidente, para Honório, e o Oriente para o outro filho, Arcádio. No primeiro caso, porém, o verdadeiro poder ficava nas mãos de um homem dos Vândalos, de nome Estilicão, enquanto, no caso de Arcádio, o poder passou das mãos do eunuco Eutrópio para as do godo Gaina. Entre 395 e 400, os combates chegam a todas as frentes. Destacaremos apenas, no Oriente, a marcha de Alarico (um visigodo) sobre Constantinopla, seguida da devastação da Grécia, da Macedónia e da Tessália, que Estilicão não conseguiu evitar. 
Em 397, um acordo permitiu aos Godos instalar-se no centro da Macedónia, enquanto Alarico recebia o título de "mestre das milícias" da região da Ilíria, e Fravita, seu compatriota, idêntico cargo para o Oriente. Alguns guerreiros dos Hunos foram integrados no exército imperial enquanto outros avançaram para os Balcãs, onde viriam a ser vencidos (em 409), desviando-se então para o Ocidente. O Império Romano do Oriente acabava de fazer uma escolha dramática: não podendo derrotar os seus inimigos, optou por desviá-los para a parte ocidental do Império!

Esta decisão apressaria o naufrágio do Império Romano do Ocidente. Dois eventos maiores assinalam o início do fim desse processo. Por um lado, na noite de 31 de dezembro de 406, uma coligação de Vândalos, Alanos e Suevos cruza a fronteira gelada do Reno, em direção a Mogúncia; são dezenas de milhares e, durante três anos, põem o Norte da Gália a ferro e fogo; a situação torna-se gravíssima, pois a fronteira acaba de ser rompida para sempre, já não sendo possível aos exércitos romanos rechaçar o inimigo e devolvê-lo às suas posições originais. Por outro lado, em 400, a vanguarda dos Godos alcança a Península Itálica, cercando Aquileia e Milão; Estilicão consegue repeli-los para a Ilíria, mas uma segunda vaga chegará entre 408 e 410, exigindo terras, títulos e dinheiro. Os 6000 homens do exército da Dalmácia (atual Croácia), uma elite de soldados enviada por Honório, são aniquilados por Alarico (de novo adversário dos Romanos); em 410, com o imperador escondido em Aquileia, Roma é tomada e saqueada pelos Godos durante três dias!

Após os fiascos de 406 e de 410, o exército romano do Ocidente estava vencido e já não poderia recompor-se; aos poucos, Roma foi abandonando as províncias à sua sorte. O Ocidente não podia mais defender-se, com os exércitos da Península Itálica, da Espanha, de África e mesmo da Gália a atingirem um nível formidável de incapacidade. Politicamente, criaram-se Estados em paralelo com o Estado romano e o que restava das suas unidades. Os soldados "romanos" já só o eram de nome. Durante quase sete décadas, sucede-se ainda um rol de imperadores menores, de que constam sobretudo Valentiniano III (425-455) e, claro, Rómulo Augústulo. Em 476, o rei dos Hérulos, Odoacro, provavelmente um homem de origem turco-mongol, confisca as insígnias imperiais que Rómulo detém e envia-as para Constantinopla; o Império Romano do Ocidente acabara, mesmo no plano 
das instituições. Exército e Estado romanos conheciam o mesmo destino: o Oriente romano torna-se o Oriente bizantino, enquanto o Ocidente romano cede o seu lugar ao Ocidente bárbaro. Razões económicas e, sobretudo, militares haviam tornado esta cisão inevitável.

Não vale a pena continuar a discutir se o Império morreu 'de morte natural' (por extremo envelhecimento) ou se foi 'assassinado' - a verdade reúne aspetos destas duas teses. A força e a capacidade bélica dos povos bárbaros (em muito maior número e com muito melhor conhecimento da arte da guerra do que nos sécs. I e II d. C.), as guerras civis e a egoísta decisão dos políticos orientais de empurrarem para poente o seu grave problema militar combinaram-se de forma explosiva com a crise económica, com o relaxamento da autoridade política, com o declínio do patriotismo romano (resultado também da evolução religiosa) e com a necessidade de reorganizar o exército em função da nova realidade demográfica e étnica. Como resume Yann Le Bohec, se existiu, "o assassino golpeou um corpo que já estava doente"...

Adrianopla foi decerto um marco relevantíssimo neste processo que sentenciou Roma. Por volta do ano 400, um alto funcionário do Império, homem culto e muito viajado, chamado Flávio Vegécio Renato, desgostoso com o rumo desfavorável que a guerra levava, decide compilar para o imperador um tratado onde reúne o essencial da sabedoria da arte da guerra acumulada pelos Romanos desde tempos muito remotos. Neste tratado, por onde passa a cada momento a nostalgia do tempo glorioso das grandes legiões, Vegécio escreveu o seguinte comentário (Livro III, cap. XI): "Deve também observar-se que não se deve obrigar um soldado fatigado por uma longa marcha, nem os cavalos cansados após uma corrida, a travar uma batalha campal. Aquele que vai combater perdeu muito das suas capacidades físicas com o esforço da marcha; o que fará aquele que já chega cansado à linha de batalha? Os antigos evitaram isto, mas, no nosso tempo e no passado recente, uma vez que os generais romanos não o acautelaram, eles, por falta de perícia, e para nada mais dizer, desgraçaram os seus exércitos. Com efeito, existe uma situação desigual quando entra em combate aquele que está cansado contra o que está folgado, o que transpira contra o que está fresco, o que veio a correr contra o que aguardou parado". 
Não parece abusivo reconhecer aqui os ecos da derrota de Valente em Adrianopla. Os Romanos tinham vontade de aprender com os seus próprios erros. E, desta batalha travada em 378 - o maior combate terrestre da história do Baixo Império romano, a pior derrota de Roma às mãos de um inimigo estrangeiro desde o séc. III e, provavelmente, a única batalha campal em que os bárbaros que invadiram e devastaram o Império alcançaram uma vitória esmagadora sobre os Romanos -, havia muitas lições para reter.

Antes de mais, a má condição anímica com que as tropas principiaram a batalha (fadiga, fome, sede). Em segundo lugar, o mau trabalho de observação prévia do inimigo. Por outro lado, o mau desempenho da cavalaria, que acusou evidente falta de treino e de disciplina e abriu prematuramente as hostilidades. E, finalmente, o comando desastrado de Valente, que, em claro excesso de confiança, não só não quis esperar pelo reforço de tropas que o seu sobrinho lhe asseguraria dentro de muito pouco tempo, como, depois, hesitou em relação ao abrir das hostilidades (entrando no jogo de Fritigerno) e, a seguir, se mostrou incapaz de controlar as suas tropas no terreno e de gerir as suas várias unidades (incluindo a tropa de reserva, um corpo fulcral na tradição militar romana).

O exército romano falhou e disso se aproveitou a vasta coligação goda. Adrianopla acabara por provar que a máquina imperial dos Césares já não era invencível em batalha campal. Os bárbaros agradeceram o ensinamento e redobraram em ousadia: 32 anos depois estavam às portas de Roma. O saque foi grande e o choque psicológico, esse, foi tremendo. Como observou Le Bohec, o evento foi sentido como "o fim do mundo, ou pelo menos como... o fim de um mundo".

\section{Fonte principal}

Amiano Marcelino, Histórias (Livro 31, esp. 12-13). Utilizámos a tradução inglesa de Walter Hamilton: Ammianus Marcellinus, The Later Roman Empire (AD 354-378), Penguin Books, 2004.

\section{Leituras recomendadas}

Adrian Goldsworthy, O fim do Império Romano. Lisboa, Esfera dos Livros, 2010.

Alexandru Madgearu, "Adrianople, Battle of (378)", in Clifford J. Rogers (Editor in Chief), The Oxford Encyclopedia of Medieval Warfare and Military Technology, vol. 1, Oxford, Oxford University Press, 2010 (p. 4). 
João Gouveia Monteiro e José Eduardo Braga, Vegécio, Compêndio da Arte Militar. Edição bilingue. Coimbra, Imprensa da Universidade de Coimbra, 2009.

Julio Rodríguez González, Diccionario de Batallas de la Historia de Roma (753 a. C.-476 d. C.). Madrid, Signifer, 2005 (pp. 213-214: "Hadrianopolis III").

Philippe Richardot, La fin de l'armée romaine (284-476). Paris, Economica, 2001.

Phyllis J. Jestice, "Adrianople, AD 378", in Battles of the Ancient World, 1285 BC-AD 451. From Kadesh to Catalunian Field. Londres, Amber Books, 2007 (pp. 198-205).

S. MacDowall, Adrianople AD 378. The Goths Crush Rome's Legions. Oxford, Osprey, 2001.

Yann Le Bohec, L'Armée Romaine sous le Bas-Empire. Paris, Picard, 2006. 


\section{CAPÍTULO 4}

\section{POITIERS (732): ALARME NA GÁLIA PERANTE OS MUÇULMANOS}

\section{Porquê Poitiers?}

A batalha de Poitiers foi travada em 732 (ou, hipótese mais remota, em 733) e opôs o exército de Carlos Martel, dux Francorum (chefe dos Francos), a um exército muçulmano liderado pelo governador árabe do al-Andalus, Abd al-Rahman ibn Abd Allah al-Ghafiqi.

Parece certo que a batalha se travou em outubro, havendo alguma dúvida acerca do seu dia exato. A hipótese mais provável é 25 de outubro, embora o combate deva ter prosseguido no dia seguinte. Não se conhece com rigor o local da batalha, mas é seguro que os dois exércitos se confrontaram algures entre Poitiers e Tours, no centro-oeste da Gália, provavelmente mais próximo da primeira do que da segunda destas cidades. Por vezes, este combate é referenciado por "batalha de Tours" ou de "Tours-Poitiers".

Esta batalha é considerada mais importante hoje em dia do que o foi na época em que teve lugar. Pelo menos, é isso que a escassez de informações nas fontes coevas disponíveis parece sugerir. Como quer que seja, trata-se de um dos combates em campo aberto mais representativos, do ponto de vista militar, e mais relevantes, do ponto de vista político, de toda a Europa durante a Alta Idade Média - designação que os historiadores ocidentais atribuem ao período situado entre 450 e 900 d. C. 


\section{Um problema de fontes}

Reconstituir a história europeia da Alta Idade Média, sobretudo os seus primeiros três séculos, é uma das tarefas mais exigentes a que o investigador pode meter ombros. As fontes são escassas e muito vagas, mesmo na datação dos eventos. Além disso, trata-se de fontes quase sempre ligadas à Igreja, redigidas num latim às vezes difícil de interpretar e muito parciais, sobretudo quando se trata de pôr em confronto cristãos e muçulmanos. Ao proceder à evocação de uma batalha, omitem quase sempre os pormenores que nós gostaríamos de conhecer e resvalam para descrições estilizadas, onde o modelo das narrativas bíblicas está muitas vezes presente.

Para conhecermos a história do Ocidente, e em especial a da Gália, na primeira fase da Alta Idade Média, dispomos sobretudo de quatro fontes: a Historia Francorum ("História dos Francos") redigida por Gregório, bispo de Tours em 573. É a fonte mais importante e minuciosa para o período da dinastia merovíngia (481-751), embora o seu relato termine um pouco antes do ano 600. A narrativa de Gregório de Tours é completada pela Crónica de Fredegário, um autor desconhecido do séc. viI; esta crónica deve ter sido escrita entre 630 e 660 e é uma fonte preciosa para conhecermos o reinado de Dagoberto I (623-639). Existe também o Liber historiae Francorum ("Livro da história dos Francos"), escrito por volta de 727; trata-se do nosso melhor guia para o período entre 643 e a década de 720, com a ascensão da família dos Pipínidas e os primeiros sucessos de Carlos Martel; o autor é um legitimista merovíngio que devia viver no Ocidente, perto de Soissons. Existe ainda a Continuação de Fredegário, da iniciativa de dois membros da família carolíngia (a dinastia que se seguiu à merovíngia: 751-987): Childebrando, dux da Burgúndia (m. após 751), meio-irmão de Carlos Martel e possível interveniente na batalha de Poitiers; e o seu filho Nibelungo (m. após 768). Esta crónica, apesar do seu nome, é independente da de Fredegário.

Sobre a batalha de Poitiers, concretamente, e para além da Continuação de Fredegário, a fonte mais pormenorizada é uma fonte hispânica coeva, intitulada Continuatio Hispana. Deve tratar-se da continuação de uma outra obra, possivelmente da Historia Gothorum ("História dos Godos"), do bispo Isidoro de Sevilha (560-636). Esta crónica deve ter sido escrita em Toledo 
ou em Córdova por volta do ano 754, pelo que também é conhecida por Crónica de 754. O seu relato cobre eventos situados entre 610 e 754, sendo uma das nossas melhores fontes para o conhecimento do período pós-visigótico na Hispânia e, portanto, para o estudo das conquistas muçulmanas na Península Ibérica e no Sul da Gália. O seu autor permanece anónimo, devendo ter sido um cristão moçárabe - nome dado aos cristãos ibéricos que viviam sob o jugo muçulmano, tendo adotado elementos da língua e da cultura árabes, mas sem que isso implicasse a sua conversão ao islão. É interessante registar que, na Crónica de 754, os Francos são designados por "nortistas" (septentrionales).

\section{A Europa nos inícios da Alta Idade Média}

A Alta Idade Média foi um período fulcral para a construção da Europa. Este tempo de génese e de fermentação de um mundo novo começou com a derrocada do Império Romano do Ocidente, a partir dos inícios do séc. V. Ou seja, a Alta Idade Média começou com as chamadas "invasões bárbaras”, que entregaram o domínio político e militar desse imenso espaço a que hoje chamamos Europa a um conjunto de povos com características civilizacionais profundamente diferentes das dos Romanos. Curiosamente, a Alta Idade Média terminaria também sob o signo das invasões, desta feita as dos Normandos, as dos Sarracenos e as dos Magiares, ocorridas entre finais do séc. VIII e finais do séc. IX. Entre uma data e outra, a "Idade Média" instalou-se na Europa, podendo dizer-se que a Gália, em especial as regiões situadas entre o rio Loire e o Reno, constituiu o coração desse novo mundo.

Em 410, os Visigodos chefiados por Alarico saquearam Roma, enquanto a pressão dos Hunos do temível Átila contribuiu fortemente para provocar a penetração dos povos bárbaros no Ocidente. Uma segunda vaga de invasores surgiu pouco depois, vinda do Norte. Reunia Francos e Alamanos, no continente, e Anglos e Saxões, nas Ilhas Britânicas. Mas foram muitos os povos que, ao longo do séc. v ou um pouco mais tarde, aproveitaram a derrocada do Império Romano do Ocidente para circularem livremente pela sua metade poente. Recordemos os mais famosos: 
- os Godos: vindos da Escandinávia (ou, segundo alguns autores recentes, do Sul da Alemanha), pressionaram a região fronteiriça do Danúbio, divididos em Ostrogodos e Visigodos. Cerca de 370, foram afetados pela chegada dos Hunos, tendo-se dirigido para oeste e arrastado consigo outros povos. Depois de saquearem Roma, acabaram por se instalar no sudoeste da Gália e na Península Ibérica (caso dos Visigodos) e na Itália (os Ostrogodos);

- os Vândalos, um povo que veio do Norte e que, depois de cruzar o Reno, atravessou a Andaluzia e chegou ao Norte de África, onde se fixou. Aos Vândalos se deve o saque de Roma em 455;

- os Alamanos, designação que reúne diversos povos (all man), que estacionaram nas proximidades do rio Main (Frankfurt);

- os Suevos, um povo de grande capacidade guerreira e que, sendo próximos dos Alamanos, se fixaram na Europa Central, mas foram depois arrastados para ocidente pelos Vândalos e acabaram por se estabelecer no noroeste da Península Ibérica;

- os Burgúndios, que vieram da Escandinávia e se instalaram na Renânia, de onde foram desalojados por Flávio Écio, o representante do imperador romano na Gália em meados do séc. v, e pelos Hunos. Nessa época, o seu território estendia-se pelo centro-sul da Gália;

- os Francos, um povo que absorveu muitos outros, como os Sicambros, os Chamaves, os Bructeros e os Chatos, tendo formado dois grupos principais: os Sálios, instalados na foz do Reno, e os Renanos ou Ripuários, estabelecidos nas margens do Reno, entre Bona e Colónia;

- os Anglos, os Jutos e os Saxões, todos eles povos germânicos que se instalaram no norte da atual Alemanha ou na Dinamarca, mas que realizaram incursões pela costa da Bretanha romana (a atual Inglaterra), onde se fixaram a partir do séc. V. Alguns dos Saxões estabeleceram-se nas costas da Gália, até à foz do rio Loire;

- os Pictos e os Escotos, povos celtas que ficaram famosos pelos seus raides e pilhagens. Os Escotos, vindos da Irlanda, atacaram a costa oeste da Escócia e fundaram aí um reino (a atual Escócia);

- os Lombardos, cuja migração em direção à Itália se verificou mais tarde, sobretudo nos sécs. VI e VII, chegando a ameaçar o papado. 
Em 476, com a deposição de Rómulo Augústulo, o último imperador romano do Ocidente, por Odoacro, rei dos Hérulos, abriu-se uma nova página na história política da Europa. Durante algum tempo, essa página ficou por preencher, pois as migrações continuavam. Os Visigodos e os Burgúndios, porém, acabaram por se estabelecer na Gália - onde já se encontravam os Francos - e ali formaram reinos próprios desde meados do séc. V, coabitando com a antiga população galo-romana.

Os historiadores tendem a suavizar a oposição entre o 'mundo romano' e o 'mundo bárbaro', mas as diferenças eram significativas. O primeiro fora um mundo centrado no Mediterrâneo, com um comércio intenso servido por vias de comunicação próprias, com um Direito uniformizado, um Estado centralizado e uma capital política - Roma; um mundo urbanizado e com uma classe senatorial que assumia o comando de um território demarcado por uma fronteira precisa: o limes. Já o 'mundo bárbaro' dizia respeito a povos seminómadas que praticavam a agropastorícia, num universo político sem unidade real, construído com base em agrupamentos de tipo tribal, a que estava associada uma cultura oral com um peso muito forte da tradição e uma coesão social baseada na palavra e no gesto, em juramentos e em testemunhos, e na prática de uma justiça assente no direito de vingança privada.

Romanos e Bárbaros há muito que se conheciam, pois as invasões foram precedidas por um longo período de concentração de povos bárbaros nas fronteiras do Império. As dificuldades sentidas por Roma a partir do séc. III d. C. acabaram por estimular os contactos entre Romanos e Bárbaros, em especial nas zonas fronteiriças, com a integração e romanização destes povos, acolhidos como soldados. Sobreviveu uma marca romana forte (vias de comunicação, moeda, campesinato de pequenos e médios proprietários, fiscalidade pública, entre outros aspetos), mas entre o séc. III e o séc. V a civilização romana evoluiu no sentido de uma maior ruralidade. Por isso, alguns autores defendem que as "invasões bárbaras" são um prolongamento da história romana, prolongamento esse que, na Gália, conduziu mais a uma mudança de regime do que a uma conquista. Aliás, os Bárbaros representavam só 2 a 3\% da população gaulesa...

Neste novo mundo, as cidades eram ainda muito pequenas, com uma média de 1500 habitantes, e dependiam muito da atividade do clero: das 
catedrais, das basílicas e dos mosteiros. A Igreja cumpriu um papel essencial na conservação da herança romana e pode dizer-se que o bispo era o protetor e o 'guia' das cidades, que eram sobretudo centros de artesanato e de troca relativamente incipientes. O cristianismo viria a ser um dos fatores mais importantes na fusão entre os ex-Romanos e os Bárbaros, que de início eram ou pagãos (como os Francos, os Alamanos, os Anglos, os Jutos e os Saxões), ou arianos, isto é, partidários de uma heresia que recusava a dimensão divina de Cristo (como sucedia com os Godos, com os Burgúndios e com os Lombardos).

\section{Uma Gália partilhada}

Entretanto, a Gália convertera-se na dinâmica 'casa dos Francos', e também de outros povos. As fronteiras eram ainda vagas, devido à instalação de novos grupos, às conquistas e às partilhas sucessórias. Mas o eixo civilizacional da Europa deslocava-se claramente do Mediterrâneo para a região situada entre o rio Loire (que divide a Gália em duas metades, norte e sul) e, mais a leste, o rio Reno. Seria aqui que a história do Ocidente teria o seu centro de gravidade nos primeiros séculos da Alta Idade Média, e não restam dúvidas de que quatro francos tiveram uma importância muito especial nessa evolução: Clóvis (481-511), Pepino I, "o Antigo" (m. 639), Carlos Martel (719-741) e Carlos Magno (768-814). Graças a eles, o código genético da Europa ficaria marcado por um triplo selo: romanidade, germanidade e cristianismo.

Existem testemunhos da presença dos Francos na Europa do Norte desde o séc. III. Da região das Ardenas (no nordeste da Gália) passaram depois para as zonas pantanosas da foz do Reno, nos confins da Gália do Norte. Formavam então um conjunto de tribos ousadas e livres (Sicambros, Sálios e outros) e ficaram ligados ao Império Romano após a derrota sofrida às mãos de Juliano, em 358. Tornaram-se então lètes, isto é, uma espécie de 'camponeses soldados' instalados em terras cedidas pelos Romanos a título hereditário, nas proximidades da fronteira, com a obrigação de integrarem o exército imperial em caso de necessidade. 


\section{O Mundo Merovíngio}

FRISIA SAXÕES

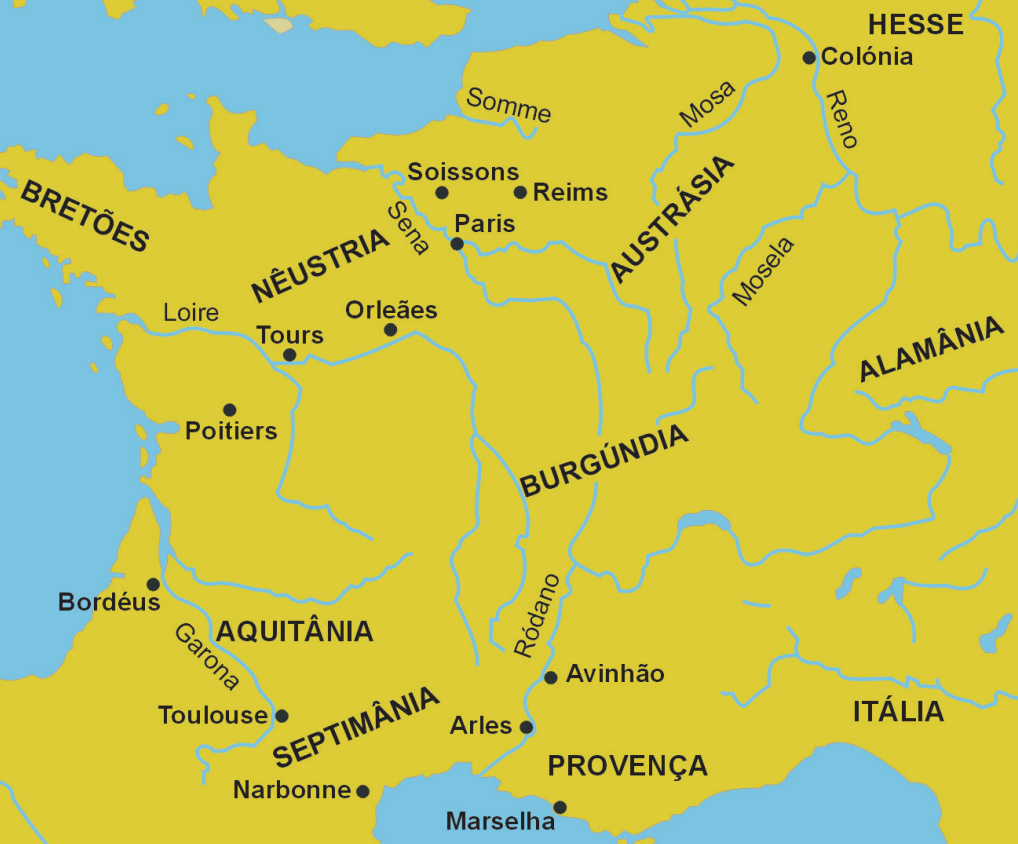

MAR MEDITERRAN

ÁFRICA Cartago 
O serviço militar acabou por romanizar os Francos; em meados do séc. v, passaram de lètes a "federados" e foram integrados no Império por meio de um tratado. Nessa época, apoiaram Flávio Écio a norte do Loire, contra os Hunos (na célebre batalha dos Campos Cataláunicos, em 451). Os Francos formavam então dois grandes grupos: os Francos Renanos, a leste, em torno de Colónia, com o estatuto de federados e compondo um só reino; e os Francos Sálios, a norte do rio Somme (Amiens), com o estatuto de federados a partir de 438, mas formando vários pequenos reinos guerreiros.

Nesta altura começou a destacar-se Childerico, o líder que levou a cabo o alargamento do pequeno reino dos Francos Sálios, situado na região de Tournai (atual Bélgica), até ao rio Somme. Destaque-se o apoio por ele concedido a Egídio, um general romano que esculpiu para si próprio uma espécie de reino no desaparecido Império Romano. Childerico lutou ao lado de Egídio contra os Visigodos e talvez por isso tenha recebido a administração da província de Reims. Childerico foi, portanto, um chefe federado bem-sucedido, rico e prestigiado. Em 481, ele transmitiria o seu reino, meio bárbaro e meio romano, ao seu filho Clóvis, numa altura em que os Francos eram ainda muito débeis diante dos outros reinos da Gália. Neste imenso espaço, os cinco mais fortes concorrentes eram então os seguintes:

i) os Francos dominando a norte do rio Somme, em zona de forte implantação germânica. Nesta época, ainda não estavam unidos;

ii) o reino de Siágrio, o filho de Egídio, onde havia ainda poucos germanos instalados. Siágrio detinha um reino independente, que devia a sua força a uma guarda militar composta por Bárbaros. Tratava-se, pois, de um rei romano mas 'barbarizado';

iii) os Visigodos, entre o rio Loire e o sul da Hispânia. Formavam um reino forte, dirigido por Eurico e, depois, por Alarico II;

iv) os Burgúndios, nos vales do Saône e do Ródano. O seu rei, à data da ascensão de Clóvis, era Gondebaud;

v) os Alamanos, recentemente entrados na Gália e ocupando o que é hoje a Alsácia e a Lorena, tal como o sudoeste da... Alemanha. 
Clóvis, o fundador

Clóvis (481-511) deve ter subido ao trono de um dos ramos dos Francos Sálios logo aos 15 anos. Nessa altura, passou a dispor do mund (isto é, do poder mágico do chefe guerreiro) e a ostentar a cabeleira comprida que constituía o símbolo da autoridade. O nome "Clóvis" (que depois deu "Luís") significava "combate glorioso" e o primeiro rei merovíngio fez por merecê-lo. Porém, ele não herdou só os costumes dos Francos, mas também a administração fiscal e judicial de Roma.

O grande projeto político de Clóvis era... rumar ao sul. Para isso, começou por construir uma aliança com os Francos Renanos, que na altura se encontravam pressionados pelos Alamanos. Daqui resultou o seu casamento com uma princesa renana. Depois, Clóvis conseguiu impor-se no seio dos restantes reis dos Francos Sálios e ficou então com as mãos livres para conduzir a sua política de expansão territorial a sul do Somme e enfrentar Siágrio, que logrou derrotar em 486, perto de Soissons.

Com esta vitória, e beneficiando de uma ligação precoce ao episcopado, Clóvis pôde estender a fronteira até ao rio Loire, tendo conquistado a região oeste, entre os rios Sena e Loire, até 494. Ficava agora face a face com os Visigodos, que eram arianos, o que lhe valeu o reforço do apoio clerical. Por esta época, Clóvis negociou alianças com os poderes dominantes no Norte de Itália: com Odoacro e, depois, com Teodorico, o rei dos Ostrogodos. E terá também requerido o batismo - na sequência do seu segundo casamento, com Clotilde, uma princesa católica da Burgúndia - e suscitado a admiração do imperador bizantino, que via nele um aliado contra Teodorico e os arianos.

Em 507, Clóvis conseguiria um grande êxito militar, ao vencer os Visigodos na batalha de Vouillé, junto a Poitiers. Os Francos (Sálios e Renanos) aliaram-se então aos Burgúndios para fazerem a guerra contra os Visigodos de Alarico II. Esta onda de sucessos permitiu a Clóvis as conquistas de Bordéus (na Aquitânia) e de Toulouse (cidade visigótica, já próxima do Mediterrâneo). Com isto, a situação político-militar no Sul da Gália alterou-se, tanto mais que, em 508, os Ostrogodos conseguiram recuperar a Provença. Ainda assim, todo o baixo Languedoc (a região central do extremo sul da Gália) permanecia nas mãos dos Visigodos, formando a "Septimânia". 
Em 509, Clóvis conseguiria ainda eliminar os pequenos reinos sálicos que subsistiam e impor-se em definitivo aos seus pares, sendo eleito como rei de todos os Francos, incluindo dos Francos Renanos. Resta referir um outro feito decisivo, ocorrido a nordeste mas para o qual a cronologia é incerta: a vitória de Clóvis sobre os Alamanos na batalha de Tolbiac, ferida em 496 ou em 506, nas proximidades de Colónia.

\section{O legado de Clóvis e os seus sucessores}

Clóvis, falecido em 511, foi um verdadeiro fundador e legou aos seus descendentes um poder político bem diferente daquele que herdara de Childerico. Devemos, no entanto, frisar que, diretamente, os sucessores de Clóvis, isto é, os "reis dos Francos", administravam apenas 2\% da Gália, estando sobretudo instalados ao norte do rio Sena. Para controlar as regiões conquistadas ao sul deste rio, enviavam-se administradores, condes e outros delegados do rei.

Ao mesmo tempo, a norte do rio Loire prevalecia ainda a Lei Sálica, de inspiração bárbara, enquanto, a sul do Loire, a marca visigoda se fazia sentir através do Breviário de Alarico, mais próximo da tradição jurídica romana. Para compensar esta divisão, havia agora a unidade religiosa: a conversão de Clóvis arrastara a do conjunto dos Francos e os próprios Burgúndios se converteram ao cristianismo em 516.

Clóvis, o primeiro monarca merovíngio, foi senhor de um vasto território, que se estendia do Reno aos Pirenéus, embora desta geografia devamos excetuar a presença dos Bascos, a dos Bretões (na futura "Bretanha" francesa), a dos Frisões (no delta do Reno, atual Holanda) e, a sul, a presença, já mais reduzida mas ainda forte, dos Visigodos. Todavia, a tradição bárbara impunha, à morte do monarca, a divisão do território pelos seus filhos. Assim, a primeira partilha do reino franco teve lugar em 511, quando Clóvis faleceu. Nessa altura, cada um dos seus filhos recebeu um território:

- Thierry (ou Teodorico, filho da primeira mulher de Clóvis) ficou com os territórios 'belgas' de origem dos Francos, mais a Champagne, tendo situado a sua capital em Reims; 
- a Clodomiro, filho de Clotilde, a segunda esposa de Clóvis, coube em sorte um território com capital em Orleães;

- Childeberto I, também filho de Clotilde, recebeu um reino com capital em Paris, junto ao rio Loire;

- e Clotário I, ainda filho de Clotilde, foi estabelecido numa posição intermédia, com capital em Soissons.

Todos residiam entre o rio Loire e o rio Reno (a região a que se chamava "Francia") e todos se intitulavam "rei dos Francos". É que o regnum Francorum era divisível - pois o património era deixado em herança aos filhos do monarca defunto, cada qual recebendo o 'seu' reino como um bem patrimonial -, mas, ao mesmo tempo, era uno, já que subsistia a ideia de um conjunto único! O poder régio não era, portanto, entendido como simplesmente territorial. Esta conciliação peculiar era possibilitada, por um lado, pelo princípio dinástico e, por outro, pelos estreitos laços de sangue que uniam os vários monarcas. O resultado disto, segundo Claude Gauvard, era um "equilíbrio harmonioso", traduzido na proximidade entre as várias capitais. Não havia, pois, anarquia, mas sim um método de governo entre vários homens distintos, ligados entre si pelo sangue. A unidade do regnum fundava-se no parentesco e dependia do bom entendimento entre os monarcas irmãos.

Durante o séc. VI, assistiu-se à prossecução da expansão franca, agora também para leste. Aqui, devemos salientar as campanhas de Thierry (sozinho ou com Childeberto e Clotário I) contra os Turíngios, as expedições de Teodoberto (filho de Thierry) contra a Alamânia e a Baviera, ou os ataques contra a Burgúndia, que permitiram a Clotário e a Childeberto conquistar esta região em 532-534. Os novos reis francos também combateram a norte, contra os Saxões, e a sul, contra os Visigodos, tendo Thierry e Childeberto conquistado a região entre o rio Garona e os Pirenéus em 531-532, confinando de vez os Visigodos gauleses à Septimânia. Os filhos de Clóvis ainda intervieram em Itália, tentando aproveitar a guerra entre Ostrogodos e Bizantinos. Finalmente, refira-se que a Provença lhes foi vendida no ano de 537.

A evocação destes eventos serve para mostrar as ambições políticas externas dos primeiros Merovíngios, legítimos continuadores do projeto de 
Clóvis. Contudo, dois perigos ameaçavam a harmonia do sistema: a ambição pessoal dos monarcas irmãos; e a eventual superioridade de um dos territórios sobre os outros...

\section{As três 'pátrias'}

Clodomiro morreu novo, tendo o seu território sido dividido entre Childeberto e Clotário. Apesar disso, Thierry e o seu filho Teodoberto parecem ter começado por levar vantagem, só que este ramo mais velho dos filhos de Clóvis desapareceria em 555. Nessa altura, Clotário aproveitou para usurpar a herança dos sobrinhos e reinou sozinho entre 558, data da morte de Childeberto, e 561. À morte de Clotário, houve lugar a uma nova partilha do reino franco. O procedimento adotado inspirou-se no que tinha sido utilizado cinquenta anos antes e o reino dos Francos foi dividido entre os quatro filhos de Clotário: Sigeberto (cujo reino teve capital em Reims); Gontran (com capital em Orleães); Cariberto (com capital em Paris); e Chilperico (com capital em Soissons).

Em 567, Cariberto morreu sem deixar descendentes, passando a restar três dos filhos de Clotário I. Então, estes três monarcas dividiram entre si o território que pertencera a Cariberto e ficaram a dominar três grandes regiões ou 'pátrias': a Austrásia (a região leste, incluindo a Frância renana e a Champagne), sob a tutela de Sigeberto; a Nêustria (a região oeste, que compreendia a zona de Tournai, a do Mans, a Normandia e a Île-de-France), sob o comando de Chilperico; e a Burgúndia (mais ao centro, formada pelo antigo reino dos Burgúndios e pelo reino de Orleães), sob a liderança de Gontran.

De certa maneira, isto representava um regresso ao passado, à época dos Francos Renanos, dos Francos Sálios e dos Burgúndios! Contudo, uma divisão do regnum Francorum em três grandes regiões com identidade própria não estava ainda amadurecida, e Paris até foi declarada como sendo a capital comum das três 'pátrias'. Todavia, esse elemento aglutinador não foi suficiente para impedir a eclosão da guerra, assistindo-se a décadas de lutas entre os filhos sobrevivos de Clotário I, com envolvimento das respetivas 


\section{Os Merovíngios: de Clóvis a Dagoberto I}

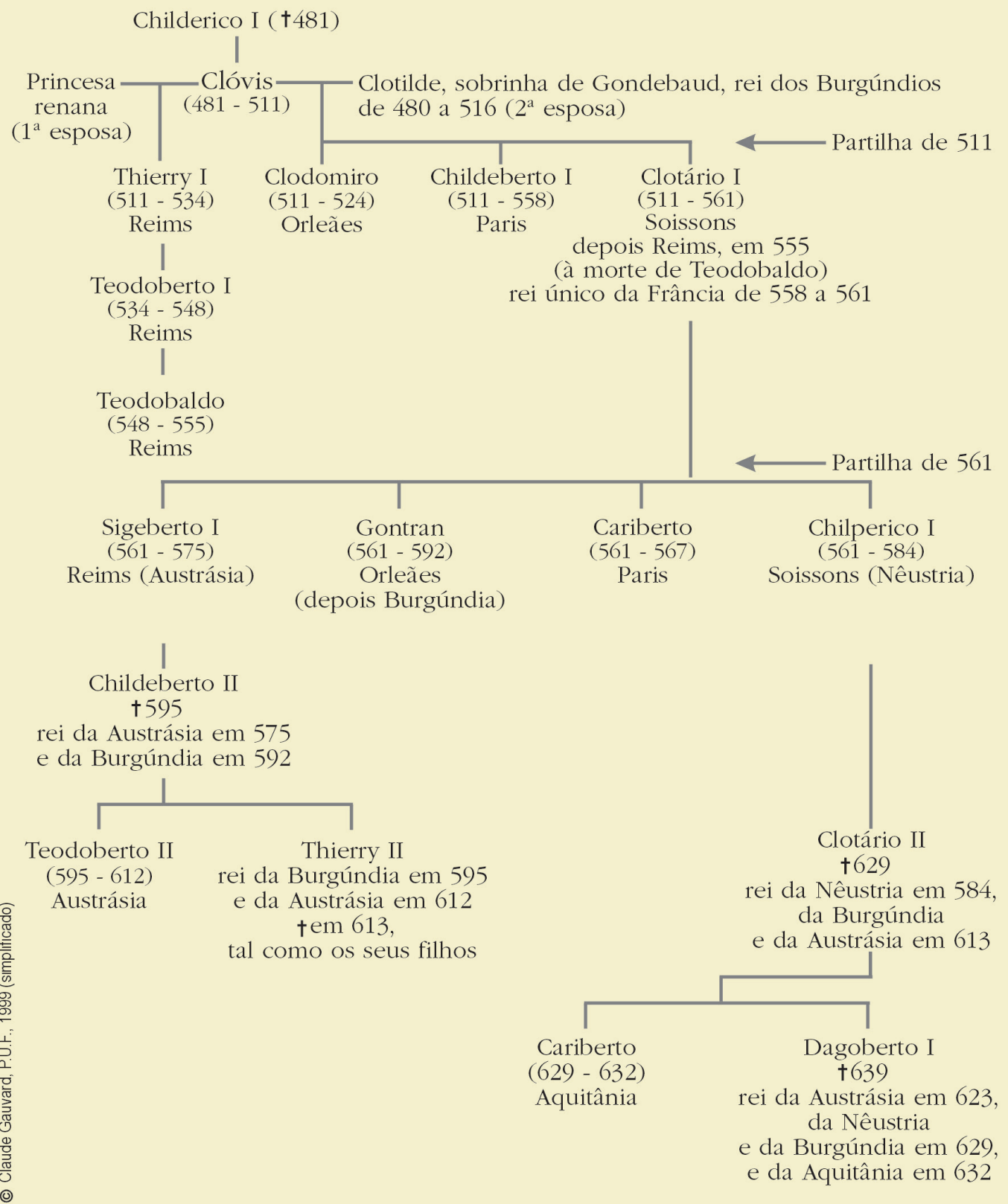


esposas e filhos. Neste quadro, destaque-se o facto de Sigeberto ter estado quase sempre em guerra com o seu irmão Chilperico: o antagonismo entre a Austrásia e a Nêustria tornara-se então uma constante.

Não cabe aqui recordar estas lutas, que dilaceraram a Gália dos Francos até cerca de 610. Delas acabou por sair beneficiado, numa primeira fase, Gontran, rei da Burgúndia, e, depois, Clotário II, um dos descendentes de Chilperico, que conseguiu governar como rei único dos Francos entre 613 e 629. O reinado de Clotário II foi calmo, mas sob o seu filho Dagoberto I (629-639) voltaram a surgir alguns sobressaltos. Dagoberto tinha noção de como as décadas recentes de disputas haviam cavado divisões profundas entre as três grandes 'pátrias' - a Austrásia, a Burgúndia e a Nêustria - e governou de forma firme mas sensata. Ele sabia que a guerra permanente favorecera as forças locais e a aristocracia em prejuízo da autoridade real, que desejava restaurar. Justamente por isto, muitos historiadores consideram Dagoberto I como o último monarca merovíngio 'a sério'. Ainda assim, ele não pôde evitar a escalada da nobreza palaciana e, em especial, daqueles poderosos que, pela sua influência e recursos, conseguiam chamar a si, em cada uma das três grandes 'pátrias' da Gália merovíngia, o desempenho do importante cargo de "prefeito do palácio" (major domus).

\section{Os Pipínidas entram em cena}

Um desses poderosos foi Pepino de Landen, ou Pepino I. Foi ele quem deu início à saga dos Pipínidas, de onde descenderiam os Carolíngios. Oriundo de uma família com imensos domínios e sólidas alianças na região média do rio Mosa, Pepino de Landen foi nomeado prefeito do palácio da Austrásia, tendo-lhe sido confiada a educação de Dagoberto I. Astuto, depressa construiu um partido aristocrático, através de ligações matrimoniais e com o apoio de novos mosteiros. A sua filha Gertrudes fundou o mosteiro de Nivelles (na atual Bélgica), onde se tornou abadessa. Uma outra filha, Begge, casou com o herdeiro de Arnulfo de Metz, um homem que possuía numerosos bens entre o Mosela e o Mosa, no coração da Austrásia, e que foi bispo de Metz. 
No clima de tensão que marcou o final da dinastia merovíngia, o cargo de prefeito do palácio acabou por se tornar hereditário. Assim, à morte de Pepino de Landen, em 639, Grimoaldo sucedeu ao pai como prefeito da Austrásia. O momento, contudo, não era auspicioso, pois, quando se dera o falecimento quase simultâneo de Dagoberto e de Pepino I, a Gália merovíngia entrara outra vez em crise. Tratou-se de um período agitado e que se prolongou até 680, com novos conflitos entre as três 'pátrias', agravados pelas guerrilhas entre as fações aristocráticas. Na Austrásia, em 656, Grimoaldo tentou instalar no trono o seu filho Childeberto, impondo uma mudança de dinastia. Porém, o golpe não foi bem-sucedido: os Neustrianos, liderados pelo seu prefeito do palácio, Ebroïn, reagiram e Grimoaldo e o filho foram executados. A família dos Pipínidas perderia, assim, a sua influência até ao início da década de 680.

Seguiu-se uma nova fase de disputas, interpretadas por Ebroïn, por Wulfoaldo, o prefeito do palácio da Austrásia, e pelo bispo Leodegar, que na Burgúndia simbolizava a resistência à assimilação. Ebroïn desenvolveu uma estratégia centralizadora, tentando ser reconhecido como prefeito do palácio nos três reinos merovíngios. Recusou aos Austrasianos o direito a terem um prefeito próprio, mas os nobres desta região, com Pepino II (ou Pepino de Herstal, o neto comum de Pepino I e de Arnulfo de Metz) à cabeça, recusaram a ideia. Daí veio a resultar, c. 680, o assassinato de Ebroïn...

Entrava-se, assim, numa fase crucial, marcada pelo regresso ao poder da influente e rica família dos Pipínidas, através de Pepino II, que se tornou prefeito do palácio da Austrásia perto do ano 680. A sua família conseguiu sobrepor-se e eliminar os prefeitos do palácio seus rivais. A partir desta altura, o cargo de major domus foi monopolizado pelos Pipínidas e imposto, definitivamente, como um cargo hereditário.

\section{Os "reis fantoches"}

O primeiro passo para a consagração dos Pipínidas foi a vitória na batalha de Tertry (no Norte da Gália), em 687, onde Pepino II derrotou o prefeito da Nêustria, Berchar, e os seus aliados burgúndios. De uma assentada, Pepino II vingava a morte do tio Grimoaldo e apoderava-se do tesouro do 
rei da Nêustria, Thierry III. Berchar morreria logo em 688 ou 689, posto o que Pepino II reivindicou a Nêustria e instalou aí o seu agente Nordeberto. Depois da demissão deste, Pepino nomeou o seu próprio filho Grimoaldo como prefeito do palácio da Nêustria, enquanto um seu outro filho, Drogo, recebeu o ofício de $d u x$ na região da Burgúndia.

Ainda assim, Pepino II, inteligentemente, manteve o rei merovíngio (Thierry III) no poder, e este passou a governar um reino novamente unificado (Austrásia-Nêustria-Burgúndia). No entanto, o monarca apenas conservava a auctoritas formal, pois o poder real passara para os prefeitos do palácio da Nêustria e da Austrásia, que pertenciam à família pipínida. Os prefeitos tomaram então o título de princeps e, com isso, entramos no período conhecido como o dos rois fainéants (os "reis fantoches").

Os últimos monarcas merovíngios não foram mais do que 'uma família entre outras'; empobrecidos, foram vítimas das linhagens aristocráticas. Ao seu lado, a força dos Pipínidas não cessava de aumentar: acumulação de riquezas em domínios de ponta no eixo do Mosa; apoio de um clero dinâmico; e controlo do cargo oficial de prefeito, o que lhes permitia dominar a vida política, diretamente ou por intermédio dos filhos.

\section{Carlos Martel}

Drogo e Grimoaldo faleceriam um pouco antes do seu pai, Pepino II (m. em dezembro de 714), o que abriria um período de crise sucessória. A viúva de Pepino II, Plectrude, queria o neto Arnulfo como prefeito da Austrásia e o neto Teodoaldo como prefeito da Nêustria, mas em 715 a oposição neustriana aclamou Raganfredo, um influente magnate local. Valeu aos Pipínidas a grande capacidade de Carlos Martel, filho de Pepino II e de Alpaida (sua segunda mulher), mau grado a contestação de que este foi alvo por parte de um setor da aristocracia austrasiana. Inicialmente detido na prisão pela madrasta, Carlos Martel, logo que conseguiu fugir, constituiu, com o apoio da aristocracia da região de Maastricht-Liège (dominada pela família de Alpaida), uma clientela de 'vassalos' fiéis, ligando o "benefício" (uma concessão temporária, geralmente uma terra obtida da Igreja) à prestação de um serviço militar. 


\section{Os Merovíngios: de Dagoberto I a Childerico III}

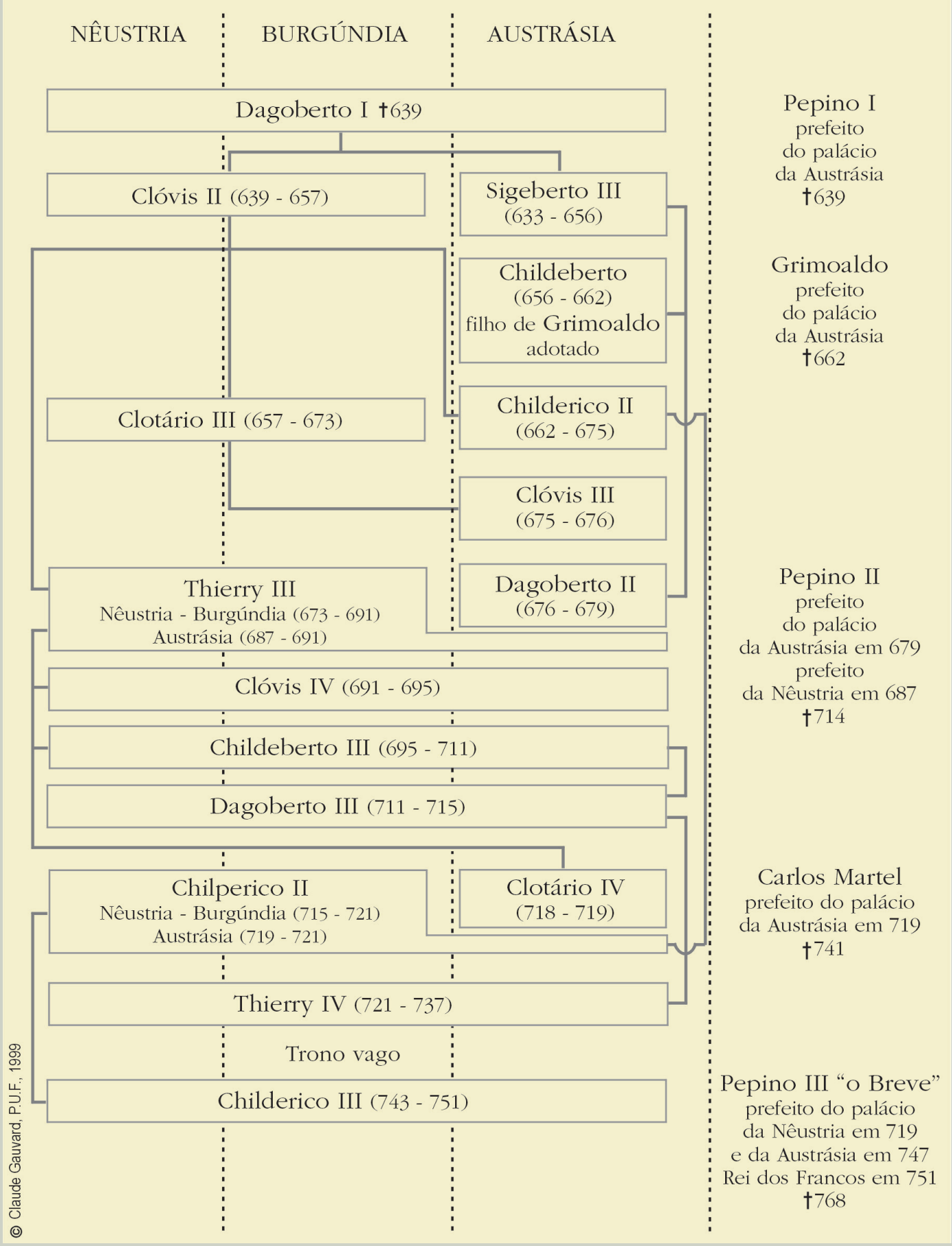


Nesta época, os Neustrianos ambicionavam tornar-se independentes e chegaram a derrotar os Austrasianos em Compiègne. O prefeito Raganfredo aliou-se também ao governante da Frísia, Radbod; juntos, derrotaram Carlos Martel perto de Colónia. Mas Martel soube reagir às primeiras adversidades e, com um exército bem organizado, conseguiu vencer os Neustrianos e os seus aliados em batalha: em Amblève (716), em Vinchy (717) e em Soissons (718), Martel vergou o prefeito do palácio da Nêustria, Raganfredo, e outro dos seus principais aliados, o duque Eudo da Aquitânia, que aspirava à independência. Deste modo, em 719 ou 720, Carlos Martel foi reconhecido como prefeito do palácio da Austrásia, alcançando um poder generalizado. Apesar disso, conservou o 'rei' Chilperico II no poder na Nêustria.

São impressionantes as vitórias subsequentes obtidas por Carlos Martel, um dos generais mais notáveis da Alta Idade Média: a leste, controlou as rebeliões na Baviera (em 725 e 728) e na Alamânia (em 725, 728 e 730) e fez campanha contra os Saxões (em 720, 722, 724 e 738); a norte, esmagou os Frisões de Radbod (na década de 720); e, a sul, lutou muito para submeter a Burgúndia e a Aquitânia (vide mapa da p. 147). Em 739, Martel tinha estabelecido o seu domínio sobre todo o regnum Francorum e sobre os povos que nele habitavam - reinava agora sobre um espaço comparável ao de Dagoberto I (em 639) ou ao de Clotário I (em 561). A ocidente, a Austrásia, a Nêustria, a Aquitânia e a Burgúndia; mais a leste, a Frísia, o Hesse, a Alamânia, a Turíngia e a Baviera: todas reconheciam o regnum de Carlos Martel, embora nem todas estivessem formalmente integradas no seu principado (caso dos ducados da Baviera e da Aquitânia).

Carlos foi, portanto, um chefe de guerra, mais do que um governante, e ficou, aliás, a dever o seu sobrenome ("Martel") às repressões e pilhagens com que massacrou as regiões meridionais. À boa maneira bárbara, a guerra era também... uma razia!

\section{Os Árabes na Gália}

Do lado dos muçulmanos, a sua movimentação na Gália nos inícios do séc. VIII tem de ser relacionada com a conquista da Península Ibérica. Em julho de 710, o governador muçulmano de África e do Magrebe, Musa ibn 
Nusayr, ordenou a um seu oficial que procedesse a um reconhecimento do território ibérico, dominado pelos Visigodos. Feito isso, Musa encarregou o seu lugar-tenente, Tariq ibn Ziyad, governador de Tânger, de organizar um exército e de avançar para a Península.

Tariq assim fez e, na primavera ou no verão de 711 , tiveram lugar as primeiras conquistas muçulmanas na Hispânia. Destas operações veio a resultar, em julho de 711, a batalha de Guadalete, ou de Janda-Barbate, em que os muçulmanos, chefiados por Tariq, derrotaram os Visigodos e mataram o seu rei Rodrigo. No verão ou no outono de 712, foi a vez de Musa entrar na Península, tendo conquistado Sevilha, Málaga e Granada. A conquista da Hispânia pelos muçulmanos prolongar-se-ia até 716 .

Entretanto, as aspirações árabes de conquista territorial não se confinavam à Península. A partir daqui, os muçulmanos dirigiram também as suas atenções para a região meridional da vizinha Gália. Em 721, um exército muçulmano chefiado por Al-Sahm cercou e capturou Narbonne e depois sitiou Toulouse, mas o duque Eudo, com uma força de aquitanos e de seguidores francos (talvez descendentes dos magnates outrora exilados por Ebroïn), derrotou o líder árabe e repeliu-o da Gália. Al-Sahm foi morto, mas o seu sucessor, Anbasa ibn Suhaim al-Kalbi, foi mais bem-sucedido: cercou Carcassonne e Nîmes, na Septimânia, e fez raides para norte, até Autun ou Luxeuil.

Enquanto a força de Al-Kalbi estava concentrada na Burgúndia, um outro grupo, comandado por Abd al-Rahman ibn Abd Allah al-Ghafiqi, que o califa omíada renomeara em 729-730 como governador do al-Andalus, atravessou os Pirenéus com um exército que reunia tropas recrutadas na Hispânia e em África, forte em cavalaria e composto essencialmente por Árabes e por Berberes. Em 731, Abd al-Rahman eliminou o seu rival Munnus, um berbere que comandava as tropas muçulmanas no sudeste dos Pirenéus e que se tinha aliado ao duque Eudo da Aquitânia. No verão de 732, Abd al-Rahman avançou contra Bordéus.

Eudo enfrentou al-Rahman na confluência do rio Dordonha com o Garona, mas, ao contrário do que acontecera em 721, altura em que defrontara um exército muçulmano composto sobretudo por infantaria ligeira, desta vez Eudo foi pesadamente derrotado. A seguir, os Árabes, movidos mais pela intenção de devastar a região aquitana do que de a conquistar, avançaram 
para Poitiers, que incendiaram e onde saquearam a igreja de Santo Hilário. Tomaram depois a estrada de Tours, talvez com a intenção de saquear a cidade, que conservava a memória sagrada do bispo São Martinho.

Alarmado, o duque Eudo não teve outro remédio senão fugir e pedir socorro a um seu velho inimigo: Carlos Martel, o poderoso dux dos Francos, que ainda no ano anterior tinha invadido a Aquitânia para a sujeitar à sua obediência... Consciente da necessidade de travar os muçulmanos, Carlos Martel correspondeu ao apelo e preparou um exército capaz de enfrentar os invasores. As duas hostes acabariam por se encontrar algures no trajeto entre Poitiers e Tours, dando origem à batalha que estamos a evocar.

\section{Fazer a guerra na Europa da Alta Idade Média}

Antes, porém, da narrativa da batalha, é imprescindível dizer algo sobre a arte militar europeia entre 450 e 900. Como era feito o recrutamento militar, que dimensão tinham os exércitos, que armas utilizavam os guerreiros, que princípios gerais presidiam às campanhas e quais as soluções táticas adotadas em combate?

\section{O recrutamento militar}

Em termos gerais, podemos dizer que os exércitos dos primeiros Carolíngios (isto é, a partir de Carlos Martel) eram compostos por quatro parcelas: um núcleo duro de tropas da Casa Real (guarda-costas do monarca e outros); os magnates ligados ao rei, com os seus guardas e séquitos próprios e podendo trazer outros aristocratas; os homens livres recrutados entre a população (sobretudo nas zonas ameaçadas); e os auxiliares externos (povos tributários, aliados ou mercenários contratados pelo rei).

Recuando um pouco, verificamos que, no período subsequente à queda do Império Romano do Ocidente (476), a intervenção do rei e dos seus oficiais (em especial dos "antrustiões", o corpo de guardas pessoais do monarca) parece ter sido determinante. O recrutamento da população teria 


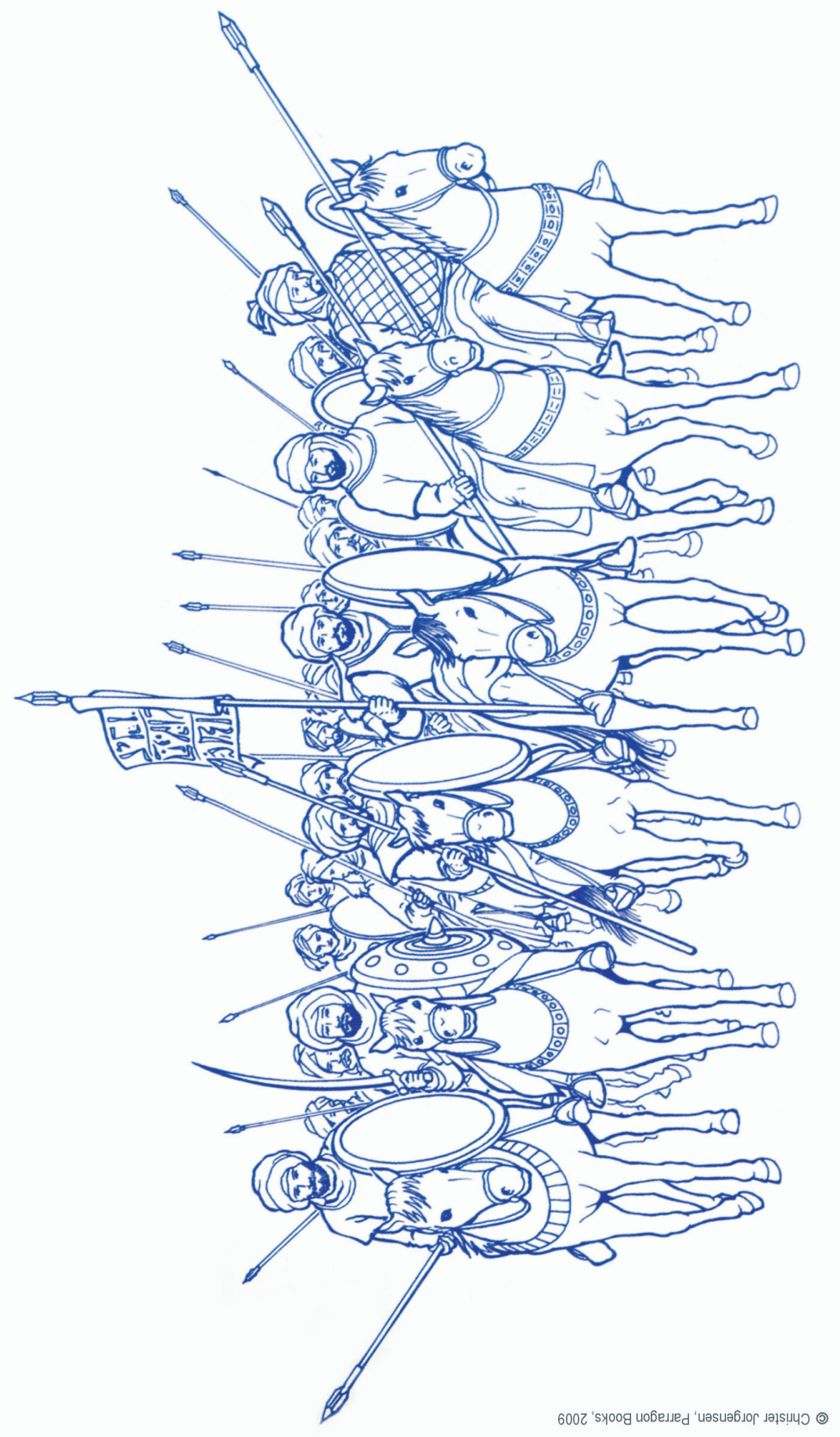

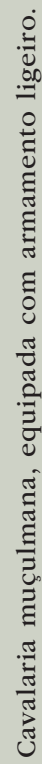


uma estrutura regional e estaria ainda inspirado pelo princípio (romano) do serviço militar obrigatório. Quem se escusava a prestá-lo tinha de pagar uma indemnização: o haribannus. Para os que serviam com empenho e com sucesso o seu chefe (o monarca ou algum dos magnates), havia recompensas, muitas vezes em terras e outorgadas a título permanente. Este sistema permitia manter a Coroa no centro do processo, já que era ela a fonte de tais recompensas e, portanto, era ela que possibilitava a existência de novas doações.

A partir de 700, aproximadamente, e na sequência das guerras constantes entre as diversas fações aristocráticas no mundo merovíngio, a realeza começou a perder influência. A reorganização da propriedade rural ajudou a gerar excedentes fundiários, que tornaram mais fácil a constituição de séquitos armados: o poder das elites locais aumentou e a Coroa começou a ser obrigada a negociar com esses 'notáveis' a sua participação nas campanhas militares. Principiaram a desenvolver-se novas formas de recompensa, a título precário, ao mesmo tempo que as relações sociais e políticas evoluíram para compromissos pessoais assentes em juramentos de fidelidade, por vezes com implicações em termos de prestação de um auxílio militar. A monarquia procurou adaptar-se atraindo as elites para o serviço militar do rei e tornando as recompensas dos seus fideles mais diversificadas: doações, protagonismo sociopolítico, atribuição de cargos (bonores) aos quais estavam associados benefícios económicos, entre outras. Quanto à população dos homens livres, combateu-se algum relaxamento das obrigações militares, articulando a posse da terra com a comparência no exército, em especial para tarefas defensivas. Com Carlos Magno (768-814), este sistema clarificar-se-ia sob a forma do adiutorium: nem todos os homens tinham de ir à guerra todos os anos, mas os mais pobres (os que detinham porções de terra inferiores a c. 50 hectares) deveriam associar-se em pequenos grupos e equipar rotativamente um deles, que asseguraria em nome do grupo a participação na campanha militar desse ano. O haribannus foi reanimado, gerando receitas que o rei podia aplicar na contratação de mercenários (em número ainda reduzido).

Este sistema permitiu aos primeiros Carolíngios dispor regularmente de tropas não muito numerosas, mas eficientes, muitas delas a cavalo e razoavelmente equipadas. O modelo pressupunha também o envolvimento 
dos proprietários fundiários livres ligados à Igreja, que podiam ser utilizados em serviços de vigilância ou em tarefas de construção e manutenção de pontes. Ao mesmo tempo, otimizou-se o recurso às scarae, que eram corpos militares selecionados muito ligados ao rei e que podiam ser rapidamente mobilizados para intervenções pontuais em cenários de crise.

Tem-se discutido muito o volume dos efetivos militares que os reis merovíngios e carolíngios conseguiram reunir. Tendo em conta a população da Gália, o reduzido tamanho das povoações, o grande número de isenções de serviço militar, as limitações logísticas da época e as dificuldades de organização das colunas de marcha, não é admissível que tais exércitos possam, no período merovíngio, ter atingido mais do que 5000 a 6000 homens e que, no séc. VIII, esse número possa ter ultrapassado muito os 10000 a 15000 combatentes. Treino militar, não parece que tenha existido: estes exércitos não eram permanentes, mas sim recrutados ad hoc para cada campanha. Só as tropas da Casa Real, em especial as mobilizáveis no âmbito de uma scara, podiam ter algo que se assemelhasse a um adestramento militar regular; o resto vinha com a experiência, pois estas sociedades estavam organizadas para a guerra e a sua matriz bárbara e guerreira não permitia grandes períodos de inatividade militar.

\section{As armas ofensivas}

No que diz respeito ao armamento, as fontes (literárias, pictóricas e arqueológicas) permitem-nos destacar quatro armas ofensivas. Para começar, a espada, que era bastante comum e apreciada, apesar de ser uma peça cara, fabricada com a melhor tecnologia da época. Devemos distinguir entre, por um lado, as espadas longas (no estilo da spatha romana), com guardas retas, lâminas de dois gumes e pomo, mais próprias para 'cortar' do que para 'estocar' e, porventura, mais adequadas para o uso a cavalo; e, por outro, as espadas curtas (na linha do gladius hispano-romano), ideais para o combate corpo a corpo. Quem não podia adquirir uma espada usava o scramasax, de início pouco mais do que uma 'faca longa', que no séc. VII se tornou mais larga e comprida até se converter, c. 700, numa espada curta de um só gume. 
Temos depois a lança, a arma mais comum e que, até à era dos Vikings (séc. IX), todos traziam. É a peça mais representada nas sepulturas e tinha um grande valor simbólico, sendo usada na entronização dos reis. Conhecem-se três variantes de lanças alto-medievais: as lanças curtas, de arremesso; as lanças compridas, com lâmina larga em forma de folha, boas para talhar e perfurar e usadas com as duas mãos; e o ango, uma lança muito próxima do pilum romano, com notável capacidade de perfuração e própria para arremessar a curta distância, antes do contacto corpo a corpo.

Em terceiro lugar, temos os machados, menos comuns do que se julgava e que apenas foram populares em certas épocas e regiões. Havia dois grandes tipos: os machados de guerra, manejados com uma mão; e os machados de arremesso, chamados franciscae, mas que (apesar de o nome o sugerir) não foram inventados pelos Francos, devendo antes ser uma herança do mundo romano. Representada na Gália, mas também no sul da Alemanha e da Inglaterra, a francisca era uma arma poderosa, com o gume superior em forma de letra "S"; o seu manejo pressupunha muita habilidade e bastante treino. Tal como o ango, começa a rarear no séc. VII. No séc. IX, os Vikings revitalizaram o machado de guerra, mas não ainda o de cabeça dupla, que só surgirá a partir do séc. X.

Finalmente, havia o arco e a flecha, dispondo-se de provas irrefutáveis da sua utilização tanto por Francos como por Ostrogodos, Lombardos ou Visigodos. Falamos de arcos simples, de madeira, com um alcance que não excederia os $180 \mathrm{~m}$; o testemunho de algumas fontes leva a pensar que seriam sobretudo utilizados por jovens guerreiros em fase final de formação.

\section{As defesas de corpo}

Quanto a proteções exteriores, predominavam os escudos redondos ou ovais (os escudos em forma de lágrima só surgirão mais tarde), fabricados em madeira e, provavelmente, planos, podendo a sua representação em formato convexo ter sido uma convenção pictórica. Tinham um buraco circular ao centro, para aplicação da pega, sendo o punho protegido por uma bossa ou cúpula metálica que permitia a utilização do escudo como arma ofensiva, para 'esmurrar' os adversários. As correias eram simples, 
permitindo um manuseamento bastante livre destas peças, muitas vezes decoradas. O facto de se estragarem muito em combate levava à presença de vendedores de escudos nos trens de apoio das hostes.

Em matéria de 'vestuário militar', devemos destacar as cotas de malha metálica, sobretudo no caso dos guerreiros mais próximos da Casa Real ou dos séquitos dos grandes magnates; os menos ricos envergavam proteções de couro, ou acolchoadas. Para as pernas, havia grevas de talas, meras tiras de metal atadas em cima e em baixo. Por fim, havia que proteger a cabeça, usando elmos parecidos com os modelos que se conhecem para o Império Romano: duas ou mais placas articuladas por meio de ganchos, por vezes completadas com máscaras de rosto, com proteções de nariz e de bochecha ou até com aventais de malha para defesa do pescoço. Os guerreiros mais pobres recorriam a coifas de couro ou de tecido, pois, qualquer que fosse a técnica de combate, a proteção da cabeça era essencial.

\section{Funções e custo do equipamento bélico}

Estamos, assim, muito longe dos cenários de Hollywood, com bárbaros seminus pintados de cores vivas e vestidos de peles selvagens a lutar nos campos de batalha dos sécs. V a IX. Entre estas duas balizas cronológicas, a evolução não parece ter sido grande, mas claro que os procedimentos táticos privilegiaram certas armas em detrimento de outras; além disso, as armas variavam um pouco, em função da natureza das campanhas e da cultura de cada povo. Note-se ainda que o efeito moral do equipamento contava quase tanto quanto a sua eficácia, o que ajuda a explicar os elmos e os escudos pintados, os cinturões de espada adornados, as lanças decoradas e as plumas, que aumentavam a estatura real dos combatentes. A função do 'vestuário militar' também passava por aí: suscitar o terror e provocar a fuga dos adversários.

Em termos de custos, estima-se que um equipamento completo pudesse equivaler a 20 bois ou 40 vacas! Segundo a Lei Ripuária, de inícios do séc. VII, uma espada podia custar o mesmo que 1008 pães de trigo, e no séc. IX um cavalo de topo andaria pelo equivalente a 2280 pães de trigo. 
Mas repare-se que estamos a falar de uma economia muito diferente da nossa, muito mais 'sociológica' e menos monetarizada, que não se regia pela simples lei da oferta e da procura: os mesmos bens tinham valores diferentes consoante o seu uso social, o proprietário anterior ou o prestígio do doador...

\section{Os cavalos}

Uma palavra também acerca da utilização dos cavalos na guerra. Sabemos que isso era comum, ainda que o combate pudesse vir a ser travado a pé. Já se criavam cavalos de guerra, sobretudo nas granjas reais. No entanto, as selas eram simples e os métodos de controlo das montadas privilegiavam - tanto quanto o uso das esporas ou das rédeas - a utilização dos joelhos, deixando as mãos livres para o manejo das armas.

Quanto aos estribos, devem ter sido introduzidos pelos Ávaros a partir de finais do séc. VI, sendo originários da China e da Pérsia. No entanto, o aparecimento do estribo, por si só, não levou ao nascimento da carga da cavalaria pesada, método de combate que o Ocidente não conheceu antes dos sécs. X ou XI. Ainda assim, o estribo permitia viagens longas mais confortáveis e, em combate, permitia a um cavaleiro levantar-se da sela e aplicar com a sua espada golpes violentos de cima para baixo, ou mesmo para a retaguarda. Não se conhecem ainda armaduras para os cavalos, apesar de sabermos que eles eram ricamente decorados com placas de ouro, de prata ou de bronze, como forma de ostentação social, sendo as rédeas muitas vezes ornamentadas com presas de javali, para intimidação dos inimigos.

\section{Fazer campanha}

Com um exército assim recrutado e equipado, partia-se para uma guerra que assumia formas que têm surpreendido os historiadores modernos. É que as batalhas foram bem mais frequentes do que em outras épocas, revelando a disponibilidade dos generais para combater em campo aberto. 
A explicação para este facto deve repousar em duas circunstâncias. Por um lado, a identidade social, na Alta Idade Média, pressupunha a capacidade dos reis e dos aristocratas para fazer a guerra e para derrotar os seus adversários. A batalha era muitas vezes necessária, não apenas para preservar o controlo de um território, mas também para consolidar uma realeza ainda frágil e para reforçar a base militar da nobreza ou a identidade étnica. A guerra era uma forma de ascensão social e permitia reafirmar a masculinidade e os laços de amizade e de dependência. Por isso, a aristocracia bárbara estava sempre sedenta de combate. Por outro lado, a batalha era a principal fonte de lucro da guerra alto-medieva, mais até do que a captura de uma cidade: os reis faziam-se geralmente acompanhar dos seus tesouros, os trens de apoio guardavam despojos valiosos e era grande a ostentação do equipamento dos guerreiros e das suas montadas. Por isso, a batalha... valia a pena!

Muitas vezes, as batalhas colocavam frente a frente hostes bastante reduzidas, com escassas centenas de guerreiros. Apesar disso, o resultado podia ser relevante, bastava que ocorresse a morte de um príncipe ou de um grande chefe militar. Geralmente, os desafios para combater surgiam em lugares conhecidos, historicamente significativos, e tirando proveito do facto de a circulação dos exércitos se fazer por um número limitado de estradas e de existir ainda escassa exploração do terreno e do adversário.

O verão era a estação da guerra. Os reis dos Francos transferiram a assembleia (romana) do Campo de Março para inícios de maio e era aí que, todos os anos, avaliavam os seus recursos financeiros e militares, a sua base social de apoio e as condições políticas de que dispunham (ou não) para partir para mais uma campanha. Se os sinais eram animadores, fazia-se a guerra até finais de setembro ou outubro, para aproveitar a abundância dos pastos, as estradas transitáveis e as colheitas disponíveis nos campos. Como demonstram as capitulares carolíngias (isto é, os 'decretos régios'), os guerreiros deviam trazer de casa o seu próprio equipamento, provisões para três meses e roupa para cerca de seis meses. Para facilitar a logística, mas também por razões estratégicas (dividir a atenção e os recursos do inimigo), os exércitos carolíngios costumavam subdividir-se em duas ou três colunas, que evoluíam de forma autónoma mas previamente concertada e em função de um objetivo estratégico comum. 
Os exércitos dos Francos raramente percorriam distâncias superiores a $15 \mathrm{~km}$ por dia (devido também ao volume dos seus trens de apoio) e, a partir de Clóvis, garantiam previamente o apoio divino: as hostes integravam bispos, pregadores, relicários, pedaços da Vera Cruz e outros símbolos e alfaias litúrgicas, existindo um serviço religioso cuidado, sobretudo nas vésperas dos combates. Afinal, o resultado de uma batalha campal era visto como um ordálio, ou seja, como um juízo de Deus, e havia que acautelar previamente que este pudesse ser favorável. Para os exércitos em trânsito, os grandes riscos tinham que ver com a fome e com a doença (disenteria, coqueluche, febres por ingestão de água imprópria), mas também há notícia de muitas deserções, que as capitulares carolíngias prometem punir com a pena de morte, porque podiam enfraquecer uma hoste antes de um combate decisivo.

A frequência da batalha campal (recorde-se como Clóvis e Carlos Martel se impuseram entre os Francos) não significa que não fosse importante capturar cidades. No entanto, isso não implicava sempre o desenvolvimento de uma operação de cerco convencional: um exército podia devastar os arredores da praça e aparecer depois para intimidar e desafiar os sitiados, estimulando a deserção. Como as técnicas de cerco eram relativamente grosseiras (embora esteja documentada a sobrevivência de alguma artilharia romana), a operação redundava muitas vezes numa espécie de 'troca de donos', com muita negociação com as forças locais e com o pagamento de pesados tributos a evitarem a perda de vidas humanas.

Em todo o Ocidente, entre 450 e 900, predominaram as operações transfronteiriças, traduzidas em raides e cavalgadas devastadoras, que, todavia, nem sempre evitavam a eclosão de uma batalha campal. Como em todas as épocas, neste período a guerra conheceu escalas muito diferentes e foi sempre pontuada por períodos de apaziguamento, que refletem a existência de 'amortecedores de tensões', como tratados, embaixadas, leituras públicas de acordos, éditos da Igreja, concílios, ou outros. Existia também um 'código tácito de guerra', que previa que se poupassem as igrejas e os territórios eclesiásticos, os prisioneiros mais importantes e as camadas mais indefesas da população. Quando, porém, surgiam adversários com outros padrões culturais (como os Vikings), ou com outras crenças religiosas 
(como os muçulmanos), ou quando a escalada de violência ultrapassava os níveis habituais, a guerra podia atingir picos inusitados. Foi o que sucedeu na Saxónia, em 782, quando Carlos Magno, saturado da felonia dos seus adversários (contra os quais fez mais de uma vintena de campanhas!), optou por massacrar 4500 Saxões no próprio local do combate e por deportar cerca de 10000 famílias para a Gália e para a Germânia...

\section{As táticas de combate}

Resta considerar as táticas adotadas, em especial numa batalha campal, esse enorme concentrado das mais intensas e extremas emoções humanas (como lhe chamou Guy Halsall), onde os fatores aleatórios pesavam de tal forma que jamais era possível prever com segurança qual seria a sentença divina.

O nosso primeiro alerta é para a insuficiência das fontes, que estão repletas de classicismos, de estereótipos e de superficialidades. Além disso, a maioria é do séc. Ix e é muito desaconselhável fazer retroprojeções. Nitardo descreve a importante batalha de Fontenoy, em 841, entre os netos de Carlos Magno, em que participou pessoalmente; e Asser relata largamente a batalha de Ashdown, ocorrida 30 anos mais tarde, entre os Ingleses e os Vikings. Trata-se de batalhas com intérpretes muito diferenciados e em geografias distintas; no entanto, depois de lermos as duas narrativas, achamos que foram combates muito semelhantes. Guy Halsall, parafraseando o comentário de Lars Lönnroth sobre os versos dos primitivos jograis escandinavos, resume a nossa deceção dizendo que tudo o que ficamos a saber, depois de endireitarmos a sintaxe e de decifrarmos as intricadas metáforas, é que certo governante, servido por bravos guerreiros, derrotou os seus adversários em tal ou tal sítio, tornando com isso mais feliz a vida dos lobos comedores de cadáveres e das aves de rapina locais... Tem razão: pelos relatos de Nitardo e de Asser, nem sequer ficamos a saber que a batalha de Fontenoy foi travada a cavalo e a de Ashdown a pé!

Ainda assim, há um ponto que podemos desde já fixar: o guerreiro da Alta Idade Média era um guerreiro versátil, pois tanto combatia a pé como 
a cavalo, no corpo a corpo cerrado como à distância, lançando projéteis. Não vale a pena tentarmos reduzir a realidade dos sécs. V a IX aos esquemas da Época Moderna, com distinções formais entre armas de 'cavalaria' e de 'infantaria'. Isso, pura e simplesmente, não existia ainda.

Conhecemos muitos exemplos de combates a cavalo. Gregório de Tours, por volta do ano 600, diz que tanto quanto a memória dos homens alcança os Francos são recordados como combatentes montados. E os cronistas bizantinos Procópio e Agátias, que relatam as lutas contra os Godos, os Vândalos, os Lombardos e os Francos nos sécs. V e vi, retratam estes povos a combater a cavalo. Além disso, há muitas esculturas em pedra que representam cavaleiros, e sobreviveram muitos adereços de cavalo nas sepulturas dos sécs. V a viI, tanto no Norte da Gália como na Germânia ou na Escandinávia. Também se sabe hoje que a (rara) inatividade militar de Carlos Magno em 792-793 teve que ver com uma terrível epidemia equídea.

Temos igualmente muitos testemunhos de combates a pé. O imperador romano do Oriente, Maurício (582-602), no tratado Strategikon, critica até os guerreiros ocidentais por terem demasiada disponibilidade para desmontar. E numa carta ao bispo de Laon, em 849, o intelectual Loup de Ferrières dá conta da sua incapacidade para ser um bom soldado e para executar os deveres de infantaria e de cavalaria, mostrando que um bom guerreiro devia saber combater das duas formas. Talvez em batalha campal se lutasse mais a cavalo e, em escaramuças, mais a pé, mas nada disto é rígido, e suspeitamos que as incursões dos Vikings, a partir dos finais do reinado de Carlos Magno, podem ter estimulado o combate a pé. No entanto, quando falamos em combate a cavalo, não nos referimos a nenhuma cavalaria de choque, supostamente inventada por Carlos Martel na sequência da generalização dos estribos: isso é um mito que devemos desfazer. Os Carolíngios foram superiores, sim, mas pela sua grande disciplina e capacidade táticas e pela sua ótima gestão da logística militar.

Atendendo a que a batalha campal, embora apetecível, tinha os seus riscos, era frequente tentar surpreender o inimigo quando este estava mais vulnerável, em especial quando ainda dormia, aproveitando-se também a luz oblíqua da madrugada. Para isso, ensaiaram-se por vezes marchas noturnas, que também comportavam os seus perigos, como Carlos "o Calvo" (neto de 
Carlos Magno) pôde constatar em 876, a caminho de Andernach, quando o seu exército se perdeu na escuridão e na chuva intensa dos caminhos. Outra possibilidade consistia em preparar emboscadas em sítios estratégicos, tal como os Bascos fizeram à coluna de Carlos Magno em Roncesvales (em 778 ou em 808), episódio que a Canção de Rolando imortalizaria. Um especialista nesta modalidade de combate era o comandante militar dos Burgúndios, Múmulo, que em 572 arrasou os Lombardos com um sistema de árvores empilhadas, que travou a coluna invasora e antecipou o respetivo massacre nos bosques do sudeste da Gália. Também os exércitos que regressavam a casa carregados de despojos eram vulneráveis, porque tinham pouca mobilidade e, em geral, entravam em euforia antes do tempo. As emboscadas e os raides podiam também ajudar a preparar o cenário para uma batalha campal em circunstâncias mais favoráveis.

Os generais da Alta Idade Média sabiam acumular outras vantagens antes de batalhar: gostavam de escolher o terreno, preferiam ocupar os pontos altos e tinham em atenção a posição do Sol. Na decisiva batalha de Tertry, em 687, Pepino II observou o campo de batalha na tarde anterior e mandou os seus homens mudar de posição, de maneira a que, no dia seguinte, os Neustrianos tivessem de combater com o Sol nos olhos. Os líderes também sabiam fazer discursos inflamados de exortação das tropas e os melhores preocupavam-se em recapitular aos seus soldados os procedimentos a adotar no momento do combate. Uma boa liderança também era indispensável e não foi por acaso que, no séc. VII, atacados pelos Mercianos de Penda, os Anglos orientais foram buscar o seu rei Sigeberto ao mosteiro onde vivia e o forçaram a comandá-los...

Sabemos muito pouco sobre os dispositivos táticos adotados em batalha. No entanto, adivinha-se uma evolução nas técnicas de combate, ao longo da Alta Idade Média: a escassez, a partir do séc. VII, de representação das franciscae, dos angones e das bossas de escudo com remates discoidais metálicos sugere que, por volta do ano 600, se terá passado de um estilo de combate mais fluido, com bastante espaço e esgrima individual, para um género de luta em formações muito mais cerradas, propícias ao combate corpo a corpo, um pouco à maneira da falange antiga. A menor popularidade dos arcos nesta segunda fase e, ao invés, a difusão do scramasax e o alargamento do tamanho dos escudos parecem apontar no mesmo sentido. 
Não se sabe bem o que poderá ter originado esta evolução, mas é provável que o facto de os exércitos serem mais numerosos tenha contribuído para ela, pois o número de efetivos era um fator muito importante no combate em falange. Também a influência dos Vikings, que faziam um uso inteligente do terreno e das fortificações de campo, pode ter ajudado, assim como o desejo de se encontrar um antídoto eficaz contra os exércitos que recorriam a formações mais folgadas e ao disparo de projéteis.

Estas formações compactas, que parecem predominar a partir do séc. VII, são conhecidas por "paredes de escudos". Fredegário, quando evoca um combate entre duas falanges de Francos travado em 612, observa que o espaço era tão exíguo que nem havia sítio para os mortos caírem, pelo que continuavam de pé, como se ainda estivessem vivos! Desconhecemos a profundidade destas falanges, mas é difícil admitir que tivessem muito poucas fileiras, pois o risco de rompimento da linha seria elevado.

É provável que as hostes desta época se organizassem em mais do que uma unidade e que os chefes tentassem garantir, dentro de cada uma delas, uma forte afinidade, já que era importante para os guerreiros, sobretudo quando combatiam a pé, terem alguém conhecido a lutar junto de si. Esses vínculos interpessoais podiam resultar de laços de vizinhança, de relações de parentesco, mas também de solidariedades e cumplicidades várias, assentes em juramentos de fidelidade. Os exércitos carolíngios parecem ter sido muito eficazes na articulação entre estas unidades táticas, que reuniam membros da Casa Real, jovens guerreiros ou milícias locais, entre outros.

Também não sabemos bem se os cavaleiros eram claramente separados dos peões, embora pareça provável que assim acontecesse. Em Rimini (no norte de Itália, em 553 ou 554), contra os Bizantinos do famoso general Narsés, os Francos colocaram os peões ao centro e os cavaleiros nas alas (à maneira romana). Mas, outras vezes, os cavaleiros devem ter ocupado uma posição central e, provavelmente, à frente do resto do dispositivo, tirando partido da sua maior mobilidade e de um melhor equipamento.

Existem alguns indícios da organização de "cunhas" (isto é, de formações táticas em forma de triângulo, com o vértice apontado para um ponto selecionado da linha inimiga), mas aqui corremos o risco de ser enganados pelo hábito de os cronistas recorrerem à terminologia clássica (cuneus). 


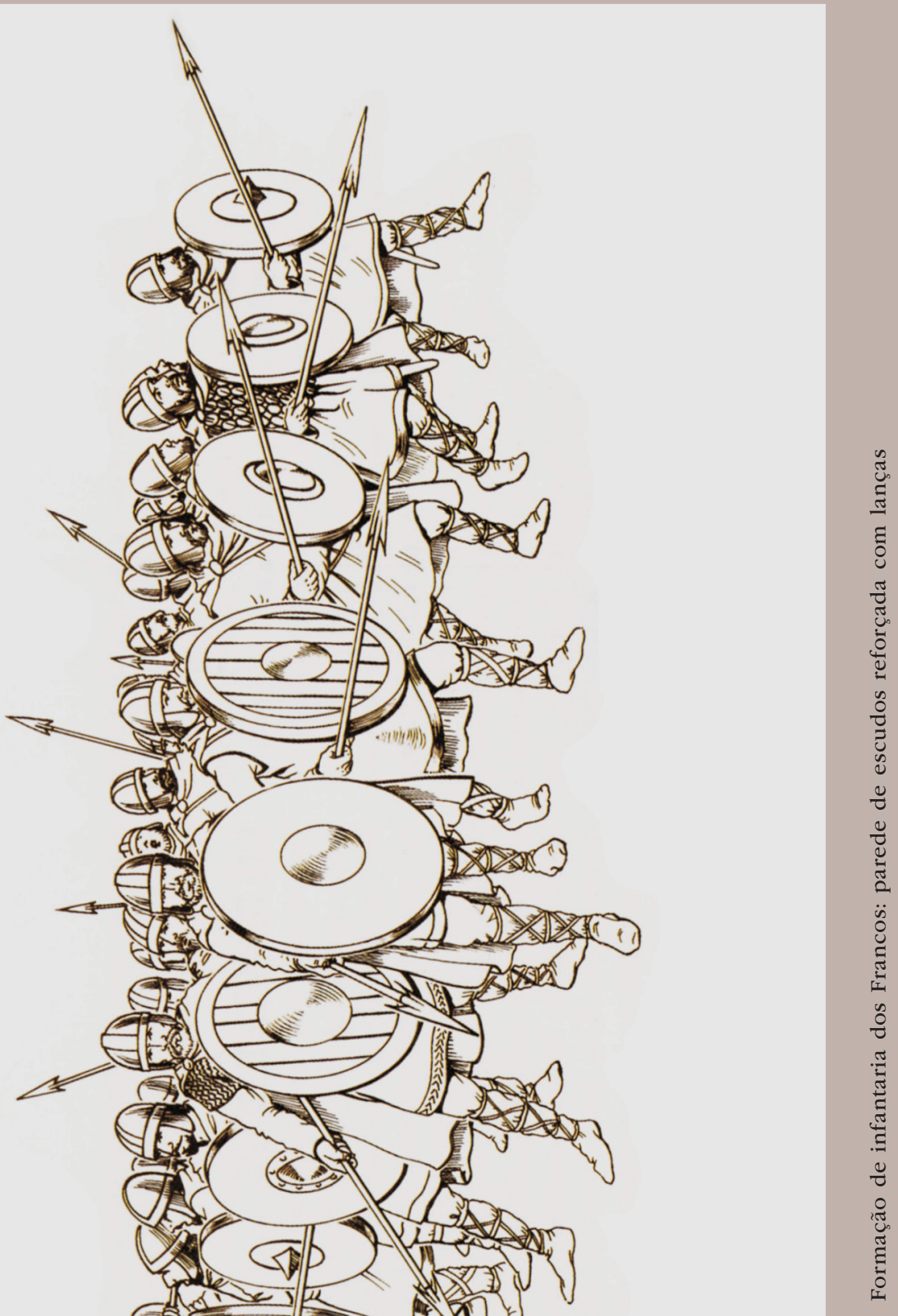


Ainda assim, Agátias diz que, na batalha de Casilinum, em 554, a frente da linha franca adotou a forma de uma "cabeça de javali" (tipo cunha), com a qual carregou sobre o elo fraco da linha bizantina.

Quando chegava a hora da verdade, uma formação densa de cavalaria ou de infantaria avançava devagar contra o seu adversário. A pé, o andamento devia ser cadenciado, às vezes com o auxílio de canções, parando-se de vez em quando para endireitar a linha. Caso se precipitassem, os riscos eram imediatos. No combate travado em 782 nas montanhas de Süntel, contra os Saxões de Widukind, a força expedicionária franca, liderada por três oficiais de Carlos Magno, acelerou em demasia e deitou tudo a perder: explicam os Anais do Reino dos Francos Revistos que os Gauleses agiram como se a sua missão consistisse em perseguir um inimigo em fuga e em tomar despojos, e não em enfrentar um adversário disposto em boa ordem para lhes fazer frente; assim, uma vez que a aproximação não tinha corrido bem, a batalha em si correu ainda pior, e os Francos foram massacrados quase até ao último homem...

Antes do 'encaixe' das formações uma na outra para o corpo a corpo com espada, podia haver lugar ao arremesso de lanças e, por vezes, de flechas. O poema épico Waltharius, de inícios do séc. x e que recria as façanhas de um filho do governador visigodo da Aquitânia que se notabilizou no séc. v, relata um combate de cavalaria em que as duas partes avançam cerradas e arremessam lanças uma contra a outra antes do choque. Nesse momento dramático, o campo de batalha faria decerto eco de um imenso ruído, resultante dos insultos, dos gritos de guerra e do som das trombetas e dos cornos, que assinalavam a entrada dos guerreiros nesse palco supremo das mortes cruéis, das mutilações, das dores horríveis, dos terrores e das raivas, e também dos atos de grande bravura e generosidade, ou de grande covardia e egoísmo.

No seio da falange, e tal como entre os hoplitas (recorde-se o que sobre eles dissemos no capítulo sobre Gaugamela), a ordem seria para encostar bem, em especial à direita, para tirar partido do escudo do companheiro. O objetivo principal consistia em pressionar a linha adversária no sentido de abrir rapidamente uma brecha e de a explorar, manejando as armas curtas. Tentava-se espetar ou cortar o adversário direto por cima dos escudos, visando a cabeça, o pescoço ou os ombros. Para os cavaleiros, o esforço ia 
no sentido de desmontar os inimigos, prostrando-os semi-inconscientes no chão. É possível que, numa fase inicial, se pudesse recorrer ao disparo de projéteis a partir do interior das "paredes de escudos" (ex.: uma pequena força de cavalaria estacionada como reserva nas fileiras de trás podia usar o seu arco e disparar por cima da cabeça dos seus aliados), mas não existem provas disso e convém frisar que, nas batalhas da Alta Idade Média, não há referências a arqueiros ligeiros a cavalo.

O tempo de combate entre duas forças organizadas em formação compacta era muito variável. Tudo dependia do número de efetivos, do seu treino, da sua disciplina, do seu equipamento e da sua resistência. Os comandantes pouco podiam fazer para além de, com a preciosa ajuda dos porta-estandartes, explorar as brechas que o adversário tinha sido obrigado a abrir, ou, ao contrário, colmatar as das suas próprias linhas. Não é, por isso, provável que os generais ocupassem uma posição recuada no terreno, onde a sua influência seria menor, para além da postura menos heroica. Podia haver lugar ao uso de reservas, sim, mas era preciso que o volume de efetivos fosse elevado: é que uma sangria de bons homens de armas podia comprometer a prestação do corpo principal.

Sabemos de batalhas que foram muito rápidas, como a notável vitória de Clóvis em Vouillé, mas também de outras que demoraram muitas horas ou mesmo mais do que um dia. Estão neste último caso os combates que envolviam povos cuja cultura bélica assentava em procedimentos táticos do tipo 'bate e foge', acumulando sucessivas escaramuças de pequena escala, como sucedia com os Ávaros, com os Bretões, com os Pictos ou com os Saxões. Nos 'casos padrão', havia sempre a possibilidade de o adversário, aterrorizado pela visão dos inimigos, fugir antes do contacto ou ceder terreno rapidamente. Se tal não acontecia, havia que porfiar, tentar romper e, depois, atacar os flancos interiores do adversário e as suas linhas mais recuadas a partir de trás. Era também nesta fase que se tornava mais fácil executar manobras de flanqueamento, pois nessa altura já havia tropas libertas de opositores, que podiam entregar-se a uma tal tarefa. Em condições normais, os exércitos dispunham-se face a face e ataques de flanco logo de início eram praticamente impossíveis, a não ser com recurso a forças emboscadas nas redondezas, como fez um exército escandinavo numa batalha travada na Nortúmbria já depois do ano 900. 
Quando a pressão do inimigo era grande, valia mais recuar para consolidar a linha do que desfazer a frente contínua. Claro que não era fácil a uma falange andar para trás, mas, por outro lado, o adversário, se quisesse progredir, teria então de o fazer passando por cima dos corpos dos inimigos derrubados, o que também era difícil. Era nestes momentos que se via a capacidade dos bons líderes, que teriam ainda de estar atentos a um outro risco: a fuga simulada dos adversários. Parece que os Francos do séc. VI foram algo vulneráveis a este estratagema, que consistia em induzir o adversário na convicção de que já não era possível aguentá-lo mais e em bater em retirada, suscitando uma perseguição descuidada; depois, mais à frente, dava-se ordem para parar, agrupar e contra-atacar um inimigo supostamente vencedor mas desunido e eufórico, totalmente apanhado de surpresa! Foi assim que os Francos perderam a batalha de Rimini e um outro combate na Septimânia, contra os Visigodos, em 589. Sublinhe-se, porém, que uma fuga simulada tinha também os seus perigos: precisava de ser muito bem coordenada e, de preferência, devia contar com o apoio de uma força de reserva, pois corria-se o risco de o adversário alcançar os 'fugitivos' e de a pretensa fuga se tornar real....

Esgotados todos os recursos, ganhava quem tinha mais resistência para gerir as fases de impasse em batalhas muito renhidas, mais ânimo para retomar as operações quando voltava a haver forças para encostar de novo as linhas, capacidade para matar maior número de adversários, mais disciplina para não cair na tentação de perseguir (ou de saquear) antes do tempo. Quando se tinha mesmo de fugir, os riscos eram tremendos: as maiores chacinas ocorriam durante as perseguições, quando se golpeava sucessivamente os homens tombados para se ter a certeza de que não voltariam a erguer-se, e quando os ânimos estavam mais quentes e o desejo de vingar a morte dos amigos estava mais acirrado. Mais valia ser feito prisioneiro no dia seguinte, quando a calma começava, lentamente, a regressar! O cemitério (não datado) de Eclles, no Kent, sugere ferimentos fatais na cabeça provocados pela luta cerrada, contrastando com os múltiplos ferimentos em diversas partes do corpo infligidos durante a perseguição. Não temos de que nos espantar: quem fugia estava de costas, muitas vezes desarmado, debilitado por golpes recebidos durante o combate, quase sempre exausto 
(física e psicologicamente) e frequentemente desorientado num território que não conhecia bem...

Não é possível estimar com exatidão as baixas nestas batalhas ferozes, mas parece seguro que, entre os vencedores, elas se traduziam sobretudo em feridos e em incapacitados e, entre os vencidos, em mortos em número bastante elevado. Muitos líderes foram abatidos durante as batalhas da Alta Idade Média: na Inglaterra anglo-saxónica do séc. VII, em 12 das 22 batalhas registadas morreu pelo menos um rei; em Ashdown, os Vikings perderam pelo menos seis chefes; e na batalha em que morreu o cronista Nitardo, ele próprio neto de Carlos Magno (abatido no Angoumois, em 844), faleceram também outros aristocratas de topo. Quem ficava prisioneiro podia ter destinos diversos: ser executado, ser libertado mediante o pagamento de um resgate, ser vendido como escravo ou até ser alistado na hoste vencedora. Tudo dependia da adrenalina do momento, das circunstâncias políticas e da cultura do exército vitorioso. Exército esse que nem sempre conseguia rentabilizar politicamente as suas vitórias no campo de batalha (ex.: Fontenoy ou Ashdown), mas que nunca deixava de tirar proveito do ordálio, saqueando avidamente o acampamento inimigo. O suor da luta lavava-se então na alegria da captura dos tesouros, das armas e dos seus preciosos ornamentos, dos arreios das melhores montadas e de um sem-número de outros proventos, que ajudavam a tornar a guerra uma atividade quase endémica na Europa de então.

\section{A batalha de Poitiers}

Meados de outubro de 732. O exército muçulmano comandado por Abd al-Rahman, em marcha para norte, para a cidade de Tours, é surpreendido perto de Poitiers por uma volumosa hoste liderada pelo dux Francorum, Carlos Martel, que viera em socorro do duque Eudo da Aquitânia.

Para tirar partido do fator surpresa e evitar a retirada do adversário, Martel optara talvez por circular por estradas secundárias até ficar face a face com o inimigo. O chefe incontestado dos Francos ambicionava travar aquele combate, pois sabia que isso era essencial para libertar o vasto e rico 
ducado da Aquitânia da ameaça muçulmana e para manter viva a chama do projeto de consolidar um reino franco a estender-se até ao Mediterrâneo. Se realmente era assim, o plano parece ter resultado, pois tudo indica que os muçulmanos foram realmente apanhados de surpresa, sinal de um fraco trabalho de scouting ao longo dos últimos dias antes da batalha.

O 'encontro' dos dois exércitos, porém, não precipitou a batalha. Durante nada menos do que uma semana, as hostes observaram-se mutuamente e ponderaram a aposta num combate decisivo. Do lado dos Francos, a opção era clara: Carlos Martel viera para travar batalha e escolhera o terreno de combate, ocupando o topo de uma colina razoavelmente arborizada. Dispunha de um exército numeroso, cujo núcleo duro era formado por tropas da Casa Real e dos séquitos de grandes magnates ligados a Carlos por laços de fidelidade, por companheirismo de armas e por interesses políticos e económicos. Não era um exército permanente e profissional, mas eram tropas calejadas, que há muito acompanhavam Martel nas suas sucessivas campanhas de dominação do regnum Francorum. Não temos meios para estimar com rigor o tamanho de uma tal hoste, mas não devia ser inferior a 10000 homens, tendo em conta a delicadeza da operação e a junção de forças com o duque Eudo da Aquitânia. Muitas destas tropas estavam montadas, mas a opção do chefe franco recairia numa formação apeada, à maneira de falange. Tanto quanto sabemos, Carlos nada fez, ao longo dos seis ou sete dias de espera no campo de batalha, para negociar com Abd al-Rahman. Os Francos estavam ali para vencer ou morrer.

Do lado muçulmano, as decisões eram bem mais difíceis de tomar, e só isso explica a enorme demora no início do combate. Abd al-Rahman estava interessado em devastar a Aquitânia, castigando Eudo pelo apoio que este prestara ao seu rival Munnus. Queria acumular despojos, semear o terror, criar condições para uma progressão futura dos muçulmanos (já posicionados na região pirenaica) até à foz do rio Garona. Mas dar batalha era subir muito a parada, era um risco que tinha de ser bem avaliado, até porque Martel tinha fama de ser um grande comandante e 'jogava em casa'. Ao mesmo tempo, Abd al-Rahman confiava nos seus homens, animados por sucessos recentes. E, sobretudo, não tinha grandes alternativas. Se optasse por uma retirada em boa ordem, de regresso à Septimânia, pagaria um 
preço elevado: por um lado, Carlos Martel receberia todo o crédito por ter repelido o adversário e por ter, dessa forma, salvado a cidade de Tours e o relicário de São Martinho, o "santo patrono da Gália"; por outro, o dux Francorum não deixaria de lançar sucessivos raides contra o trem de apoio muçulmano em retirada, enriquecendo os soldados francos, envergonhando a coluna árabe e berbere e pondo em causa o resultado de várias semanas de despojos acumulados durante a até aí vitoriosa incursão muçulmana pela Aquitânia.

Em síntese, Abd al-Rahman tinha de travar batalha, e até mais do que isso: convinha que aniquilasse o seu inimigo para que ele não pudesse depois sabotar a sua linha de marcha no regresso ao sul. A opção tinha os seus riscos, mas era inevitável e, de qualquer modo, Abd al-Rahman tinha alguns trunfos para jogar. Embora a sua hoste fosse provavelmente menos numerosa do que a de Martel, era forte em cavalaria (talvez 30\% do conjunto das tropas) e também muito experiente, e estava além disso moralizada e disposta a defender com unhas e dentes o valioso saque que o seu trem de apoio já abrigava. Em termos de equipamento, o exército de Abd al-Rahman também não ficava aquém do seu adversário. Em 732, exatamente um século após a morte de Maomé, os exércitos muçulmanos não eram propriamente uma 'ralé nómada' de infantaria berbere armada de forma fruste: o Oriente era então muito mais rico do que o Ocidente, e os muçulmanos tinham, entretanto, conquistado as regiões mais prósperas do Império Bizantino e tinham-se apoderado também dos recursos do Império Persa; os soldados muçulmanos, largamente recrutados nas regiões que tinham sido gradualmente conquistadas (Síria, Egito, Norte de África, Península Ibérica), eram, em geral, bem pagos e dispunham de armaduras de corpo, de elmos e de boas armas afiadas. Por isso, se o desafio era grande, Abd al-Rahman acreditava que poderia superá-lo.

Sábado, 25 de outubro: Carlos Martel dispõe os seus homens para um combate decisivo. Manda a quase totalidade dos seus cavaleiros desmontar e juntar-se às tropas apeadas. Com uns e com outros, forma então, no cimo da colina, um dispositivo em semicírculo (ou em quadrado), extremamente cerrado. No fundo, trata-se de uma falange, com os homens bem encostados uns aos outros e munidos de duas armas principais: um escudo grande, 
redondo ou oval, e espadas curtas, do género do gladius hispano-romano ou do scramasax, próprias para o combate corpo a corpo. No interior do dispositivo, Martel coloca algumas unidades de reserva, para o caso de o inimigo conseguir romper a formação principal e começar a atacar os flancos interiores ou mesmo a retaguarda da infantaria franca. É possível que, mais atrás, Martel tenha disposto ainda algumas tropas a cavalo, prevenindo assim a possibilidade de uma manobra de envolvimento muçulmana, o que não era nada provável - dada até a relação de forças no campo de batalha -, mas que, a ocorrer, se tornaria perigosíssima.

Do lado contrário, Abd al-Rahman apostou forte na sua cavalaria e nos atiradores com arco. Ao ver os Francos totalmente entregues a uma batalha defensiva, al-Rahman, líder experiente, deve ter começado por tirar partido da sua capacidade de tiro à distância. Os muçulmanos dispunham do poderoso arco composto recurvado, feito de várias camadas de osso, chifre e madeira, que podia ser utilizado também a cavalo e que tinha um alcance superior a 200 metros e bastante eficácia de tiro. Nas mãos de um guerreiro experiente, e desde que não acusasse os efeitos da humidade, era uma arma preciosa para desorganizar a falange adversária: poderia abrir as primeiras brechas, por onde penetraria depois a carga da cavalaria muçulmana, armada de lança e espada e apoiada por uma infantaria ligeira bastante móvel e adequada ao combate corpo a corpo.

Centenas ou milhares de flechas muçulmanas devem então ter zumbido pelos ares, criando uma atmosfera de tensão e de terror, que constituiu uma primeira prova de fogo para os homens de Carlos Martel. Era preciso aguentar firme, e autores como Bernard Bachrach sustentam que isso pode ter sido feito usando um dispositivo de origem romana bastante conhecido na Alta Idade Média: a célebre testudo ou "tartaruga", em que os combatentes dispunham os seus escudos por cima da cabeça e nas partes frontal e laterais da sua formação, para evitar a penetração dos mísseis adversários. Não sabemos se, além disto, houve alguma réplica de tiro por parte dos Francos, que também dispunham de arcos, embora mais simples e de menor alcance. Se houve, pode ter sido protagonizada pelo pequeno núcleo de cavalaria franca eventualmente colocado na retaguarda, 


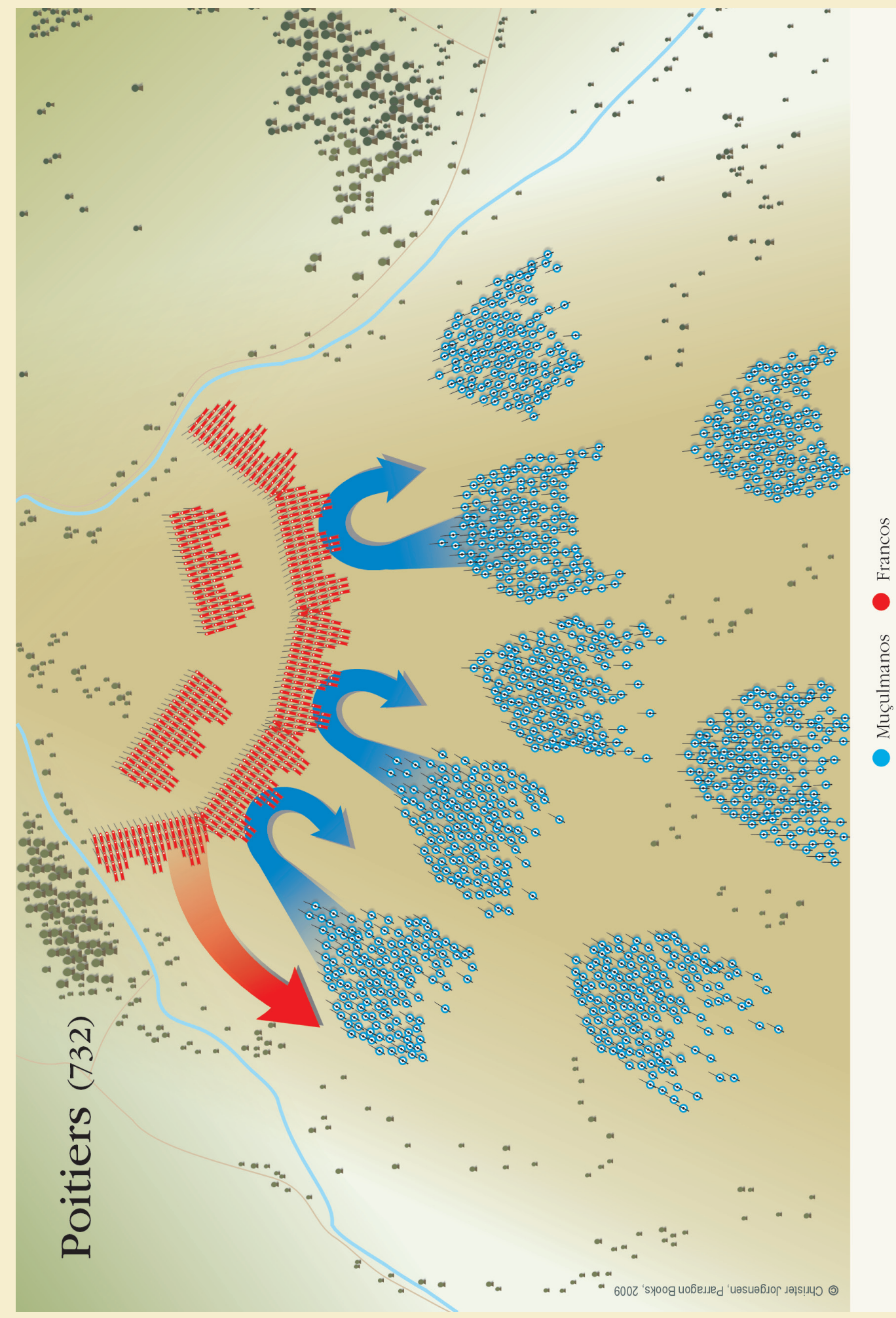


com esses cavaleiros a dispararem as suas flechas por cima das cabeças dos seus próprios companheiros (como se sabe, o disparo com arco é muitas vezes feito para cima, em volley, e não em tiro tenso e horizontal). Certo é que, tal como está documentado para o combate de Rimini, os Francos superaram este primeiro teste, e a sua formação não se desorganizou.

Neste ponto, Abd al-Rahman terá dado indicação para o início das cargas da cavalaria muçulmana. Porventura recebidas com arremesso de lanças, estas prolongaram-se durante bastante tempo, talvez durante horas, pois a Crónica de 754 (a nossa principal fonte para o combate de 25 de outubro) diz que a batalha terminou já ao cair da noite, o que, nessa altura do ano, corresponde às $19 \mathrm{~h}$ solares, aproximadamente. Ora, foi aqui que tudo se decidiu. As fontes salientam a extraordinária coesão da falange de infantaria franca e a mesma crónica refere até, numa frase que ficou famosa, que os "Nortistas", ou seja, os Francos, "permaneceram imóveis como uma parede de escudos, mantendo-se unidos como um glaciar nas regiões frias"!

Ou seja, os homens de Martel não só não cederam terreno como não se desorganizaram. Se a falange abriu alguma brecha e permitiu a penetração de um ou outro pequeno corpo de cavalaria muçulmana, o problema foi resolvido pelas unidades colocadas em segunda linha. Ao fim de muita insistência vã, colina acima, o cansaço começou a apoderar-se das tropas de Abd al-Rahman. E o cenário agravar-se-ia quando, aproveitando a fraca vigilância e o excesso de confiança dos muçulmanos, alguns batedores francos conseguiram alcançar o acampamento inimigo. Libertaram os prisioneiros aquitanos e lançaram alguma confusão na hoste adversária. Nessa altura, parece que parte da retaguarda muçulmana, ao aperceber-se disso e receando perder o seu rico despojo, começou a recuar. Os ataques ao dispositivo de Martel enfraqueceram e o facto levou Abd al-Rahman, que provavelmente liderava a ofensiva, a vir atrás para estancar aquele movimento de recuo e para incentivar os seus homens a retomar a luta na linha da frente. Porém, talvez por ter acudido sem o apoio da sua guarda pessoal, al-Rahman foi trespassado pelas lanças dos cristãos e isso constituiu um verdadeiro golpe de misericórdia nas aspirações muçulmanas: com o seu líder morto e a respetiva bandeira abatida, as tropas desuniram-se e bateram em retirada. 
Aqui, devemos sublinhar a grande capacidade de comando de Martel, que conseguiu manter os seus homens em boa formação e travar o seu inevitável instinto de perseguição. Isto só foi possível graças a muito treino e disciplina, pois era sempre muito difícil a um exército da época anterior à pólvora manter a sua posição estática no terreno durante muito tempo, para mais diante de um inimigo em fuga. Vários estudiosos da arte da guerra têm salientado o "frenesi de matar", que se apodera dos homens quando veem os seus adversários em debandada: como notou Verbruggen, uma unidade militar é sempre uma 'plebe' à espera de uma oportunidade para escapar à disciplina que a criou... Ainda assim, a "parede gelada de escudos" manteve-se unida e não arriscou perseguir, com a noite a cair e sem se saber se os muçulmanos teriam capacidade para reagrupar, ou se estariam até a executar uma daquelas manobras de fuga simulada, que já tantas vezes haviam comprometido as aspirações dos Francos.

Domingo, 26 de outubro: depois de uma noite vigilante, Carlos Martel, logo de madrugada, iniciou a marcha do exército vitorioso em direção ao acampamento inimigo, cuja localização exata desconhecemos. Para este segundo dia, a nossa melhor fonte é a Continuação de Fredegário, pois o anónimo da Crónica de 754 nega a existência de mais qualquer combate. O exército franco deve ter formado uma coluna relativamente larga e profunda, tirando partido da boa estrada romana que corria de norte para sul, entre Tours e Poitiers. Ao chegar às proximidades do acampamento inimigo, Carlos mandou parar as tropas e proceder a um reconhecimento do local, através de batedores do terreno. Ele queria preparar bem o assalto final e conhecer em pormenor a organização do arraial muçulmano, repleto de tendas e pavilhões distribuídos em alinhamentos esmerados. Assim que os batedores regressaram, Martel dispôs as suas tropas numa comprida formação em linha e comandou pessoalmente a investida. O cronista explica que os Francos irromperam pelo acampamento muçulmano e rapidamente o tomaram de assalto, derrubando as tendas montadas dentro do circuito fortificado e ocupando as posições-chave, de acordo com a sinalização prévia dos seus batedores. Provavelmente, devido às baixas sofridas no 
combate do dia anterior, haveria zonas do arraial menos bem defendidas. $\mathrm{O}$ ataque foi, portanto, bem-sucedido e originou um verdadeiro massacre.

Os muçulmanos que conseguiram escapar foram poupados, pois Martel, mais uma vez, optou por não os perseguir, já que não dispunha de informação pormenorizada sobre a zona a sul de Poitiers, nem de tropas repousadas para empenhar em cavalgadas temerárias, nem sequer de um trem de apoio bem abastecido e com mobilidade suficiente para apoiar uma tal manobra. Terminava aqui, com um estrondoso sucesso, a operação de Carlos Martel para a salvação da Aquitânia.

\section{Depois da batalha}

A vitória de Carlos Martel em Poitiers e a aniquilação do exército de Abd al-Rahman travaram as ambições muçulmanas no sudoeste da Gália e contribuíram para a extensão do domínio cristão até ao Mediterrâneo. Durante muitos anos, a historiografia sobrevalorizou a vitória dos Francos e o seu papel na 'salvação' da cristandade. Os muçulmanos tinham mais possessões no sul da Gália, que mantiveram durante algum tempo, e Carlos Martel até obteve outras vitórias interessantes na mesma época.

Ainda assim, depois da derrota averbada em Poitiers, as aspirações muçulmanas na Gália ocidental esfriaram e os muçulmanos concentraram-se no sudeste, tendo Yusuf ibn Abd al-Rahman, governador de Narbonne, capturado Arles (em 734) e Avinhão. Carlos Martel reagiu e libertou ambas as cidades em 737. No mesmo ano, cercou Narbonne, tendo vencido os muçulmanos nas redondezas da cidade. Em 738-739, os muçulmanos, talvez com o apoio do $d u x$ de Marselha, o cristão Mauronto, iniciaram outra ofensiva, o que obrigou Martel a ripostar, tendo Avinhão sido outra vez libertada, em 739. Então, contando com a promessa de auxílio de Liutprando, o rei dos Lombardos, e depois de quebrar a colaboração entre a nobreza local e os muçulmanos, o líder dos Francos recuperou o controlo sobre a Provença. A partir de 751, o sucessor de Carlos Martel, Pepino III, "o Breve", completaria o affaire provençal e reconquistaria Narbonne. Desde essa altura, os muçulmanos ficaram confinados à Península Ibérica. 
A vitória de Carlos Martel em Poitiers permitiu-lhe ainda estabelecer com sucesso a supremacia franca sobre a Aquitânia; em 735, à morte do duque Eudo, os seus filhos Hunoaldo e Hatto tiveram de lhe jurar fidelidade. Carlos não desejava retirar aos sucessores de Eudo o ofício de $d u x$ (nas mãos da família há várias gerações), mas exigiu que o dux Aquitanorum lhe ficasse submetido. A sua estratégia era conseguir o controlo de todo o regnum Francorum, mas admitia a existência de estatutos especiais em alguns principados. Ao mesmo tempo, fiel ao seu objetivo principal, Carlos resistiu sempre a qualquer tentação de intervir na Península Ibérica.

Quando o rei merovíngio, Thierry IV, morreu, em 737, não foi substituído, pois Carlos Martel permaneceu como dux Francorum e nunca quis ser rei! Deste modo, entre 737 e 741 não existiu nenhum rei dos Francos. Apesar disso, quando Martel faleceu, em 741, já ninguém duvidava que a sua dinastia se tinha imposto de vez. A unidade cultural e económica do Ocidente estava em marcha, só faltava mesmo a unidade política, que chegaria em breve com os reis carolingios, descendentes de Carlos Martel.

Entre 741 e 747, Pepino "o Breve", filho de Carlos Martel e de Swanahilda, exerceu o cargo de prefeito do palácio da Nêustria, enquanto o seu meio-irmão, Carlomano, se tornou prefeito da Austrásia. Não foram fáceis os primeiros anos: a oposição da aristocracia franca, arreigada ao poder mágico dos reis cabeludos, era forte, e, em 743, os príncipes germânicos e aquitanos, revoltados, decidiram restabelecer no trono um rei merovíngio - Childerico III. Mas Pepino soube tirar partido do sistema de fidelidades e recompensas vassálicas preparado por Carlos Martel e, em aliança com o irmão Carlomano, obteve vitórias militares na Baviera, na Aquitânia e na Alamânia.

Em 747, Carlomano entrou para a abadia de Monte Cassino e Pepino "o Breve" partiu para a conquista do título real. O rei Childerico III foi afastado com a caução do papa Zacarias e, em Soissons, em novembro de 751, Pepino III foi eleito rei e foi ungido e coroado pelo bispo Bonifácio. Em 754, teria lugar uma nova sagração do primeiro rei carolíngio, desta feita pelo papa Estêvão III, completada pela unção de Carlos Magno e de seu irmão Carlomano, filhos de Pepino "o Breve" e de sua esposa Bertrade. Estava estabelecida a hereditariedade real dinástica, ao mesmo tempo que 
se firmava a união das duas monarquias: a eclesiástica e a régia. Pepino III foi designado "patrício dos Romanos" e converteu-se no protetor do papado contra a ameaça dos Lombardos.

Com Pepino "o Breve", o reino franco tornou-se o espaço político da Cristandade no Ocidente, frente a uma Península Ibérica ocupada pelos muçulmanos e frente a Bizâncio, mais centrada sobre a Ásia Menor e agitada pela questão religiosa das imagens. Ainda que estivesse longe de ser o mais brilhante do ponto de vista cultural, o reino dos Francos impunha-se pela sua unidade, pela sua aliança com a Igreja e pelo seu controlo de um espaço nórdico em progressiva expansão.

Carlos Magno, rei a partir de 768, transformaria o reino dos Francos num imenso território, habitado por cinco a oito milhões de pessoas, e onde podemos hoje reconhecer uma dúzia e meia de países europeus! Faltava apenas a cereja no topo do bolo, ou seja, a elevação do regnum Francorum a uma dignidade semelhante à do Império Romano do Ocidente. A Igreja colaborou no projeto e a cerimónia veio a ter lugar no Natal de 800, na Basílica de São Pedro, em Roma: "Carlos Augusto” foi "coroado por Deus grande e pacífico imperador dos Romanos", desejando-se-lhe "vida e vitória!". Foi, claro está, um êxito tremendo. O papa Adriano I chamaria então ao rei carolíngio "magnus rex", de onde veio a resultar o nosso "Carlos Magno".

Estava recriado, em versão bárbara e nórdica, o Império Romano do Ocidente. E, com isso, começava a cair o pano sobre a primeira fase da Alta Idade Média. Em breve, novos protagonistas - Normandos, Sarracenos e Magiares - viriam pôr em causa aquilo que Merovíngios e Carolíngios tinham construído. Os Normandos colocariam problemas muito delicados, que conduziram ao Tratado de Saint-Clair-sur-Epte, firmado em 911. Neste, o carolíngio Carlos "o Simples" (herdeiro de uma das três partes em que o império de Carlos Magno fora dividido em 843) reconheceu a um dos chefes dos Vikings o direito a ocupar a Normandia, uma das regiões mais ricas de toda a Gália. A partir dessas prósperas terras, via-se bem o mar que separa a França da Inglaterra. Dentro de um século e meio, os destinos dos dois reinos cruzar-se-iam, pois em 1066 os Normandos embarcaram para atravessar o Canal da Mancha e atacar a Inglaterra. Foi na batalha de Hastings, talvez o combate mais importante de toda a Idade Média europeia... 


\section{Fontes principais}

Charlemagne: translated sources. Edited by P. D. King. Lancaster, University of Lancaster, Central Print Unit, 1987.

"Chronicle of 754": K. Baxter Wolf (transl.), in Conquerors and Chroniclers of Early Medieval Spain. Liverpool, 1990.

The Fourth Book of the Chronicle of Fredegar and its Continuations: J. M. Wallace-Hadrill (ed. and transl.). Oxford, 1960.

\section{Leituras recomendadas}

Bernard S. Bachrach, Early Carolingian Warfare. Prelude to Empire. Filadélfia, University of Philadelphia Press, 2001.

Christer Jorgensen (general editor), Great Battles. Bath-Nova Iorque-Singapura-Hong Kong-Colónia-Deli-Melbourne, Parragon Books, 2009 (ed. orig.: 2007).

Claude Gauvard, La France au Moyen Âge, du Vème au XVème siècle. 3. ${ }^{a}$ ed., revista, Paris, P.U.F., 1999 (ed. orig.: 1996).

Guy Halsall, Warfare and Society in the Barbarian West, 450-900. Londres-Nova Iorque, Routledge, 2003.

Hans-Henning Kortüm, in Clifford J. Rogers (editor in chief), The Oxford Encyclopedia of Medieval Warfare and Military Technology, Oxford University Press, 2010, 3 vols. (vide: "Charles Martel", vol. 1, pp. 363-364; "Franks, Merovingian", vol. 2, pp. 123-133; "Tours, Battle of", vol. 3, pp. 370-371).

J. F. Verbruggen, "The Role of Cavalry in Medieval Warfare", in Journal of Medieval Military History, vol. III, 2005, pp. 62-71 (translated by Kelly DeVries). 
(Página deixada propositadamente em branco) 


\section{CAPÍTULO 5}

\section{HASTINGS (1066): A CONQUISTA DE INGLATERRA - UM DIA PARA MUDAR A EUROPA}

\section{Significado e Fontes}

A batalha de Hastings, em que se enfrentaram o rei de Inglaterra, Haroldo II Godwinson, e o duque da Normandia, Guilherme II, é considerada a batalha mais importante de toda a história medieval europeia. A justo título, diga-se desde já. Do ponto de vista militar, ela pôs em confronto uma das melhores infantarias da época (a anglo-saxónica) e a melhor cavalaria que a Europa já conhecera desde o tempo dos primeiros Carolíngios (a cavalaria normanda). Do ponto de vista político, nenhuma batalha iguala Hastings em significado, tanto pelas suas consequências imediatas como pelos seus efeitos a longo prazo. A batalha de 14 de outubro de 1066 mudou a Inglaterra, a França e a cristandade latina de uma forma geral. Depois de Hastings, nada ficou como dantes.

Esta é, por tudo isso, uma das batalhas medievais que, de há séculos, mais tem interessado os historiadores. Foram escritas dezenas de artigos e de livros acerca de Hastings 1066. A própria batalha é relatada por uma quantidade invulgar de fontes escritas, várias delas coevas, e ainda por um documento iconográfico sem paralelo no mundo: a Tapeçaria de Bayeux. Conhecemos o campo de batalha, onde foram realizados trabalhos de investigação e onde foi construída, pouco tempo depois do combate, a magnífica abadia de Battle. E, no entanto, a reconstituição da peleja permanece cheia 
de interrogações. Sabemos a data, sabemos o local, conhecemos o enquadramento político e militar em que se formaram e movimentaram os exércitos anglo-saxónico e normando, sabemos quem venceu a batalha e suspeitamos porquê. Contudo, o nosso conhecimento profundo e pormenorizado das circunstâncias e peripécias da campanha deixa muito a desejar, de tal maneira que podemos dizer que não existe ainda nenhuma reconstituição satisfatória da batalha. Tentaremos, neste capítulo, aproximar-nos o mais possível desse objetivo.

O estudo da batalha de Hastings é iluminado por diversas fontes, o que não é nada vulgar em meados do séc. XI. A crónica de Guilherme de Poitiers é considerada a fonte principal. Falamos da Gesta Guillelmi ducis Normannorum et regis Anglorum ("Gesta de Guilherme, duque dos Normandos e rei dos Ingleses") composta entre 1071 e 1077, ou seja, muito poucos anos após os acontecimentos. Trata-se do mais extenso relato em prosa sobre a campanha de Hastings. O manuscrito original foi copiado e impresso por Duchesne em 1619, a partir de um único documento, danificado e incompleto. Mais tarde, o manuscrito desapareceu, possivelmente no incêndio de 1731 da Cottonian Library (a biblioteca privada de Sir Robert Bruce Cotton, o célebre antiquário e bibliófilo falecido em 1631, cuja coleção esteve na origem da British Library). Por isso, o prefácio e os capítulos derradeiros, que podiam conter informações sobre o autor, estão hoje perdidos e quase tudo o que se sabe sobre eles provém da História Eclesiástica, de Orderico Vital. Guilherme de Poitiers descendia de uma família nobre de Préaux, aparentada com os Beaumont; nasceu na Normandia cerca de 1028 (quase ao mesmo tempo que o duque Guilherme) e deve ter estudado em Poitiers. O seu conhecimento dos assuntos militares é evidente, pelo que deve ter tido instrução marcial enquanto jovem, podendo ter servido o duque como soldado ao longo desse período. Perto dos 30 anos, tornou-se clérigo, ao mesmo tempo que uma sua irmã se tornava abadessa; foi arquidiácono de Lisieux e mostra um bom domínio das leis. Pouco depois da conquista normanda, foi para Inglaterra e serviu Guilherme como capelão. Por isso, teve acesso fácil e frequente àqueles que participaram na campanha de Hastings, o que torna precioso o seu circunstanciado relato. A narrativa de Guilherme de Poitiers 
é, genericamente, fiável, embora tendenciosa: o autor é como que um 'porta-voz' do duque e escreve na qualidade de seu admirador entusiástico, adotando uma retórica heroica e modelos clássicos que denunciam a cultura do narrador. Para as ações e motivações específicas do lado anglo-saxónico, convém utilizar esta fonte com cuidado. O que temos hoje da narrativa de Guilherme de Poitiers prolonga-se até 1067, mas a sua Gesta foi utilizada (e, de certa maneira, preservada) até 1075, por Orderico Vital.

A segunda fonte escrita normanda mais importante é a Gesta Normannorum ducum ("Gesta dos Duques dos Normandos"), de Guilherme de Jumièges. Trata-se, neste caso, de uma história de todos os duques normandos, e não só de Guilherme. Esta obra deve também ter sido escrita por volta de 1070, constituindo a sua primeira parte quase uma cópia do trabalho de Dudon de Saint-Quentin, um clérigo da Picardia que viveu algum tempo na corte normanda e que faleceu antes de 1043. Jumièges era um grande mosteiro normando, com fortes ligações a Inglaterra, e este Guilherme era um monge, um homem sem treino militar e que escreveu de acordo com o ponto de vista dos conquistadores. É provável que o seu trabalho tenha tido uma difusão mais ampla do que o de Guilherme de Poitiers, uma vez que foi copiado e interpolado por diversos cronistas posteriores, em especial por Orderico Vital e por Roberto de Torigny (m. 1186).

A terceira fonte 'pró-normanda' é de natureza iconográfica e tem uma beleza excecional. Falamos da Tapeçaria de Bayeux, na realidade um bordado histórico que deve ter sido fabricado com vista à cerimónia de dedicação da catedral de Bayeux (na Normandia, perto de Caen), que teve lugar em 1077. Consiste em oito peças cosidas umas às outras, formando um conjunto com cerca de 50 centímetros de altura e com mais de 70 metros de comprimento! A tela de suporte é de linho branco e o bordado foi feito com fios de lã de diversas cores ou tons diferentes: as cinco cores principais são o vermelho-tijolo, o verde-azulado, o verde-claro, o castanho-amarelado e o azul-acinzentado; como cores subsidiárias, utilizou-se o verde-sálvia, o amarelo e um azul muito escuro (quase preto). No entanto, não podemos ter a certeza absoluta de que estas fossem as cores originais, embora elas sejam notavelmente vivas e o desenho permaneça muito nítido, também devido ao facto de a peça ter sido bem restaurada e valorizada. Um artista 
desenhou as cenas e, depois, os artesãos executaram o bordado utilizando ponto pé de flor (para os contornos e as letras) e ponto cheio para o resto. Para a maioria dos fundos ou para a representação da cor da pele das personagens, por exemplo, optou-se por manter a cor natural da tela (o linho branco).

A Tapeçaria de Bayeux, um trabalho que se enquadra num conjunto de obras do mesmo tipo datáveis da segunda metade do séc. XI, deve ter sido fabricada em Inglaterra, possivelmente em Canterbury (Cantuária, no extremo sudeste), onde existia uma grande escola de bordado decorativo cujas peças apresentam um estilo e uma técnica semelhantes. Além disso, diversos motivos exibidos na tapeçaria, em especial nos seus frisos superior e inferior, inspiram-se claramente em manuscritos anglo-saxónicos dos sécs. $\mathrm{X}$ e XI, muitos dos quais pertenciam à rica coleção da catedral de Canterbury. A vida e o movimento da peça são próprios da tradição anglo-saxónica, e também há nomes com uma grafia não francesa inscritos na legenda em latim que acompanha a descrição da campanha de Guilherme em Inglaterra. Pensa-se que a peça pode ter sido desenhada por um só autor, dada a sua extraordinária unidade, provavelmente um homem, devido ao realismo das cenas de batalha e dos equipamentos militares representados. Nesta peça fabulosa, podemos apreciar cerca de 50 cenas, relativas não só a combates mas também a caçadas, a construção naval, a navegação no alto-mar, a culinária, a cerimónias religiosas, a construção de castelos, entre outras. Os pormenores incluem, por exemplo, armas, arreios de cavalos, vestuário e relicários. São representadas 623 personagens, 202 cavalos, 55 cães, 505 outros animais (ursos, lobos, raposas, pássaros e animais fabulosos, por vezes em breves ilustrações de fábulas célebres, como a do corvo e da raposa, de Esopo), 37 edifícios, 41 navios e barcos e 49 árvores. Há ainda perto de 2000 letras (elegantíssimas, com perto de $2,5 \mathrm{~cm}$ de altura), as quais compõem legendas em latim, que acompanham e enriquecem toda a narrativa visual. Estas legendas foram minuciosamente estudadas por Paula Dias, que destacou, entre outros aspetos interessantes, a sua interação com as imagens, a sua simplicidade, as flutuações na ortografia e as dificuldades sentidas pelo autor na adaptação da fonética germânica dos nomes bárbaros à fonética romana. 
A narrativa da Tapeçaria de Bayeux principia em 1064 e prolonga-se até ao termo da batalha de Hastings, mas o bordado, infelizmente, está incompleto e termina bruscamente: estima-se que faltem dois ou três metros, que talvez representassem a coroação de Guilherme em Londres, tal como parece poder deduzir-se de versos de Baudry de Bourgueil (bispo de Dol-en-Bretagne entre 1107 e 1130, poeta e historiador latino e autor de um poema dedicado a Adélia da Normandia, uma das filhas de Guilherme "o Conquistador").

A tapeçaria comporta um corpo principal, ao centro, completado por dois pequenos frisos (superior e inferior) com motivos diversos e, por vezes, bastante enigmáticos. As cenas são separadas por árvores estilizadas ou por letras, e o artista recorre a diversos efeitos plásticos e a outros truques para compensar a ausência de perspetiva. Documento excecional para ilustrar o quotidiano do mundo medieval (hábitos, costumes, diversões), este bordado histórico, dotado de apreciável sentido crítico e de humor, consta do inventário de 1476 da pequena cidade normanda de Bayeux. Nos primeiros séculos, deve, portanto, ter estado exibido na sua sumptuosa catedral, enfeitando as paredes verticais, preso de coluna em coluna. É geralmente admitido que a tapeçaria terá sido feita por encomenda e sob os auspícios do bispo Odão de Bayeux, irmão de Guilherme e participante direto na batalha, decerto sob instigação do duque e para legitimar a causa normanda e glorificar a coragem, o heroísmo e o sentido de justiça do seu líder. Claro que não se tratava apenas de decorar uma igreja, mas também de contar uma história gloriosa (para os Normandos) aos muitos analfabetos que a visitavam; como observou Paula Dias, o Concílio de Arras, reunido em 1025, voltou a permitir e recomendou mesmo o uso das artes visuais nas igrejas, com o objetivo de educar os fiéis, em especial os iletrados. Neste caso, trata-se também de uma história com moral, pois, como veremos, os Normandos acreditavam que, ao ser coroado rei de Inglaterra, Haroldo II cometera perjúrio, recebendo depois, na batalha de Hastings, o castigo adequado...

Em 1792, em plena Revolução Francesa, a tapeçaria foi salva in extremis da destruição, quando alguns burgueses de Bayeux, que queriam lutar pela República, se preparavam para a utilizar como toldo de um carro que ia partir para Paris! Em 1803, suscitou o interesse de Napoleão (que queria conquistar 
a Inglaterra) e, em 1818, foi copiada para a Sociedade dos Antiquários de Londres, altura em que Charles Stothard a estudou com extrema minúcia (fios desaparecidos, marcas de agulha, por exemplo), o que seria precioso para o seu futuro restauro. Em 1870-71, quando o exército da Prússia ameaçava a Normandia, a valiosa tapeçaria foi escondida num reservatório de zinco e, nos inícios da Segunda Guerra Mundial, foi colocada num abrigo seguro, embora os Alemães tenham feito questão de a conhecer. Em junho de 1944, no "Dia D", seria transferida à pressa para as caves do Louvre, em Paris, por causa do desembarque das tropas aliadas na Normandia, que teve lugar em Arromanches, escassos $10 \mathrm{~km}$ a norte de Bayeux. A tapeçaria foi depois exposta na capital francesa, regressando mais tarde à terra de origem, ao antigo palácio episcopal e, desde 1983, a um lugar (o antigo seminário grande) que foi especialmente preparado para a acolher. Hoje, é a cidade de Bayeux que cuida da preservação da tapeçaria, que pode ser visitada no espaço museológico do Centre Guillaume le Conquérant. Muitos consideram esta peça a mais antiga banda desenhada do mundo! Por gentileza da bela cidade normanda, reproduzimos nove cenas deste bordado histórico, uma das melhores fontes iconográficas europeias de toda a Idade Média.

Do lado das fontes anglo-saxónicas, o destaque vai para a chamada Crónica Anglo-Saxónica. Trata-se de um conjunto de anais escritos em língua vernácula (isto é, em inglês antigo), aparentados entre si mas distintos, produzidos em diferentes centros monásticos. No fundo, são diversas versões de um trabalho iniciado ao tempo do rei Alfredo "o Grande" (871-899), sob a forma de anais, ou seja, de registos ano a ano, sem uma preocupação de sequência narrativa. A obra foi sofrendo acrescentos em diferentes mosteiros, o que gerou a existência de versões distintas. Na prática, uma casa religiosa pedia emprestada a versão de outra e depois interpolava, consoante a sua perspetiva e os seus interesses. Há cinco versões principais da Crónica Anglo-Saxónica (A, B, C, D e E), das quais sobreviveram três para o período entre 1042 e 1079 (a C, a D e a E); destas, a mais completa, no que diz respeito à conquista normanda, é a versão $\mathrm{D}$, cujo manuscrito apresenta uma caligrafia dos finais do séc. XI; as versões D e E derivam de uma versão feita em York e são idênticas até 1031; a partir daí, a versão D prossegue com interesses predominantes na região do Norte de Inglaterra (provavelmente 
alimentada em York), prolongando-se até 1079. Quanto à versão E, a partir de 1031 deve ter sido escrita no mosteiro de Peterborough (a sudeste de Lincoln), cujo abade Leofric surge expressamente mencionado por ocasião do seu decesso. Esta versão vai até mais tarde do que as outras: termina em 1154, com a morte do rei Estêvão de Blois e a ascensão de Henrique II, o primeiro monarca Plantageneta (1154-1189). Deste modo, as versões que mais nos interessam exprimem o ponto de vista da Inglaterra do norte e do leste, ou seja, das zonas de maior influência escandinava. Os seus autores eram monges beneditinos, que não tinham acesso aos contactos privilegiados de Guilherme de Poitiers. Como observou Stephen Morillo, a Crónica Anglo-Saxónica não pretende fornecer uma visão global, ou contar uma história unificada; os vários centros monásticos que alimentaram estes registos refletem os interesses locais dos lugares da sua composição. No entanto, trata-se, ainda assim, de uma fonte valiosa, pois exprime um ponto de vista anglo-saxónico, segundo o qual os acontecimentos de 1066 foram pouco menos do que calamitosos... O declínio do inglês como língua culta após a conquista normanda condenou a continuação da Crónica Anglo-Saxónica, cujas versões influenciaram cronistas latinos, como o monge de Worcester.

O Chronicon ex Chronicis é, como o nome latino indica, uma compilação de crónicas. O trabalho foi feito em Worcester (a noroeste de Oxford) por um monge chamado João de Worcester, falecido cerca de 1140 (ou por um seu antecessor, chamado Florêncio). Trata-se de uma história do mundo, que começa com a Criação e que termina em 1140. O quadro cronológico foi fornecido pela crónica de Mariano Escoto (m. 1082), mas uma grande quantidade de material, designadamente sobre a história inglesa, foi enxertada nele. O compilador deve ter usado, para o séc. XI, uma versão perdida da Crónica Anglo-Saxónica, traduzida para latim e composta com algum cuidado e preocupação de rigor. Esta circunstância fornece-nos um termo de comparação útil com aquela fonte, apresentando um ponto de vista contemporâneo dos acontecimentos de 1066, filtrado pela lente da adaptação anglo-saxónica que se seguiu à conquista normanda. Atendendo ao facto de João de Worcester ser expressamente apontado como o autor de duas entradas (para 1128 e 1138), de dois manuscritos terem sido escritos pela sua mão e de o cronista anglo-normando Orderico Vital o ter visto a 
trabalhar neste projeto (a mando de Wulfstan, bispo de Worcester), tomaremos João de Worcester (e não Florêncio) como o autor mais provável do Chronicon ex Chronicis. Este sobreviveu em cinco manuscritos e, para a sua compilação, foram também usadas obras de Beda "o Venerável” (673-735), de Asser (o biógrafo de Alfredo "o Grande"), de Guilherme de Malmesbury e algumas "Vidas de Santos", entre outros trabalhos.

Finalmente, o Carmen de Hastingae Proelio (a "Canção sobre a batalha de Hastings"). Trata-se de um longo e pormenorizado poema sobre a batalha, cujo manuscrito foi redescoberto em 1826 por G. H. Pertz. Configura, a seguir a Guilherme de Poitiers e à Tapeçaria de Bayeux, a terceira narrativa minuciosa da campanha e da grande batalha. Mas é também a mais problemática em termos de proveniência. Como resume Stephen Morillo, há duas posições quanto a esta fonte. A primeira é a de que se trata de uma obra do bispo Guido de Amiens, que a terá escrito antes de maio de 1068. A enigmática dedicatória ("L. ... W. ... salutat") poderia querer dizer "Lanfrancum Wido salutat" ("Guido saúda Lanfranc", arcebispo de Cantuária entre 1070 e 1089, amigo e conselheiro de Guilherme). Se assim for, trata-se de uma valiosa fonte coeva, que Guilherme de Poitiers terá usado ao escrever a sua Gesta. Note-se que Guido de Amiens foi um nobre importante, que viajou para Inglaterra (na companhia de Matilde, a esposa do duque Guilherme) dois anos após a batalha de Hastings; e Orderico Vital afirma que ele escreveu um poema sobre a batalha. A segunda posição, mais recente, defende que o Carmen foi composto depois (possivelmente bastante mais tarde, pois os manuscritos sobreviventes, um principal e outro tributário, oriundos de Trier, têm caligrafia de c. 1100), por um autor desconhecido. Neste caso, o Carmen derivaria tanto da Gesta de Guilherme de Poitiers como de outras tradições pouco fiáveis, pelo que não teria valor como fonte para o estudo dos acontecimentos de 1066. A comunidade científica ainda hesita, mas as dúvidas propostas pelos autores da segunda tese (R. H. C. Davis e seus seguidores) ainda não foram suficientemente convincentes para excluir o Carmen do cânone das fontes sobre a batalha de Hastings. Na verdade, se a atribuição a Guido de Amiens for correta, então o Carmen é um dos relatos mais próximos do evento, fornecendo-nos uma perspetiva continental, mas não normanda, do acontecimento! Em jeito de conciliação, Jim Bradbury 
aventou a possibilidade de o Carmen ser um poema escrito por volta de 1100, mas baseado num poema anterior de Guido de Amiens, de que constituiria uma espécie de "embelezamento".

Para além destas seis fontes principais, existem outras interessantes, mas que temos de considerar 'menores', seja por serem mais tardias, seja pela sua discutível fiabilidade. É, sobretudo, o caso do já referido Orderico Vital, filho de pai normando e de mãe inglesa, nascido em Atcham (Shrewsbury, na região de Chester), em 1075, e que escreveu uma Historia Ecclesiastica. O pai talvez integrasse a casa do nobre Roberto de Montgomery, e o jovem teve uma educação local, mas aos 10 anos foi enviado para Saint-Évroult (na floresta de Ouche, na Baixa Normandia) para ser monge. Aí acabou por morrer, em 1141 ou em 1142. Um dos primeiros trabalhos de Orderico consistiu no acrescento da crónica de Guilherme de Jumièges, mas depois lançou-se na composição de um autêntico opus magnum, que demorou trinta anos a concluir: a Historia Ecclesiastica é um trabalho longo e divagante, em que - à boa maneira da tradição historiográfica de Cluny - a história é escrita por círculos geográficos e cronológicos a partir do centro do mundo, que é o próprio mosteiro de Saint-Évroult. Trata-se de uma narrativa com um toque humano muito sensível e repleta de episódios divertidos, escrita numa bela caligrafia e não despida de algumas críticas às ações de Guilherme "o Conquistador", em especial depois de 1066. Orderico foi o único a localizar a batalha de Hastings na localidade de Senlac.

Guilherme de Malmesbury é outro autor que merece atenção. Foi um beneditino nascido cerca de 1090, filho de um casal anglo-normando, e que viajou imenso em busca de documentos para compor a sua De Gestis Regum Anglorum ("Sobre os feitos dos reis dos Ingleses"), datável de c. 1125. O facto de ler o inglês antigo, o francês e o latim ajudou a tornar este monge, que foi bibliotecário (e talvez chantre, isto é, diretor do coro) no mosteiro de Malmesbury (Worcester), um grande escritor, ainda que não nos dê informações especialmente relevantes sobre a batalha de Hastings. Malmesbury amplifica os relatos de Gildas e de Beda, e na sua obra percebemos já a presença de personagens famosas da chamada "matéria literária da Bretanha”, como o rei Artur, Galvão e o senescal Queia, entre outras. 
Outro grande escritor histórico foi Henrique de Huntingdon, arquidiácono de Huntingdon (na East Anglia), nascido cerca de 1080. Filho de padre e, ele próprio, pai de diversos filhos, viajou muito, tendo visitado Bec (uma abadia célebre, na Normandia) e Roma, entre muitos outros locais. Como notou Jim Bradbury, Henrique de Huntingdon tinha um verdadeiro faro de historiador e a sua Historia Anglorum ("História dos Ingleses"), que começou a ser escrita por volta de 1133 (até 1154), constitui uma ampla história da Inglaterra encarada de um ponto de vista favorável à região de East Anglia. Para compor esta obra, Henrique diz ter utilizado compilações de crónicas que pôde consultar em bibliotecas antigas. Também ele lia o inglês antigo com facilidade.

A mestre Wace (nascido nas Ilhas Channel, não antes de 1100, e falecido em 1184) devemos o célebre Roman de Rou, uma espécie de história em verso dos duques da Normandia, escrita provavelmente na segunda metade do séc. XII. Wace foi um "varlet" (um valete, ou pajem) com instrução militar, educado em Caen e que se tornou um escritor prolífico de romances em verso. Henrique II de Inglaterra foi seu patrono, o que the valeu receber como prebenda, durante dezanove anos, a catedral de Bayeux, onde decerto pôde conhecer ao pormenor a tapeçaria! O Roman de Rou, escrito em língua vulgar, é uma fonte muito útil e vívida, mas convém não esquecer que se trata de literatura, pelo que deve ser utilizada com muita cautela e apenas para passagens em que não haja dúvidas muito densas. Recorde-se que devemos a Wace, autor também de uma gesta dos Bretões (o Roman de Brut), composta c. 1155, a introdução na tradição literária arturiana da figura dos cavaleiros da Távola Redonda.

Por fim, uma palavra para a Crónica da Abadia de Battle, escrita depois de 1155, na própria abadia mandada construir por Guilherme no local da batalha. Não conhecemos o nome do autor, que era decerto um monge com fortes interesses jurídicos mas que forjou diversos documentos para valorizar a sua abadia... Em todo o caso, tem um grande conhecimento do terreno de batalha e da sua envolvente e, por isso, fornece pormenores únicos, como o nome da colina de "Telham Hill" ou o controverso "episódio Malfosse". 


\section{A Inglaterra na Alta Idade Média}

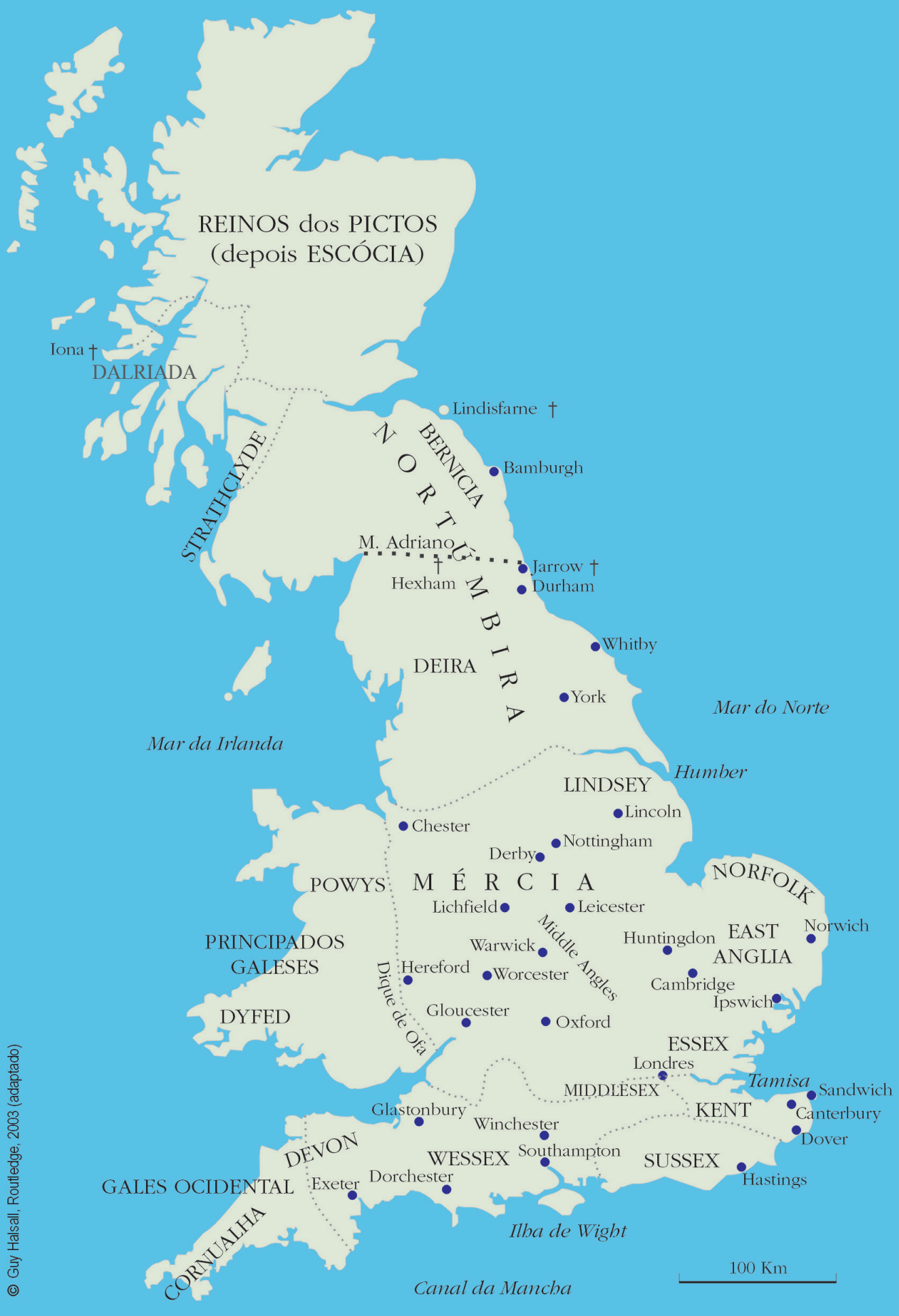




\section{A conquista anglo-saxónica da Bretanha romana}

Conquistada pelo imperador Cláudio em 43 d. C., a Bretanha foi, durante cerca de quatro séculos, uma província romana. Como tal, gozou da prosperidade e da ordem inerentes ao mais poderoso e duradouro império que o mundo ocidental conheceu. A partir de meados do séc. IV, porém, a situação começou a complicar-se. Às dificuldades sentidas um pouco por todo o mundo romano (reflexo da crise económica, da perda de autoridade política e da mutação das mentalidades), acrescentou-se um problema militar gravíssimo: a Bretanha começou a ser alvo das investidas de outros povos. A norte e a oeste, os Pictos e os Escotos, povos celtas, multiplicavam as suas investidas. A sul e a leste, eram os piratas germânicos (Anglos, Saxões e Jutos) que atacavam, colocando em sentido as autoridades militares romanas. A situação tornou-se ainda pior devido ao facto de, por vezes, no ambiente de degradação política a que se assistia, alguns generais romanos promoverem a sua própria candidatura ao trono imperial e, para o conseguirem, mobilizarem legiões inteiras de várias províncias, à frente das quais marchavam sobre Roma. Foi justamente o que aconteceu com Magno Máximo, a figura que inspirou Ridley Scott para o seu filme "O Gladiador" (2000): em 383, este general de origem hispânica 'desviou' as legiões da Gália e da Bretanha e avançou com elas para o coração do império; o projeto fracassou, mas as duas províncias ficaram extremamente enfraquecidas do ponto de vista militar.

Em 410, as autoridades romanas na Bretanha fizeram um último apelo ao imperador do Ocidente, Honório, para que as socorresse. Obtiveram uma resposta lapidar: mais valia contarem apenas com os seus próprios recursos, pois Roma já não estava em condições de as ajudar. Ou seja, Roma já não era Roma... A partir daqui, a situação precipitou-se, e tudo o que podia correr mal correu ainda pior. Os Escotos, um povo proveniente da Irlanda, fundaram primeiro o reino de Dalriada (na costa noroeste), mas até 850 dominaram os Pictos e fixaram-se na Escócia, a quem emprestaram o seu nome. Na aflição que resultou de tais ameaças, e a acreditar na narrativa de um monge bretão do séc. vi, Gildas, autor da obra De Excidio et conquestu Britanniae ("Sobre a destruição e a conquista da Bretanha"), um tirano bretão 
chamado Vortigern terá apelado a mercenários saxões instalados no norte da Alemanha e talvez na Frísia (atual Holanda) para que viessem auxiliá-lo na sua defesa contra os Pictos e os Escotos. Os Saxões cruzaram o Mar do Norte, cumpriram a sua missão e foram recompensados com algumas terras, o que os levou a estabelecerem-se no sul da Bretanha (em especial no Essex, no Sussex e no Wessex).

O célebre monge Beda "o Venerável", autor da Historia ecclesiastica gentis Anglorum ("História eclesiástica da nação dos Anglos") confirma esta versão e indica mesmo os nomes dos principais chefes saxões envolvidos neste processo: Hengest e Horsa, que a Historia Brittonum ("História dos Bretões”, c. 829-830) explicará mais tarde serem dois exilados que receberam de Vortigern uma terra em Thanet (no Kent), em recompensa pelo seu auxílio militar aos Bretões. Uma filha de Hengest terá até casado com o rei bretão, cimentando um período de boa convivência e colaboração que, contudo, não duraria muito tempo: no terceiro quartel do séc. V, já as rivalidades tinham minado a aliança entre Bretões e Saxões, com estes a revoltarem-se e a serem controlados a muito custo por Ambrósio Aureliano, um chefe celto-romano, que poderá ter inspirado a figura literária do rei Artur e que venceu os Saxões na batalha do Monte Badónico, c. ano 483. Apesar disso, nos anos seguintes e ao longo de várias décadas, a emigração saxónica para a Bretanha continuou em bom ritmo. A Crónica Anglo-Saxónica relaciona esse facto com a criação do reino de Sussex e cita até o caso de um líder saxão, Cedric, considerado como o antepassado dos reis do Wessex.

Para agravar a situação dos Bretões, a penetração dos mercenários saxónicos fez-se acompanhar pela dos Anglos. Estes devem ter vindo do sul da península da Jutlândia (atual Dinamarca) e instalaram-se no centro, no centro leste e no norte da Bretanha (ou seja, na Mércia, na Middle Anglia, na East Anglia e na futura Nortúmbria). Os Jutos, pelo seu lado, provavelmente originários também da Jutlândia mas em menor número, ter-se-ão estabelecido no Kent (no extremo sudeste), na Ilha de Wight e na costa do Wessex.

Deste modo, o destino dos Bretões ficou traçado: em 571, sofreram uma derrota importante às mãos dos Anglos, que em meados do séc. VII voltaram a derrotá-los, em Bradford-on-Avon (no Wessex). Ao mesmo tem- 
po, os Saxões iam estendendo o seu domínio ao Kent, à East Anglia e à Cornualha (no extremo sudoeste, onde os habitantes ainda resistiriam até inícios do séc. IX). Dois grandes líderes saxões, Ceolwulf e Cynegils, reis do Wessex na primeira metade do séc. VII, levaram a cabo a conquista da zona ocidental da Bretanha. À população nativa não restou pois outro caminho, a não ser fugir: fizeram-se ao mar e aportaram na Armórica, onde acabaram por se estabelecer para sempre, dando origem à Bretanha francesa. A antiga província romana da Bretanha tinha sido conquistada pela primeira vez na Idade Média e, graças à influência dos Anglos, chamava-se agora "Inglaterra" (repare-se no termo francês: "Angleterre").

Por volta do ano 600, verificamos a existência de pelo menos dez Estados independentes só no centro e sul da Inglaterra, resultado dos territórios que os líderes dos Anglos e dos Saxões foram esculpindo para si próprios, à medida que iam consolidando as suas conquistas; trata-se de uma dispersão de poder única na Europa do seu tempo. Já a norte, entre o citado reino da Escócia e o estuário do Humber (que praticamente divide a Inglaterra em duas metades: norte e sul), a conquista dos Anglos traduziu-se na formação de apenas dois reinos: o de Deira e o de Bernicia, com supremacia deste último.

Ao longo da primeira metade do séc. VII, graças à ação do grande rei dos Anglos, Penda (falecido em 655), iniciou-se um processo de afirmação política e militar do reino da Mércia, que conseguiu estender a sua autoridade a muitas regiões do sul (em especial do sudeste) e também à Middle Anglia (graças ao rei Peada, filho de Penda), à poderosa East Anglia e à região de Lindsey. Os sucessores de Penda e de Peada prosseguiram a obra e isso fez com que, até aos inícios do séc. Ix, pelo menos, o reino da Mércia desfrutasse de uma supremacia notória no centro e no sul da Inglaterra. O apogeu dos mercianos terá sido atingido durante o reinado de Ofa (756-796), um monarca que alcançou uma certa notoriedade internacional, tendo mantido relações diplomáticas com Carlos Magno. Enquanto isso, mais a norte, depois de vários avanços e recuos ocorridos ao longo do séc. VII, os reinos de Deira e de Bernicia acabaram por se fundir, dando origem à importantíssima região da Nortúmbria, com capital em York. 
A primeira metade do séc. IX trouxe a confirmação da tendência para a aglutinação das formações políticas, mas desta vez graças ao crescimento e afirmação do reino saxão do Wessex. O monarca Egberto chegou mesmo a derrotar os Mercianos (em 825) e os Nortumbrianos (em 830). Assim, quando chegamos aos meados do séc. IX, podemos dizer que só existem verdadeiramente três reinos no sul da Inglaterra (a Mércia, o Wessex e a East Anglia) e apenas um reino no norte (a Nortúmbria). Eis o quadro de referência em que assentará a história da Inglaterra nos próximos séculos.

\section{Paganismo e cristianismo}

Esta evolução político-militar foi acompanhada por importantes movimentações religiosas. Desde a primeira metade do séc. III que havia comunidades cristãs na Bretanha, e estas mostraram saber como resistir às invasões germânicas. Em 563, um monge irlandês, São Columbano, converteu os Pictos ao cristianismo e veio a fundar uma missão em Iona, o maior mosteiro escocês. Deste modo, o paganismo e o cristianismo coexistiram na Inglaterra dos Anglos e dos Saxões nestes primeiros séculos da Idade Média. No De temporum ratione ("Sobre o cálculo do tempo"), Beda explica que o calendário pagão inglês começava no dia 25 de dezembro, com a "noite das mães", seguindo-se o mês de "Giuli" (ou "Yule") e o "Salmonath" (o 2. ' mês, ou "mês dos bolos", a época em que se ofereciam bolos aos deuses); o 5..$^{\circ}$ mês chamava-se "Thrimilci", porque nesta altura do ano se ordenhavam as vacas três vezes por dia; já o $6 .^{\circ}$ e o $7 .^{\circ}$ meses eram dedicados à Lua ("Litha"), enquanto o 9. era o mês das oferendas (o mais sagrado de todos) e o $11 .^{\circ}$ o dos sacrifícios. Os Anglos e os Saxões adoravam os mesmos deuses dos outros Germanos: Twi (ou Tig), Thumor, Wotan (o deus dos trovões), Frig (a deusa da fertilidade, cujo nome está na origem de um dia da semana: "Friday"), entre outros.

Por volta do ano 600, o papa Gregório I, "o Magno", apostou fortemente na evangelização da Inglaterra, tendo para o efeito enviado para ali o monge Agostinho, que se estabeleceu no Kent (na ilha de Thanet). Agostinho levava instruções para não ser violento com os pagãos e para 
tentar conduzir os Anglo-Saxões de uma forma gradual e harmoniosa para a religião cristã: "não é preciso destruir os templos, mas apenas os ídolos que neles se encontram", explicava sagazmente o papa. Agostinho tornou-se bispo de Canterbury em 601 e converteu o Kent, sendo a sua obra prosseguida por Melito, a partir de 619 - o cristianismo fazia progressos evidentes no sul da Inglaterra.

Enquanto isso, dava-se também a evangelização da Nortúmbria, facilitada pelo casamento do rei Edwin com uma filha do rei do Kent; o bispo de York, Paulino, batizou Edwin em 627 e alcançou grande sucesso nesta região a norte do Humber; em 634, o rei Osvaldo da Nortúmbria reconheceu o cristianismo na região. Fazia-se aqui sentir fortemente a ação dos monges vindos de Iona e da Irlanda, que promoveram uma cristandade celta com muitas diferenças em relação à de Roma (p. ex., no cálculo da data da Páscoa, na forma de ministrar o batismo, na tonsura clerical ou na própria figura dos 'bispos-monges'). Por isso, pode dizer-se que a evangelização do norte da Inglaterra foi obra de missionários irlandeses com escassos contactos com Roma, mas, em 664, um sínodo reunido em Whitby tratou de dirimir os problemas suscitados pelas divergências daí resultantes, acabando por consagrar o triunfo das práticas romanas. Ao longo da segunda metade do séc. VII, monges como Teodoro de Tarso, Adriano (um africano) e Bento Biscop (oriundo de uma família nobre da Nortúmbria) reorganizariam a igreja cristã em Inglaterra, desde Lindisfarne (um mosteiro estabelecido numa ilha de maré da costa nordeste) até Canterbury. Coube a Bento Biscop fundar os grandes mosteiros de Monkwearmouth (em 674) e de Jarrow (em 681, onde viveria Beda), cenóbios que enriqueceu com livros e com objetos de arte trazidos de Roma e que se tornaram os dois grandes centros culturais do Norte da Inglaterra. Quanto à tradição celta, acabou por sobreviver apenas no País de Gales, até pouco depois de meados do séc. VIII.

\section{Os Vikings reinam em Inglaterra}

Ainda a síntese resultante da conquista anglo-saxónica e da expansão do cristianismo em ambiente pagão não estava consolidada e já a Inglaterra se confrontava com uma nova ameaça: a protagonizada pelos Vikings (dina- 
marqueses e noruegueses). O alarme soou em junho de 793, com o saque do mosteiro de Lindisfarne, a que se seguiu, em 794, o incêndio de Jarrow e, em 795, o incêndio de Iona. Em três anos, desapareciam os três grandes centros da cristandade inglesa às mãos dos novos invasores!

Os ataques dos Vikings - que privilegiavam as abadias, devido ao metal precioso e outras riquezas que estas abrigavam - percorriam as grandes estradas marítimas. Os Noruegueses vinham pelos fiordes do norte e faziam caminho pelas Ilhas Shetland, Ilha de Man e Irlanda. Já os Dinamarqueses apareciam vindos de sul, da Jutlândia, e, depois de atravessarem o Mar do Norte e o Canal da Mancha, assolavam as regiões meridionais da Inglaterra.

Entre 800 e 850, os raides vikings tornaram-se regulares. Aconteciam na primavera e no verão, quando havia bom mar, e traduziam-se em assaltos fulgurantes, do estilo 'pilhar e partir'. Porém, de 850 em diante, os Vikings começaram a mostrar tendência para invernar em Inglaterra. Ou seja, passaram de uma estratégia de invasão para outra de conquista e ocupação de um espaço. Esta evolução criou grandes dificuldades aos Anglo-Saxões, que não dispunham de frotas capazes de resistir aos seus adversários. Para agravar a situação, a partir de 826, as Ilhas Faroé, as Shetland e as Orkney (ou Orcades, $16 \mathrm{~km}$ a norte da Escócia) ficaram submetidas aos Noruegueses, que começaram a usá-las como bases permanentes para atacar a Escócia e a Irlanda. A Ilha de Man (no Mar da Irlanda, curiosamente equidistante da Escócia, da Inglaterra e da Irlanda) seria conquistada em 850. Em 853, um chefe norueguês, Olavo, tornou-se rei da Irlanda e fixou a sua capital em Dublin.

Entretanto, a sul, desde 835 que os raides dinamarqueses se haviam tornado praticamente anuais e assim continuaram durante cerca de trinta anos, visando sobretudo a região de Kent, que se encontrava submetida ao reino de Wessex. No outono de 865, dar-se-ia uma importante viragem: um grande exército dinamarquês, chefiado por Ivar e por Halfdan, desembarcou e instalou-se durante um ano inteiro na East Anglia; munidos de armas e de cavalos obtidos nas regiões saqueadas, estes 'Vikings do sul' entraram em York em 1 de novembro de 866, tendo atacado depois a Mércia (com penetração até Nottingham) e regressado a York para passar o inverno de 868-869. O rei da East Anglia, Edmundo, bem tentou travar esta calamidade, mas foi vencido e morto: a East Anglia foi devastada e o reino do mártir Edmundo foi extinto... 
Foi então que se iniciou uma das sagas mais entusiasmantes da história medieval inglesa. Referimo-nos à resistência dos reis do Wessex - Ethelred I (866-871) e, sobretudo, o seu irmão Alfredo (871-899) - aos invasores dinamarqueses. Estes dois monarcas protagonizaram uma oposição tenaz e organizada aos Vikings, que atacaram sucessivamente Londres, a Mércia, o Yorkshire, o Cambridgeshire e o próprio Wessex em raides destruidores e que se desenvolveram ao longo de toda a década de 870. Em alguns casos, os monarcas ingleses compraram a partida dos Dinamarqueses pagando-lhes um tributo; noutros, defrontaram-nos em batalha campal, tendo por vezes obtido vitórias importantes, como a de Ethelred I em Ashdown, em 871 (contra Halfdan e Bagsecg), ou a de Alfredo em Edington, em 878 (sobre Guthrum, que acabaria por se converter ao cristianismo e por se fixar na East Anglia).

Os ataques dos Noruegueses e dos Dinamarqueses fizeram com que, nos finais do séc. IX, o Wessex fosse o único reino inglês independente: tudo o mais havia sido ocupado pelos Vikings, prenunciando uma segunda conquista medieval da Inglaterra! Este facto reforça a importância da ação política do rei Alfredo, justamente cognominado "o Grande"; em 886, ele conseguiu recuperar Londres, unificou a resistência anglo-saxónica contra os nórdicos e construiu uma rede de fortificações defensivas em cidades estratégicas (os famosos buhrs) para consolidar as suas posições face aos raides escandinavos. Mas estes não acalmavam e, em 892, uma nova frota viking surgia no Kent e atacava Chester, sendo o País de Gales devastado no inverno de 893-894. A tenacidade de Alfredo e a sua capacidade para federar as bolsas da resistência anglo-saxónica impediram males maiores e asseguraram a sobrevivência do Wessex. A partir de 899, com a morte de Alfredo (que, além do mais, foi impulsionador e coautor de uma obra cultural notável), os seus filhos e netos prosseguiram a sua missão: Eduardo "o Antigo" (899-924) e Ethelstam (925-939) recuperaram muitos dos territórios perdidos para os Dinamarqueses. Com Eduardo, a Mércia foi incorporada no Wessex (em 918); Ethelstam, pelo seu lado, chegou mesmo a tomar York e a derrotar o rei Constantino da Escócia e os seus aliados, os líderes vikings de Dublin e da Nortúmbria, na batalha de Brunanburh, em 937. Pode, por isso, dizer-se que Ethelstam reinou já sobre toda a Inglaterra. 
Os seus sucessores, Edmundo (939-946) e Eadred (946-955), ambos irmãos de Ethelstam, expulsariam o último rei escandinavo de York, Eric Bloodaxe ("machado sangrento"), em 954, pondo termo às tentativas vikings para o estabelecimento de um reino independente em York, a maior cidade de Inglaterra a seguir a Londres. Com isto, a Nortúmbria passou a ser dirigida por earls (condes) ao serviço do rei anglo-saxónico.

Terminada a saga que Alfredo havia iniciado e que permitiu a sobrevivência política dos Anglo-Saxões em Inglaterra, entrou-se num período de relativa paz e prosperidade, assinalando o fim da primeira vaga de invasões vikings. O maior expoente desta fase, que se prolongou até perto de 991 , foi o rei Edgar (959-975), a quem se ficou a dever a reorganização e desenvolvimento do reino anglo-saxónico, uma renovação monástica brilhante (com o apoio de três clérigos de primeira água: Dunstan, bispo de Londres e de Worcester, Ethelwood, bispo de Winchester, e Osvaldo, um reformador vindo do mosteiro francês de Fleury-sur-Loire) e ainda um acordo com o rei Kenneth da Escócia. Deste trato resultaria, aliás, a fixação no rio Tweed, por muitos séculos, da fronteira entre a Escócia e a Inglaterra. Curiosamente, Edgar é o primeiro monarca inglês que sabemos ter sido coroado e ungido, numa cerimónia realizada em Bath - a velha e esplêndida cidade romana do Wessex - no ano de 973.

Em 980, recomeçaram os raides vikings, mas de início apenas com algum impacto local. Em 991, todavia, surgiu uma grande frota dinamarquesa, e o rei Ethelred II (978-1016), filho de Edgar, optou por pagar um tributo (o "danegeld", isto é, o "dinheiro dinamarquês") para que ela se retirasse. Não obstante, a ameaça reapareceu constantemente nos anos seguintes (992, 993, 994), e o danegeld (no fundo, uma taxa que os homens livres tinham de pagar ao rei de Inglaterra para que este pudesse comprar a retirada dos nórdicos) tornou-se cada vez mais frequente. Um filho do rei da Dinamarca, chamado Sven (ou Svend) Forkbeard (a alcunha significa algo como "barba bifurcada"), chegou a armar uma frota em parceria com um viking famoso, Olavo Tryggvason, mas acabaram por se desentender entre si e por regressar à base, tendo Olavo conseguido tornar-se rei da Noruega; em 997, um outro exército viking devastou o sudoeste de Inglaterra, atacando a região do Sussex no ano seguinte e o Hampshire em 999. Ethelred II parece ter 
então pago um tributo de 24000 libras, o que muito deve tê-lo indignado: saturado da pressão viking, este rei tomaria em 1003 a trágica decisão de ordenar o massacre de todos os Dinamarqueses em Inglaterra (incluindo a irmã de Sven Forkbeard, Gunnhild, que guardava como refém)... A reação nórdica a este ato brutal não se fez esperar: Sven atacou a cidade sulista de Exeter com um grande exército e devastou a East Anglia em 1004. Regressou no ano seguinte e exigiu de Ethelred II o pagamento do monumental tributo de 36000 libras. Não contentes, em 1010, os Vikings devastaram Oxford, seguindo-se Ipswich, em 1011, e Canterbury, em 1012; aqui, assassinaram o arcebispo Elfheah, que se recusara a pagar um resgate. Este facto provocou algumas divisões no seio dos Vikings, tendo um dos líderes dinamarqueses, Thorkel, decidido colocar-se ao serviço do rei inglês, com os seus 45 barcos; Ethelred II nomeou-o então rei dos Five Boroughs (Lincoln, Nottingham, Derby, Stamford e Leicester) e usou-o para defender Londres contra os ataques de Sven.

A estratégia, porém, não resultou: em 1013, Sven acabou por tomar Londres e por submeter toda a Inglaterra. Ethelred II, que casara com Ema, uma filha do duque Ricardo I da Normandia (e de uma sua amante e, depois, esposa: Gunnor, uma mulher de origem dinamarquesa-normanda), não teve outro remédio senão fugir para a Normandia, acompanhado pela esposa e por dois filhos do casal - Eduardo e Alfredo. Com isto, pela primeira vez um rei escandinavo, de seu nome Sven Forkbeard, governava a Inglaterra anglo-saxónica!

Sven não teve, porém, muito tempo para saborear o seu triunfo, pois faleceu logo em fevereiro de 1014. Nessa altura, os Vikings escolheram Cnut (ou Knud, o filho mais jovem de Sven) para lhe suceder, mas os nobres ingleses optaram por apelar a Ethelred II para que regressasse a Inglaterra (embora, segundo reza a Crónica Anglo-Saxónica, exigindo-lhe que os governasse melhor do que fizera no passado). Ethelred II concordou e impôs aos Dinamarqueses o seu regresso, tendo Cnut, por falta de apoios internos, sido forçado a abalar para a Dinamarca, onde o seu irmão Haroldo se tornara rei.

Ethelred II veio com Ema da Normandia, mas os dois filhos do casal, Eduardo e Alfredo, permaneceram junto do duque Ricardo II em terras normandas. Ao que sabemos, Ethelred II (cognominado "Unraed", isto é, 
"o Indeciso") delegou quase de imediato as suas competências de governo da Inglaterra no filho Edmundo, conhecido como Ironside ("o Enérgico"), nascido de um casamento anterior de Ethelred II com Aelfgifu da Nortúmbria. Como seria de esperar, Edmundo não teve vida fácil: lá na Dinamarca, Cnut preparava com o irmão Haroldo e com Thorkel uma nova invasão da Inglaterra, de modo a reclamar com sucesso o trono que o seu pai quisera deixar-lhe.

Em 1015, se não mesmo antes, Cnut reapareceu em Inglaterra acompanhado de um forte exército escandinavo. Recolheu o apoio de alguns thegns (nobres) anglo-saxónicos (como Eadric Streona), tomou conta do chamado Danelaw (o território que permanecia submetido aos Dinamarqueses, no centro e norte de Inglaterra) e controlou a região da Mércia. Ainda assim, Edmundo decidiu-se a fazer-lhe frente, mas foi obrigado a fugir de Londres, apesar da vitória que alcançou em Brentford; marchou para o norte e aliou-se ao conde da Nortúmbria, Uhtred, mas Cnut perseguiu-o e atacou York, forçando Uhtred a submeter-se-lhe (o que não lhe valeu de muito, pois Cnut matou-o na mesma). Então, Cnut nomeou um dos seus homens, Eric (que servira com Sven Forkbeard), como novo conde da Nortúmbria.

Em abril de 1016, faleceu o incompetente Ethelred II, o que deve ter reforçado um pouco a posição política de Edmundo, que ainda possuía partidários na velha base de apoio dos reis do Wessex e noutras regiões do sul e que foi aceite como rei tanto em Londres como no Wessex. Porém, havia ainda que travar uma batalha decisiva contra Cnut, que teria lugar em Assandun (talvez Ashingdon, no Essex) e de que este saiu vencedor, embora sofrendo muitas baixas. No entanto, ciente de que a sua posição política era ainda frágil, Cnut optou por fazer um acordo com o seu rival: Edmundo ficaria com o Wessex, a região mais importante do sul da Inglaterra, embora Londres e a Mércia ficassem do seu lado. Edmundo Ironside aceitou, mas o acordo teve vida curta devido à sua morte, logo em novembro de 1016. Por segurança, os seus filhos foram enviados para a Suécia e, depois, para a Hungria. Um desses filhos, também chamado Edmundo, morreria neste reino, mas um outro, conhecido por Eduardo "o Exilado", permaneceu longamente na corte húngara e veio até a casar com uma mulher nobre chamada Ágata, que era sobrinha do imperador germânico Henrique II. De Eduardo "o Exilado", um nome a reter, voltaremos a falar um pouco mais à frente. 
Cnut viu então submeterem-se-lhe todos os grandes da Inglaterra, incluindo os do Wessex, o berço da monarquia anglo-saxónica. Assim, em finais de 1016, um novo chefe escandinavo chegava ao trono inglês, e desta feita de forma um pouco mais duradoura: ao contrário do pai, Sven Forkbeard, Cnut reinaria durante quase 20 anos (1016-1035) e dois dos seus filhos suceder-lhe-iam. Ao que tudo indica, apesar de dinamarquês, foi bem aceite em Inglaterra e também pelos principais reis cristãos do Ocidente. Convertido ao cristianismo, Cnut tornou-se um protetor da Igreja e estabeleceu relações cordiais com diversos príncipes do continente e com o próprio papa. Em 1027, parece que realizou uma peregrinação a Roma, para assistir à coroação do imperador Conrado II.

No reinado de Cnut, a Inglaterra foi dividida em quatro regiões principais, que foram entregues aos grandes do reino: a Mércia, a Eadric Streona; a East Anglia, a Thorkel; e a Nortúmbria, a Eric da Noruega; quanto ao Wessex, ficou sob a tutela do próprio Cnut. Pouco depois, teve lugar a traição de Eadric Streona e, após a execução deste, a Mércia foi temporariamente dividida em condados.

Logo em 1017, Cnut tomou uma decisão um pouco paradoxal, mas de grande inteligência política: casou em segundas núpcias com a viúva de Ethelred II, Ema da Normandia! Isso reforçou os seus direitos em Inglaterra e, ao mesmo tempo, dissipou as expetativas de um eventual apoio normando aos jovens exilados, Alfredo e Eduardo. O duque da Normandia, Ricardo II (filho de Ricardo I e de Gunnor e, portanto, já cunhado de Cnut por via da sua irmã Ema), reconheceu Cnut como rei da Inglaterra. Em 1017, uma irmã deste (chamada Estride) viria até a casar com Ricardo II (tornando-os duplamente cunhados), comprometendo assim, ao menos por algum tempo, a posição dos dois filhos de Ethelred II e de Ema. Famosa pela sua fealdade (que um exame recente do seu esqueleto confirmou), Estride depressa foi repudiada pelo marido, tendo acabado por casar mais tarde com o conde Ulf e por se tornar mãe de Sven II Estridsen, o futuro rei da Dinamarca.

Em 1018, à morte do seu irmão Haroldo, Cnut apoderou-se do trono da Dinamarca, onde deixou Thorkel a governar em seu nome, e dez anos mais tarde tornar-se-ia também rei da Noruega. Estava criado o império de Cnut "o Grande", que, para além da Inglaterra, da Dinamarca e da Noruega, incluía 
também algumas partes do sul da Suécia e o senhorio do reino da Escócia, das ilhas escocesas e da Irlanda escandinava! Monarca duro e implacável, é geralmente reconhecido que ele trouxe ordem, estabilidade e prosperidade à Inglaterra, tendo impulsionado a elaboração de um importante código legal (no que contou com a colaboração de Wulfstan, bispo de York) e estimulado o comércio. Sob o seu governo, Londres desenvolveu-se de forma significativa, tirando partido de relações comerciais e comunicações mais fáceis com o Norte da Europa. Teve também lugar uma reforma monetária, ao mesmo tempo que se desenvolveu a indústria, em especial nos domínios do sal, do chumbo e do estanho.

Como seria de esperar, Cnut tratou de recompensar aqueles que o tinham ajudado a conquistar o trono que fora de Ethelred II e foi pródigo na distribuição de terras a compatriotas dinamarqueses, o que cimentou a presença escandinava em Inglaterra. No entanto, entre os seus principais conselheiros e validos, contavam-se também alguns Anglo-Saxões, entre eles Godwin Wulfnotson, provavelmente filho de um pequeno nobre do Sussex (chamado talvez Wulfnot Cild) e pai de um dos heróis da nossa história (o rei Haroldo II, que chefiará a hoste inglesa na batalha de Hastings). Godwin deve ter nascido por volta de 980 e, nos inícios do séc. XI, era já um dos homens mais influentes de Inglaterra. Graças ao seu casamento com Gyda Torgilsdatter Spragalaeg, irmã de um cunhado de Cnut (o citado conde Ulf, que chegou a representar Cnut na Dinamarca), construiu uma relação de proximidade com o grande rei viking da Inglaterra, de quem deve ter sido um dos principais apoiantes. Em retribuição da sua fidelidade, Cnut nomeou Godwin como conde do Wessex, um dos títulos mais importantes de Inglaterra (ou mesmo o mais importante, a seguir à realeza). Pela mesma altura, Cnut deve ter entregado a Mércia nas mãos de Leofric (o filho de um conde de Ethelred II), enquanto a Nortúmbria passou para as de Siward, um dinamarquês que era casado com uma neta do antigo conde Uhtred. Autoritário e centralizador, Cnut teve de se aplicar para manter os vários condes sob controlo apertado, algo a que eles não estavam lá muito habituados... Um dos seus mais antigos apoiantes, Thorkel, chegou mesmo a ser exilado e proscrito, em 1021, embora se tenha mais tarde reconciliado com o monarca. 
Em 1035, ocorreu a morte de Cnut “o Grande”. Nessa altura, já o seu império estava em desagregação e a sucessão não deixava de ser um pouco incerta, dado que ele contraíra dois matrimónios em períodos muito próximos. A sua primeira mulher, Aelfgifu de Northampton, que colaborara no governo dinamarquês da Noruega, interessou-se pela sucessão do ex-marido, uma vez que dele tinha dois filhos: Sven, que foi rei da Noruega, e Haroldo Harefoot (literalmente: "pé de lebre"). Mas o preferido de Cnut parece ter sido Hartacnut, um dos dois filhos resultantes do matrimónio com Ema da Normandia (o outro descendente foi uma menina chamada Gunnhild, que casou com o imperador germânico Henrique III); antes de falecer, o grande rei viking da Inglaterra teria exprimido o desejo de que fosse este filho a suceder-lhe nos tronos de Inglaterra e da Dinamarca.

Acontece, porém, que, na altura da morte do pai, Hartacnut se encontrava na Dinamarca, onde uma série de questões relacionadas com a pressão de Magno "o Bom" o retinha. Magno tinha sido forçado a deixar a Noruega entre 1028 e 1035, mas, depois da morte de Cnut, os nobres noruegueses, cansados de viver sob a lei dinamarquesa, apelaram ao seu regresso e ofereceram-lhe o trono. Magno tornou-se então rei da Noruega, desfazendo assim um dos elos mais importantes do império de Cnut; todavia, não contente com o facto, depressa começou a revelar as suas ambições ao trono da Dinamarca. Ora, isso absorvia as atenções de Hartacnut e também de Sven, pelo que foi Haroldo Harefoot quem tirou agilmente partido da situação e aproveitou para se tornar rei de Inglaterra, sob o nome de Haroldo I (1037-1040). Para tanto, contou sobretudo com o apoio dos condes de Mércia e da Nortúmbria (ou seja, com os dois grandes barões do centro e norte), enquanto os colaboradores mais próximos de Cnut (como o conde Godwin de Wessex ou o arcebispo de Cantuária: os maiores poderes do sul) se terão mostrado, numa fase inicial, adeptos da candidatura de Hartacnut, tendo-se depois rendido à evidência perante a impossibilidade de este vir defender a sua causa em Londres.

Neste processo, não ficou muito clara a posição de Ema da Normandia, a rainha duplamente viúva. Ao que parece, ela terá incitado os seus filhos Eduardo e Alfredo, exilados desde crianças na Normandia, a candidatar-se ao trono inglês. Eduardo optou por permanecer no exílio, mas, em 1036, 
Alfredo acorreu a Inglaterra, cheio de ilusões e acompanhado por uns 600 guerreiros normandos. Chegou, porém, numa altura em que tudo já estava decidido a favor de Haroldo I: atraído a Guildford pelo conde Godwin (que então estaria já comprometido com Haroldo Harefoot), foi atacado e capturado durante uma noite de banquete, tendo nove dos dez homens do seu séquito pessoal sido decapitados na sua presença; Alfredo foi depois levado para Ely, onde um tribunal dinamarquês o condenou a ser cegado por ter violado a paz do reino. O filho de Ethelred II e de Ema não sobreviveu ao castigo, mas a sua morte deixou um lastro de suspeita sobre os comportamentos indignos e brutais de Haroldo e do conde Godwin.

Haroldo I não duraria muito tempo mais. Na primavera de 1040, depois de um breve e sombrio reinado de três anos, faleceu em Oxford, aos 25 anos de idade. Nessa altura, já Ema da Normandia, talvez expulsa de Inglaterra pelo rei e refugiada na Flandres, na corte do conde Balduíno V, promovia reuniões e acordos entre dois dos seus filhos: os meios-irmãos Eduardo (filho de Ethelred II) e Hartacnut (filho de Cnut "o Grande"). Tanto quanto parece, Ema conseguiu uma aliança entre ambos, que se revelaria bastante sólida. Além disso, em 1038, Hartacnut fizera também um acordo com Magno "o Bom” da Noruega (que seria rei da Dinamarca, à sua morte), o que lhe permitiu preparar com tempo a reivindicação do trono de Inglaterra. Assim, quando Haroldo I faleceu, em março de 1040, já Hartacnut tinha 10 navios mobilizados na Flandres e se aprestava para vir reclamar a herança política que o seu pai quisera legar-lhe.

Hartacnut chegou a Inglaterra acompanhado da mãe, Ema, o que lhe permitia controlar qualquer ameaça normanda e reforçar o seu acordo com o meio-irmão Eduardo; mãe e filho aportaram em Sandwich, no Kent, vindos de Bruges, com 62 "navios longos"; o corpo de Haroldo I foi exumado, decapitado e lançado ao rio Tamisa. Pouco depois, Hartacnut conquistava o trono de Inglaterra, tendo de imediato salvaguardado uma posição honrosa para Eduardo, que foi convidado a regressar a Inglaterra, talvez como comonarca e herdeiro - apesar das dificuldades, a dinastia viking continuava a dar as cartas em Inglaterra. O conde Godwin foi julgado pelo seu envolvimento na morte de Alfredo, mas escapou graças a uma oferta monumental ao seu novo senhor: um drakkar (barco viking ostentando um dragão na proa) 
com ferragens de ouro e com 80 guerreiros, cobertos por um capacete de ouro e munidos de um machado de guerra de ouro no ombro esquerdo e de uma lança na mão direita, com os braços repletos de anéis dourados...

A Fortuna, porém, não favoreceu os filhos de Cnut "o Grande": sete anos depois da morte deste (em 1035), já todos eles tinham falecido, incluindo Hartacnut, que morreu de apoplexia em 1042, durante uma boda dinamarquesa realizada perto de Londres. Contava apenas 24 anos de idade e reinara durante somente dois anos (1040-1042). A sua sucessão, contudo, tinha sido antecipadamente preparada, e Eduardo não parece ter tido grandes dificuldades em ocupar o lugar do meio-irmão, com isso pondo termo a quase três décadas de domínio dinamarquês em Inglaterra (1013-1042).

\section{Eduardo "o Confessor" (1042-1066)}

Existem alguns sinais de que Ema da Normandia poderá ter-se batido para que a sucessão de Hartacnut fosse assegurada, não por Eduardo, mas sim por Magno da Noruega (que então se tornou rei da Dinamarca). Se assim sucedeu, não deixa de ser curioso, pois Eduardo era filho da própria Ema, que pelos vistos não morreria de amores pelos descendentes que Ethelred II lhe dera enquanto jovem...

Seja como for, na Páscoa de 1043, Eduardo foi solenemente coroado em Winchester. A monarquia anglo-saxónica estava de volta, mas até nem parecia evidente: é que o novo rei, então já com quase 40 anos de idade (nascera em 1004), vivera os últimos 30 anos na Normandia, onde se exilara com os pais e o irmão Alfredo, quando o primeiro viking, Sven Forkbeard, conquistara o poder em Inglaterra. Eduardo era muito mais normando do que inglês e parece que até preferia falar o francês, pois estava impregnado da cultura e da tradição francas, que lhe haviam moldado o estilo e o caráter. A sua educação tinha sido assegurada na corte do tio materno, o duque Ricardo II (996-1026), a quem o tinham ligado laços de grande afetividade e respeito; uma fonte declara mesmo que Ricardo o amava e tratava como se fosse seu filho. Eduardo era agora um rei incontestado, mas nem por isso deixava de governar um país que lhe era estranho e onde decerto se sentiria, de início, um pouco perdido, numa corte repleta de Dinamarqueses! 
Não é, pois, de estranhar que Eduardo se tenha protegido, fazendo-se rodear de conselheiros e de prelados normandos da sua confiança pessoal, que chamou para junto de si logo que foi coroado. Entre estes validos, destacavam-se Roberto de Jumièges, que o novo monarca haveria de ajudar a ser bispo de Londres e arcebispo de Canterbury (em 1051), e Rodolfo de Mantes, que seria feito conde de Hereford. Ao mesmo tempo, a guarnição de Dover, no Kent, uma praça que era considerada a chave do acesso sul à Inglaterra, passou a ser composta por tropas normandas. Quanto à mãe, Ema, Eduardo parece ter-lhe retribuído a sua falta de afeição com o confisco, em 1043, de todas as suas terras e de um número incalculável de objetos de ouro e de prata; o bispo de East Anglia, Stigand, considerado o conselheiro mais influente de Ema, foi despromovido, e os seus bens foram igualmente confiscados. Mais tarde chegaria, contudo, o momento da reconciliação.

Começava assim um frutuoso reinado, que haveria de se prolongar até aos primeiros dias do dramático ano de 1066. Eduardo encontrou uma Inglaterra muito dividida entre populações anglo-saxónicas e escandinavas e com condes muito poderosos, entre os quais Godwin de Wessex, o mais que provável mentor do brutal assassinato do seu irmão Alfredo... Para além disso, o rei não podia descurar as ameaças externas. É certo que já não havia qualquer filho vivo de Ethelred II ou de Cnut "o Grande", mas existiam outros perigos: Magno "o Bom" da Noruega e da Dinamarca (que faleceria em 1047, mas que ainda deu conta a Eduardo das suas pretensões anglófonas); Sven Estridsen, o neto de Sven Forkbeard e sobrinho de Cnut (uma vez que era filho da desgraciosa Estride), que seria rei da Dinamarca entre 1047 e 1074; o aventureiro Harald Hardrada, sucessor de Magno na Noruega e um dos protagonistas dos acontecimentos de 1066; e até os condes da Mércia (Leofric) e da Nortúmbria (Siward), tradicionalmente avessos ao domínio sulista e que constituíam uma ameaça permanente à paz do reino. Não era ainda de excluir a ocorrência de novos raides vikings contra a Inglaterra, à maneira do que sucedera em épocas bem recentes.

Se os grandes desafios é que fazem os grandes homens, pode dizer-se que Eduardo se mostrou um monarca talentoso e determinado, em especial na primeira fase do seu reinado (até 1052). Em primeiro lugar, soube tirar bom partido dos trunfos que tinha: o prestígio que advinha de ser oriundo 
da casa de Wessex; o facto de ser o homem mais rico do reino; as suas boas relações com a Normandia (de que era então duque Guilherme II, que viria a ser o líder normando na batalha de Hastings, mas que na altura se encontrava ainda a braços com muitos problemas internos); a circunstância de a sua irmã, Godgifu, ter casado no seio da nobreza de França; o apoio expresso da Igreja, bem documentado pela presença, na sua coroação, dos arcebispos de York e de Canterbury, as duas principais dignidades eclesiásticas inglesas; e o reconhecimento da generalidade dos líderes europeus, desde o imperador germânico aos reis da França e da Dinamarca. Para consolidar a sua posição política, Eduardo decidiu ainda, em 1045, casar com uma filha do conde Godwin, chamada Edite. Aliavam-se assim, pela via matrimonial, os dois principais poderes políticos, económicos e sociais da Inglaterra!

O casamento de Edite com Eduardo não apaziguou, todavia, as tensões já existentes entre o monarca e o segundo homem mais poderoso de Inglaterra: o conde Godwin opunha-se frontalmente à orientação pró-normanda do governo do seu genro, assim como aos critérios régios de nomeação para os principais cargos eclesiásticos. Em determinada altura, essas divergências quase colocaram os respetivos exércitos frente a frente no campo de batalha e sentia-se que, a qualquer momento, o verniz acabaria por estalar. E, de facto, em 1051, rebentou um conflito violento, que atirou a família Godwin para o exílio. O pretexto foi uma visita de Eustácio de Boulogne (um adversário de Balduíno V da Flandres) a Inglaterra, para visitar o seu cunhado - a primeira esposa de Eustácio era justamente Godgifu, a irmã do monarca inglês. No regresso a Dover, de onde haveria de se fazer de novo ao mar, o séquito de Eustácio envolveu-se em desacatos com a população local, de que resultaram diversos feridos e mortos. Uma vez que Dover ficava no condado de Godwin, o rei exigiu que este punisse a cidade pelos maus-tratos infligidos à comitiva de Eustácio, mas o velho conde recusou-se a fazê-lo. Então, Eduardo convocou um concílio para Gloucester, onde Roberto de Jumièges acusou o chefe da família Godwin de conspirar contra o monarca. Velhos ressentimentos (em especial o assassinato de Alfredo) devem ter vindo então à tona. Com o apoio de muitos nobres (entre os quais Rodolfo de Mantes) e com a sua autoridade bem estabelecida no reino, o monarca levou a melhor e forçou Godwin a recuar: em setembro de 1051, o conde 
fugiu para o seu manor de Bosham e daí para o exílio na Flandres, junto de Balduíno V. Com ele, seguiram também a esposa, Gyda, e pelo menos dois filhos do casal: Tostig e Gyrd, devendo notar-se que, por esta altura, Tostig casou com uma meia-irmã do conde da Flandres, chamada Judite; outros dois filhos, Haroldo e Leofwine, exilaram-se na Irlanda; quanto à rainha Edite, foi encerrada num convento em Inglaterra.

Vencido o braço-de-ferro, Eduardo pôde então governar sem oposição e, decerto, aproveitou para reforçar a sua política pró-normanda. Terá sido nesta altura, em finais de 1051 ou no primeiro semestre de 1052, que recebeu em Londres a visita do duque Guilherme II da Normandia, por quem parece que tinha grande apreço e a quem o ligava, aliás, um parentesco remoto: Ema da Normandia, mãe de Eduardo, era tia-avó de Guilherme. Possivelmente, se esta visita teve realmente lugar (a Crónica Anglo-Saxónica dá conta dela, embora só lhe dedique algumas linhas), terá sido então que Eduardo prometeu a Guilherme que, à sua morte, o trono de Inglaterra passaria para as suas mãos; ou então, dado que a monarquia inglesa era eletiva, que faria os possíveis e usaria de toda a sua influência e poder para que isso viesse a acontecer. Em sinal deste compromisso, o rei inglês poderá ter nessa altura entregado ao duque dois familiares próximos do seu mais notável súbdito, isto é, do conde Godwin: o filho mais novo, Wulfnot Godwinson, e um dos netos, Hakon, que em breve encontraremos na corte ducal da Normandia, como reféns. As fontes normandas, curiosamente, não dizem bem isto: Guilherme de Poitiers e Guilherme de Jumièges ignoram a putativa deslocação do duque a Inglaterra e declaram que a promessa foi feita, sim, mas através do envio do arcebispo Roberto de Cantuária à Normandia, juntamente com os dois reféns.

Seja como for, o resultado do conflito entre o rei e o seu mais poderoso valido, o conde Godwin, abona claramente a favor da autoridade de Eduardo e sugere o seu amplo controlo da situação política em Inglaterra. Contudo, as aparências iludem. É que, em setembro de 1052, exatamente um ano volvido sobre a fuga para o exílio, os Godwin forçaram o seu regresso a Inglaterra! Contaram, para o efeito, com fortes apoios internos e, claro, com a solidariedade do conde de Flandres. Godwin juntou a sua frota à do filho Haroldo, recolheu numerosos apoios (entre os quais o de marinheiros 
dinamarqueses dos portos do Kent e do Sussex), subiu o Tamisa rumo a Londres e ancorou em Southwark, na margem esquerda do rio, pronto para dar batalha ao rei. A frota real, muito inferior em número, ficou bloqueada, e Eduardo foi obrigado a negociar. O agora bispo de Winchester, Stigand, hábil e prudente, conseguiu evitar a guerra civil, mas o rei viu desertar para o campo do seu adversário alguns dos seus mais próximos. Uma assembleia dos grandes do reino, durante a qual o conde parece ter feito uma intervenção bastante teatral, acabou por apaziguar os ânimos: Godwin foi feito novamente conde de Wessex e a rainha Edite regressou à corte; o arcebispo de Canterbury, Roberto, foi afastado (sendo substituído por Stigand), e a família Godwin, no seu conjunto, foi totalmente reabilitada; Haroldo, por exemplo, recuperou o condado de East Anglia, que perdera para Alfgar, o filho de Leofric da Mércia. A ascensão de Haroldo foi particularmente espetacular, pois o irmão mais velho, Sven, que chegara a ter sob o seu controlo Oxford, Gloucester, Hereford e o Somerset, afundara-se numa carreira sombria: em 1046, no regresso de uma expedição a Gales, seduzira e raptara a abadessa de Leominster e caíra em desgraça, sendo forçado a exilar-se na Dinamarca; quando tentou regressar, foi bem acolhido pelo primo Beorn (irmão de Sven II Estridsen da Dinamarca), mas acabou por matá-lo, pelo que foi proscrito e obrigado a refugiar-se na Flandres; em 1050, foi perdoado, graças à intervenção do pai e do bispo de Worcester, mas partiu em peregrinação a Jerusalém e acabou por falecer em Constantinopla, em 1052, quando regressava dessa viagem aos lugares santos.

Deste modo, em 1052, Haroldo Godwinson atingira uma posição de especial relevo no seio da família Godwin, que dominava cada vez mais a Inglaterra. A Crónica Anglo-Saxónica, na entrada relativa ao ano de 1052, diz que o pai "Godwin tinha alcançado uma tal reputação que parecia reinar sobre o monarca e sobre toda a Inglaterra; os seus filhos eram condes e favoritos do rei, a sua filha era esposa do monarca" (in Mogens Rud, p. 21). Em março de 1053, faleceu o conde Godwin, durante uma refeição em plena corte régia, e, assim, Haroldo subiu ao topo da hierarquia familiar, tornando-se conde de Wessex. Enquanto isso, a East Anglia passou para as mãos de Gyrd; a região do Kent ficou entregue a Leofwine, que entretanto foi feito conde de um novo território no sudeste de Inglaterra, com 
epicentro em Londres; e, em 1055, à morte de Siward, Tostig Godwinson tornou-se conde da Nortúmbria, tendo compensado pela sua boa relação com o monarca da Escócia, Malcolm Canmore, as resistências com que os barões nortistas o acolheram. Dito por palavras mais simples, só a Mércia (nas mãos de Leofric e, a partir de 1057, nas de seu filho Alfgar) escapava ao domínio dos Godwin! Não contente, Haroldo ainda anexou o Herefordshire, na fronteira sul com Gales. Quando tomou posse do condado da Mércia, em 1062, Edwin (filho do falecido Alfgar) bem podia desabafar que tinha um vizinho poderosíssimo e sob cuja influência teria de se habituar a viver...

Esta evolução política teve reflexos dramáticos na capacidade governativa de Eduardo, que a partir de 1052 parece ter-se dedicado sobretudo a duas atividades: a religião e a caça. Coube-lhe mandar construir a mítica igreja de São Pedro, na ilha de Thorney, num lugar especialmente bonito entre o rio Tamisa e uma zona de campos abertos a oeste de Londres, depois conhecida como abadia de Westminster (minster significa "igreja monástica", ou "catedral"). Esta decisão parece ter resultado de uma penitência que o monarca impôs a si próprio por não ter cumprido, devido à idade avançada, a sua promessa de ir em peregrinação à Terra Santa. Por uma dessas ironias em que a História é fértil, a abadia ficaria concluída e seria consagrada escassos dias antes do falecimento do seu patrono, que seria inumado atrás do altar principal. Devido ao seu empenhamento nas matérias e nos ideais religiosos, este rei, que nunca teve filhos e que passa por nunca ter consumado o seu casamento com Edite, em sinal de castidade, ficaria para sempre conhecido pelo nome de Eduardo "o Confessor".

Se Eduardo preferia a oração e as caçadas, para governar e administrar o reino de Inglaterra, a partir de 1053, havia, sobretudo, Haroldo Godwinson, que a generalidade das fontes apresenta como um autêntico regente e subregulus (isto é, "vice-rei"). Louro, alto, atraente, amado e admirado por muitos (explica a Vita Edwardi Regis, uma biografia anónima de Eduardo "o Confessor" produzida por volta de 1067 por um clérigo que servia a rainha Edite), Haroldo viveu durante muitos anos à la danoise com a bela Edite "colo de cisne", uma amante que lhe deu pelo menos quatro filhos: três rapazes (que após Hastings seriam bem acolhidos na corte da Dinamarca pelo rei Sven II Estridsen) e uma menina chamada Gyda, que haveria de casar com o grão-duque de Kiev. 
Haroldo Godwinson e os seus irmãos estão diretamente ligados a alguns dos maiores sucessos obtidos durante o reinado de Eduardo "o Confessor". O rei da Escócia, Malcolm Canmore, afeiçoado a Tostig Godwinson, veio à corte de Londres reconhecer a supremacia de Eduardo e casou com uma filha de Eduardo "o Exilado", Margarida. Mas o governo de "o Confessor" também promoveu expedições militares bem-sucedidas contra o País de Gales, nas quais Haroldo Godwinson participou ativamente com um eficaz raide lançado em 1055. O príncipe de Gales, Gruffyd ap Llywelyn, tinha saqueado Hereford, mas Haroldo cercou a cidade com um fosso largo e profundo e fortificou-a com portas e barreiras, evitando males maiores; este foi, talvez, o primeiro sinal da grande capacidade militar do (agora) mais velho dos Godwin. Conta-se que, quando o rei Eduardo encontrou o príncipe de Gales, este o carregou aos ombros, em sinal de submissão. Porém, em 1063, Gruffyd desencadeou alguns raides contra a Mércia e Haroldo avançou de novo para o punir. Também aqui o valido de "o Confessor" se saiu bem: nesta segunda invasão das terras de Gales, Haroldo contou com o apoio do seu irmão Tostig, o que lhe permitiu coordenar um ataque concêntrico, naval e terrestre, que redundou na pilhagem da capital galesa, Rhuddlan, no saque do palácio do príncipe e no incêndio da sua frota. Os Galeses submeteram-se, mas Gruffyd conseguiu escapar por mar; no entanto, os seus próprios súbditos acabaram por o matar em Snowdonia e entregaram a cabeça a Haroldo, que a remeteu a Eduardo "o Confessor" como troféu do seu triunfo no País de Gales. Os irmãos de Gruffyd juraram lealdade ao rei e ao seu principal valido e dividiram entre si as terras que tinham pertencido a Gruffyd.

Em 1065, dar-se-ia uma revolta na Nortúmbria com consequências muito importantes para a continuação da nossa história. Como já referimos, Tostig Godwinson era, desde há uma dezena de anos, o conde desta região do norte de Inglaterra; porém, nunca tinha sido bem aceite pelas forças locais. No outono desse ano, aproveitando mais uma das ausências do seu conde, que andava à caça com o rei Eduardo (que parece que lhe era muito afeiçoado, tal como a rainha: a irmã Edite), 200 grandes camponeses da Nortúmbria, liderados por alguns thegns, revoltaram-se, ocuparam York e mataram todos os apoiantes de Tostig que encontraram (tanto ingleses 
como dinamarqueses, incluindo os seus guardas pessoais, os bousecarls Amund e Ravenswart). Os rebeldes - que se queixavam de tributos pesados, do confisco de terras e de sucessivos roubos à Igreja - apoderaram-se do tesouro condal, assaltaram o armazém de armas e ousaram proclamar um novo conde: Morcar, um irmão mais novo do conde Edwin da Mércia (ou seja, outro neto do velho valido de Cnut, o conde Leofric)! Um exército rebelde, que reunia tropas da Mércia e do País de Gales limítrofe, marchou para sul, sob a liderança de Morcar, atravessando grande parte da Inglaterra em claro desafio às autoridades.

Tostig não reagiu, contando talvez com o apoio de Eduardo e do irmão Haroldo. O monarca ordenou a este que contivesse a revolta pela força, mas o mais velho dos Godwin optou por negociar com os rebeldes, que entretanto se entregavam a pilhagens e devastações. Em Oxford, tiveram lugar difíceis conversações, tendo Haroldo acabado por propor ao rei que reunisse um witenagemot (isto é, uma reunião dos principais conselheiros reais), onde lhe sugeriu que reconhecesse Morcar como novo conde da Nortúmbria e que banisse Tostig... Eduardo, fragilizado, aceitou e, como é fácil de entender, esta deliberação separou para sempre os dois irmãos Godwin. Profundamente amargurado, Tostig partiu para a Flandres (recordemos que ele era casado com uma meia-irmã do conde Balduíno V, Judite), onde passou o inverno e onde de imediato parece ter começado a intrigar contra o irmão Haroldo. Não obtendo grande sucesso junto de Balduíno, Tostig virou-se então para o rei da Noruega, Harald III Sigurdsson, mais conhecido por Harald Hardrada (ou seja, "o Severo"). Este era um homem de estatura gigantesca e que as Sagas escandinavas consideram, devido à sua extraordinária carreira militar em diversas partes do mundo (na Noruega, na Suécia, na Rússia, na Sicília, na Bulgária e até em Bizâncio, onde chegou a comandar a célebre Guarda Varanguiana), como "o maior guerreiro debaixo do Sol".

Em 1064, entre a campanha no País de Gales e a revolta da Nortúmbria, Haroldo Godwinson foi à Normandia, numa viagem ainda hoje discutida pelos historiadores e que tem enorme importância para a compreensão dos acontecimentos de 1066. Não se sabe exatamente o que Haroldo terá ido fazer à Normandia, mas as principais fontes normandas (Guilherme de Poitiers e Guilherme de Jumièges) alegam que ele ali foi expressamente 
enviado pelo rei Eduardo para confirmar com o seu juramento, enquanto homem mais importante de Inglaterra a seguir ao monarca, a promessa que "o Confessor" teria feito a Guilherme, em 1051 ou 1052, de que seria ele, o duque da Normandia, a suceder-lhe no trono de Inglaterra. Eduardo já estava bastante idoso e debilitado, não tinha filhos e teria querido acautelar deste modo a sua sucessão, optando por beneficiar o maior barão da Normandia (terra que lhe dizia muito) e que ainda era, vagamente, seu parente. Como caução dessa velha promessa, o duque conservava ainda em seu poder Wulfnot Godwinson (o irmão mais novo de Haroldo) e Hakon (seu sobrinho), cuja libertação o conde iria, talvez, tentar durante a sua visita, na sequência do seu compromisso pessoal para com Guilherme.

A história tem alguma coerência, mas não temos meio de a confirmar. E subsistem diversas dúvidas, uma vez que parece estranho que Haroldo renunciasse de moto próprio à possibilidade de ser ele mesmo, o homem mais poderoso de Inglaterra e que há muito colaborava já no governo do reino, a suceder a Eduardo (de quem, aliás, era cunhado). Haroldo quereria, simplesmente, libertar o irmão e o sobrinho? Ou será que teria ido à Normandia por sua iniciativa, e não a mando do rei, no fito de garantir o apoio de Guilherme à sua própria candidatura, em troca de algumas promessas que pudessem parecer ao duque suficientemente tentadoras? $\mathrm{O}$ compromisso entre Eduardo e Guilherme, estabelecido em 1051 ou em 1052, existiria mesmo? E o conde de Wessex teria conhecimento dele?

Certo é que Haroldo aportou (talvez inadvertidamente, em resultado de maus ventos) no Ponthieu (na atual Picardia, mas muito perto de Saint-Valéry, na linha do rio Somme) e foi imediatamente preso pelo respetivo conde, chamado Guido, um barão que Guilherme havia obrigado a submeter-se-lhe pela força das armas e que resolveu aqui fazer uso do seu direito de saque sobre naufrágios. Ao saber da detenção do ilustre conde de Wessex, Guilherme enviou mensagens a Guido para que o libertasse de imediato; o conde assim fez, para evitar incorrer na fúria do duque ou talvez em troca de uma boa recompensa, e parece que escoltou pessoalmente Haroldo até à corte do duque, em Rouen. Tudo isto é representado na Tapeçaria de Bayeux, cuja narrativa começa exatamente com a viagem de Haroldo à Normandia, o que também é sugestivo. 


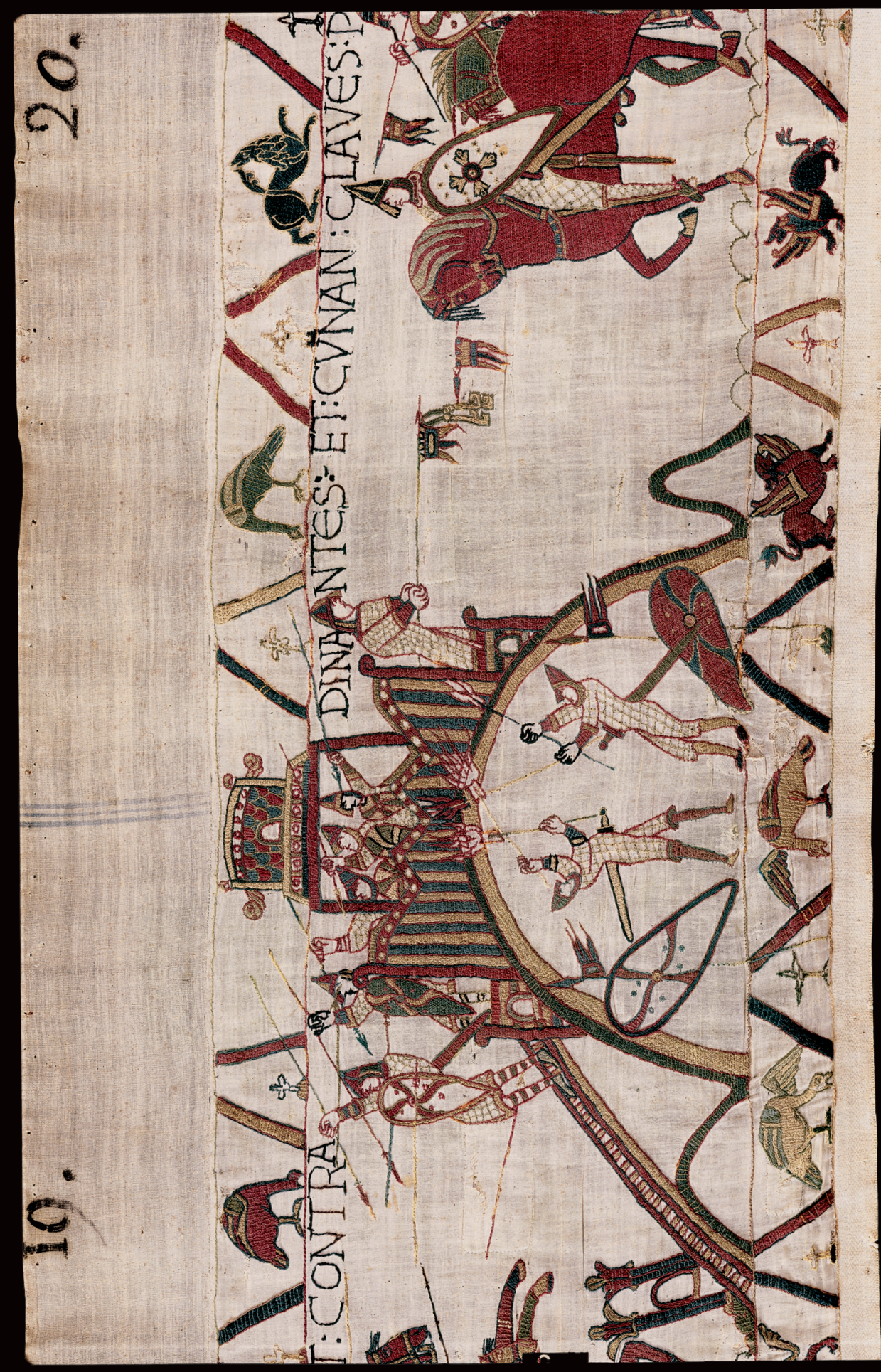


Em Rouen, Guilherme e Haroldo conversaram e conviveram largamente, posto o que partiram numa campanha militar conjunta contra um dos mais poderosos rivais da Normandia: o conde Conan da Bretanha. Depois de capturarem Dol, Rennes e Dinan (a tapeçaria representa de forma magnífica os castelos de mota destas localidades) e de forçarem Conan à rendição, Guilherme - um chefe militar já muito afamado - terá armado Haroldo cavaleiro, seguindo-se o regresso à Normandia. Aqui, durante uma assembleia reunida pelo duque em Bonneville-sur-Touques, Haroldo Godwinson terá prestado a Guilherme um juramento solene. A Tapeçaria de Bayeux, que exprime também o ponto de vista normando dos acontecimentos, ilustra este momento mostrando o conde de Wessex a jurar sobre dois grandes relicários, um debaixo de cada mão. Nunca saberemos o teor deste juramento, mas Guilherme de Poitiers reclama que Haroldo prometeu a Guilherme que faria tudo o que estivesse ao seu alcance para que o duque viesse a ser o sucessor de Eduardo no trono de Inglaterra. Segundo esta versão dos acontecimentos, Haroldo terá mesmo prometido ao duque fortificar e guarnecer a expensas próprias algumas praças do sul de Inglaterra pelas quais Guilherme terá mostrado particular interesse devido à sua posição estratégica, em especial Dover. Feito isto, e confirmados todos os bens pessoais dos Godwin por parte do duque (seria sobretudo isto que Haroldo pretendera obter com a sua viagem à Normandia?), uma das filhas de Guilherme (Adélia) terá sido prometida em casamento a Haroldo, que regressou a Inglaterra acompanhado do sobrinho Hakon. Quanto a Wulfnot, terá permanecido na Normandia como refém do compromisso do irmão mais velho para com o duque, o que também é revelador.

As fontes anglo-saxónicas ignoram esta viagem de Haroldo Godwinson à Normandia e omitem qualquer compromisso solene por parte do conde de Wessex em relação ao duque Guilherme II; no entanto, a generalidade dos estudiosos da batalha é de opinião de que, em 1064, Haroldo foi mesmo à Normandia e se encontrou com Guilherme, a quem prestou um juramento. Alguns admitem, contudo, que o terá feito sob coação, em resultado da sua condição de prisioneiro entregue pelo conde de Ponthieu ao duque normando, ou que se limitou a jurar fidelidade a Guilherme, que acabara de o armar cavaleiro. Em qualquer dos casos, é possível que, dada a forma desastrada como a visita começou, Haroldo Godwinson tenha ido além 
daquilo que seria o seu desejo inicial, tal como sugere a Vita Edwardi Regis, que insinua de forma vaga que Haroldo foi "demasiado generoso com juramentos". A menos que o mais velho dos Godwin pretendesse ludibriar o duque para mais facilmente o surpreender quando chegasse o momento decisivo da morte de Eduardo... Do que não restam dúvidas é de que a propaganda normanda tirou mais tarde bom partido da visita de Haroldo e do juramento por ele prestado em Bonneville. Curiosamente, na cena representada na tapeçaria, um dos elementos do séquito de Haroldo parece querer adverti-lo de algo, no momento em que este presta o seu juramento sobre os relicários; e o mais velho dos Godwin também não parece nada à vontade na cena que retrata a conversa entre ele e o velho rei Eduardo, logo após o seu regresso a Inglaterra.

Com a degradação da saúde do rei, que não deixava herdeiros diretos, a expetativa adensava-se relativamente à sua sucessão. Alguns autores (como Jim Bradbury) sugerem que o próprio Eduardo foi mudando de opinião nesta matéria, ao longo do seu reinado, jogando politicamente com o facto, tal como o fazem com o testamento alguns milionários modernos. A determinada altura, o monarca poderá ter-se arrependido da eventual promessa feita a Guilherme na época do exílio dos Godwin e poderá ter procurado uma alternativa dentro da família mais próxima: Eduardo "o Exilado", meio-sobrinho de "o Confessor" (uma vez que era filho do seu meio-irmão, Edmundo Ironside), poderá ter sido uma hipótese acarinhada pelo rei, que o mandou vir da Hungria em 1057; no entanto, desgraçadamente, ele faleceu assim que chegou a Inglaterra e antes mesmo de se encontrar com o tio! Consigo trouxera, porém, o filho Edgar (conhecido por "Etheling" em virtude de descender de Ethelred II), mas este tinha cerca de 5 anos quando o pai faleceu e, portanto, em inícios de 1066, à morte do rei Eduardo, não teria mais do que 14 ou 15 anos, não possuindo ainda títulos, nem domínios, nem séquito próprio. Havia também Rodolfo, um sobrinho de Eduardo (filho da sua irmã mais nova, Godgifu, e de Drogo, conde de Mantes), e parece que "o Confessor" terá igualmente pensado nele, fazendo-o conde de Hereford; no entanto, também morreu em 1057 e a hipótese, se existiu, gorou-se.

Neste cenário tão acidentado, é provável que Eduardo "o Confessor" tenha hesitado bastante entre Guilherme, que lhe recordava a Normandia, onde crescera e fora feliz, e Haroldo, que, sendo filho do seu velho rival 
e presumível assassino do seu irmão Alfredo, era contudo o seu principal valido, o irmão da estimada rainha e um homem de enorme autoridade em Inglaterra. Possivelmente, Eduardo terá dado esperança a ambos, em momentos diferentes, consubstanciando um comportamento dúplice que se repercutiu depois nos dramáticos acontecimentos de 1066.

Nas vésperas do Natal de 1065, Eduardo adoeceu gravemente, ao ponto de falhar a festa de consagração da 'sua' abadia de Westminster, realizada a 28 de dezembro. No seu leito de morte, rodeado pelos seus mais próximos, entre os quais a rainha Edite, o irmão desta (Haroldo Godwinson), o agora arcebispo de Canterbury, Stigand, e Roberto Fitz Wimarc (um homem de origem bretã ou normanda, que se estabelecera no Essex em 1052), Eduardo terá indicado Haroldo Godwinson como o seu sucessor preferido; o próprio Guilherme de Poitiers admite este facto no seu relato pró-normando dos acontecimentos, ao mencionar uma troca de mensagens entre Haroldo e Guilherme pouco antes da batalha de Hastings.

A 5 de janeiro de 1066 (data provável), Eduardo "o Confessor" exalou o seu último suspiro e foi velado e sepultado, logo no dia seguinte, na abadia de Westminster. De imediato, os grandes promoveram um witenagemot em Londres e elegeram Haroldo Godwinson como rei de Inglaterra, sob o nome de Haroldo II. Para o conjunto da Inglaterra, este parecia ser o menor dos males: para os sulistas, o conde do Wessex era o seu senhor natural; para os nortistas, como os irmãos Edwin (conde da Mércia) e Morcar (conde da Nortúmbria), era pelo menos um nobre conhecido e com o qual se haviam habituado a lidar (de certo modo, Morcar até devia o seu importante título à decisão de Haroldo de banir o irmão Tostig); para muitos dos restantes, Haroldo II seria provavelmente um risco menor do que Guilherme da Normandia, Sven II Estridsen da Dinamarca, Hardrada da Noruega ou o jovem e imberbe Edgar Etheling. Ainda assim, alguns dos normandos de que Eduardo se rodeara em Inglaterra e muitos dos escandinavos que aqui viviam e que recordavam com saudade os tempos de Cnut "o Grande" teriam decerto preferido uma outra solução.

Mas não houve tempo para mais. 'Rei morto, rei posto' e Haroldo II logo foi coroado, sem quaisquer incidentes e com a aparente concordância (explícita ou silenciosa) de todos os grandes de Inglaterra. A Crónica Anglo- 
-Saxónica explica que o subregulus Haroldo sucedeu a Eduardo conforme indicação deste e segundo a escolha dos principais do reino; e João de Worcester acrescenta que Haroldo II começou de imediato a produzir boa legislação e a proteger o reino por mar e por terra. Já para as fontes normandas, a coroação imediata traduziu uma pressa indecente, consumou o perjúrio de Haroldo e foi um gesto iníquo e até ilegal, uma vez que a cerimónia teria sido dirigida pelo arcebispo de Cantuária, Stigand, que estava sob a mira da Santa Sé por ter recebido o pallium episcopal (isto é, a estola de lã branca ornada de cruzes negras) das mãos do antipapa Bento X. Pressente-se que Guilherme foi apanhado um pouco de surpresa, mas quanto à ilegitimidade da cerimónia tudo leva a crer que Haroldo II se terá precavido e que a coroação terá sido presidida, isso sim, pelo arcebispo de York, Eadred. A Tapeçaria de Bayeux representa Haroldo II majestosamente sentado no seu trono, com a coroa na cabeça, o ceptro na mão direita e o globo na mão esquerda. Era o início de um novo reinado, um momento pelo qual Haroldo possivelmente esperara durante alguns anos (porventura desde a misteriosa viagem de 1064). Contudo, não estava escrito nas estrelas que aquele dia de janeiro de 1066 fosse o primeiro de muitos dias felizes para Haroldo Godwinson, rei de Inglaterra: a cena seguinte da tapeçaria representa um aglomerado de homens a olhar com espanto e algum temor para o céu, onde o artista representou um corpo celeste em chamas. Era o cometa Halley, que sabemos ter sido avistado em Inglaterra a 24 de abril de 1066 e que, segundo as fontes anglo-saxónicas, terá brilhado nos céus da velha Bretanha durante uma semana. Um presságio, certamente, e um mau presságio, tendo em conta os acontecimentos que se seguiram em Inglaterra e a própria expressão de terror que o artista da tapeçaria coloca no rosto de Haroldo, logo que lhe dão a notícia de tão estranha aparição...

\section{A Normandia de Guilherme II}

Como é bem sabido, os Vikings não atacaram apenas a Inglaterra. Desde pelo menos os inícios do séc. Ix que eles se interessaram também pela Gália, e o próprio Carlos Magno (768-814) já teve de se haver com eles. 
Provavelmente - devido a algumas mutações económicas e sociais ocorridas na Escandinávia e ainda mal conhecidas dos historiadores, e não apenas por sede de ouro ou de aventura -, grupos de noruegueses, de dinamarqueses e de suecos começaram a atacar a Gália em raides marítimos fulgurantes, tornados possíveis pelos seus magníficos barcos: os drakkars ou os snakkars (com dragões ou serpentes, respetivamente, a ornamentar a proa), com comprimentos entre 20 e 25 metros, capazes de transportar entre 40 e 100 remadores e podendo navegar à vela ou a remos, consoante os ventos e as marés. Quando aportavam, os Vikings roubavam cavalos e procediam a raides terrestres em que os principais trunfos eram a surpresa ou o ardil.

Os Francos lidaram mal com esta nova ameaça, pois a sua estratégia militar baseava-se mais na ofensiva de um exército bem equipado e na defesa de fronteiras estáticas, organizadas em "marcas"; ora, perante os Nordmen (os Normandos, literalmente os "homens do Norte") isso era ineficaz. Para mais, o comando sofreu bastante com as divergências entre os vários soberanos e os seus descendentes, especialmente a partir da época de Luís "o Pio" (814-840), o filho e único herdeiro de Carlos Magno. Só os pontos fortificados ou as paliçadas de madeira construídas sobre as motas (pequenos outeiros de terra feitos artificialmente) conseguiam resistir pois, de início, os invasores não eram assim tão experientes na guerra de cerco.

Em 864, Carlos "o Calvo" (rei da França ocidental) exigiu que os condes construíssem e vigiassem as fortalezas, mas a defesa organizou-se sobretudo ao sabor de iniciativas locais. Os territórios mais tocados foram os que bordejavam o Mar do Norte e a Mancha, a partir de onde os invasores subiam os vales do Escaut, do Saône e do Sena, assim como os da fachada atlântica, desde os quais atacavam os vales do Loire e do Garona.

Tal como na Inglaterra anglo-saxónica, a repetição dos raides provocava uma grande insegurança. Atraídos pelo ouro e pela prata, os Vikings pilhavam as abadias ricas (p. ex.: Jumièges e Saint-Wandrille, na Normandia) e massacravam os bispos (como o de Nantes, cuja capital foi incendiada). A população, tomada de pânico, fugia.

Assim como em Inglaterra, registou-se uma clara evolução na gradação das expedições nórdicas contra a Gália: do simples raide (com repartição imediata do despojo), os Vikings passaram à conquista e ocupação do território. A França ocidental resistiu o melhor que pôde aos assaltos normandos, 
mas, instalados nas embocaduras dos rios, os Vikings conseguiram penetrar até ao coração do reino de Carlos "o Calvo"; Paris foi atacada quatro vezes em menos de um século; e, em 857, os nórdicos incendiaram a cidade e exigiram pesadas somas de prata à abadia de Saint-Denis; mais tarde, seguiram-se outros tributos e, à maneira do que sucedera em Inglaterra, os reis de França acederam, de modo a limitar os estragos.

Em finais do séc. IX, os ataques multiplicaram-se, tirando partido da crise interna na França ocidental (à morte de Luís "o Gago", filho de Carlos "o Calvo"); chegaram novos contingentes, e os Escandinavos penetravam cada vez mais profundamente em terras longe do mar, onde tentavam estabelecer as suas bases; a região do Escaut foi duramente pilhada.

Em 885, a situação tornou-se mesmo muito grave. As forças normandas concentraram-se no baixo Sena para atacar Paris e a cidade resistiu estoicamente durante mais de um ano, defendida pelo conde de Paris, Eudo, filho do magnate Roberto "o Forte". Carlos "o Gordo", elevado ao trono em 884, interveio, mas viu-se obrigado a comprar a partida dos nórdicos através de um tributo. Ainda assim, os Vikings continuaram na região, perpetuando a ameaça.

Finalmente, em 911, pelo Tratado de Saint-Clair-sur-Epte, o rei da França ocidental, Carlos III “o Simples” (898-929), reconheceu a um dos chefes vikings de origem norueguesa, Rolf (Hrolf Ganger, também conhecido por Rollo), o direito a ocupar o território em que ele se queria instalar: a província entre a Bretanha e a Flandres, uma das regiões mais ricas de toda a França! Em contrapartida, Rolf e os seus homens comprometeram-se a aderir ao cristianismo e a proteger o seu território, a partir de agora chamado "Normandia", contra os raides futuros de outros Vikings e até contra a cobiça dos Bretões da antiga Armórica. Para selar o acordo, uma filha de Carlos III foi prometida a Rolf em casamento.

De início, o território dos Normandos na Gália estava ainda confinado à região de Rouen, ou seja, a uma área restrita à volta do Sena (aquilo a que poderíamos chamar uma Normandia 'superior' ou 'oriental'), mas o instinto e a capacidade guerreiras de Rolf e dos condes (mais tarde, duques) que se lhe seguiram encarregaram-se de o alargar consideravelmente: em 933, já o limite poente da Normandia, terra muito rica em cereais e em fruta, beijava as duas margens do rio Couesnon, chegando até Dol. 
O caso da fixação dos Normandos em França é interessante pois, dos muitos povoados vikings estabelecidos no litoral oeste do continente europeu, só a Normandia sobreviveu longamente sob uma dinastia nórdica e, portanto, só ela teve possibilidade de se desenvolver como uma unidade política forte (embora nunca tenha chegado a constituir propriamente um reino, já que reconhecia o monarca da França).

A Rolf, um gigante norueguês que parece ter sido um aventureiro exilado por Haroldo Fairhair (rei da Noruega entre 900 e 933) e que circulara já pela Escócia, pela Nortúmbria e pela Irlanda, levando uma verdadeira vida de viking, sucederam vários outros chefes notáveis. Primeiro, o seu filho Guilherme "Espada Longa" (entre 924 e 942); e, depois do assassinato deste, o seu neto Ricardo I (942-996), cuja menoridade deu azo a desordens e sobressaltos políticos de que o jovem conde acabou por se sair bem graças à ajuda do rei da França ocidental e do dux Hugo "o Grande", descendente de Roberto “o Forte” e o senhor mais poderoso da Gália. Mais tarde, quando o rei e o $d u x$ quiseram derrubar o condado, Ricardo I mostrou ser resistente e determinado, o que lhe valeu o cognome de "Sem Medo". Como já sabemos, casou com Gunnor e o casal tornou-se uma lenda e uma referência para os Normandos de 1066. Quando se deu em França a transição da dinastia carolíngia para a dinastia capetíngia, Ricardo I foi dos primeiros a reconhecer o rei Roberto Hugo Capeto (987-996), filho de Hugo "o Grande". A ele se deve também o novo ímpeto do cristianismo na Normandia, do que constitui bom exemplo a dinamização do célebre mosteiro do Monte Saint-Michel.

Seguiu-se o duque Ricardo II (996-1026), o protetor e educador de Eduardo "o Confessor" durante a juventude deste, que assumiu o título ducal em ano de revolta camponesa, duramente reprimida. Ao longo do seu mandato, registou-se um crescimento económico significativo (em especial com o alargamento da área de interesses ao mundo escandinavo), e a Normandia ganhou em estabilidade. Vários autores têm notado o progressivo 'afrancesamento' da região nesta época (língua, cultura, ideias políticas, sistema administrativo), o que traduz a boa integração dos nórdicos no seu território de acolhimento e é o resultado natural dos matrimónios contraídos entre Normandos e Franceses. Ricardo II (que, recordemos, era irmão de Ema, a mãe de Eduardo "o Confessor") casou duas vezes (para 
além da sua breve ligação à desgraciosa Estride, irmã de Cnut): a primeira, com uma filha do conde de Rennes, que lhe deu dois filhos (Ricardo III e Roberto I), que sucederiam ao pai; a segunda, com a normanda Papia, de que resultaram Guilherme de Arques e Mauger, uma verdadeira 'segunda família' que geraria muitos incómodos políticos ao futuro duque Guilherme II. A vontade de afirmar a superioridade do conde de Rouen em relação aos outros governantes locais (os condes de Mortain, de Ivry, de Évreux e de Eu, entre outros) levou à criação, sob Ricardo II, do título de "duque da Normandia". Nesta altura, surgiram também os viscondes, que contudo não eram mais do que representantes do rei, e não poderes autónomos; entre 1020 e 1035, estima-se que existissem perto de vinte viscondes na Normandia, o que revela bem o crescimento da estrutura de governo neste ducado.

Ricardo III sucedeu ao pai em 1026, mas faleceu logo em 1027, porventura assassinado pelo irmão e sucessor, Roberto I (1027-1035). No governo deste duque, talvez o líder mais fraco de todos quantos descenderam da linhagem de Rolf, verificou-se uma deterioração das relações externas do ducado, e cresceu a desordem interna. Para agravar a situação, em finais de 1034 ou já em 1035, Roberto I, que nessa altura contava com apenas 25 anos, resolveu convocar um conselho dos seus barões, a quem declarou que ia partir em peregrinação a Jerusalém; pediu-lhes então que jurassem fidelidade ao pequeno Guilherme, um filho bastardo que tivera em 1027 ou em 1028 da bela Herlève de Falaise; os barões acederam, mas decerto logo afiaram as facas, prevendo uma sucessão complicada com um menino tão pequeno (Guilherme teria entre 7 e 9 anos) e, ainda por cima, bastardo...

Roberto I viajou mesmo para a Terra Santa (de onde nunca mais voltou, devendo ter falecido logo em julho de 1035, em Niceia), e Guilherme, que terá nascido no próprio castelo de Falaise, ficou sob a proteção de dois grandes (o rei de França, Henrique I, e Alan da Bretanha, primo do duque Roberto) e foi entregue aos cuidados de uma série de oficiais da confiança pessoal do seu pai: a Gilberto de Brionne, que ficou por seu tutor; ao senescal (administrador) Osberno, também ele primo de Roberto; e a Turoldo, o seu precetor. Curiosamente, na altura da partida de Roberto I para a Terra Santa, o duque fez o jovem e fiel conde Herluíno de Conteville prometer-lhe que, caso morresse durante a peregrinação, Herluíno casaria com Herlève de Falaise, a mãe de Guilherme. 
Em 1037, chegou a Rouen a notícia da morte de Roberto I. Tal como o previsto, Herluíno casou com Herlève, com quem talvez já vivesse. Desta união resultaram Odão (futuro bispo de Bayeux e provável mandante da fabulosa tapeçaria) e Roberto (que se tornaria conde de Mortain). Estes dois meios-irmãos de Guilherme viriam a ser peças-chave do grande projeto normando de conquista e ocupação da Inglaterra.

O pior foi que, logo após a confirmação da morte do duque, poucos aceitaram a sua sucessão pelo pequeno bastardo Guilherme, então com apenas 9 ou 10 anos. Entre 1037 e 1040, grassou na Normandia uma tremenda instabilidade, com revoltas camponesas, grandes divisões no seio da aristocracia, guerras ferozes entre os diversos barões instalados nas suas fortalezas privadas (incluindo os que lhe haviam prometido fidelidade) e ataques violentos contra o jovem duque e contra aqueles que se lhe mantinham leais. Basta lembrar que, neste período, foram assassinados o seu tutor Gilberto de Brionne, depois o precetor Turoldo (apunhalado por um desconhecido) e, a seguir, o senescal Osberno (liquidado no castelo de Vaudreuil com o pequeno a dormir ali por perto). Em 1040, o próprio Alan da Bretanha, tio de Guilherme, seria assassinado. A contestação ao jovem duque fazia-se de um misto de avidez pelo poder (no que se distinguiram os seus tios Guilherme de Arques e Mauger) e de troça e desprezo, já que se tratava de um filho ilegítimo e, além disso, nascido do ventre de uma filha de um modesto curtidor de peles de Falaise... A situação tornou-se tão grave para o jovem - que, por diversas vezes, escapou por pouco de ser assassinado - que os que ainda o protegiam optaram por escondê-lo entre 1040 e 1045 ou 1046, entregando-o, segundo alguns historiadores normandos, à guarda de uns camponeses-lenhadores. Terá sido neste ambiente que o herdeiro ducal cresceu entre os seus 12 e 18 anos, aproximadamente!

Por volta de 1046, sentindo-se forte e preparado para enfrentar os adversários, Guilherme, já com 18 ou 19 anos, saiu da clandestinidade a que tinha sido forçado e decidiu passar à ação. A sua caminhada, tudo o indica, foi fulgurante: começou por reconquistar Falaise e o seu castelo, ocupado por um tal Torstin Goz, filho de Ansfred "o Dinamarquês”. A seguir, deu-se a conspiração do primo Guido de Brionne (filho de Reinaldo da Borgonha), que projetava matá-lo para depois se apoderar do título ducal: 
avisado por um jogral, escapou in extremis. Por esta altura, o rei Henrique I, que tinha aproveitado o clima de intrigas e de conspirações para alargar a sua influência ao leste da Normandia, decidiu apoiar Guilherme, conforme prometera ao pai dele e como seu suserano; juntos, obtiveram uma vitória esmagadora sobre os rebeldes na batalha de Val-ès-Dunes, nas margens do rio Dives (entre Caen e Falaise). O combate foi sangrento, e a prestação de Guilherme levou o monarca a armá-lo cavaleiro no próprio campo de batalha. O jovem perdoou a quase todos os conspiradores que sobreviveram, incluindo ao primo Guido de Brionne, que regressou à Borgonha.

Com a situação interna já mais consolidada, Guilherme, em 1051 ou em inícios de 1052, terá então feito a sua visita a Eduardo "o Confessor", em Inglaterra, da qual já demos conta. Em 1053, casou com Matilde, uma filha do conde Balduíno V da Flandres, sobrinha daquela Judite que casou com Tostig Godwinson. O interesse estratégico deste matrimónio é evidente, já que a Flandres era um dos mais poderosos vizinhos da Normandia, mas o casamento (celebrado na capela de Nossa Senhora, no castelo normando de Eu) começou por ser invalidado pelo papa Leão IX, que alegava que os noivos eram parentes em quinto grau. Guilherme e Matilde não recuaram e o sumo pontífice lançou sobre a Normandia o terrível interdito - a pena eclesiástica que privava os fiéis de certos bens espirituais, como sacramentos, ofício divino ou sepultura religiosa. O assunto só se resolveu com o papa Nicolau II e com o Concílio de Latrão, graças à influência do prior da abadia de Bec, Lanfranc, um dos melhores amigos e conselheiros de Guilherme, tanto na Normandia como, mais tarde, em Inglaterra. No entanto, a bênção papal teve um preço: o casal deveria fundar hospícios para velhos, doentes e cegos em Rouen, Caen, Bayeux e Cherbourg, e deveria mandar construir e manter, a expensas próprias, uma abadia para homens e outra para mulheres. Do casamento de Guilherme com Matilde nasceriam oito filhos: quatro rapazes (Roberto Courteheuse, Ricardo, Guilherme "o Ruivo" e Henrique, tendo os dois últimos sucedido ao pai) e quatro meninas (Constança, Adelaide, Ágata e Adélia, das quais uma foi prioresa da abadia fundada pela mãe em Caen, duas casaram com nobres franceses e a outra, Ágata, faleceu relativamente cedo, depois de ter servido de peão no xadrez político da sucessão real em Inglaterra). 
Guilherme é representado 17 vezes na Tapeçaria de Bayeux. Se o artista contemporâneo foi fiel, o duque não era um homem de tipo nórdico, apesar de ser alto e forte: tinha uma fisionomia quase meridional, com olhos e cabelo escuros, perfil de tipo grego, regular, queixo arredondado e um ar bastante enérgico. Um monge (anónimo) de Caen, que alega tê-lo conhecido pessoalmente e que traça o seu retrato pouco tempo depois da sua morte (em 1087), apresenta o duque como um homem grande, seco de carnes, enérgico e corajoso, sóbrio nos costumes (p. ex., na bebida) e de forte disciplina cristã, um indivíduo de palavra fácil e persuasiva, com uma voz um pouco gutural.

Foi justamente com esta energia e com esta voz de comando que Guilherme, a partir do seu casamento com Matilde, começou a construir uma verdadeira máquina de guerra com a qual decidiu atacar os seus vizinhos; dessa forma, o duque dava continuidade à tradição normanda de alargamento das fronteiras do território outorgado a Rolf e aos seus sucessores. A sua agressividade começou a inquietar seriamente os ávidos rivais da Bretanha, do Maine e do condado de Anjou (a sul da Normandia), que solicitaram a intervenção do rei de França. Alarmado com a força dos Normandos, Henrique I juntou-se aos inimigos do duque, mas este resistiu: cercou e destruiu fortalezas privadas, enfrentou os tios (Guilherme, conde de Arques, e Mauger, arcebispo de Rouen) e não tremeu diante do rei de França e do conde de Anjou, Godofredo Martel. Logo em 1053, homens de armas ao serviço de Guilherme, sob a liderança de Gualter Giffard (que combateria ao lado do seu duque em Hastings), venceram Henrique I, que tentava libertar Arques, na batalha de Saint-Aubin-sur-Scie. Na sequência deste combate, em que os Normandos recorreram à tática da retirada simulada (um pormenor a reter), Guilherme de Arques teve de se submeter e foi exilado. No ano seguinte, deu-se uma nova rebelião e outra grande vitória militar do duque, em Mortemer, da qual resultou o aprisionamento do conde Guido de Ponthieu (o mesmo que prenderia Haroldo Godwinson em 1064), que teve de lhe jurar fidelidade.

À medida que ia travando estes combates, Guilherme ia compondo o seu núcleo duro de fiéis, que integrava sobretudo familiares (como os meios-irmãos Odão, que veio a ser bispo de Bayeux, e Roberto, conde de Mortain) e também amigos feitos no seio da nobreza normanda, como Guilherme Fitz Osbern (neto do conde de Ivry), Rogério de Montgomery 
(visconde de Hiémois), Guilherme de Varenne, Rogério de Beaumont, Roberto, conde de Eu (irmão do bispo de Lisieux), Ricardo, conde de Évreux (filho do arcebispo Roberto), e o visconde Hugo II de Montfort. Foi sobretudo com estes homens que Guilherme ganhou e expandiu o seu ducado, e foi também com eles que, em 1066, se fez ao mar para a grande aventura da conquista da Inglaterra.

Pouco a pouco, os sucessos de Guilherme e dos seus pares iam cimentando o seu prestígio e colocando sob o controlo do ducado cada vez mais grandes e pequenos. O rei de França bem que denunciara o antigo laço de suserania, vindo do tempo de Rolf, para tentar submeter a Normandia com o apoio do conde de Anjou. Uma vez mais, os dois invadiram a Normandia com um forte exército e provocaram perdas importantes; de novo Guilherme e os seus magníficos reagiram, infligindo, em 1057, em Varaville (junto ao rio Dives), uma humilhante derrota a Henrique I e a Godofredo Martel, que também sonhava conquistar o Maine e a Bretanha. Nesta batalha, os Normandos apanharam o adversário a meio da travessia do curso de água, num vau, tendo atacado de forma fulgurante com cavalaria e com arqueiros (um outro pormenor a não perder de vista).

A estratégia de Guilherme, que sabia que o ataque é a melhor forma de defesa, deu os seus frutos e foi recompensada pela deusa Fortuna: em 1060, ocorreu a morte quase simultânea de Henrique I de França e de Godofredo Martel de Anjou, os seus arquirrivais. Em ambos os casos, o decesso traduziu-se num contexto extremamente vantajoso para Guilherme II da Normandia: o novo rei de França, Filipe I, tinha apenas 8 anos de idade; e, entre os Angevinos, a sucessão de Godofredo Martel gerou um contencioso entre os respetivos sobrinhos, Godofredo IV, "o Barbudo", e Foulque IV, "o Carrancudo".

Deste modo, Guilherme ficou com as mãos livres para avançar para projetos mais ousados. Em 1063, conquistou o Maine, que durante algum tempo seria incorporado na Normandia; no ano seguinte, na companhia de Haroldo Godwinson, como já dissemos, atacou a Bretanha, numa campanha militar que a Tapeçaria de Bayeux mostra ter sido feita a cavalo e que obrigou o conde Conan a render-se e a entregar ao duque normando, na ponta de uma lança de armas, as chaves da fortaleza de mota de Dinan (uma cena lindamente representada no bordado: vide p. 223). 
Deste modo, quando chegamos a 1066, o duque está nas condições ideais para enfrentar o desafio da candidatura ao trono de Inglaterra. Como disse Stephen Morillo, a campanha de Guilherme na velha ilha anglo-saxónica foi uma conjugação feliz de oportunidade, de motivo e de meios. Dez anos antes, não teria podido empreender uma tal aventura, manietado que estava pelos problemas internos do seu ducado; dez anos depois, seria demasiado velho para se lançar nela. Em 1066, todos os santos favoreceram a decisão de Guilherme de atacar a Inglaterra: a autoridade ducal estava perfeitamente consolidada na Normandia; as ameaças externas estavam controladas (incluindo a Flandres, em resultado do casamento com Matilde); e a morte de Eduardo "o Confessor" fornecia o pretexto ótimo para avançar. Só faltava a aprovação papal do projeto e mesmo isso se conseguiu rapidamente: na sequência do envio de emissários normandos a Roma, acusando Haroldo Godwinson de perjúrio e alegando uma coroação ilegítima do rei inglês, Alexandre II (carente de bons apoios militares continentais) solidarizou-se com a causa normanda e enviou a Guilherme a bandeira papal, sob cuja sombra os Normandos se fizeram à Mancha.

Não foi, todavia, tão fácil quanto isso a partida da frota ducal a caminho de Inglaterra. Segundo Guilherme de Poitiers, a notícia da coroação de Haroldo II caiu como uma bomba na corte normanda. A Tapeçaria de Bayeux mostra a chegada de um barco inglês portador da má nova e sugere uma reunião imediata do conselho ducal, com o bispo Odão de Bayeux a desempenhar um papel muito ativo. Guilherme de Jumièges acrescenta que, ao saber desta "louca política" dos Ingleses, o duque enviou mensageiros a Inglaterra, intimando Haroldo a recuar. Não tendo obtido satisfação, os dois cronistas explicam que Guilherme passou de imediato aos preparativos de um ataque em força a Inglaterra. Guilherme de Poitiers conta que o duque tratou de reunir navios, provisões e homens de armas, em cujo recrutamento se empenhou fortemente. A tapeçaria documenta a construção de alguns navios e a forma como estes foram sendo carregados com cavalos, com vitualhas, com barris de vinho e com armamento variado: lorigas para proteção do tronco (que se adivinha serem bastante pesadas), capelinas (proteções de cabeça, em formato cónico e com nasais para defesa da cana do nariz), espadas, lanças e machados de guerra. 


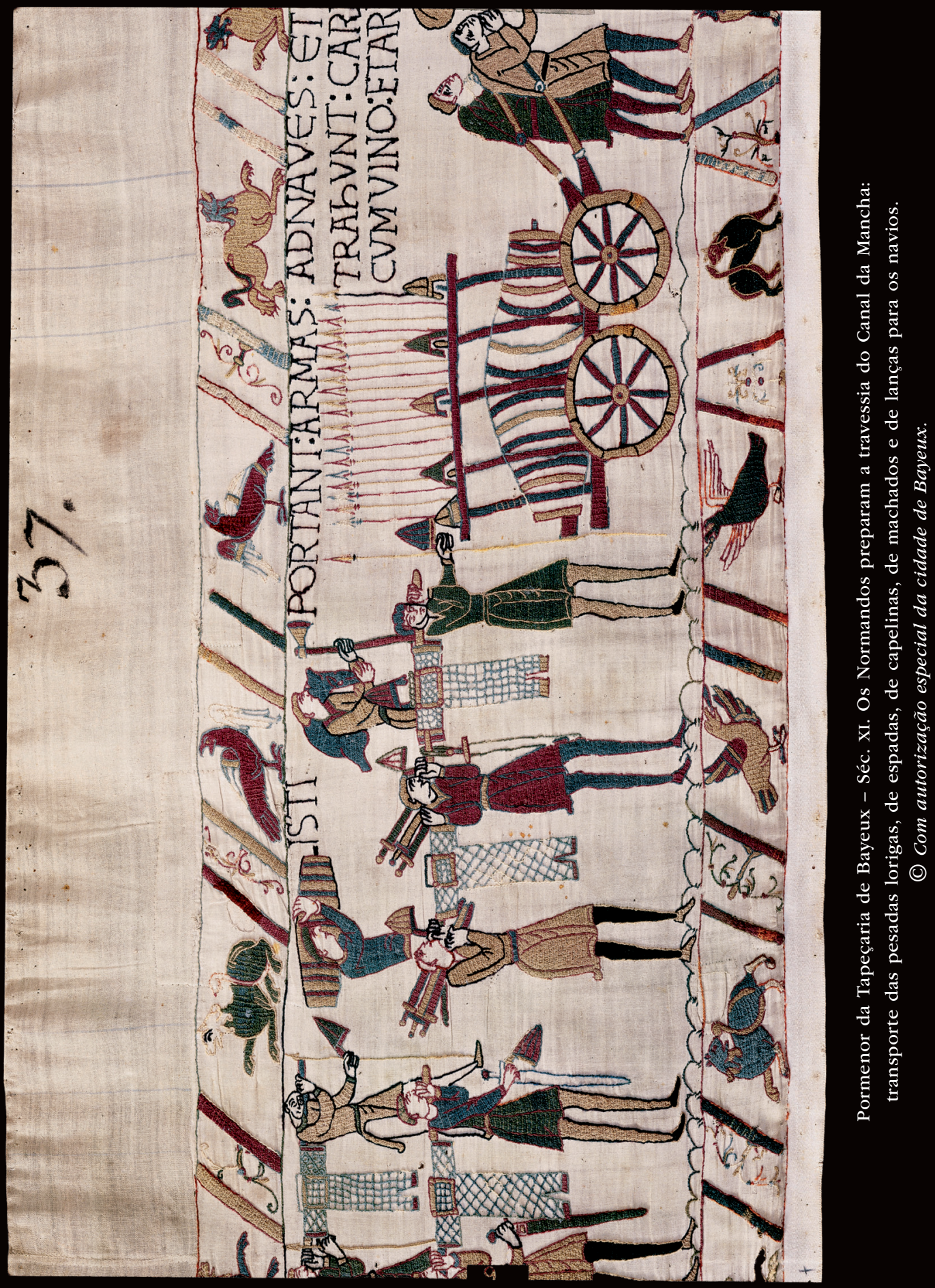


Não sabemos quantos navios mobilizou Guilherme. O monge de Jumièges fala em 3000, o que é um exagero, Poitiers diz que eram 1000 (mais do que os da frota de Agamémnon!), enquanto Wace, no Roman de Rou (note-se que Rou diz respeito a Rolf, o primeiro líder viking da Normandia), dirá que foram 696. Provavelmente, será este último autor, que escreveu no séc. XII, o mais próximo da verdade, embora muitos investigadores modernos admitam que a frota normanda seria um pouco mais modesta, entre os 450 e os 600 navios. Dado o tamanho diferenciado destas embarcações, pormenor que pode ser documentado pela simples observação da Tapeçaria de Bayeux (onde também se percebe que o desenho dos navios normandos se mantinha razoavelmente fiel à sua herança viking), é impossível calcular o número de homens mobilizados pelo duque. Os 50000 adiantados por Guilherme de Poitiers estão fora de questão, variando as estimativas modernas entre os 5000 e os 10000 homens, incluindo os não combatentes (artesãos, pessoal de abastecimento e outros), acompanhados por perto de 2000 cavalos com os respetivos palafreneiros. Guilherme recrutou o grosso dos seus homens na Normandia, depois de ter promovido reuniões individuais com muitos dos barões e vassalos mais destacados, de modo a convencê-los a participar numa operação que ia muito para além das obrigações vassálicas tradicionais. O prestígio militar do duque, a fama da sua generosidade e a riqueza do reino de Inglaterra atraíram muitos homens, não só da Normandia mas também da Flandres, da Bretanha, do Maine, da Île-de-France e de outras regiões vizinhas do ducado, e mesmo da Aquitânia (no sudoeste da Gália). Entre eles, muitos mercenários, uma vez que, como mostrou Marjorie Chibnall, na Normandia anterior a 1066, as forças não feudais (ou pré-feudais) eram bastante importantes, o que fazia com que os exércitos tivessem uma componente forte de guerreiros da casa ducal e de mesnadas pessoais dos barões mais poderosos (condes, viscondes e outros), para além de contingentes não despiciendos de guerreiros pagos a soldo, campanha a campanha. A conquista seria difícil, mas parecia viável (o caos político em que a Inglaterra mostrara tendência para mergulhar ciclicamente nas últimas décadas também parecia facilitar as operações), e tornar-se-ia, decerto, muito compensadora. 
Também se tem discutido se os Normandos terão construído, em 1066, a maioria dos navios em que atravessaram o Canal da Mancha. Como demonstrou Carroll Gillmor, isso teria sido impossível. Guilherme deve ter obtido navios contratando mercenários navais na Flandres e fretando embarcações aqui e noutros principados vizinhos. Pode também ter desenvolvido uma pequena marinha normanda já existente e, como último recurso, mandado construir alguns barcos novos, como Wace e Baudry de Bourgueil também referem.

Sabemos que Guilherme, em inícios ou meados de agosto de 1066, concentrou a sua frota em Dives e nos portos vizinhos (ao longo do rio Sena havia então seis portos disponíveis: Le Dans, Elbeuf, Le Goulet, Saint-Aubin-sur-Quillebeuf, Vieux Port e Rouen). No entanto, o vento sul, que era indispensável para a travessia, tardava a chegar. Como explicam Christine e Gerald Grainge, o tempo esteve durante várias semanas dominado por uma sucessão de baixos atlânticos, que trouxe chuva e ventos de oeste. Na segunda semana de setembro, o duque deve ter começado a desesperar - fazia-se cada vez mais tarde para iniciar a campanha, o verão estava mesmo no fim e os homens impacientavam-se, sendo cada vez mais difíceis de controlar, apesar das imposições de disciplina a que, como diz Guilherme de Poitiers, o duque os sujeitava: "as searas esperavam intactas pela foice do agricultor (...). Um homem simples e desarmado passeava a cavalo por onde queria, cantarolando, sem receio de avistar os esquadrões de cavaleiros" (Parte II, n. $\left.{ }^{\circ} 2\right)^{1}$. Em síntese, um tal atraso ameaçava pôr todo o projeto em causa!

Assim, possivelmente a 12 ou a 13 de setembro, receando que Haroldo II reforçasse cada vez mais a sua posição política em Inglaterra, Guilherme arriscou fazer a travessia, apesar do contexto meteorológico desfavorável.

\footnotetext{
${ }^{1}$ A tradução portuguesa das citações que aqui fazemos do relato de Guilherme de Poitiers é da autoria de José Eduardo Braga. Utilizámos como fonte a versão latina publicada por Duchesne, em 1619 (cf. The Gesta Guillelmi of William of Poitiers", edited and translated by R. H. C. Davis and Marjorie Chibnall, Oxford, Clarendon Press, 2006; ed. orig.: 1998). As traduções das outras fontes são da nossa autoria, mas neste caso foram preparadas a partir das respetivas edições inglesas, utilizando para o efeito a antologia de Stephen Morillo (The Battle of Hastings. Sources and Interpretations, Woodbridge, The Boydell Press, 1996). No caso da Crónica Anglo-Saxónica, as citações serão, regra geral, feitas a partir da versão D desta fonte.
} 
O plano seria navegar diretamente de Dives para Inglaterra, numa distância de 90 a 95 milhas marítimas (isto é, 167 a 177 km). Com vento médio, a operação exigiria entre doze e dezasseis horas de navegação, a uma velocidade de seis a oito nós. Provavelmente, o duque pretenderia viajar durante a noite, de modo a chegar a Inglaterra já com a luz do dia, para evitar os riscos de um desembarque noturno. Em Dives, o efeito da maré seria mínimo no momento da partida, mas é provável que, ainda assim, Guilherme quisesse zarpar com a maré alta do início ou do fim da tarde.

A operação correu muito mal. Os ventos não permitiram cumprir o plano e o duque foi obrigado a procurar abrigo no único porto disponível: o do estuário do rio Somme, em Saint-Valéry. O trajeto fora relativamente curto mas desastroso, com uma tempestade violenta de oeste a fazer alguns navios naufragar e com muitos homens a morrerem afogados, como nos diz Guilherme de Poitiers. Este cronista dá ainda conta dos cuidados do duque em abafar as perdas, sepultando os homens em segredo, de modo a não minar ainda mais o moral das tropas...

Seguiu-se uma nova e longa espera, agora em Saint-Valéry, um porto de recurso no litoral sotavento e, por isso, cheio de perigos. O tempo continuou desfavorável por mais cerca de duas semanas, até 27 ou 28 de setembro. Só então, porventura acedendo às rezas dos guerreiros - que olhavam constantemente para o cata-vento da igreja a ver se o vento mudava e que chegaram a trazer para a rua as relíquias de Saint-Valéry -, é que um sistema de altas pressões trouxe o desejado vento sul, acompanhado de céu limpo e de um sol quente e agasalhador. Guilherme respirou de alívio: São Pedro salvara a expedição. O duque e os seus homens precipitaram-se para os navios e fizeram-se ao mar.

A 27 ou 28 de setembro, em Saint-Valéry, a maré alta terá ocorrido muito perto das $15 \mathrm{~h} 15$ e o Sol ter-se-á posto cerca das 17h30. Quanto à Lua, com seis dias, estima-se que se tivesse recolhido perto das $22 \mathrm{~h}$ (ou um pouco antes). No dia seguinte, o Sol nasceria poucos minutos depois das $6 \mathrm{~h}$. Com estas coordenadas e com um vento e demais condições meteorológicas favoráveis, Guilherme deve ter optado por embarcar com a maré da tarde (como Saint-Valéry é um porto seco, ao contrário de Dives, a única hipótese era navegar com a maré), com o fito de alcançar as praias de Inglaterra pouco depois do nascer do sol do dia seguinte. 


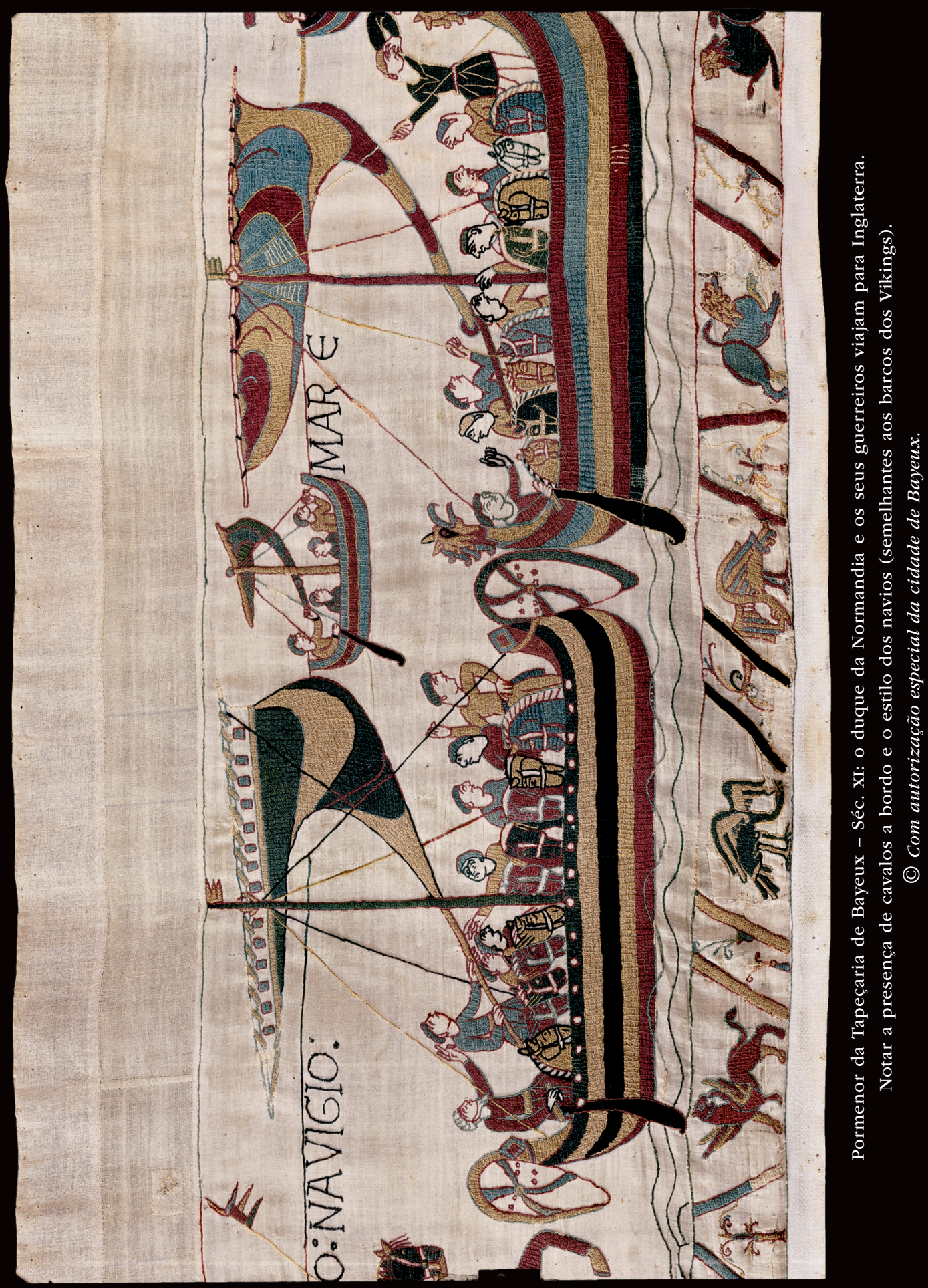


Tanto Guilherme de Poitiers como o poema Carmen referem que a frota normanda lançou âncora assim que alcançou águas profundas. Poderá parecer um pouco paradoxal interromper a viagem pouco depois do seu começo, mas tanto uma fonte como outra adiantam explicações verosímeis para o facto. O Carmen (curiosamente, a fonte que melhor percebeu o drama da viagem e que melhor descreve o quadro meteorológico das semanas anteriores e suas implicações) diz que isso visou possibilitar o agrupamento em formação ordenada das centenas de navios que compunham a frota, uma operação impossível de concretizar logo à saída do estuário do Somme. Pelo seu lado, Poitiers explica que o duque receava atingir o litoral de Inglaterra antes do nascer do sol, pelo que mandou um arauto proclamar uma ordem segundo a qual todo o navio, assim que alcançasse o mar alto, deveria ancorar durante um curto período noturno, não longe do navio de Guilherme, até que visse uma lanterna acesa no seu mastro principal e ouvisse o soar da trombeta anunciando o momento da largada. Segundo os Grainge, que aliam um estudo cuidadoso das fontes à sua experiência pessoal de marinheiros, a partida da frota da baía do Somme deve ter ocorrido por volta das $21 \mathrm{~h} 10$, tendo a travessia demorado cerca de 11 horas.

Assim, o navio de Guilherme (o Mora, oferecido pela esposa Matilde e enfeitado com a bandeira papal), que de lanterna no mastro encabeçava o comboio naval e que era um pouco mais comprido e mais rápido do que todos os outros, deve ter alcançado a praia de Pevensey pelas 8h10 do dia seguinte (28 ou 29 de setembro de 1066). Quando chegou, o duque olhou para trás e percebeu que estava sozinho. Um remador foi mandado subir ao cimo do mastro e noticiou que, para sul, não se avistava senão mar e céu... O Mora, ostentando uma cabeça de animal na proa (à boa maneira viking) e, na popa, um rapaz com uma bandeira-lança a apontar para Inglaterra e a soprar num corno, lançou âncora. Apesar da ansiedade, o duque manteve o ânimo e optou por tomar um excelente pequeno-almoço a bordo, regado por um vinho saboroso "como se estivesse no seu salão, em casa” (G. de Poitiers). Guilherme estava seguro de que os restantes navios não tardariam a chegar, e a travessia marítima e a visão da terra que queria conquistar abriram-lhe certamente o apetite. 
Pouco depois, começaram a chegar a Pevensey todos os outros navios, exceto dois, que, por rumarem demasiado a leste, acabaram por aportar em Romney, onde parece que os passageiros foram massacrados pela população local. A primeira parte do plano de conquista do reino anglo-saxónico tinha sido cumprida. Guilherme deve ter sentido algum alívio, pois a travessia marítima comportava sempre os seus riscos: o vento podia mudar a qualquer momento e complicar a viagem, ainda que curta; o mar podia encrespar; e, se o vento amainasse demasiado, também não teria sido bom, pois obrigaria os navios a navegar à força de remos, o que teria deixado os homens exaustos. Por outro lado, como o número de navios era elevado, caso navegassem demasiado próximos uns dos outros, para não perderem o contacto, haveria o risco de colisão e de naufrágio.

Nada disso, porém, acontecera e, na praia de Pevensey, também não surgiu qualquer obstáculo ao desembarque dos Normandos. Haroldo II não conteve a travessia dos inimigos e dificilmente poderia ter feito outra coisa: a única forma de o rei inglês suster o comboio naval do duque teria sido ficar à espera dele ao largo da costa normanda (tal como viria a suceder nos inícios do séc. XIX, durante os bloqueios das Guerras Napoleónicas), mas este género de operação teria sido impossível de concretizar com navios do séc. XI, muito vulneráveis aos efeitos do mau tempo. Assim, a menos que a frota invasora desembarcasse junto a uma concentração de navios anglo-saxónicos, não teria sido possível desdobrar a esquadra inglesa de forma suficientemente rápida para possibilitar um combate naval. Nem isso estaria nos planos dos dois comandantes, uma vez que os navios coevos serviam sobretudo para o transporte de tropas e para viabilizar fugas rápidas em caso de insucesso num combate terrestre. Deste modo, Guilherme deve ter considerado remotas as possibilidades de ser intercetado durante a viagem marítima e, por isso, viajou aparentemente sem escolta.

Muitos autores (como Carroll Gillmor ou John Gillingham) têm defendido que o atraso na chegada da frota normanda a Inglaterra foi o resultado, não tanto do mau tempo que se fez sentir até finais de setembro, mas sobretudo de uma opção deliberada do duque. Segundo esta tese, Guilherme sabia que, no final da primavera, Haroldo tinha reunido um grande exército e uma poderosa frota no sul de Inglaterra e que aguardava ali o ataque do 
seu rival. Por isso, o duque terá esperado até o rei inglês ser obrigado a desmobilizar as suas tropas por falta de provisões e por se ter esgotado o tempo a que essas gentes estavam obrigadas a servir o rei. É verdade que Haroldo II, avisado dos preparativos de Guilherme na Normandia e atacado, logo em finais de abril ou em inícios de maio, pelo seu irmão Tostig, mobilizou uma hoste que a Crónica Anglo-Saxónica considera como a maior frota e o maior exército jamais reunidos por um monarca inglês. E também é certo que, por volta do dia 8 de setembro, foi forçado a desmobilizar um tal exército. É tentador relacionar este último facto com a diligência (falhada) de Guilherme de zarpar de Dives a 12 ou 13 de setembro, em direção a Inglaterra. No entanto, parece excessivo admitir que o duque ficou os meses de agosto e de setembro quase completos na costa normanda - consumindo alimentos e forragens, pagando soldos, sentindo cada vez mais dificuldade em manter os seus homens disciplinados e moralizados, vendo a 'estação da guerra' passar e deixando a Haroldo II a possibilidade de multiplicar acordos e alianças de reforço da sua autoridade e influência - apenas com receio de desembarcar em Inglaterra em circunstâncias desfavoráveis. Somos levados a crer que foi, de facto, o mau tempo que esteve na origem do enorme atraso na travessia normanda. Mais uns dias e a expedição teria abortado, para desespero do duque e frustração dos seus bravos.

Quanto à escolha de Pevensey como lugar de desembarque, pensa-se que o duque terá querido evitar Dover por ser uma opção demasiado óbvia: como já dissemos, esta era a principal porta da entrada sul em Inglaterra e Guilherme até já teria manifestado a Haroldo o seu grande interesse por ela, durante a 'negociação' de 1064. Portanto, podia muito bem ser que o rei inglês se tivesse prevenido reforçando fortemente a guarnição local, e o chefe normando não quis ser apanhado na armadilha. Além disso, Pevensey era, em si mesmo, um lugar interessante, pois o acesso interior, a partir do norte, era bastante estreito e difícil e a praia oferecia boas condições para abrigar os navios. Pevensey tinha, além disso, uma fortificação (um forte saxónico de formato oval irregular, colocado num ponto alto, acima da zona pantanosa envolvente), que Guilherme tratou imediatamente de reforçar mediante uma pequena defesa temporária dentro das muralhas, de modo a colocar as suas tropas a salvo em caso de necessidade. 


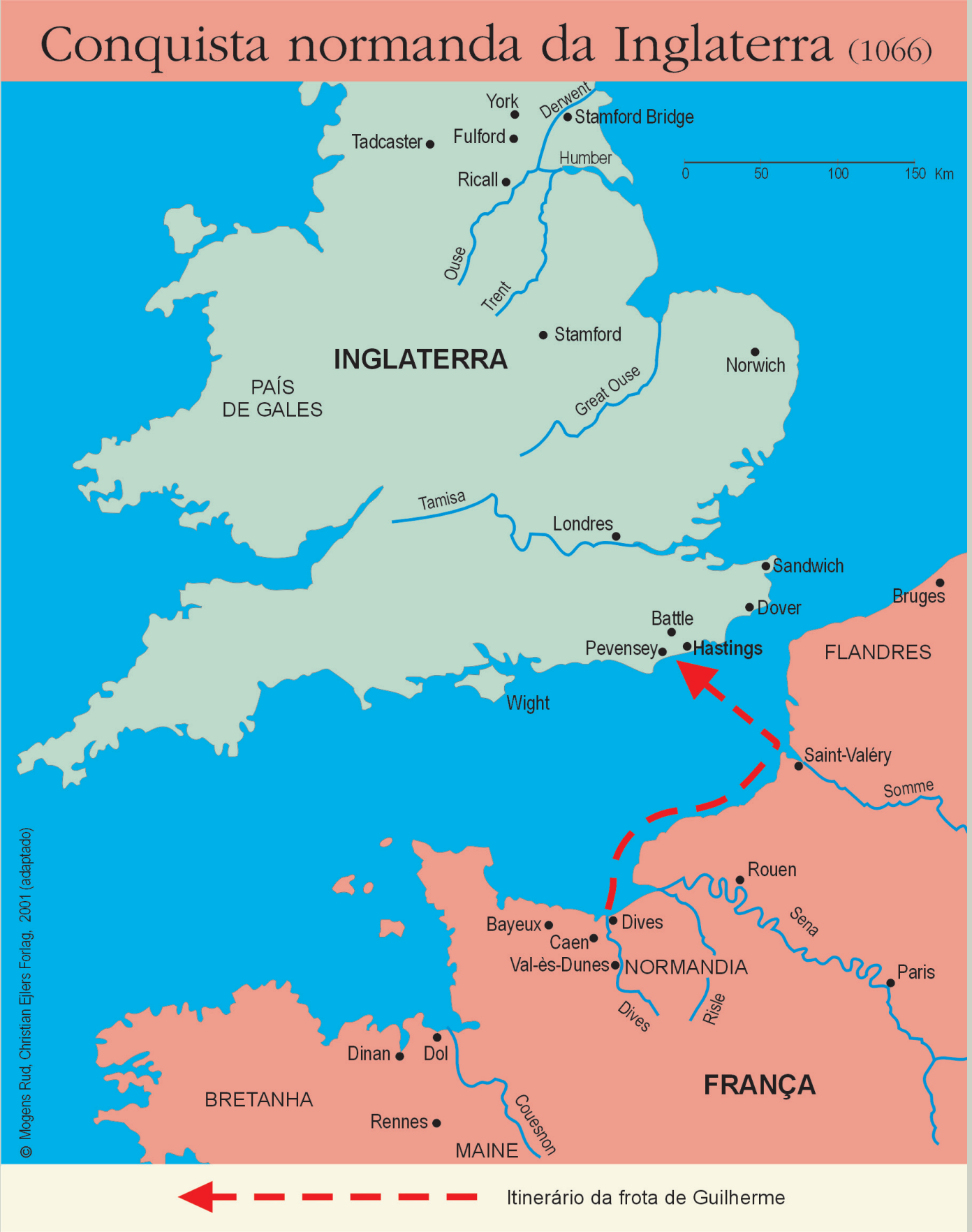


Desembarcados os homens, os cavalos e todo o vasto trem de apoio, o duque começou a explorar a região circundante e não demorou muito a transferir o seu exército para Hastings, uma outra povoação costeira situada escassos quilómetros a leste de Pevensey e onde mandou erguer outro castelo de mota. A Tapeçaria de Bayeux apresenta alguns cavaleiros normandos equipados com lorigas em missões de reconhecimento, e Guilherme de Poitiers explica que o próprio duque participou nestas expedições, acompanhado por um grupo de 25 cavaleiros, entre os quais os seus mais íntimos e dedicados, como o robusto Guilherme Fitz Osbern. A tapeçaria dá também conta dos resultados das primeiras operações de abastecimento, mostrando os combatentes normandos a trazerem ovelhas e porcos para o arraial e a procederem a diversos cozinhados na praia, incluindo autênticos barbecues: veem-se marmitas de sopa ao lume, espetadas de carne a assar, pães quentes (ou bolos) a serem retirados de um forno e, depois, as iguarias a serem degustadas em mesas improvisadas com escudos invertidos apoiados em cavaletes de madeira; à volta dessas mesas, senta-se o estado-maior normando, incluindo Guilherme e o seu meio-irmão, o bispo Odão de Bayeux - que, por ser sexta-feira, tem à sua frente um grande peixe assado...

No entanto, não se tratava apenas de recolher alimentos, mas também de devastar a região circundante, que era, aliás, de há muito, terra dos Godwin... Isto denuncia claramente a estratégia normanda: atrair Haroldo II ao sul e dar-lhe razões para travar uma batalha campal! Veremos agora se esta paixão de Guilherme (então com 38 ou 39 anos) era correspondida pelo seu rival, um pouco mais velho (Haroldo tinha na altura 44 anos) e já razoavelmente calejado e instruído nos segredos da arte militar.

\section{O ‘verão quente' de 1066 - Fulford Gate e Stamford Bridge}

Uma das principais decisões tomadas por Haroldo II após a sua coroação, em inícios de 1066, consistiu em casar-se com uma neta de Leofric da Mércia, o antigo valido de Eduardo. Ou seja, o rei inglês, que já tivera vários filhos da sua amante Edite "colo de cisne", contraiu matrimónio com 
outra Edite, a irmã dos condes Edwin da Mércia e Morcar da Nortúmbria, de quem viria a ter ainda dois filhos gémeos, Ulf e Haroldo (nascidos, talvez, já depois da batalha de Hastings). Foi uma decisão inteligente, que uniu os dois maiores poderes do reino e que reforçou a posição política do recém-empossado Haroldo II. Os meses seguintes comprovarão o acerto desta estratégia, quando o norte for invadido por forças estrangeiras.

Os maus presságios anunciados em finais de abril pelo cometa Halley não demoraram a confirmar-se. Em inícios de maio, Tostig Godwinson, o irmão desavindo de Haroldo II, viajou da Flandres para Inglaterra e desembarcou na Ilha de Wight, com 60 navios, dinheiro e provisões. Segundo o cronista de Worcester, Tostig exigiu o pagamento de um tributo aos habitantes e recebeu ainda o apoio do seu antigo lugar-tenente, Copsi, que veio das Ilhas Orkney, então sob dominação norueguesa, com mais 17 navios. Depois, Tostig e Copsi entregaram-se à pilhagem da costa sul de Inglaterra, até Sandwich (ligeiramente a norte de Dover). Ao saber disto, o monarca inglês reuniu uma grande frota e um enorme exército terrestre, que incluía uma componente de cavalaria, que teria o cuidado de conservar consigo até à batalha de Hastings.

Nesta época, os exércitos reais ingleses eram compostos por três núcleos principais: os housecarls, as tropas do fyrd e os butsecarls. Os housecarls eram as tropas de elite, muito bem treinadas e equipadas; devem ter sido introduzidas por Cnut "o Grande" (1016-1035), pois eram próprias da tradição militar escandinava. Hoje, pensa-se que não seriam exatamente mercenários permanentes, pagos pelo tesouro do rei, embora em 1066 ainda recebessem salários com base no danegeld consolidado por Cnut logo em 1016. Os bousecarls eram proprietários fundiários, que estavam obrigados a defender as suas propriedades em caso de invasão ou de insurreição, mas que podiam também servir como guardas pessoais do rei, dos condes ou de outros grandes senhores, tanto em tempo de guerra como em tempo de paz, ou até em tarefas burocráticas, como a cobrança de impostos; militares reputados, os housecarls formavam uma law-bound guild, ou seja, um tipo de instância de controlo do witenagemot ou conselho do rei. Como notou Kelly DeVries, coube a esta elite assegurar a proteção da viúva Ema da Normandia durante a usurpação de Haroldo I (1037-1040), punir os cidadãos de Winchester 
durante a revolta destes contra o rei Hartacnut (1040-1042), acompanhar o exílio (e o regresso) dos Godwin, em 1051-1052, ou lidar com a revolta dos Nortumbrianos contra Tostig Godwinson, em 1065. O seu primeiro dever era lutar como soldados, e deram bons exemplos disso no País de Gales, durante as campanhas de 1063 e também durante os acontecimentos do 'verão quente' de 1066 em Inglaterra. Nesta data, já nem todos os housecarls eram dinamarqueses: como explica a Crónica Anglo-Saxónica, alguns eram ingleses, atraídos pelo estatuto e pelo salário da função, aos quais se chamava liths. É provável que na batalha de Stamford Bridge, cerca de duas semanas e meia antes de Hastings, tenha havido uns 300 bousecarls a combater ao lado de Haroldo II.

Kelly DeVries pensa que os housecarls seriam, possivelmente, a melhor força militar europeia. Combatiam com o machado de duas mãos e cabo longo (com o qual conseguiam abater um homem e o seu cavalo de um só golpe), ou com a espada (dizendo-se que, com ela, eram capazes de rachar um adversário ao meio, de alto a baixo, sem se notar o corte!). Note-se que a espada longa (com cerca de $76 \mathrm{~cm}$ de lâmina) foi também consolidada pelos Vikings em Inglaterra; era uma arma de duplo fio (isto é, com dois gumes afiados), que se utilizava sobretudo para cortar de través, e não tanto para estocar; era extraordinariamente estimada pelos armeiros, que por vezes inscreviam o seu nome nas lâminas que fabricavam. Subsidiariamente, os housecarls utilizavam maças e dardos ou lanças; a Tapeçaria de Bayeux dá uma imagem enganadora do equipamento defensivo destes homens ao ponto de eles se confundirem com os seus adversários normandos. Como lembra Mogens Rud, com base nas investigações minuciosas de Charles H. Lemmon, os housecarls vestiam casacas de couro sem mangas, sobre as quais eram cosidos anéis de ferro, calças com correias na frente e sandálias; tinham geralmente o cabelo comprido e os seus capacetes, munidos de nasal, dispunham de longas peças de couro que lhes caíam sobre os ombros; geralmente, usavam os longos escudos em forma de papagaio pendurados a tiracolo nas costas, o que lhes assegurava uma boa proteção a ataques da retaguarda e lhes deixava as duas mãos livres para manejar o temível machado de guerra de cabo comprido; com frequência, no campo de batalha, os bousecarls eram emparelhados com lanceiros, formando uma dupla temível, tanto na ofensiva como na defensiva. Nesta variante, 
cada housecarl beneficiava da proteção conferida pelo escudo do lanceiro posicionado à sua direita, uma vez que (como já sabemos desde a análise das guerras entre os hoplitas gregos) o combate com arma branca desloca o centro de gravidade da luta para o flanco direito.

Quanto ao fyrd, era o nome dado ao recrutamento geral da milícia, ou seja, ao 'povo em armas'. Em teoria, a mobilização do fyrd podia, em casos de urgência, implicar o recrutamento de todos os homens livres fisicamente aptos; contudo, geralmente apenas se mobilizava uma parte selecionada da população, recorrendo-se de preferência às mesmas pessoas, de maneira a assegurar alguma experiência e capacidade bélicas. Os fyrdmen eram camponeses e comerciantes, que tinham a obrigação de servir por dois meses em tempo de guerra, desde que auferissem rendimentos superiores a cinco bides de terra ( 1 bide $=24$ a 48 hectares, consoante a época e a região); em tempo de paz, colaboravam na construção e manutenção de fortificações (na Inglaterra anterior a 1066, tratava-se sobretudo de muralhas urbanas, pois quase não havia castelos) e na reparação de pontes. É provável que o recrutamento do fyrd estivesse organizado por condados (shires), pelo que, não raro, os próprios condes mobilizavam os respetivos fyrdmen para com eles defenderem as fronteiras do seu condado (um modelo de autêntico 'feudalismo nascente'). A posse das referidas cinco bides de terra qualificava os proprietários como thegns e sujeitava-os à prestação do serviço militar. Este modelo, que à boa maneira feudal enfatizava a relação entre a posse de terra (bookland) e a obrigação de prestar um serviço militar nas guerras do rei (designadamente para defesa desse bem), vigorou durante muito tempo, embora se possa detetar uma evolução no sentido de um pagamento pecuniário (em shillings), em substituição da prestação de um serviço pessoal. Como armamento preferencial, os fyrdmen utilizavam sobretudo armas de caça (como a lança ou o arco), escudos e elmos, sendo rara a utilização de boas defesas de corpo em malha metálica (cf. a Tapeçaria de Bayeux, onde nenhum fyrdman aparece representado com uma defesa robusta de tronco, ou mesmo de cabeça). Tanto em Fulford Gate como em Stamford Bridge e em Hastings, as três grandes batalhas deste louco final de verão ou início de outono de 1066 em Inglaterra, as tropas do fyrd devem ter composto o grosso das tropas inglesas. 
Por fim, os butsecarls. Trata-se, neste caso, de marinheiros capazes de combater em terra e no mar. Podem ter sido pagos como mercenários, mas só dispomos de um exemplo seguro para os acontecimentos de 1066: o pequeno grupo de butsecarls que se juntou a Tostig na costa sul, em julho-agosto, alguns dos quais permaneceram com ele até à batalha de Stamford Bridge, em finais de setembro.

Foi com um exército de housecarls e de fyrdmen e com a mobilização de uma boa frota (o chamado scipfyrd, ou seja, o fyrd naval) que Haroldo II respondeu à agressão do seu irmão Tostig. Segundo João de Worcester, o rei preparou-se para ir pessoalmente a Sandwich, mas Tostig recrutou (a bem e à força) moradores nesta localidade costeira e abalou para Lindsey, na margem sul do Humber, onde se entregou ao incêndio de aldeias e a outros crimes. Não se sabe bem qual o objetivo de Tostig, mas porventura pensaria recuperar o seu antigo condado da Nortúmbria. Isto obrigou o conde da Nortúmbria, Morcar, a reagir, no que foi auxiliado pelo seu irmão Edwin, conde da Mércia. Os dois conseguiram expulsar Tostig e obrigaram-no a procurar refúgio na Escócia, junto do seu velho amigo, o rei Malcolm Canmore, que já atacara a Nortúmbria por cinco vezes desde 1054. Segundo a Crónica Anglo-Saxónica, à chegada à Escócia, Tostig já só dispunha de 12 navios.

Entretanto, Haroldo II chegou a Sandwich e aguardou aí a chegada da sua frota, com a qual partiu depois para a Ilha de Wight. Foi aqui que o rei inglês teve a confirmação daquilo de que há muito desconfiava: o duque Guilherme II da Normandia preparava uma invasão em força da Inglaterra, onde iria reclamar o título de rei que alegadamente lhe tinha sido prometido por Eduardo "o Confessor" e confirmado pelo próprio Haroldo.

Ao saber disto, o rei inglês decidiu vigiar, durante todo o verão, a chegada dos Normandos e, em conformidade, distribuiu as suas forças terrestres (sobretudo as de infantaria) por diversos pontos estratégicos situados ao longo do litoral. Porém - segundo a narrativa do cronista de Worcester, que é nesta matéria a nossa fonte mais pormenorizada -, Guilherme tardava a chegar e, por ocasião da festa da Natividade de Santa Maria (ou seja, a 8 de setembro), Haroldo foi obrigado a desmobilizar as suas tropas navais e terrestres por falta de provisões (e, acrescentamos nós, porque provavelmente já tinha expirado o prazo de serviço militar obrigatório da maioria desses contingentes). 
Foi uma situação bastante infeliz para Haroldo II, pois justamente por essa altura o rei da Noruega, Harald Hardrada (que, em 1062, vencera Sven II Estridsen da Dinamarca na batalha naval de Nissa), e Tostig Godwinson chegavam a um entendimento para uma invasão conjunta da Inglaterra! O acordo terá sido negociado no fiorde de Oslo e, na sequência dele, Tostig ter-se-á tornado vassalo do rei norueguês (assim o diz a Crónica Anglo-Saxónica) e terá partido para a Flandres, em busca de mais apoios. Hardrada, pelo seu lado, concentrou as suas forças mais a norte, em Bergen, e, em inícios de setembro, navegou para sul, deixando o seu filho Magno II a governar a Noruega; recolheu apoios nas Ilhas Orkney e seguiu depois para Inglaterra, entregando-se a raides pela costa leste, em Cleveland, Scarborough e Holderness. O cronista de Worcester afirma que Hardrada surgiu de surpresa na foz do rio Tyne (em Newcastle, entre York e Edimburgo) com 500 navios, mas a Crónica Anglo-Saxónica fala em 300 barcos, o que parece mais razoável. O certo é que, conforme o combinado previamente, Tostig se juntou ao rei da Noruega com a sua frota e os dois aliados entraram pelo estuário do Humber, subiram depois o rio Ouse, contra a corrente, e desembarcaram em Ricall, já relativamente perto da grande cidade de York.

O alarme soou com toda a veemência e os dois condes irmãos, Morcar e Edwin, mobilizaram um vasto exército nos seus condados (eis um exemplo de recrutamento das forças do fyrd no âmbito dos shires) e decidiram sair ao caminho dos exércitos inimigos antes de eles poderem alcançar York. Foi neste contexto que se deu, a 20 de setembro de 1066, a batalha de Fulford Gate, a norte do rio Ouse e escassos três quilómetros a sul de York. Não se sabe exatamente o volume de efetivos envolvidos neste combate, mas Kelly DeVries (1999), que estudou em pormenor esta invasão norueguesa, estima que Hardrada e Tostig pudessem então contar com 15000 a 18000 homens. A batalha foi indiscutivelmente renhida (o que confirma a versão de João de Worcester, segundo a qual o exército dos condes era bastante numeroso), mas os Noruegueses e os seus aliados acabaram por vencer. De um lado e de outro, parece ter havido bastantes baixas: segundo o cronista de Worcester, foram ainda mais os Ingleses que se afogaram no rio Ouse, durante a fuga, do que durante o combate propriamente dito um facto que não constitui novidade nas batalhas medievais, em que as chacinas geralmente se consumavam na fase da perseguição. 
Na sequência da batalha de Fulford Gate, Edwin e Morcar foram forçados a fazer as pazes com Hardrada, que de imediato se dirigiu para York. Aqui, os cidadãos depressa optaram por negociar a rendição: foi acordada a troca de 150 reféns que, segundo Mogens Rud, ficaram de ser entregues pelos Ingleses em Stamford Bridge (um lugar aprazível, um pouco mais a leste, nas margens do rio Derwent) passados alguns dias, já que se tratava de reféns de todo o condado e era preciso tempo para os reunir. De acordo com o mesmo autor, o trato de paz entre os iorquinos e os Noruegueses e seus aliados pode ter previsto igualmente a participação dos nortistas numa marcha para sul, que visaria entregar o trono de Inglaterra a Harald Hardrada.

Não sabemos quando é que Haroldo II teve notícia da invasão da Nortúmbria pelos Noruegueses. Não é provável que tivesse tido conhecimento prévio dos planos de Hardrada, só pelo facto de andar a vigiar os movimentos de Tostig - isso implicaria valorizar excessivamente as redes de comunicação e de espionagem coevas, como bem notou Kelly DeVries. Segundo Philip Morgan admitiu muito recentemente, Haroldo II pode ter sido alertado por faróis costeiros, mas mesmo isso não deverá ter sucedido antes do dia 15 ou 16 de setembro, o mais cedo que os Noruegueses podem ter desembarcado em Ricall. Alarmado, o rei inglês foi obrigado a reunir novamente de urgência o seu exército (que tinha desmobilizado na semana anterior...) e a fazer uma opção difícil: marchar para norte e enfrentar Hardrada e Tostig, embora deixando a costa sul de Inglaterra exposta a um ataque normando. O mais importante, para Haroldo, era evitar compromissos entre Hardrada e os iorquinos, de maneira a não vir a ter de defrontar em breve uma força anglo-escandinava, o que seria terrível.

Não se conhecem pormenores sobre as operações de Haroldo, mas este monarca deve ter feito um esforço desesperado para juntar de novo tropas volumosas e qualificadas. Provavelmente, privilegiou a chamada de tropas de elite (os bousecarls) e de tropas montadas do fyrd, parte das quais deve ter guardado perto de si desde o meio do verão, como já dissemos. Pensando decerto que seria melhor enfrentar um inimigo de cada vez, e que ficaria mais liberto para lidar com Guilherme (quando este chegasse) depois de derrotar Hardrada e Tostig, Haroldo II organizou uma verdadeira marcha forçada, de dia e de noite, entre Londres e York. Pelo caminho, foi 
provavelmente engrossando a sua hoste com tropas locais, de tal maneira que chegou ao norte já com um exército de muitos milhares de homens bem equipados (João de Worcester). É impressionante a rapidez com que o monarca organizou tudo isto, pois entre Londres e Tadcaster (que alcançou na noite de domingo, dia 24 de setembro) distam pouco menos de $300 \mathrm{~km}$ !

Em Tadcaster (uns $17 \mathrm{~km}$ a sudoeste de York), Haroldo informou-se do que tinha acontecido nos dias anteriores e ficou a saber da batalha de Fulford Gate. Apesar de todo o seu esforço nos últimos nove dias, o rei chegara tarde demais... Porém, nem tudo estava perdido: de imediato, tratou de engrossar um pouco a sua hoste com os sobreviventes do combate de dia 20 (incluindo, talvez, o conde Morcar, que tinha escapado e que não acompanhara o irmão Edwin a York) e, eventualmente, também com os butsecarls que se tinham refugiado no rio Wharfe, ao pé de Tadcaster. Obviamente, Haroldo II tomou conhecimento da presença da frota norueguesa em Ricall (cerca de $11 \mathrm{~km}$ a sudeste de Tadcaster), mas não se arriscou a atacá-la, até porque a maioria do exército de Hardrada não estava lá e o rei inglês queria mesmo era aplicar um golpe decisivo nos invasores. Assim, optou por, logo na madrugada do dia seguinte (25 de setembro, uma segunda-feira), avançar para York (onde os espantados cidadãos não quiseram renegar o acordo que tinham feito com Harald Hardrada e com Tostig) e, depois, por ir no encalço destes dois adversários, de modo a apanhá-los completamente de surpresa. O plano do rei inglês não podia ter tido maior sucesso.

Na verdade, o exército norueguês não tivera o cuidado de colocar batedores nas proximidades de York, decerto porque considerava impossível o rei inglês aparecer tão rapidamente na sua peugada, ou porque o cuidava demasiado atento à costa sul, por causa da chegada da frota normanda. Assim, Hardrada e Tostig haviam decidido deixar algumas tropas a guardar a frota em Ricall, sob o comando de Olavo (filho do próprio Hardrada) e de dois condes das Ilhas Orkney (um deles chamado Paulo), e avançaram para Stamford Bridge. Porque o tempo estava quente e muito soalheiro, e porque a jornada era de relativa tranquilidade, pensavam eles, os dois aliados cometeram um erro fatal: deixaram ficar nos navios as suas defesas de corpo (as pesadas lorigas) e marcharam apenas com as armas ofensivas, os escudos e os elmos! O facto não é referido por nenhuma fonte anglo-saxónica (ou 
anglo-normanda) coeva, mas Kelly DeVries chama a nossa atenção para ele, pois consta de todas as Sagas dos reis noruegueses, escritas nos sécs. XII ou XIII, em especial das mais minuciosas (a Fagrskinna, a Morkinskinna e a Heimskringla, esta última de Snorri Sturluson, redigida em inícios do séc. XIII); o episódio surge também na Historia de Saxo Gramático, um historiador medieval dinamarquês, que viveu entre c. 1150 e 1220 e que foi autor da primeira história completa da Dinamarca (a Gesta Danorum).

Não se conhece bem o local onde os Noruegueses dormiram na noite de 24 para 25 de setembro. Alguns autores admitem que possam ter acampado ainda em Ricall, por uma questão de segurança e para evitarem o transporte de vitualhas entre os navios e Stamford Bridge (a cerca de $30 \mathrm{~km}$ de distância de York); porém, tendo em conta os acontecimentos do dia seguinte, não acreditamos que tal tenha sucedido. Em nossa opinião, no dia 25 o exército norueguês e os seus aliados acordaram já em Stamford Bridge. Estavam implantados numa posição confortável, na margem leste do rio Derwent, num terreno ligeiramente elevado (cerca de 15 ou $16 \mathrm{~m}$ acima do leito do rio) e que é hoje conhecido por "Battle Flats"; o acesso a esta margem do rio, para quem vinha de York, fazia-se por uma estreita ponte de madeira. Não sabemos quantos homens Hardrada e Tostig teriam então consigo, mas, depois de Fulford Gate e com a frota estacionada em Ricall, certamente que os 15000 a 18000 efetivos que há pouco referimos estariam bastante reduzidos; tanto mais que, provavelmente por exigências de abastecimento, uma parte dos homens que seguira para Stamford Bridge fora enviada em operações de forragem no lado poente do rio.

Ora, foram justamente estes forrageadores os primeiros a serem surpreendidos pela chegada do exército inglês, liderado pelo rei Haroldo II; sem tempo para fugir, foram chacinados. Sem se deter mais, a hoste real encaminhou-se para a ponte de madeira que dava acesso à margem leste da linha de água. Nessa altura, segundo o relato da Crónica Anglo-Saxónica (versão C), os soldados de Haroldo depararam com um obstáculo imprevisto: a entrada da ponte estava a ser defendida por um gigante norueguês que, com o seu machado, derrubou rapidamente uns 40 ingleses... Ao que parece, foi muito difícil abater este bravo guerreiro viking (que, a ser verdadeira esta história, estaria acompanhado por um grupo pequeno de camaradas), 
cujo objetivo parece ter sido o de dar tempo ao grosso do exército norueguês para se aperceber da tragédia e se preparar minimamente para o combate. Curiosamente, as Sagas nada dizem sobre este episódio heroico, talvez porque ele impressionou mais os Ingleses. Segundo dirá Guilherme de Malmesbury, o gigante norueguês acabou por ser morto devido ao arremesso de uma lança curta (um dardo) que o trespassou; porém, a Crónica Anglo-Saxónica (neste caso, através de um acrescento do séc. XII à versão C), e também Henrique de Huntingdon, apresentam uma versão diferente: o obstáculo só foi ultrapassado por volta das 3 horas da tarde, depois de tentativas infrutíferas dos arqueiros de Haroldo, quando um soldado inglês se meteu num bote e, através das aberturas da ponte, atingiu o gigante nas "partes privadas" com uma lança!

Entretanto, do lado de lá da ponte, depois de um período de indiferença (pensando que se tratava de forças aliadas), Hardrada e Tostig tinham sido obrigados a reconhecer a gravidade do problema: conta a Fagrskinna que "quanto mais perto os homens chegavam, mais o exército [inglês] crescia, até que, com as suas armas resplandecentes, pareciam como que gelo quebrado" (in K. DeVries, 1999, p. 278). Perante o dilema, Tostig propôs retirarem e regressarem velozmente aos navios, mas Hardrada preferiu enfrentar o opositor e enviou apenas três estafetas nos cavalos mais rápidos que tinha, para mandar vir reforços de Ricall. A seguir, o experiente rei norueguês organizou um dispositivo tático concebido para opor uma feroz resistência aos adversários: uma formação alongada, mas com as alas de tal maneira curvadas que se tocavam; daqui acabou por resultar um círculo largo e espesso, com os escudos a sobreporem-se nos topos. Hardrada, acompanhado do seu séquito e do seu estandarte (o célebre "Devastador de terras", um símbolo para os seus homens), colocou-se no interior do círculo, o mesmo tendo feito Tostig, que transportava um segundo estandarte. Segundo a Heimskringla de Snorri Sturluson, as sua ordens foram muito claras: os homens da linha da frente da parede de escudos deviam espetar as hastes das suas lanças no chão e dirigir as pontas afiadas aos peitos dos cavaleiros adversários, caso estes carregassem; quanto aos homens que estavam mais atrás, deveriam apontar as pontas das lanças contra os peitos dos cavalos inimigos. Hardrada recorreu a este dispositivo também porque sabia que a 
cavalaria "estava habituada a carregar para diante e era rápida a cavalgar para trás" (Heimskringla, in K. DeVries, 1999, p. 283). Ele e Tostig, dentro do círculo, avançariam para reforçar as zonas da parede de escudos que estivessem a ser atacadas, e os seus arqueiros (não sabemos quantos seriam, mas provavelmente não eram muitos) ficariam também no interior do círculo e disparariam mísseis sobre os cavalos que se aproximassem, qualquer que fosse a direção em que eles carregassem.

Foi este o cenário que Haroldo e os seus homens encontraram, quando finalmente conseguiram cruzar o rio e alcançar Battle Flats. A demora na travessia da ponte e a robustez da parede de escudos circular prometiam obrigar os Ingleses, se bem que em clara superioridade numérica, a muito esforço e a muitas baixas. A única forma de levar de vencida uma parede de escudos era atacá-la repetidamente, de maneira a enfraquecê-la, a pôr os adversários em debandada, a forçá-los à rendição ou a exterminá-los; no caso de um dispositivo circular, o problema era ainda maior, uma vez que este tipo de formação era especialmente difícil de atacar, pois não tinha flancos para serem envolvidos. Poderia sempre considerar-se a hipótese de uma fuga simulada, mas era preciso que fosse muito convincente para resultar. Fora isso, não restava outra alternativa senão o ataque frontal.

Antes de o ordenar, dizem as Sagas que Haroldo, acompanhado por 20 cavaleiros vestidos de malha metálica, se dirigiu pessoalmente a Tostig, propondo-lhe um bom acordo; este, porém, recusou altivamente a proposta, sobretudo porque ela não contemplava nenhuma vantagem para Hardrada, de quem se tinha tornado vassalo. Quando Tostig inquiriu o seu irmão acerca do que este oferecia ao rei da Noruega, Haroldo terá respondido: sete palmos de terra, ou mais, porque ele é mais alto do que os outros homens...

Trocadas estas palavras, os Ingleses investiram a cavalo sobre os inimigos, executando várias cargas com o maior ímpeto possível; contudo, a parede nórdica resistiu e chegou a embaraçar os assaltantes com uma constante barrage de fogo dos arqueiros posicionados dentro do ćŕrculo defensivo. Snorri Sturluson explica que os cavaleiros ingleses cavalgavam à volta do círculo, carregando de vez em quando e retirando rapidamente.

De súbito, a parede de escudos norueguesa dissolveu-se, porque os soldados nórdicos decidiram passar ao ataque; a manobra fracassou por 
completo. Snorri Sturluson dá a entender que isto pode ter sido uma resposta a uma provocação dos Ingleses para atrair os defensores do círculo, mas as restantes Sagas não dão essa impressão: veem a manobra como um contra-ataque interpretado pelos Noruegueses, em reação a um assalto bastante feroz dos adversários. Hardrada foi particularmente valente neste contra-ataque, lutando sem escudo e sem a sua loriga (a famosa "Ema", que tinha ficado nos navios) e brandindo armas nas duas mãos, com as quais liquidava todos os que lhe surgiam pela frente. Mas, como comenta Kelly DeVries, foi uma manobra infeliz e temerária, irrefletida até, para mais numa altura em que a parede de escudos estava a aguentar bem o assalto. Hardrada deveria ter esperado pelos reforços que tinha mandado chamar; se o tivesse feito, poderia ter vencido. A acreditar em Sturluson, Haroldo II também pode ter suspeitado desses reforços e, por isso, terá insistido em sucessivas cargas sem grande brilho, para conseguir arrancar rapidamente os inimigos da sua posição forte.

De acordo com DeVries, o maior estudioso desta batalha e conhecedor profundo das respetivas fontes, os únicos motivos válidos para o rompimento da parede de escudos norueguesa poderão ter sido: i) tratar-se de um berserkgangr, isto é, de uma fúria incontrolável, típica dos guerreiros nórdicos; ii) ou Hardrada ter acreditado que teria uma chance se aplicasse um golpe de surpresa contra os Ingleses, levando-os a abandonar o campo de batalha. Como quer que tenha sido, a ideia foi fatal: os homens de Haroldo aguentaram e depressa recuperaram a iniciativa e o controlo do combate. Nesta manobra, poucos Ingleses sucumbiram e, ainda por cima, Hardrada foi abatido com uma seta na garganta (o que revela a presença de arqueiros anglo-saxónicos na batalha), sendo também liquidados todos os homens que o rodeavam de perto (cf. Fagrskinna)! O estandarte "Devastador de terras" caiu, e a resistência concentrou-se em torno de Tostig, que parece ter permanecido sempre dentro do círculo defensivo; o Godwin rebelde apelou então a um recuo dos Noruegueses e tentou reorganizar a formação. Nessa altura, Haroldo aproximou-se e terá renovado a sua oferta ao irmão, propondo a paz e prometendo poupar todos os Noruegueses ainda vivos. Todavia, o orgulho dos invasores falou mais alto e Tostig não acedeu. Fez mal: acabou por ser atingido no rosto por um soldado do fyrd, enquanto os últimos resistentes do dispositivo defensivo eram abatidos rapidamente. 
Foi nessa altura que chegaram os reforços noruegueses, sob o comando de Eystein Orri, um dos melhores amigos de Hardrada e seu potencial genro. No entanto, já era demasiado tarde e não tiveram tempo para mais senão para, raivosos por avistarem os corpos dos companheiros mortos, se atirarem aos Ingleses e serem eles próprios massacrados. Parece que Eystein ainda ergueu de novo o estandarte do 'sogro' e que esta última fase da luta foi muito dura, com os Ingleses já cansados de combater - ao todo, a batalha deve ter demorado quatro ou cinco horas. Mas o calor e a fadiga da marcha acelerada também não ajudaram os reforços: alguns despiram as suas defesas de corpo para conseguirem combater e foram também despedaçados. A Fagrskinna diz que esta fase do combate ficou conhecida como "a batalha de Orri", que ali morreu também. Ao que consta, a matança prolongou-se até à noite. As outras fontes, que não as Sagas, não especificam nada disto, limitando-se a uma breve referência à dureza do combate, à sua duração e à derrota final dos Escandinavos. A Crónica Anglo-Saxónica ainda refere um combate entre Ingleses e sobreviventes noruegueses em Ricall, junto aos navios, com incêndios e afogamentos, matéria de que não falam as Sagas.

Deste modo, os Ingleses obtiveram uma vitória importantíssima, ainda que bastante custosa, e, em toda esta operação, desde o momento em que tomou conhecimento da invasão norueguesa pelo Humber, o monarca inglês revelou grande capacidade militar. Perdeu muitos homens, mas não sabemos exatamente quantos; e, de qualquer modo, os Noruegueses perderam ainda mais. Depois de Stamford Bridge, Haroldo marchou com o seu exército para sudeste, até Ricall, onde informou a guarnição dos navios, sob o comando de Olavo e de Paulo, do sucedido: os invasores renderam-se, entregaram reféns e fizeram juramentos, posto o que puderam partir. Explica a Crónica Anglo-Saxónica que os Noruegueses, que tinham entrado em Inglaterra a bordo de pelo menos 300 navios, regressaram em apenas 24 barcos à Noruega... A mesma fonte salienta o facto de muitos desses homens terem travado dois combates no espaço de apenas cinco noites! Quanto a Haroldo II, voltou ao campo de batalha, identificou o corpo do irmão (graças a uma verruga entre as espáduas) e mandou-o sepultar numa igreja de York. A invasão norueguesa tinha chegado ao fim e nada mais havia a temer de Tostig Godwinson. 
Com esta vitória, Haroldo II tinha conseguido reduzir o número dos seus opositores diretos e, além disso, poupar a Inglaterra a mais uma ameaça escandinava. O feito merecia ser celebrado e o rei inglês decerto que o fez com os seus mais próximos, logo que chegaram a York. Porém, não tiveram muito tempo para comemorar ou sequer para lamberem as feridas; é que, como já sabemos, a 28 ou 29 de setembro, ou seja, apenas três ou quatro dias passados sobre a batalha de Stamford Bridge, Guilherme II da Normandia desembarcava em Pevensey e começava a devastar a região do Sussex! Haroldo deve ter sabido desta ocorrência uns três dias mais tarde (isto é, a 1 ou 2 de outubro), através de um estafeta, possivelmente um thegn proveniente de Pevensey, que cavalgou $400 \mathrm{~km}$ durante três dias e três noites até chegar, coberto de lama e de suor, à presença do rei inglês. A notícia era arrepiante: Guilherme desembarcara com uma hoste imensa de cavaleiros, de fundibulários, de arqueiros e de peões, contando com auxiliares poderosos de todas as partes da Gália - assim reza a narrativa de João de Worcester...

\section{A caminho do ordálio}

O rei inglês nem hesitou: reuniu as tropas e avançou para sul, de novo em regime de marchas forçadas, de dia e de noite. A coluna terá alcançado Londres (que era uma boa base e que permitia controlar dois pontos importantes: Dover e Winchester) por volta do dia 5 ou 6 de outubro, se admitirmos que o monarca terá trazido consigo apenas os housecarls e as tropas montadas do fyrd, confiando na sua capacidade para completar o exército assim que chegasse ao sul. No máximo, Haroldo terá permanecido uma semana em Londres, onde concedeu a si próprio e aos seus homens algum descanso e onde entabulou diligências urgentes no sentido de mobilizar as tropas do fyrd nos condados mais próximos, ou seja, nas regiões das Midlands, da East Anglia, do Wessex, do Kent, do Essex e do Sussex. Quando considerou que já tinha um número de homens suficiente para avançar, o monarca marchou para o litoral, em busca do seu adversário. 
Claro que esta foi uma decisão difícil e controversa, e Orderico Vital até sugere que muitos conselheiros do rei inglês procuraram travá-lo, ou pelo menos tentaram evitar que se expusesse pessoalmente em mais um combate. Analisado o assunto a posteriori, isto é, conhecendo-se previamente o resultado da batalha, a decisão do monarca inglês afigura-se temerária e a tendência natural é para o responsabilizar pela derrota. João de Worcester afirma claramente que Haroldo avançou com grande pressa para a Saxónia do Sul, apesar de alguns dos mais bravos ingleses terem sido mortos nas duas batalhas anteriores [Fulford Gate e Stamford Bridge] e de metade do seu exército ainda não ter chegado... Como refere Orderico Vital, se ele tivesse dado tempo ao tempo, a situação de Guilherme tenderia a tornar-se insustentável, por dificuldades de abastecimento; e, esperando alguns dias mais, o monarca teria conseguido reunir uma hoste maior e mais completa.

Tudo isso é verdade, e é impossível não relacionar a falta de arqueiros ingleses na batalha de Hastings (a Tapeçaria de Bayeux representa apenas um, quase insignificante, ainda que possa figurar no bordado como exemplo de um pequeno grupo de atiradores) com a pressa de Haroldo em partir em busca de Guilherme. Mas as decisões têm de ser analisadas com base nos dados de que os atores dispõem no momento de as tomarem! Por um lado, o rei inglês poderia querer surpreender o duque da Normandia, tal como tinha surpreendido Hardrada em Stamford Bridge; e, para tal, não podia perder tempo. Como observou Stephen Morillo, o monarca podia também não acreditar na eficácia de uma verdadeira estratégia de bloqueio, que encurralasse Guilherme no sul da ilha e o privasse de abastecimentos vitais, sobretudo caso não pudesse dispor de imediato de uma frota anglo-saxónica capaz de travar a frota normanda. Além disso, quando saiu de Londres, o monarca inglês pode não ter dado a mobilização por acabada, pois sabemos, através da Crónica Anglo-Saxónica, que ele marcou a reunião dos seus homens num ponto determinado do percurso entre Londres e Hastings, junto a uma "venerável macieira", ou seja, a uma árvore de referência que existia à saída da floresta de Weald, a umas sete milhas (c. de $11 \mathrm{~km}$ ) da costa. A localização desta macieira já foi investigada e aponta-se para o topo da colina de Caldbec, onde hoje existe um moinho de vento; segundo parece, esse local era antigamente um marco de união dos limites de três circunscrições territoriais, chamadas bundreds. Possivelmente, seria conhecido 


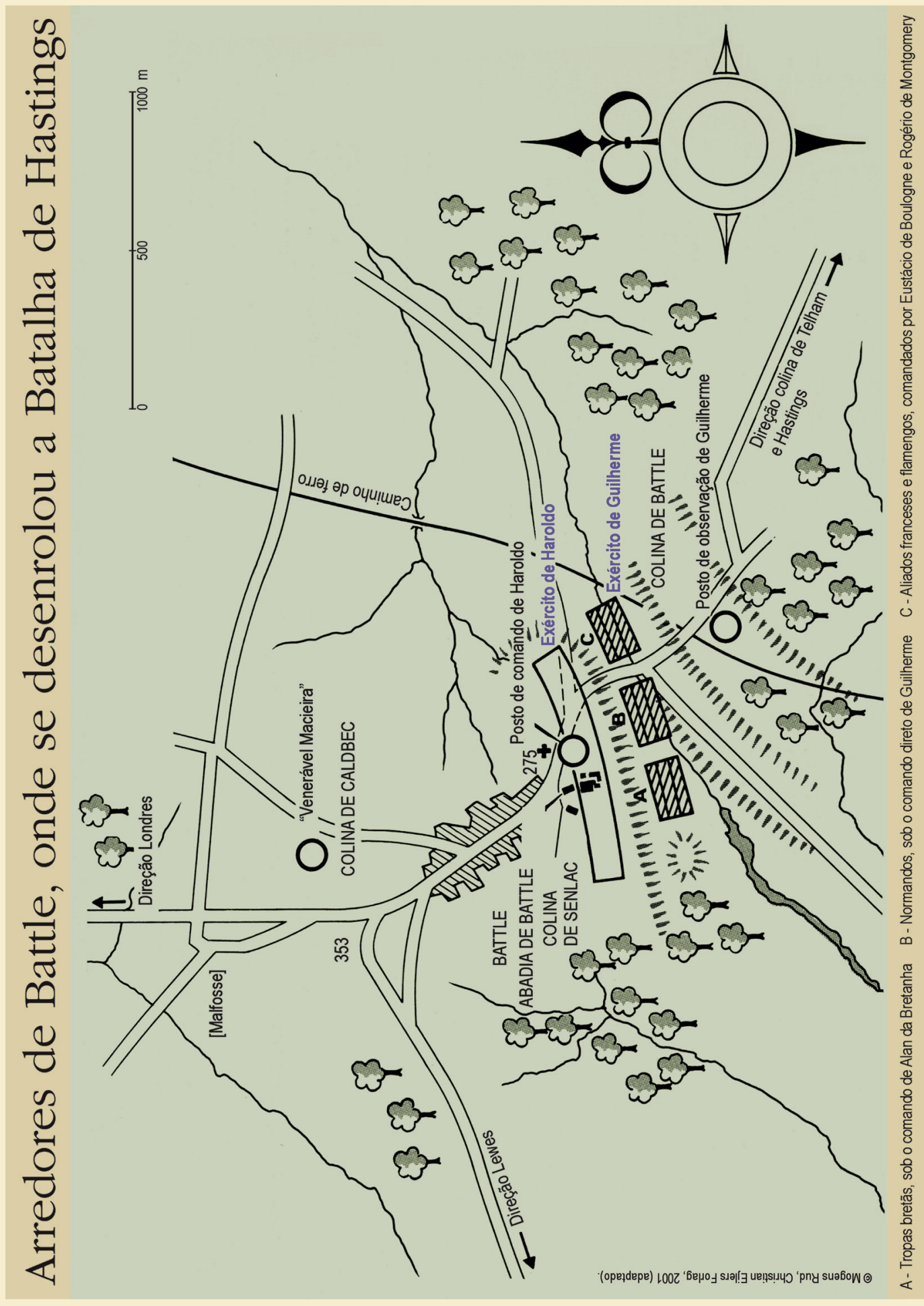


de todos e poderia funcionar como um meeting point para as tropas inglesas, incluindo para as local levies chamadas à pressa nos condados mais a sul, que assim evitariam o esforço de marchar para Londres e, logo a seguir, regressar à região costeira (entre Londres e o terreno onde se travou a batalha distam cerca de 80 a $95 \mathrm{~km}$, dependendo do itinerário escolhido). Haroldo II sentiria também a necessidade de evitar que Guilherme começasse a fazer aliados no sul de Inglaterra, em especial na zona de Winchester, onde o arcebispo Stigand tinha ainda bastante influência (ele que era o conselheiro principal de Ema da Normandia, por via de quem Guilherme reclamava a coroa de Inglaterra), e na Ilha de Wight (que se comprometera em finais de abril com Tostig, e onde a família de Guilherme Fitz Osbern, um dos mais íntimos do duque, possuía terras). Por fim, convém notar que Haroldo trazia consigo de Londres um exército competente, que reunia a nata das forças armadas inglesas (os bousecarls) e uma parte importante das tropas montadas do fyrd, para além de bastante peonagem londrina e dos arredores. Muitos estavam moralizados pela espetacular vitória obtida em Stamford Bridge contra um líder com o prestígio de Harald Hardrada e pareciam decididos a enfrentar o novo invasor, vindo do outro lado da Mancha.

Segundo afirma Guilherme de Jumièges, o rei inglês, "rejeitando a prudência", cavalgou durante toda a noite e alcançou a zona do campo de batalha logo pela madrugada (in Morilllo, p. 18). Com manifesto exagero, Guilherme de Poitiers escreve que a coluna de Haroldo era tão vasta que, “à sua passagem, os rios ficavam secos e as florestas eram reduzidas a planícies" (Parte II, n. ${ }^{\circ}$ 16). Atualmente, estima-se que o exército inglês que combateu em Hastings pudesse ter reunido 10000 homens, reconhecendo-se que a sua principal lacuna foi a falta de arqueiros, que bem úteis poderiam ter sido num combate contra um exército forte em cavalaria, como era o exército normando. Como vimos, os Ingleses fizeram bom uso de arqueiros em Stamford Bridge (o próprio Hardrada morreu atingido por uma seta na garganta), e é um pouco difícil de explicar esta (quase) ausência. Seria o tiro com arco menos popular no sul de Inglaterra, nesta época? Teria Haroldo desvalorizado a importância dos arqueiros num combate que pode ter sido planeado para ser um ataque de surpresa? Haveria contingentes de arqueiros ainda por chegar à "venerável macieira" no momento em que se 
iniciou a batalha (João de Worcester afirma que a batalha foi ferida antes de uma terça parte do exército inglês estar em ordem para combater, e a versão E da Crónica Anglo-Saxónica sugere o mesmo, ao dizer que o combate começou antes de todo o exército inglês ter chegado ao campo de batalha)? Não sabemos ao certo. Segundo Guilherme de Poitiers, a hoste inglesa contaria, em contrapartida, com algumas forças dinamarquesas, o resultado natural de serem seus "aliados de sangue".

Vejamos agora o que se passou, entretanto, do lado contrário. Ainda segundo Guilherme de Poitiers - o nosso principal informador nesta matéria -, quando estava em Hastings, o duque recebeu uma mensagem alarmista de Roberto Fitz Wimarc, dando conta da vitória inglesa em Stamford Bridge e anunciando a marcha de Haroldo rumo ao sul, a alta velocidade; segundo Wimarc (que, como vimos, era normando, ou bretão, e fora íntimo de Eduardo "o Confessor"), Guilherme deveria evitar travar batalha com o rei inglês, que tinha reunido um exército poderoso para o derrotar; melhor seria abrigar-se por detrás dos muros de uma fortaleza. Em resposta, o duque terá dito que a sua opção era outra: preferia combater de imediato Haroldo, o que bem podemos compreender, tendo em conta o adiantado da época e a necessidade de conseguir um sucesso rápido para evitar um drama logístico. Por esta altura, explica Poitiers, o duque recebeu também um monge-mensageiro enviado pelo rei inglês (o que não deixa de ser paradoxal, se admitirmos que este pretendia apanhar o seu inimigo de surpresa!): o monge lembrou-lhe que Eduardo oferecera o trono de Inglaterra a Haroldo no seu leito de morte, o que tinha prioridade sobre todas as promessas e juramentos que anteriormente Eduardo e o próprio Haroldo pudessem ter feito a Guilherme. Este respondeu enviando ao monarca inglês um padre normando de Fécamp, com um discurso que recordava todos os juramentos que lhe haviam sido feitos (por Eduardo, pelos grandes de Inglaterra e por Haroldo, vassalo do duque que o libertara da prisão) e propondo um julgamento justo da questão, segundo a lei inglesa ou a normanda, ou então um duelo judicial em que, para evitar o derramamento de outro sangue, ambos se enfrentassem pessoalmente! Poitiers afirma que, perante esta proposta, Haroldo ficou hesitante e acabou por responder apenas: "Que Deus decida hoje, entre mim e Guilherme, aquilo que é justo" (Parte II, n. ${ }^{\circ} 13$ )... 
Também é oportuno recordar a versão do poema Carmen, que afirma que um monge avisou o duque de que Haroldo o queria apanhar de surpresa e havia feito grandes preparativos terrestres e marítimos, tendo enviado nada menos do que 500 navios para impedir o regresso dos Normandos a sua casa; segundo este emissário, Haroldo trazia florestas de lanças, mas os seus guerreiros eram preguiçosos na arte da guerra, usando penteados untados, e, em combate, mais pareciam ovelhas ou "raposas assustadas com um relâmpago" (in Morillo, p. 46)...

Quanto à Tapeçaria de Bayeux, mostra Guilherme a receber um ajudante de campo, que o informa do avanço de Haroldo: nesta cena, o duque está ainda por equipar e, pela primeira vez, surge com a bandeira trífida cruzetada que o papa lhe enviou. Alertado, Guilherme veste-se a rigor (com capelina de nasal, espada e lança com pendão) e recebe de um palafreneiro o seu corcel de batalha preferido - uma prenda que lhe fora oferecida pelo rei Afonso VI de Leão, o avô materno do nosso D. Afonso Henriques.

Temos assim que, se Haroldo II pretendeu surpreender Guilherme, o plano fracassou. De imediato, a hoste normanda assistiu a uma missa, rezou, organizou-se e partiu para noroeste em busca do adversário, utilizando a velha estrada romana que conduzia a Londres. Caso não muito vulgar na Idade Média, os dois generais desejavam ardentemente travar combate e não fizeram qualquer esforço para o evitar!

Segundo Guilherme de Poitiers, a coluna de marcha normanda que abalou logo pela madrugada do dia 14 de outubro era encabeçada pelas forças de infantaria equipadas com arco e com besta [chamamos a atenção para a presença de bestas neste combate, facto geralmente ignorado], seguidas pelos corpos de infantaria pesada equipada com lorigas e, a fechar, os esquadrões de cavalaria, no meio dos quais seguia Guilherme com a força principal, de modo a poder comandar o conjunto da hoste com a sua mão e com a sua voz gutural. A tapeçaria, pelo seu lado, apresenta a cavalaria normanda a avançar, em fila cerrada, com Guilherme à cabeça, munido de um bastão ou de uma maça semelhante a um ceptro, peça que conservará durante a batalha. A determinada altura, o precioso bordado mostra Guilherme a perguntar a um batedor (identificado como sendo "Vital", provavelmente um homem da Casa do bispo Odão) se tinha visto o exército inglês; o estafeta 


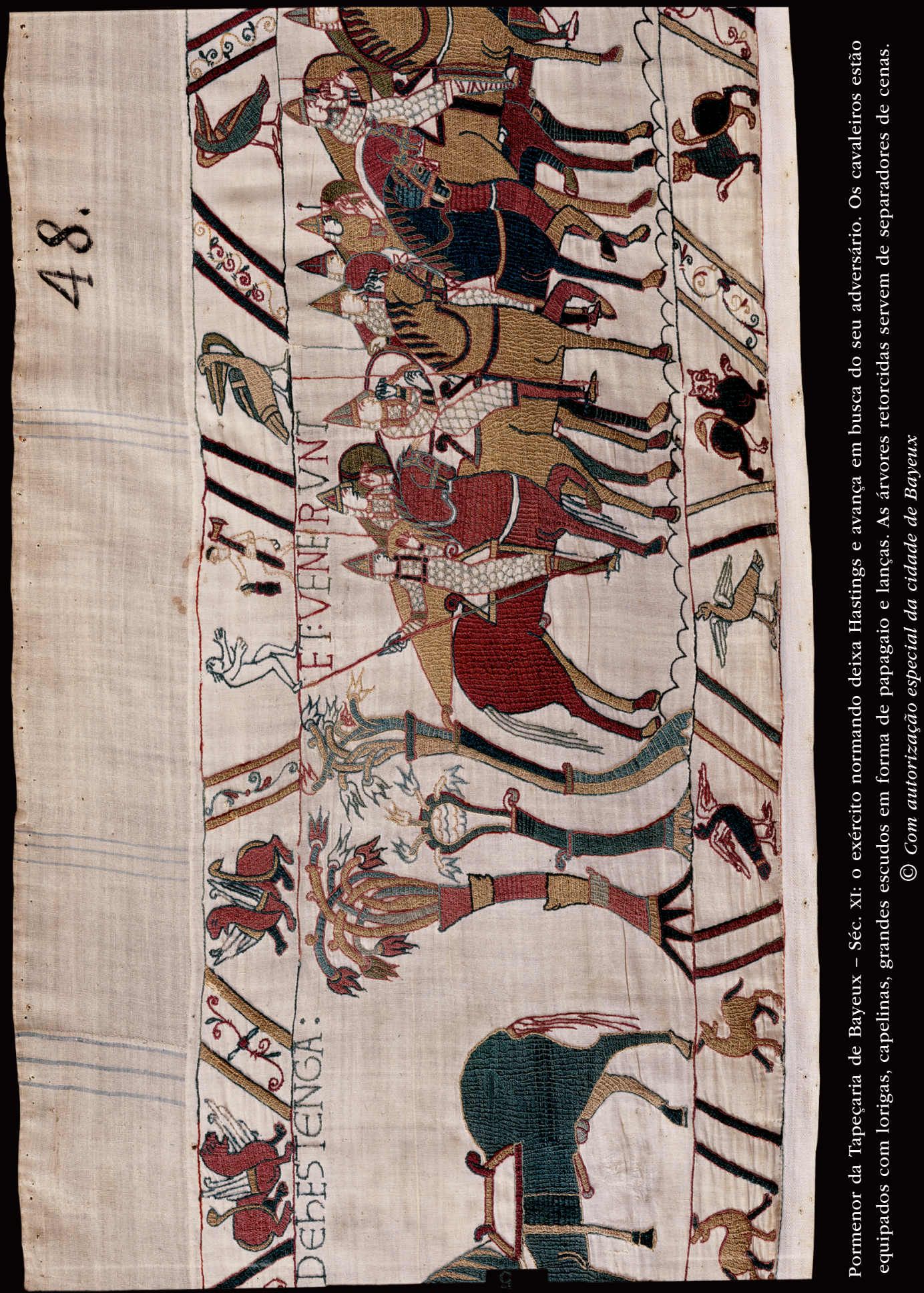


responde apontando para trás. A seguir, vê-se uma patrulha normanda que parece alcançar uma colina (provavelmente Telham Hill), posição a partir da qual já consegue avistar os postos avançados ingleses. Do outro lado das árvores, uma sentinela inglesa espreita o inimigo, espiando na direção sudeste; mantém uma mão à frente dos olhos, por causa do sol matinal: serão, talvez, 8 horas da manhã. Um companheiro vai advertir Haroldo, muito excitado, de que os Normandos foram avistados. O rei, a cavalo, fica com uma expressão muito tensa e aponta para diante. Afinal, quem surpreendeu quem naquela madrugada de sábado, dia 14 de outubro de 1066?...

Como dissemos, na noite anterior os Ingleses tinham alcançado a floresta de Weald, situada ao norte da elevação mais tarde chamada (por Orderico Vital) "colina de Senlac" (isto é, "lago de sangue" ou, segundo outra interpretação, "lago de areia"), uma elevação de cerca de 600 a 800 metros, virada a sul e localizada cerca de 15 a 20 metros acima de uma zona de campina. Todos tinham desmontado e passado ali o resto da noite: segundo Guilherme de Malmesbury, os Ingleses consumiram a noite a cantar e a beber (contrariamente aos Normandos, que, segundo Guilherme de Jumièges, mantiveram o seu exército em armas desde o crepúsculo até à alvorada, prevenindo qualquer ataque inglês à sua posição em Hastings). Guilherme de Poitiers adianta que, não ousando enfrentar o duque em condições de igualdade, os Ingleses tomaram posição num terreno elevado, num monte próximo da floresta de onde tinham saído; de imediato, desmontaram e formaram a pé numa densa unidade. O Carmen descreve esta operação num estilo particularmente expressivo: diz que os Normandos podiam ver os Ingleses não muito longe, com a floresta a brilhar repleta de lanças; subitamente, o bosque começou a despejar tropas, e uma hoste avançou em ordem cerrada (o costume entre os Ingleses, comenta o poeta) e tomou posição num outeiro perto da floresta, com um vale por vizinho e o terreno por cultivar, por ser muito áspero. Neste ponto, o Carmen comenta com acidez a tática de Haroldo, dizendo que os Ingleses são uma raça ignorante da guerra, pois "desprezam o conforto dos cavalos" e gostam de combater a pé, confiando na sua força e encarando como "uma honra suprema" a possibilidade de morrerem de armas na mão (in Morillo, p. 46). Assim, explica o poeta, Haroldo subiu ao monte, reforçou as alas com nobres e 


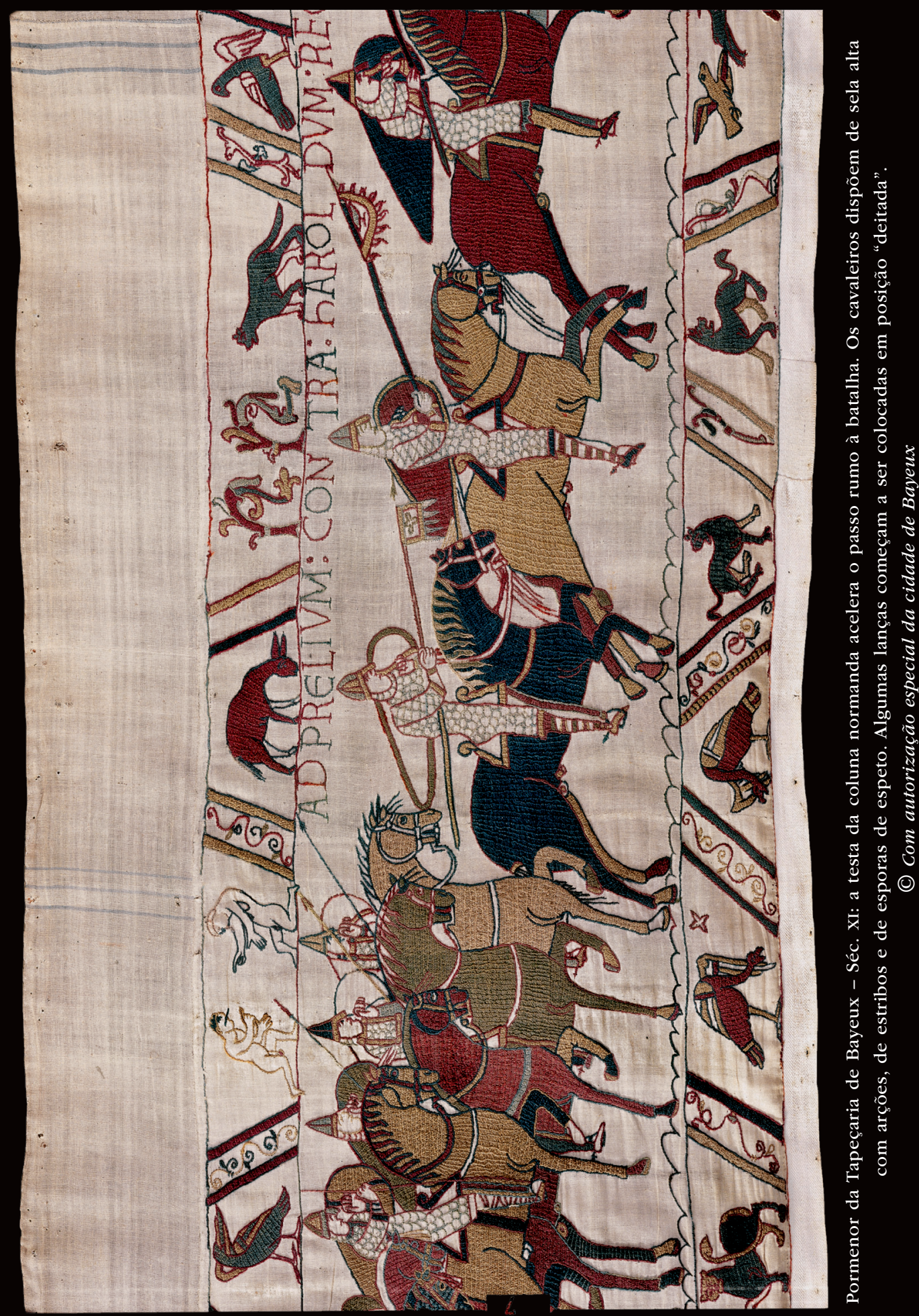


cravou no terreno a sua bandeira [o dragão dourado do Wessex] e os outros estandartes. Todos desmontaram, enviando os cavalos para a retaguarda, e ocuparam as suas posições apeadas, posto o que as trombetas deram o sinal para a batalha. Indiferentes à aspereza do terreno - completa Guilherme de Poitiers -, os Normandos e os seus homens começaram a subir lentamente a encosta. A maior batalha da história medieval europeia ia começar!

\section{A batalha}

Segundo a Tapeçaria de Bayeux, o duque da Normandia, com a batalha iminente, ergueu a sua maça de armas e exortou os seus homens a prepararem-se virilmente para o combate. Neste bordado, podemos desde já perceber a importância que os arqueiros normandos tiveram na refrega, desde a primeira hora: estes atiradores utilizavam arcos de madeira fabricados de uma só peça, como sucederá com o célebre longbow (o "arco longo") inglês, que se imporá nos campos de batalha do séc. XIV, em especial na Guerra dos Cem Anos. Conforme se pode ver pelas representações da tapeçaria, estes arcos eram, basicamente, varas afiladas com os extremos ligados por uma corda e eram manejados sobretudo por combatentes de baixa cotação social, sumariamente equipados.

Conjugando as informações das diversas fontes, admite-se geralmente que o exército normando, depois de ultrapassar a colina de Telham, abandonou a estrada em que seguia, obliquou para a esquerda e desdobrou o seu exército para formar em ordem de batalha. O dispositivo normando, situado no vale compreendido entre a colina de Telham e a posição anglo-saxónica, devia comportar duas linhas principais: uma linha mais adiantada, com infantaria ao centro e arqueiros e besteiros nas alas; e uma linha mais recuada, com as tropas de cavalaria segmentadas em três blocos: ao centro, Guilherme e o seu núcleo duro de tropas normandas; à esquerda, a cavalaria bretã, sob a liderança de Alan Fergant (genro de Guilherme, por via do seu casamento com Constança); à direita, a cavalaria flamenga e 'francesa' (isto é, da Île-de-France), sob o comando de Eustácio de Boulogne e de Rogério de Montgomery. Não há acordo quanto aos efetivos de Guilherme da Normandia (Poitiers fala em 60 000, o que é completamente impossível), 
mas estimativas recentes, como a de Philip Morgan, situam-nos em torno dos 7000 a 8000 combatentes, entre os quais 2000 cavaleiros, o que nos parece razoável. Note-se que os cavalos normandos, trazidos de propósito do continente, eram animais muito robustos e criados especificamente para a guerra: não se assustavam com o clamor da batalha e eram, eles próprios, uma 'arma de guerra' - o seu impacto derrubava os oponentes e os seus cascos provocavam grandes estragos nas linhas inimigas. A frente do exército normando deveria ter, no total, uns 800 a 1000 metros.

Observando hoje o terreno, irregular, inclinado e 'áspero', com pântanos e bosques laterais a restringir o campo de batalha nos flancos, percebemos como terá sido difícil a Guilherme dispor as suas tropas de uma forma minimamente coesa e uniforme. Seguramente, a sua tática consistia em fragilizar primeiro a parede defensiva anglo-saxónica mediante uma investida da infantaria, acompanhada por uma saraivada de disparos dos atiradores com arco e com besta; depois, seria a vez da cavalaria investir, encosta acima e com o maior ímpeto possível, carregando tantas vezes quantas fosse necessário sobre a formação cerrada inimiga, o que implicaria reagrupamentos sucessivos e uma boa temporização dos ataques.

Quanto aos Ingleses, depois do agrupamento junto à "venerável macieira", avançaram um pouco para sul e formaram uma extensa parede de escudos (com 4 a 10 fileiras de profundidade), com o rei, os bousecarls (talvez uns 1000) e os lanceiros na zona central, e as tropas do fyrd nas alas. No entanto, é provável que Haroldo tenha querido reforçar os flancos, entremeando aí algumas das suas melhores tropas. Admitimos também que os seus dois irmãos, Gyrd e Leofwine Godwinson, se tenham posicionado mais sobre as zonas laterais, de maneira a assegurarem um melhor comando desses setores, sempre sujeitos a tentativas de envolvimento pela cavalaria adversária (ainda que em Hastings isso não fosse muito fácil, dadas as características do terreno). De uma forma geral, os Anglo-Saxões que combateram ao lado de Haroldo na colina de Senlac eram guerreiros duros e experientes, muitos dos quais tinham servido com ele no País de Gales, em 1063, e em Stamford Bridge: tratava-se de uma das melhores infantarias europeias e não iria deixar os seus créditos por mãos alheias. Mais atrás, numa segunda linha ou reserva, o rei pode ter disposto um núcleo de tropas de apoio recrutadas entre a peonagem dos fyrdmen, equipada so- 
bretudo com lanças fabricadas com madeira de freixo. Os poucos arqueiros disponíveis podem também ter sido colocados nesta zona do dispositivo, eventualmente nas alas.

Vale a pena acrescentar que a opção de Haroldo por uma postura apeada não resulta - ao contrário do que o Carmen sugere - de uma teimosia ou de uma qualquer 'prática sagrada' dos Anglo-Saxões. Hoje, sabe-se que a ideia de que os exércitos anglo-saxónicos da Alta Idade Média combatiam sempre a pé, embora pudessem viajar a cavalo para o campo de batalha, não passa de um mito. Poucas batalhas podem, eventualmente, sustentar essa ideia: além de Hastings, apenas Hereford-1055, contra os Galeses, Ashingdon-1016, contra Cnut, e Maldon-991, contra os Vikings; nestes três últimos casos, a leitura das fontes até admite outras interpretações. Como demonstrou Guy Halsall, o que sucede é que os historiadores dos sécs. XIX e xx generalizaram excessivamente a ideia do combate apeado na Inglaterra dos sécs. X e XI e, pior do que isso, retroprojetaram esta tese sobre todo o período anterior. A ideia de que os Anglo-Saxões nunca lutavam a cavalo tornou-se, portanto, uma 'ideia feita', que passou de geração em geração. Aliás, os túmulos anglo-saxónicos do séc. VII mostram cavalos e arneses de montadas; diversas descrições escritas sugerem que o equipamento do guerreiro incluía necessariamente o cavalo; a nobreza e a realeza anglo-saxónicas eram tidas como tão 'cavaleirescas' quanto as suas homólogas continentais; as próprias exigências legais do séc. XI estipulavam a presença de um cavalo no equipamento dos guerreiros; e também as fontes pictóricas apontam no mesmo sentido. Isto não significa que os Anglo-Saxões nunca combatessem a pé; claro que também o faziam e até é possível que os ataques dos Vikings tenham levado a um reforço dessa tendência. Ou seja, a "parede de escudos" pode ter sido mais vulgar no período anglo-saxónico tardio do que antes. Pode também ser que, até aos finais do séc. X, os Anglo-Saxões lutassem menos frequentemente a cavalo do que os guerreiros continentais, ou que tenham sido mais lentos do que os Francos ou os Normandos a desenvolver uma verdadeira cavalaria de choque. Mas nada disso permite concluir que os guerreiros anglo-saxónicos não fossem capazes, ou não estivessem disponíveis para fazer aquilo que os seus homólogos continentais faziam: lutar a cavalo quando as circunstâncias o exigiam. 


\section{Hastings (1066)}

Fase 1: Abertura

Tropas de Apoio

\section{Fyrd \\ Housecarls \\ e Lanceiros \\ HAROLDO \\ Housecarls \\ e Lanceiros \\ Fyrd}
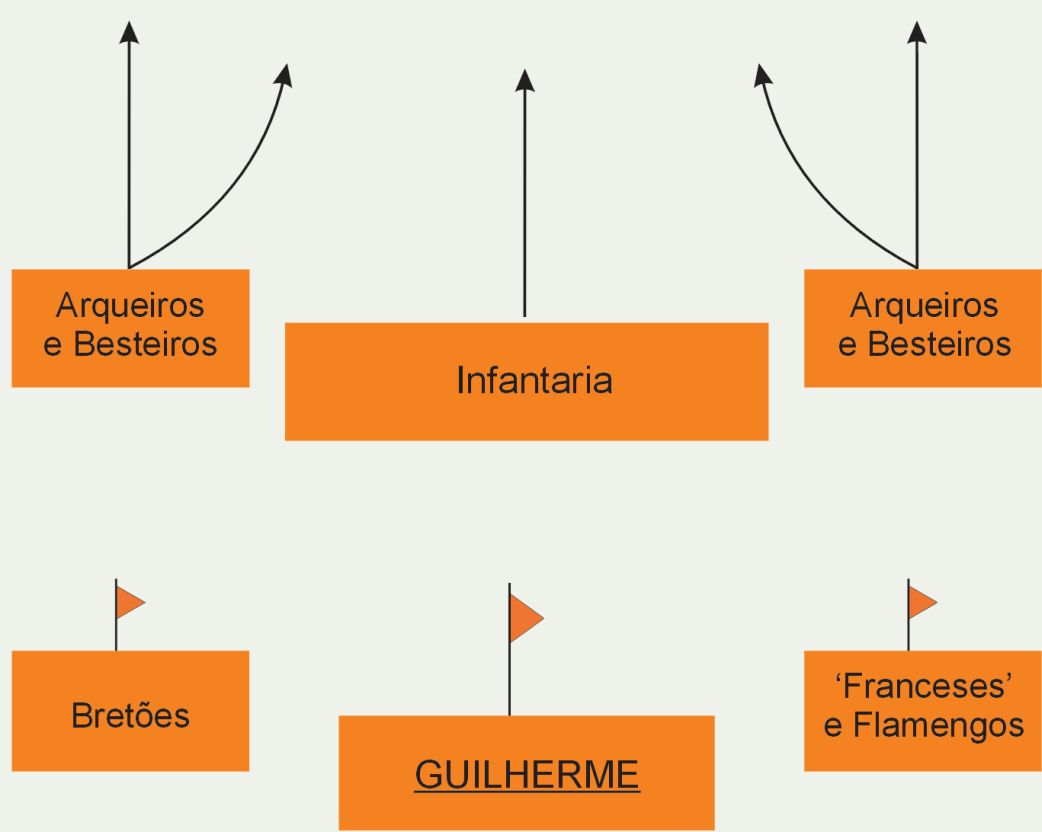

Os atiradores, primeiro, e a infantaria de Guilherme, depois,

Ingleses abrem as hostilidades, atacando a formação cerrada anglo-saxónica. O ataque é duramente repelido e vai obrigar a Normandos cavalaria normanda a avançar pela encosta acima, em socorro das tropas apeadas. 
Em Hastings, se Haroldo II mandou apear a sua tropa foi certamente porque ocupava uma posição no cimo de uma cumeeira íngreme e porque enfrentava um exército normando que o rei inglês já sabia, por ter feito campanha ao lado de Guilherme (em 1064, na Bretanha), que era formado por excelentes cavaleiros. Ao mandar desmontar os seus homens, Haroldo terá querido anular o poder de choque da cavalaria normanda, formando uma 'parede' em que a sobreposição dos escudos definia uma autêntica fortificação de campo, quase impossível de penetrar. O que o rei inglês não pretendeu, seguramente, foi obedecer cegamente a uma qualquer 'tradição anglo-saxónica' - que, de resto, nem sequer tinha respeitado em Stamford Bridge, onde os Ingleses atacaram montados... Haroldo apostou foi num bom modelo tático que, como veremos, quase lhe dava a vitória.

Se o plano inicial fora o de surpreender Guilherme em Hastings, o monarca inglês podia dar-se por bastante satisfeito por ter encontrado pelo caminho um terreno de recurso que lhe garantia uma posição muito confortável para combater. O facto de sabermos que Haroldo agendou a concentração dos seus homens para a zona da "venerável macieira" leva-nos a admitir que esse 'plano B' poderá ter sido considerado previamente, na suposição de virem a surgir notícias dos batedores ingleses dando conta do avanço da hoste normanda na direção de Londres. Como quer que tenha sido (bem avisámos de início que Hastings permanece um mar de interrogações!), no local onde dispôs a sua hoste Haroldo barrava a marcha do exército de Guilherme, que assim se via forçado a optar entre o risco de ficar encurralado a sul e a necessidade de travar batalha em condições orográficas desfavoráveis.

A narrativa mais completa e mais verosímil do combate é a de Guilherme de Poitiers. Descontando a sua retórica classicista e os elogios desmedidos à atuação de Guilherme, que compara aos antigos heróis da Grécia, podemos seguir de perto a sua descrição da batalha. Pontualmente, completá-la-emos com os relatos das outras fontes que selecionámos como as mais importantes.

Segundo Guilherme de Poitiers (Parte II, n. ${ }^{\circ} 17$ ) - e as restantes fontes concordam com isto -, foi "a audácia dos Normandos" que abriu o combate. Seriam, talvez, 9 horas da manhã, pois Guilherme de Jumièges refere que a batalha "começou à terceira hora do dia" (in Morillo, p. 18). A peonagem normanda atacou os Ingleses "por meio de mísseis", o que faz supor que terão sido os arqueiros e os besteiros a iniciar as hostilidades. O Carmen 


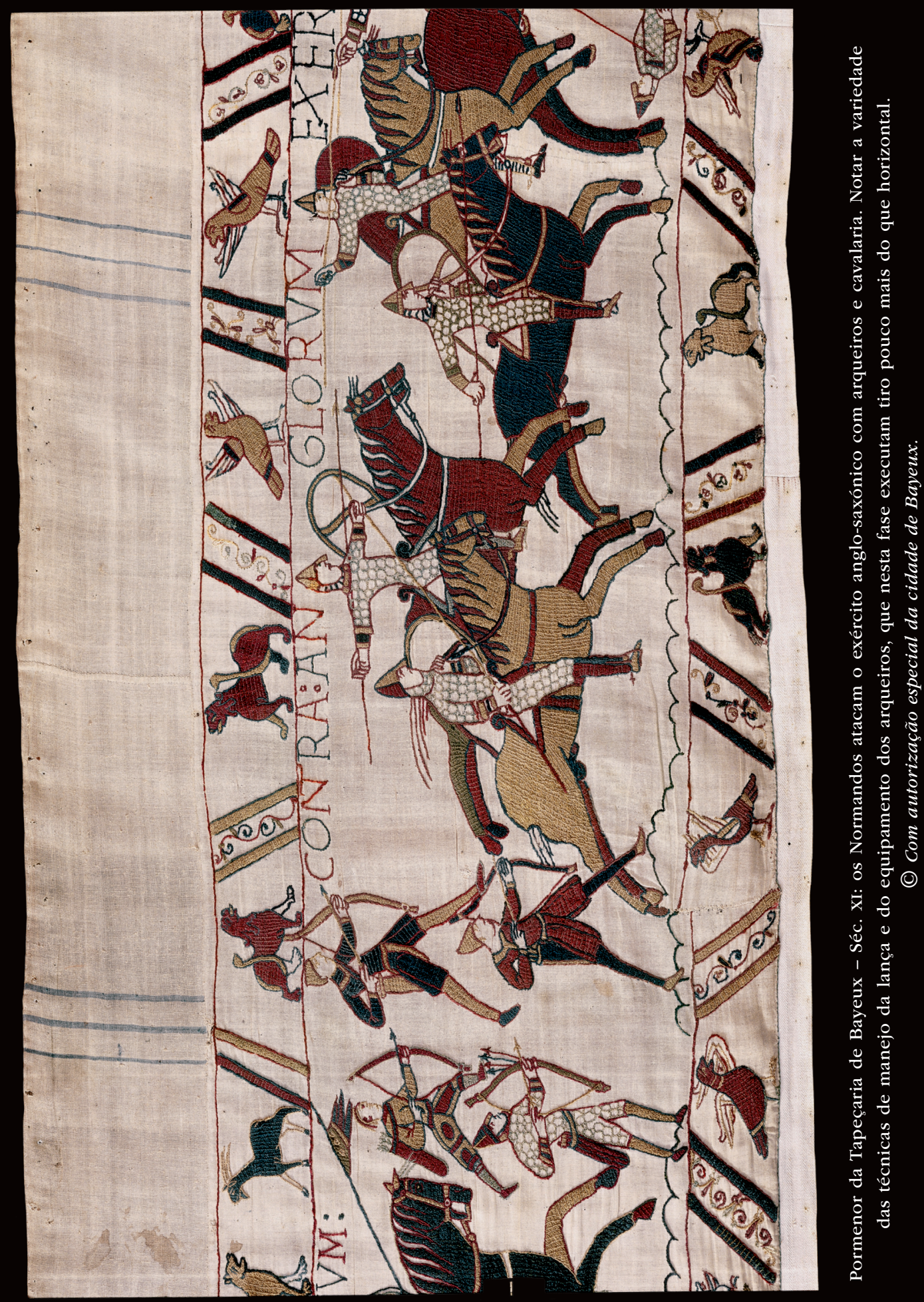


confirma esta ideia, ao dizer que o duque mandou avançar os atiradores para que estes pudessem atingir os Ingleses no rosto, fazendo-os recuar. A observação faz sentido, porque o rosto era justamente uma das zonas que os arqueiros e os besteiros podiam alvejar, por não se encontrar protegida pelas defesas de malha metálica. O poeta explica ainda que os escudos ingleses eram impotentes perante os projéteis das bestas e afirma que os arqueiros trespassavam os corpos e que os besteiros destruíam os escudos como uma "tempestade de granizo" (in Morillo, p. 47). No entanto, afirma Guilherme de Poitiers, os Ingleses resistiram corajosamente a este assalto, secundado pela infantaria, cada um dos Anglo-Saxões fazendo valer as suas capacidades: uns arremessavam lanças e dardos, outros machados muito pesados e contundentes, outros ainda "pedras agarradas a hastes de madeira" (a tapeçaria mostra um género de maça a voar em direção ao exército normando, a par de uma lança, e nas proximidades do único arqueiro representado). Desta forma, a situação complicou-se para os Normandos, de tal modo que, caso o combate tivesse prosseguido no mesmo registo, "os nossos seriam imediatamente esmagados por tudo isto, tal como por uma massa mortífera" (G. Poitiers, Parte II, n. ${ }^{\circ}$ 17). Portanto, o duque mandou rapidamente avançar a sua cavalaria, até porque - como observou Kelly DeVries (2006) - não era muito honroso atrasar a sua intervenção num combate daquela responsabilidade...

Por volta das 9h30, os cavaleiros de Guilherme avançam em socorro das suas linhas mais adiantadas, pelo que "aqueles que antes estavam na retaguarda tornam-se os primeiros" (Parte II, n. ${ }^{\circ}$ 17). A Tapeçaria de Bayeux mostra os cavaleiros normandos a passar ao galope, uns empunhando as suas lanças bem alto, como se as quisessem arremessar, outros colocando-as sob as axilas, na posição de 'lança deitada', que mais tarde imortalizará as cargas da cavalaria europeia (em especial na Terra Santa e na Península Ibérica). Todavia, Guilherme de Poitiers afirma que, com vergonha de combater à distância, provavelmente através do arremesso de lanças, os cavaleiros normandos "ousam travar combate com as espadas".

Ergue-se, deste modo, no campo de batalha um clamor imenso, "aqui normando, ali estrangeiro (...) abafado pelo ruído das armas e pelos gemidos dos moribundos" (Parte II, n. ${ }^{\circ}$ 17). Segundo dirá Wace no Roman 


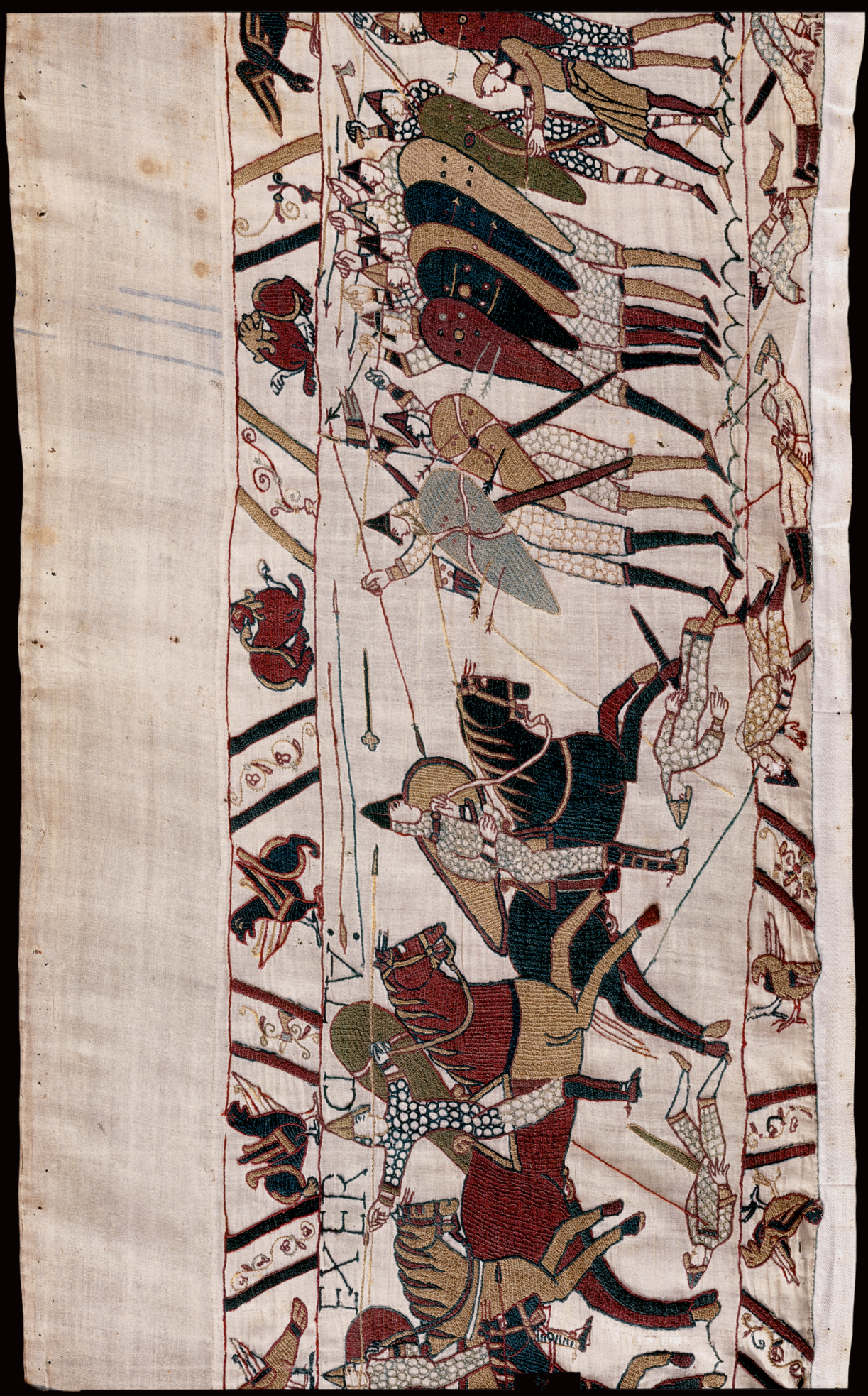

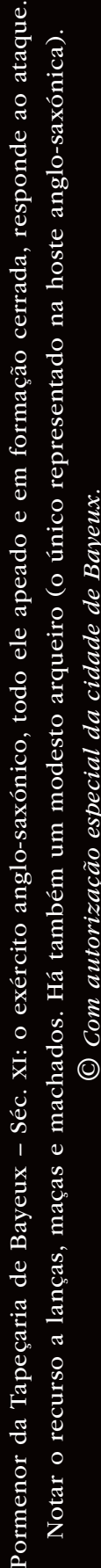


de Rou, o grito de guerra dos Normandos era "Diex aïe!" ("Deus nos ajude!"), enquanto os Ingleses gritavam simplesmente "Ut, ut!" (isto é, "out!": "fora!"); como comenta Mogens Rud, este grito dos Ingleses devia tornar o som emitido pela parede de escudos anglo-saxónica comparável ao de uma matilha acirrada a ladrar...

Neste combate tão violento, explica Guilherme de Poitiers que os Ingleses são "bastante ajudados pela vantagem de uma posição mais elevada, que ocupam sem se deslocarem e em formação muito cerrada, bem como pelo seu grande número e corpos robustíssimos”. Além disso, os Ingleses dispõem de uma outra vantagem: a qualidade das suas armas, "que facilmente encontram uma passagem através de escudos e de outras proteções". Graças a isto, os combatentes de Haroldo conseguem repelir o ataque dos adversários que os acometem de espadas na mão; e conseguem mesmo ferir "aqueles que, à distância, arremessam dardos contra eles".

A formação de Guilherme começa a acusar fortemente as dificuldades e eis que, "aterrorizados por esta violência, os peões, bem como os cavaleiros bretões e quantos auxiliares estavam no flanco esquerdo, se põem em fuga". O efeito propaga-se de imediato e "quase toda a linha do duque cede", perseguida por grande número de adversários. Ainda por cima, "os Normandos acreditaram que o seu duque e senhor tinha tombado" (Parte II, n. ${ }^{\circ}$ 17)!

É possível que o boato da morte de Guilherme esteja relacionado com o facto de a sua montada ter sido abatida - o que, segundo Guilherme de Poitiers afirma um pouco mais à frente, aconteceu por três vezes durante a batalha. Também pode ter havido alguma confusão de identidades pois, como lembra Kelly DeVries, antes da vulgarização da heráldica os cavaleiros bem armados ficavam parecidos uns com os outros dentro dos seus equipamentos.

O rumor da morte do duque deve ser verídico, pois a tapeçaria mostra claramente Guilherme a levantar a sua proteção de cabeça (uma capelina com nasal) para mostrar aos seus que está vivo. Poitiers valoriza o incidente e explica que o líder normando, "ao ver que uma grande parte da formação adversária se tinha precipitado para a frente e perseguia os seus, correu ao encontro dos que fugiam e barrou-lhes o caminho, batendo-lhes e ameaçando-os com a lança. E, além disso, descoberta a cabeça após ter levantado o capacete, disse em voz bem alta: 'Olhai para mim. Estou vivo e 


\section{Hastings (1066)}

Fase 2: Pânico entre os Normandos

\section{Tropas de Apoio}

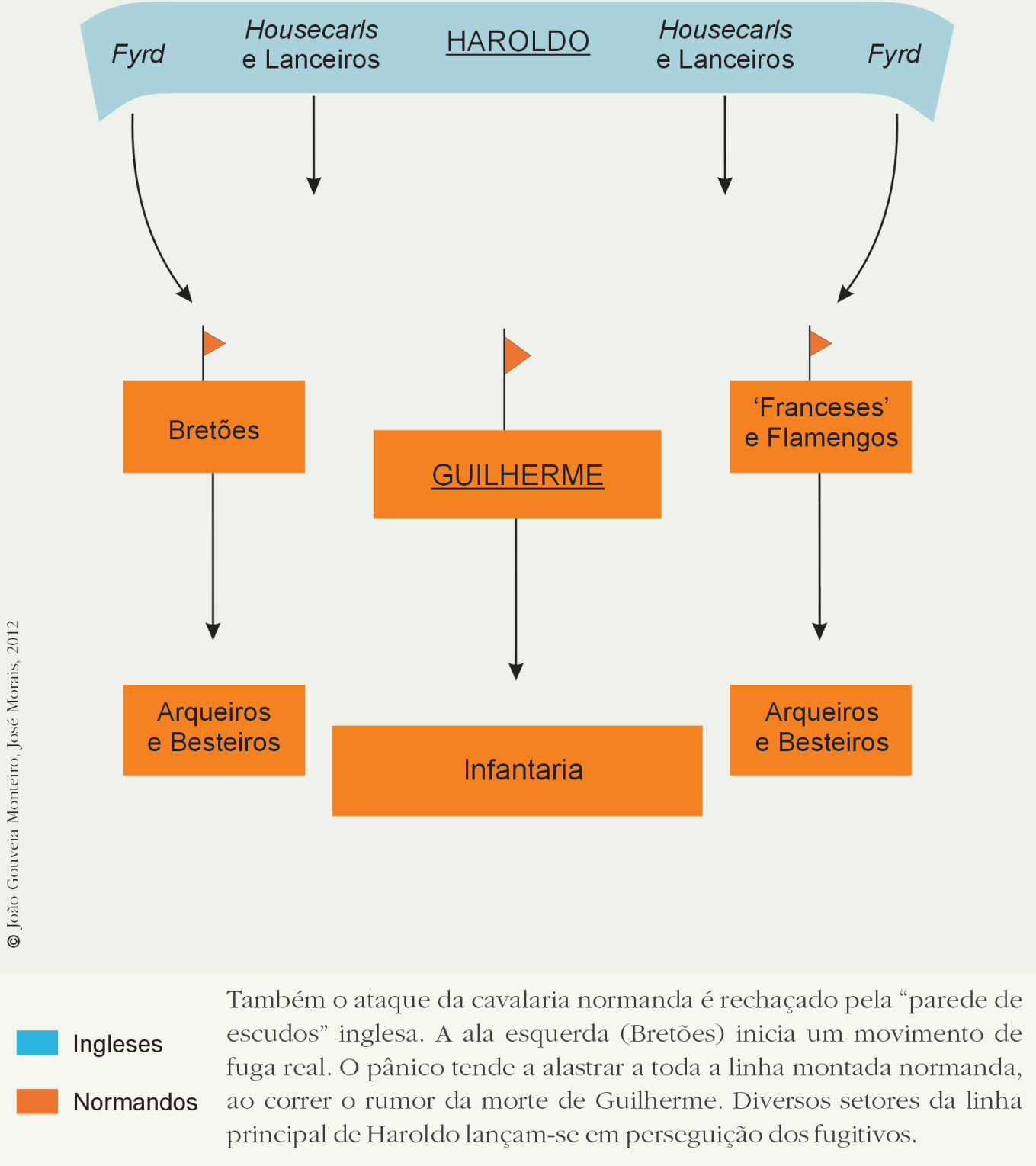


vencerei, com a ajuda de Deus. Que loucura vos leva a fugir? Que caminho se abrirá para a fuga? Podeis abater como gado aqueles que vos repelem e matam. Desperdiçais a vitória e a glória eterna; correis para a ruína e para o opróbrio eterno. Fugindo, nenhum de vós escapará à morte'. Dito isto, eles recobraram o ânimo" (Parte II, n. ${ }^{\circ} 18$ ).

Ultrapassado este momento crítico, que poderia ter liquidado as suas esperanças em vencer a batalha, os Normandos, com o duque à cabeça, travaram a fuga (segundo o Carmen, eles fugiam com os escudos a cobrir-lhes as costas), fizeram meia-volta e, "repletos de ardor e cercando alguns milhares que os tinham perseguido, liquidaram-nos num ápice, de tal forma que nenhum sobreviveu" (Parte II, n. ${ }^{\circ} 18$ ).

Em nossa opinião, este é um dos momentos decisivos do combate. Por um lado, porque os Normandos estiveram à beira do colapso (no nosso entender, esta primeira fuga foi bem real, e não simulada, como sugere o Carmen e defendem alguns autores) e só o evitaram graças à intervenção in extremis de Guilherme. Depois, porque os Ingleses, cuja formação era eminentemente defensiva, desperdiçaram aqui a sua oportunidade de ouro para um contra-ataque fulminante, que teria varrido os inimigos do campo de batalha e lhes teria dado a vitória.

Não é claro por que razão o contra-ataque anglo-saxónico não funcionou, mas tudo indica que ele não foi generalizado, devendo ter envolvido sobretudo os setores do centro-direita, do centro-esquerda e dos flancos da primeira linha de Haroldo; em especial no flanco direito, o avanço inglês deve ter sido pronunciado, porque os cavaleiros bretões, na ala esquerda do duque, parecem ter cedido mais rapidamente. O rei inglês, homem experiente e com talento militar, pode ter hesitado e perdido aqui a oportunidade de um assalto mais generalizado e em força. Ou pode o contra-ataque ter corrido mal por outras razões.

Stephen Morillo sugeriu que este insucesso pode estar relacionado com um facto a que Guilherme de Poitiers não faz referência explícita, mas que a tapeçaria apresenta como tendo ocorrido numa fase ainda inicial da batalha, pouco depois da primeira investida normanda: a morte dos irmãos do rei inglês, Leofwine e Gyrd. É significativo que a tapeçaria os mostre em campo aberto, isolados da parede de escudos, Leofwine empunhando um machado de duas mãos e Gyrd uma lança e um escudo circular; 


\section{Hastings (1066)}

Fase 3: Guilherme salva o dia

\section{Tropas de Apoio}

\section{Fyrd $\begin{aligned} & \text { Housecarls } \\ & \text { e Lanceiros }\end{aligned}$ HAROLDO $\begin{aligned} & \text { Housecarls } \\ & \text { e Lanceiros Fyrd }\end{aligned}$}
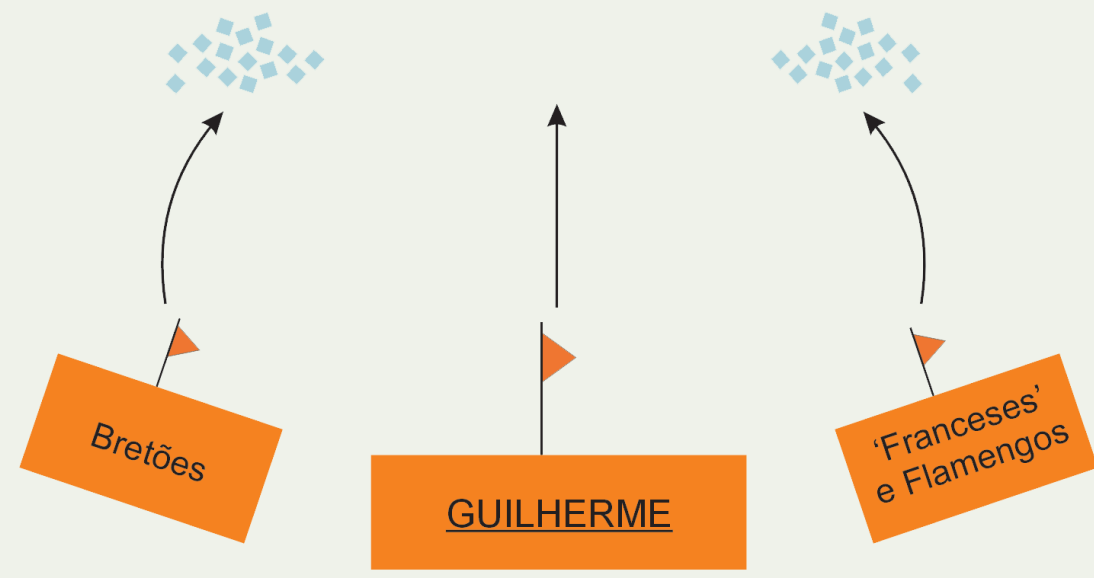

\section{Arqueiros}

e Besteiros

Guilherme mostra que está vivo e estanca a fuga da sua cavalaria. Ingleses

\section{Infantaria}

Arqueiros

e Besteiros

\section{Normandos irmãos de Haroldo (Gyrd e Leofwine). A cavalaria normanda renova} os ataques. 
possivelmente, caber-lhes-ia dirigir, cada qual no seu setor (centro-direita e centro-esquerda, talvez), o contra-ataque anglo-saxónico, mas a sua morte, às mãos de cavaleiros normandos equipados com lança, pode ter comprometido a manobra. Quase logo a seguir, o bordado de Bayeux introduz a cena em que se vê Guilherme a levantar a capelina e a travar os seus homens, secundado por Odão, que maneja energicamente o seu báculo (como clérigo, não podia usar armas) e que procura animar os combatentes. Ou seja, os dois acontecimentos (a morte dos irmãos Godwinson e o reagrupamento normando) são implicitamente relacionados no precioso bordado; pelo meio, temos uma cena muito discutida, em que se vê um pequeno grupo de ingleses no cimo de um outeiro, mal equipados e munidos de lanças e de escudos em forma de lágrima, a atacar os cavaleiros normandos, alguns dos quais são espetacularmente derrubados juntamente com as suas montadas.

Acolhemos, pois, a hipótese postulada por Morillo e também a sua sugestão de que, a partir deste momento, o exército inglês ficou amputado da sua componente ofensiva, devido à morte dos dois principais lugares-tenentes de Haroldo. Para além disso, os Ingleses perderam muitos homens nessa manobra, mesmo que não seja de aceitar os "alguns milhares" de que fala Guilherme de Poitiers, muito menos os "dez mil" mencionados no Carmen. Imaginamos que essa sangria ocorreu sobretudo no flanco direito, que começou a perseguir mais cedo e que pode não se ter apercebido da morte de Gyrd e de Leofwine, e terá, por isso, conduzido a contraofensiva até mais longe. Se a cena do outeiro tem que ver com esta fase do combate - representando um pequeno grupo perseguidor, que preservou a sua coesão e que avançou até mais longe, ou que demorou mais a ser apanhado e cercado -, então compreendemos bem por que motivo os soldados ingleses ali representados estão sumariamente equipados: trata-se de tropas do fyrd, maioritariamente colocadas nos dois extremos da parede de escudos. Aliás, o Carmen, com mal disfarçado desdém, refere que, ao ver a linha normanda ceder, a rustica gens inglesa rejubilou e lançou-se numa perseguição descuidada, adelgaçando a densa floresta da infantaria anglo-saxónica; viram que, à esquerda, "o terreno estava a enfraquecer a ala esquerda do duque" e que, à direita, se abria uma "ampla estrada" para penetrarem e lançaram-se por ali abaixo, cada uma das alas desejando ser a primeira a chacinar os Normandos em fuga (in Morilllo, pp. 47-48). 


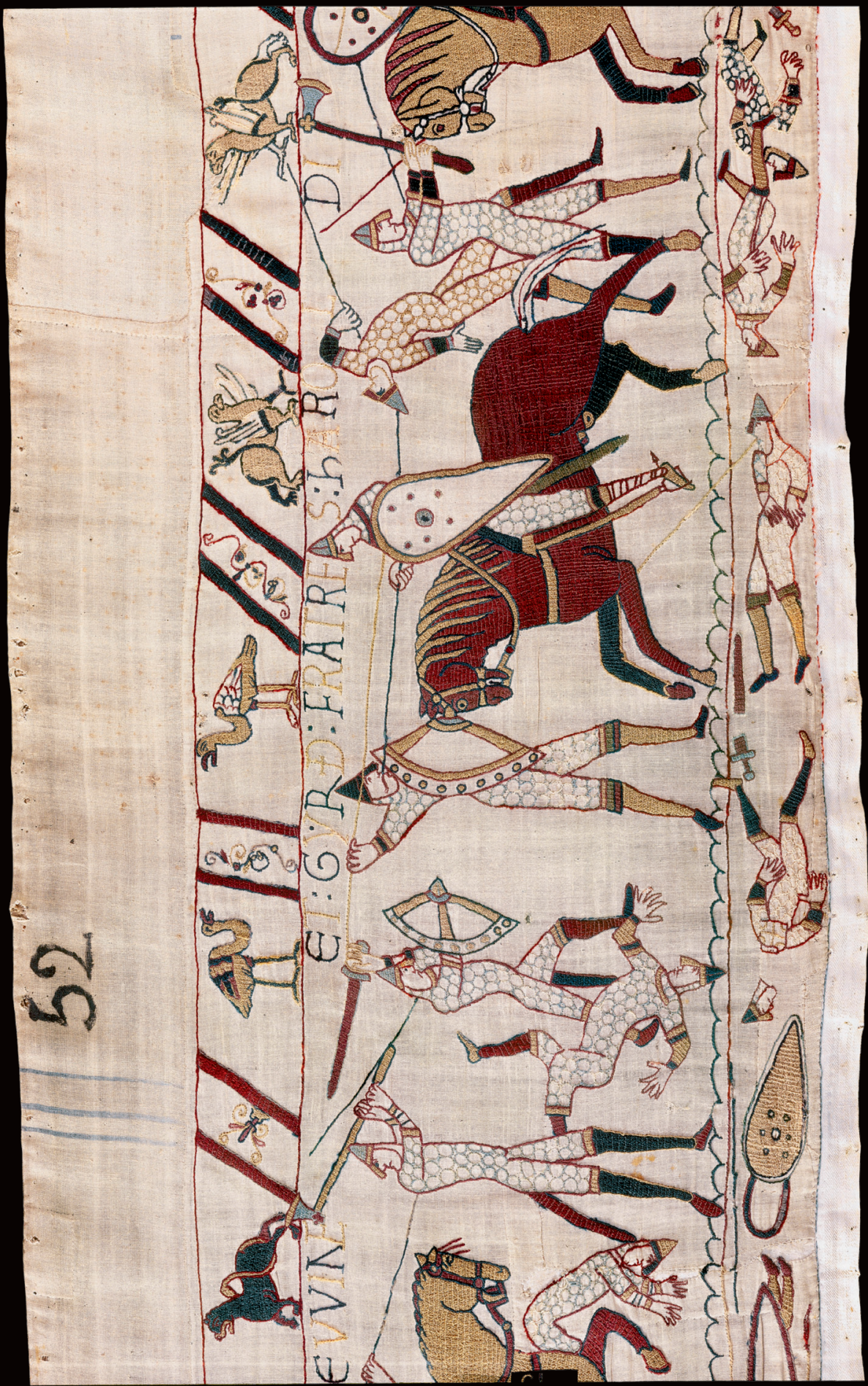

음

흘

울 웅

के

范

토

음

응

可

ब

웅

号

हี छ :

o :

\& 0

है

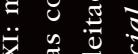

$x$ छ

\& 요

1 .

$x$ 政

0. $\frac{\pi}{2}$

की

ช

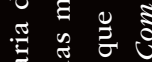

쟁

항

요 울

등

ฮี छ

อ

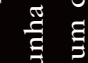

है

를

(1)

క్ 
Seja como for, o certo é que, por volta das 10h30, os Normandos superaram a crise e atacaram com redobrado vigor. O Carmen refere que o seu ímpeto cresceu de tal forma que "a trémula hoste inglesa recua como a cera mole derrete ao fogo" (in Morilllo, p. 49). No entanto, ainda era muito cedo para cantar vitória. Como explica Guilherme de Poitiers, a hoste anglo-saxónica, apesar de ter sofrido "enormes baixas", não parecia diminuída e lutava com todo o ardor, "esforçando-se sobretudo em não abrirem nenhuma brecha aos que desejavam penetrar": a parede de escudos continuava bastante cerrada, de tal maneira que "os seus mortos mal podiam cair" por falta de espaço (Parte II, n. ${ }^{\circ}$ 19)! Afirma o poeta do Carmen que os Ingleses rejeitavam submeter-se às espadas dos adversários como os javalis com as suas presas e com as mandíbulas espumantes resistem quando acossados pelos cães de caça, sem temerem nem os opositores, nem as lanças que os ameaçam de morte (in Morillo, p. 47)...

Então, Guilherme optou por recorrer a um estratagema que era bem conhecido dos Normandos, que já o haviam utilizado em Messina (em 1060) e, como vimos, em Saint-Aubin-sur-Scie, em 1053, contra o rei Henrique I de França e sob o comando de Gualter Giffard. Conforme explicou Bernard Bachrach, a fuga (ou retirada) simulada constituía uma parte bem consolidada do repertório tático da França ocidental: o procedimento fazia parte da herança dos Alanos, estabelecidos nas Gálias antes da fixação dos Normandos em França (tratado de Saint-Clair-sur-Epte, em 911); com a sua argúcia na arte militar, os Normandos depressa assimilaram a manobra e utilizaram-na pelo menos três vezes, entre 1053 e 1066. Acresce que Gualter Giffard combateu em Hastings, ao lado de Guilherme, assim como muitos dos que tinham servido na Sicília em 1060. O bom resultado que tinham obtido um pouco atrás, quando reagruparam por ordem expressa do duque e carregaram sobre os seus perseguidores, chacinando-os, estimulou-os a ensaiar uma manobra do mesmo género, mas agora planeada (uma manobra ditada pela "malícia", como diz o Carmen).

Explica Poitiers (e várias outras fontes o confirmam neste passo, para além do Carmen: Orderico Vital, Guilherme de Malmesbury, a Crónica da Abadia de Battle) que, "ao reconhecer que não podiam vencer um inimigo tão numeroso e, ao mesmo tempo, tão resistente, os Normandos e 


\section{Hastings (1066)}

Fase 4: Cargas e fugas simuladas

\section{Tropas de Apoio}

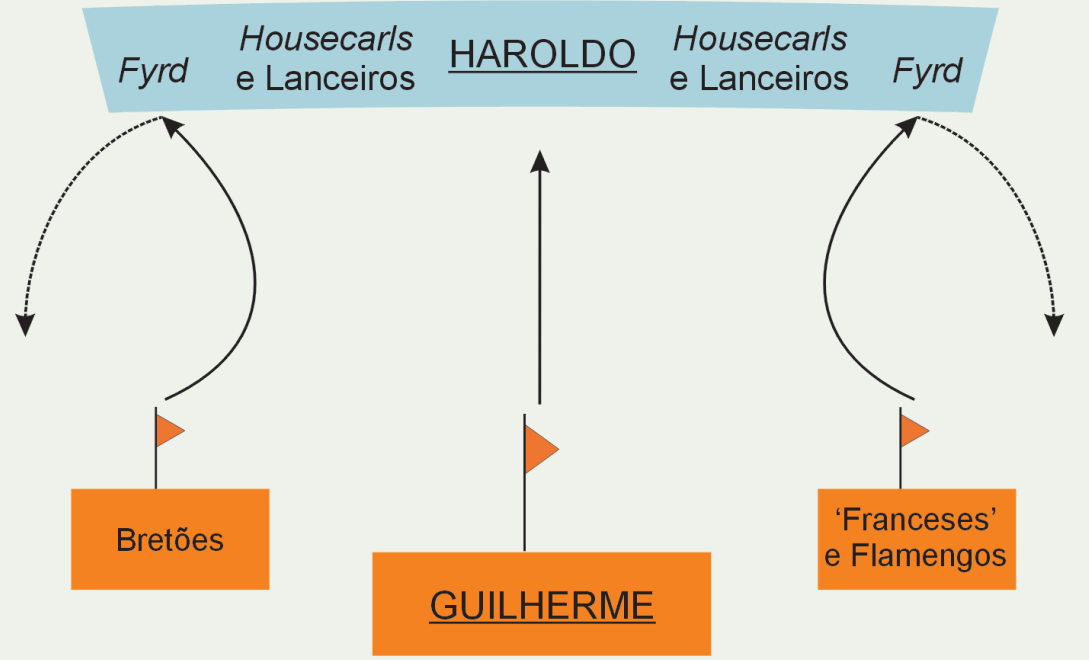

\section{Arqueiros e Besteiros}

\section{Infantaria}

\section{Arqueiros \\ e Besteiros}

Ao longo da tarde, sucedem-se as cargas intermitentes da cavalaria

Ingleses normanda. Pelo menos duas dessas cargas foram acompanhadas por manobras de fuga simulada, destinadas a atrair perseguidores incautos.

Normandos A "parede de escudos" anglo-saxónica, sem real capacidade ofensiva depois das mortes de Gyrd e de Leofwine, vai ficando debilitada. 
os seus aliados voltaram as costas, simulando deliberadamente uma fuga. Lembravam-se da oportunidade favorável que, pouco antes, a fuga lhes tinha proporcionado. Entre os bárbaros, surgiu uma imensa alegria com a esperança da vitória. Exortando-se mutuamente com um clamor exuberante, invetivavam os nossos com injúrias e ameaçavam que todos cairiam de imediato. Tal como antes tinha sucedido, alguns milhares, como se voassem, ousaram perseguir aqueles que julgavam que estavam a fugir. De repente, os Normandos, fazendo meia-volta com os seus cavalos, mataram por toda a parte os inimigos surpreendidos e cercados, não deixando nenhum vivo" (Parte II, n. ${ }^{\circ}$ 20).

De acordo com a nossa principal fonte, os Normandos usaram duas vezes este estratagema, e com sucesso, tendo depois atacado com "um entusiasmo ainda maior" os Ingleses que permaneciam fixos na sua sólida posição defensiva (Parte II, n. ${ }^{\circ}$ 21). Provavelmente, as manobras de fuga simulada terão sido protagonizadas por esquadrões autónomos (conhecidos na época por "conrois") de 15 ou 20 cavaleiros normandos atuando sincronizados, uma vez que nesta altura a arte militar ainda não tinha amadurecido o suficiente para se organizar o processo de modo a envolver as várias linhas da cavalaria pesada munida de 'lança deitada'.

No entanto, apesar das baixas sucessivas que foi possível infligir com o recurso a este método, continuava a ser "muitíssimo difícil" lidar com a parede de escudos anglo-saxónica, que Haroldo comandava a partir do centro, ladeado pelos seus housecarls e pelos lanceiros de elite. Trava-se então continua Guilherme de Poitiers - "um combate de natureza insólita, em que uma das partes avança com ataques e movimentos diferenciados e a outra resiste como que pregada ao chão. Os Anglos enfraquecem e, como que confessando a sua culpa pela derrota, sofrem o castigo. Os Normandos lançam setas, ferem, trespassam; os mortos, ao cair, parecem mover-se mais do que os vivos. Não é permitido aos feridos ligeiros escapar, uma vez que a concentração dos seus companheiros os mata por esmagamento" (Parte II, n. ${ }^{\circ}$ 21).

Aos poucos, a insistência normanda ia rendendo os seus frutos, mas o combate ameaçava eternizar-se. Estima-se que, entre as $12 \mathrm{~h}$ e as $19 \mathrm{~h}$, a colina de Senlac tenha sido palco de ataques da cavalaria e da infantaria normandas alternados com períodos de descanso e de reagrupamento. Não 
é possível quantificar estes ataques nem conceber aqueles homens combatendo ininterruptamente, com armamento pesado e, muitos deles, debaixo de indumentárias quentes e desconfortáveis: o desgaste provocado pela luta, pelos ferimentos mútuos e pela própria tensão emocional, obrigavam a intervalos regulares. Para os Ingleses, em especial para os que tinham combatido em Fulford Gate e em Stamford Bridge, muitos dos quais tinham igualmente cumprido as duas marchas forçadas organizadas por Haroldo II entre Londres e York, essas pausas devem ter sido uma bênção; todavia, ainda assim, não terão sido suficientemente retemperadoras. A frescura inicial desaparecia progressivamente e obrigava estes homens, mal dormidos e saturados de sangue, a um esforço sobre-humano; muitos ansiavam decerto pelo termo do combate, nem que fosse o cair da noite a obrigar a tanto.

Como que aproveitando a(s) pausa(s), Guilherme de Poitiers destaca a participação nesta batalha, do lado normando, de vários companheiros do duque: Eustácio, conde de Boulogne; Guilherme, filho de Ricardo, conde de Évreux; Godofredo, filho de Rotrou, conde de Mortagne; Guilherme Fitz (isto é, "filho de") Osberno; Aimeri, visconde de Thouars; Gualter Giffard; Hugo de Montfort; Rodolfo de Tosny; Hugo de Grandmesnil; Guilherme de Warenne; e muitos outros "ilustríssimos pela sua reputação de excelência militar, cujos nomes será mister louvar como entre os mais aguerridos nos livros de História” (Parte II, n. ${ }^{\circ} 22$ ). Mas, claro está, Guilherme superava-os a todos: "ele comandou os seus com distinção, travando a sua fuga, transmitindo coragem, partilhando o perigo; muito mais vezes os chamava para que o seguissem do que ordenava que fossem à frente dele. De tudo isto, percebe-se com clareza que a sua coragem na frente de combate abriu caminho aos seus soldados e incutiu-lhes audácia. Uma parte não despicienda dos inimigos perdeu o ânimo sem ter sofrido qualquer ferimento ao avistar este cavaleiro digno de admiração e terrível. Três cavalos caíram debaixo dele trespassados; três vezes ele desmontou intrépido e não deixou por muito tempo sem vingança a morte da montada. Aqui, podia-se ver a sua agilidade, ali o vigor do seu corpo e do seu espírito. Trespassou escudos, capacetes e lorigas com a sua espada furiosa e que desdenhava qualquer pausa. Com o seu escudo, arredou alguns. Ao vê-lo combater a pé, os seus cavaleiros, muitos deles cobertos de feridas, recuperaram o ânimo. 
E alguns, 'a quem o sangue e as forças já faltam’2, combatem corajosamente apoiados nos escudos; alguns, como nada mais podem fazer, instigam os companheiros com a voz e com gestos a seguir sem medo o duque e a não deixar escapar das mãos a vitória. E o próprio duque foi um auxílio e salvação para muitos" (Parte II, n. ${ }^{\circ} 22$ ).

Por volta das 19h, com a batalha ainda por vencer, Guilherme é forçado a uma investida derradeira. O duque tem consciência de que a noite está a cair e de que precisa de alcançar a vitória urgentemente. O 'empate', com efeito, servia a Haroldo, que já era rei e que 'jogava em sua casa', tendo por isso facilidade em repor os efetivos sacrificados e em reabastecer a sua hoste. O duque, pelo contrário, para derrubar o monarca, precisava de o vencer e de o matar no campo de batalha. Era isso que os seus homens esperavam dele, fora para isso que atravessara o Canal da Mancha, superando todas as dificuldades. A parada era altíssima, Guilherme queria estar à altura.

Assim, já ao crepúsculo, o duque juntou os seus arqueiros e enviou-os de novo para a linha da frente. Uma observação minuciosa do friso inferior da Tapeçaria de Bayeux permite supor que, desta feita, os atiradores levaram aljavas maiores, que em alguns casos cravaram no chão, à sua frente. Puderam, deste modo, disparar uma maior quantidade de flechas e de forma mais confortável. A análise desta parte do bordado alusivo à batalha é extremamente interessante, pois permite detetar, para esta fase do combate, a representação consecutiva de 19 arqueiros normandos, a que se seguem, quase imediatamente, outros quatro. Ou seja, 23 arqueiros normandos são mostrados em ação, uns ao pé dos outros, neste período terminal da batalha! Mas há mais: a tapeçaria sugere que, agora, muitos deles disparavam para cima, ou seja, faziam tiro mergulhante, gerando uma nuvem de flechas que depois tombava com violência sobre a primeira linha inglesa. O objetivo prioritário seria, decerto, atingir o rei e o seu núcleo duro de bousecarls, ainda agrupados em formação cerrada à volta de Haroldo e do seu estandarte com o dragão dourado do Wessex.

\footnotetext{
2 Retirado de Júlio César, De bello gallico, VII, 50: "quem iam sanguis viresque deficiunt".
} 


\section{Hastings (1066)}

Fase 5: Assalto final

\section{Tropas de Apoio}

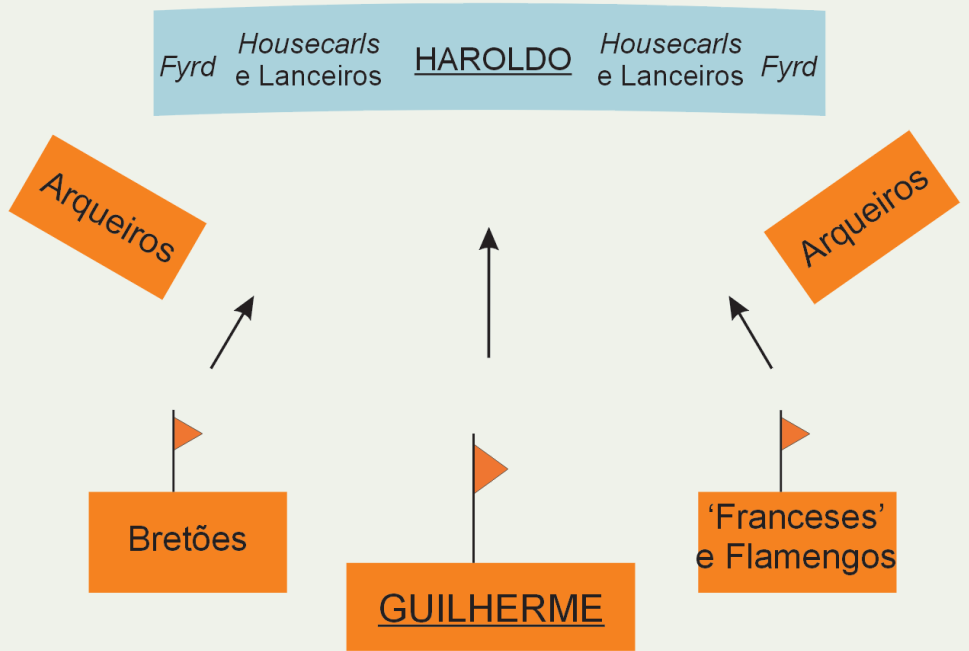

Infantaria

Já ao final da tarde, Guilherme organiza o último assalto. Os arqueiros

Ingleses

Normandos normandos avançam e fazem tiro mergulhante cerrado sobre a falange inimiga. A formação anglo-saxónica, exausta, desagrega-se cada vez mais e permite, finalmente, a carga vitoriosa da cavalaria normanda. Haroldo é abatido, assim como o seu núcleo duro e os respetivos estandartes. 
Contra tal sistema de tiro, que entrava de cima para baixo, os escudos pouco podiam fazer, a menos que fossem colocados por cima das cabeças (à maneira da "tartaruga" romana), com isso expondo perigosamente o crânio e o tronco dos melhores combatentes anglo-saxónicos e impedindo o uso das armas de duas mãos. Em complemento disto, a tapeçaria mostra, no mesmo friso inferior, como se despiam já os mortos das suas preciosas lorigas e se reuniam espadas e escudos, numa figuração de um realismo brutal, salpicada de corpos abatidos e mutilados. Depois da intervenção final dos arqueiros (e, eventualmente, dos besteiros, estes últimos fazendo tiro direto e horizontal), o caminho ficaria livre para a carga decisiva da cavalaria pesada. Com efeito, no corpo central do bordado e em linha com os 23 arqueiros do friso inferior, a tapeçaria representa a cavalaria normanda a carregar em força, num derradeiro ímpeto.

Logo a seguir, surge a cena decisiva da morte de Haroldo, atingido por uma seta num olho. Por cima desta imagem, a tapeçaria ostenta as palavras "Harold rex..." ("O Rei Haroldo..."). A legenda é completada imediatamente ao lado com as palavras "... interfectus est" ("... é morto"). Debaixo destas letras, vê-se agora um cavaleiro normando, equipado com loriga e capelina de nasal, a abater com uma espada comprida uma personagem que cai secamente no chão, como se fosse um tronco de árvore, ao mesmo tempo que deixa fugir das mãos o seu machado de cabo longo.

As opiniões dos especialistas sobre esta sequência têm-se dividido. A maior parte valoriza a primeira cena e deduz que Haroldo (tal como o rei Hardrada em Stamford Bridge) morreu vítima de uma seta, desta feita num olho (e não na garganta, como sucedera com o monarca norueguês). Mas outros autores acham que o que conta é a segunda imagem, e que o rei de Inglaterra foi abatido pela violência do choque com o cavalo normando e pelo golpe de espada aplicado pelo guerreiro que o montava, que o bordado mostra ligeiramente soerguido nos estribos e debruçado para diante, de modo a aplicar toda a sua força naquele golpe... real. Também é possível, como alguns têm aventado, que as duas cenas representem a morte de Haroldo, que assim teria sido, primeiro, atingido por um arqueiro e, depois, liquidado de vez por um cavaleiro. 


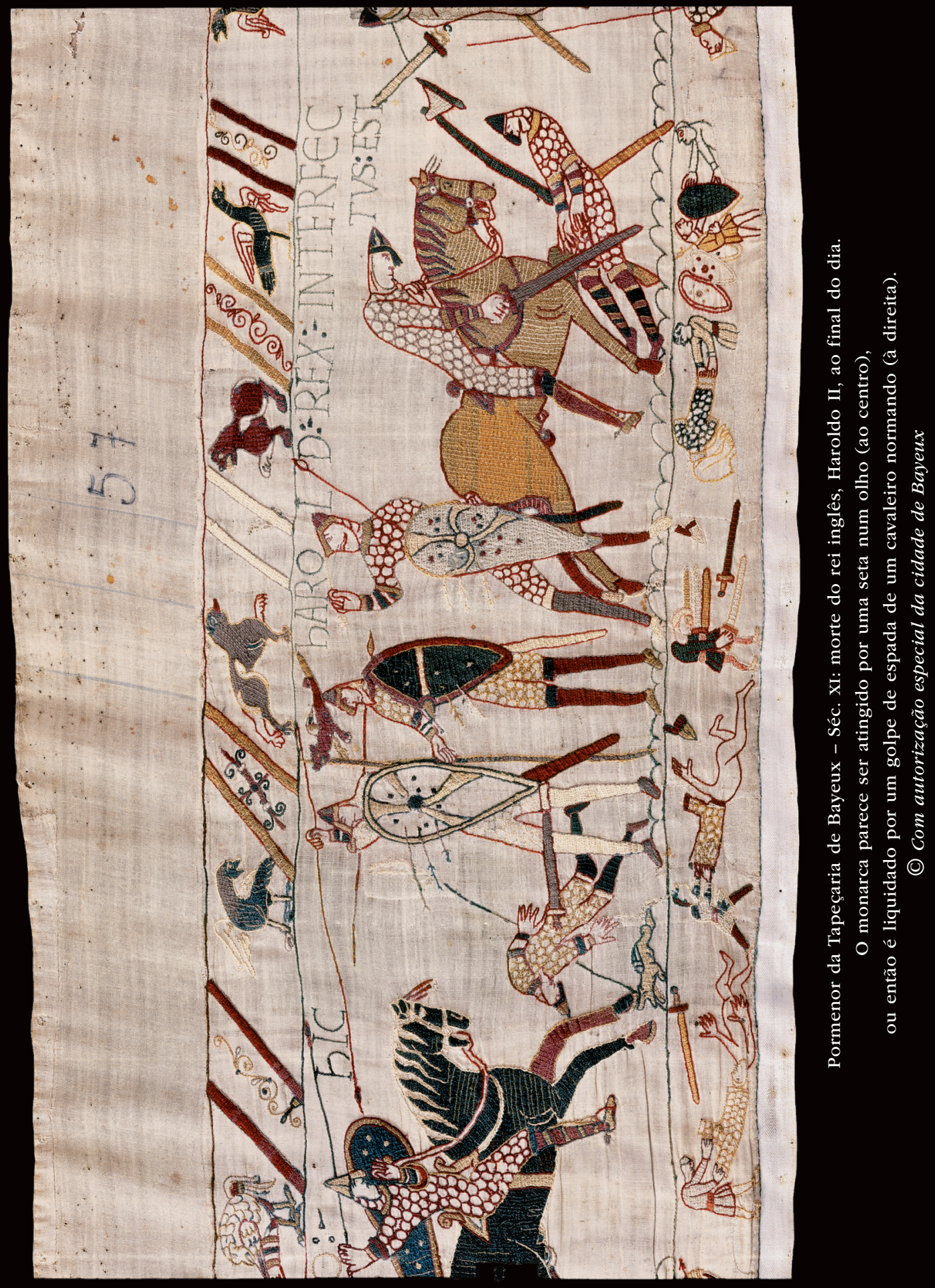


A dúvida sobre as condições exatas da morte de Haroldo II em Hastings vai persistir, uma vez que as fontes escritas não nos ajudam a resolver o caso. Guilherme de Poitiers diz apenas que o monarca de Inglaterra foi morto "ao fim do dia", juntamente com os seus irmãos e com "alguns grandes do reino", na sequência de uma ofensiva em que os Normandos se mostraram mais aguerridos do que nunca perante uma formação adversária com os efetivos já muito "enfraquecidos devido à morte de muitas tropas", e que "percebeu claramente que já não era capaz de resistir aos Normandos por muito mais tempo", pois todos os que sobreviviam "estavam com as forças quase esgotadas" e também não havia "auxílio algum que pudessem esperar" (Parte II, n. $\left.{ }^{\circ} 23\right)$.

Quanto à Crónica Anglo-Saxónica, limita-se a dizer que, apesar de Guilherme o ter apanhado de surpresa antes de ele ter o seu exército disposto em ordem de batalha, Haroldo "combateu rijamente contra ele, juntamente com os homens que estiveram dispostos a apoiá-lo [uma insinuação curiosa], tendo havido baixas pesadas de ambos os lados. Ali foi morto o rei Haroldo e o conde Leofwine, seu irmão, e o conde Gyrd, seu irmão, e muitos outros homens de valor, e os Franceses ficaram senhores do campo de batalha, ainda que Deus o tenha concedido a eles por causa dos pecados do povo" (in Morillo, p. 24).

O relato de João de Worcester é ainda mais seco, mas igualmente sugestivo: naquele sábado, ainda um terço do exército de Haroldo não estava pronto para combater, o rei travou batalha com os seus inimigos a nove milhas de Hastings [e não a sete: terá o combate tido lugar na parte mais alta da colina de Caldbec, como alguns autores, entre os quais Jim Bradbury, admitem?]; "mas, porquanto os Ingleses estavam dispostos num lugar estreito [ou seja, sem escapatória fácil], muitos abandonaram as suas fileiras e muito poucos lhe permaneceram fiéis; não obstante, desde a terceira hora do dia até ao lusco-fusco, ele [Haroldo] resistiu com bravura ao inimigo e lutou tão brava e obstinadamente em sua defesa que as forças adversárias quase não conseguiam ter efeito. Por fim, depois de uma grande matança de ambos os lados, por volta do crepúsculo o rei, ai meu Deus!, caiu. Foram também mortos o conde Gyrd e o seu irmão, o conde Leofwine, e quase toda a nobreza de Inglaterra” (in Morilllo, p. 31). 


\section{Hastings (1066)}

Fase 6: Vitória normanda

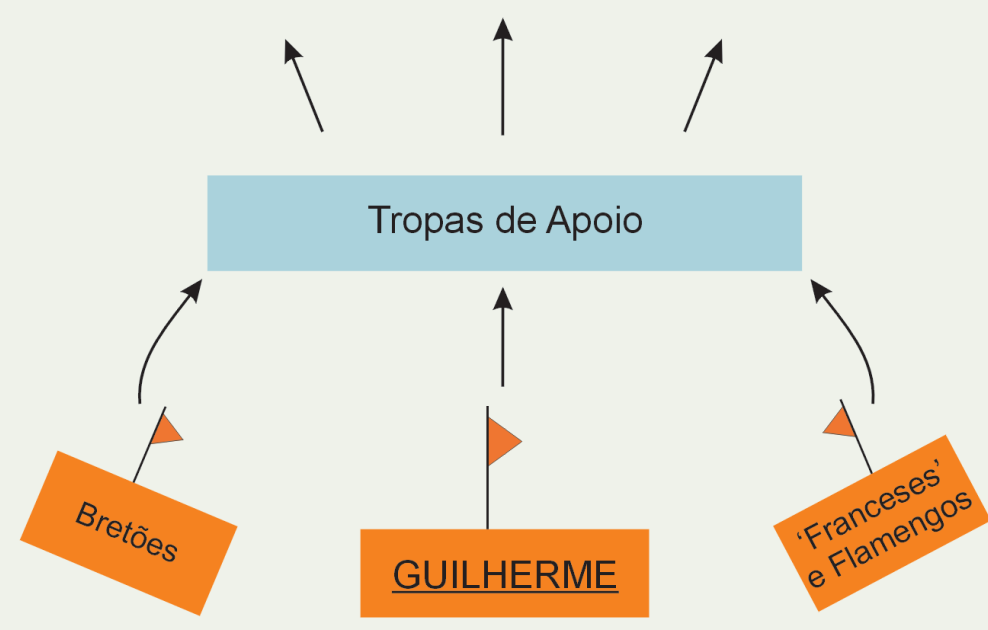

\section{Arqueiros}

e Besteiros

\section{Infantaria}

\section{Arqueiros}

e Besteiros

Destroçada a linha principal e morto o rei e os seus irmãos, as tropas de

\section{Ingleses}

Normandos apoio inglesas, depois de uma última resistência (na esperança do cair da noite), lançam-se em fuga. A cavalaria normanda persegue-as durante algum tempo e, depois, regressa ao campo de batalha. Guilherme vencera o combate! 
Pelo seu lado, Guilherme de Jumièges, depois de lembrar que "a batalha começou à terceira hora do dia e continuou por entre um rebuliço de carnificina e matança até ao cair da noite", escreve que "o próprio Haroldo, combatendo no meio da linha da frente do seu exército, caiu coberto de feridas" (in Morilllo, p. 18).

No meio deste laconismo, o relato do Carmen sobre o final da batalha parece mais extravagante ainda. Diz o poeta, eventualmente o bispo Guido de Amiens, que Guilherme, com a batalha já quase ganha, avistou Haroldo lá ao longe liquidando todos os Normandos que o cercavam. Então, o duque chamou Eustácio de Boulogne, Hugo de Ponthieu e Gualter Giffard e, os quatro, foram atacar o rei inglês: um perfurou-lhe o peito com uma espada, outro cortou-lhe a cabeça por debaixo da proteção do capacete, o terceiro furou-lhe a barriga com uma lança e, por fim, o quarto arrancou-lhe uma coxa e foi-se embora com o membro amputado... Uma execução macabra, digna de um filme policial!

Seguiu-se a debandada geral dos Ingleses, logo que correu o rumor da morte do rei (Carmen), e tal como a tapeçaria regista na última cena de que hoje dispomos. Os Normandos, inebriados pelo sucesso, iniciaram uma perseguição brutal, verdadeira descarga de ódios e de medos. Escreve Guilherme de Poitiers que os sobreviventes do exército real inglês, voltando as costas, "puseram-se em fuga o mais rapidamente possível, uns em cavalos a que deitaram a mão, outros a pé; uma parte, pelas estradas, outra, por lugares ermos. Alguns que se esforçavam por fugir jaziam em sangue, outros estavam em pé mas não tinham forças para isso. A enorme vontade de se salvarem transformou alguns em valentes. Muitos acabaram cadáveres em florestas recônditas e muitos, caídos ao longo dos caminhos, foram um obstáculo para os que vinham atrás”. Apesar de não conhecerem a região, os Normandos perseguiram sem descanso, "golpeando-lhes as costas culpadas e consumando a vitória. E até os cascos dos cavalos infligiam punições aos mortos enquanto galopavam por cima dos que estavam caídos" (Parte II, n. ${ }^{\circ} 23$ )!

Podemos imaginar este cenário terrível, com os Ingleses que sobreviveram a implorar misericórdia, fugindo da morte e tentando aproveitar a escuridão, as moitas e os abrigos da densa floresta para escapar ao destino 
(Carmen). A Tapeçaria de Bayeux mostra alguma tropa do fyrd, sumariamente equipada (sem lorigas nem capelinas, vários com uma maça de armas), a fugir, uns a pé e outros a cavalo, um dos quais parecendo querer arrancar uma seta que trazia espetada na testa... Na sua peugada, vê-se um grupo de cinco cavaleiros normandos, três deles brandindo uma espada, outro uma lança e o último disparando um arco enquanto cavalga. Por cima, uma legenda óbvia: "et fuga verterunt Angli" ("e os Ingleses puseram-se em fuga"). Stephen Morillo estima que esta perseguição se tenha prolongado entre as $20 \mathrm{~h}$ e as $21 \mathrm{~h}$, tendo sido interrompida pelo cair da noite cerrada, que desaconselhava que se corressem mais riscos, para mais em território estranho.

Entretanto, há ainda um último episódio a assinalar, o chamado "episódio Malfosse", que tanta tinta tem feito correr. Como notou R. Allen Brown, trata-se de um incidente menor, sem qualquer influência no resultado final da batalha; ainda assim, vale a pena recordá-lo. Guilherme de Poitiers conta que, durante a fuga, alguns Ingleses "encontraram uma excelente oportunidade para regressar ao combate proporcionada por uma trincheira escarpada e por numerosos fossos" ("praerupti ualli et frequentium fossarum") e, como os Saxões são um povo que "sempre foi inclinado a pegar em armas", sacaram das espadas e tentaram relançar a batalha, tanto mais que se encontravam moralizados pelo êxito recente averbado em Stamford Bridge. O duque, quando viu que as tropas se tinham aglutinado inesperadamente, cuidou que se tratava de reforços ingleses; destemido, continuou a avançar naquela direção, apesar de já trazer a sua lança quebrada; com a sua "potente voz", ordenou a Eustácio de Boulogne, que tinha virado costas com mais uns 50 cavaleiros e que queria "fazer soar o sinal de retirada", que não se afastasse. Eustácio, porém, "falando com intimidade ao ouvido do duque", aconselhou Guilherme a retirar e até predisse que este seria rapidamente abatido caso persistisse em avançar; todavia, quando proferia estas palavras, foi ele próprio atingido por um violento golpe entre as espáduas, que lhe fez jorrar de imediato sangue pelo nariz e pela boca; meio-morto, acabou por escapar com a ajuda dos seus companheiros. Quanto a Guilherme, avançou contra os inimigos e venceu-os, apesar de alguns dos mais ilustres normandos terem caído neste combate, uma vez que a sua coragem "foi inútil devido à desvantagem do terreno" (Parte II, n. $\left.{ }^{\circ} 24\right)$. 
Uma história semelhante (sem referências a Eustácio) surge também noutras fontes, embora com algumas muances. Orderico Vital, nas Interpolações a Guilherme de Jumièges, explica que a erva alta escondeu uma antiga trincheira ("antiquum aggerem") e que os Normandos cavalgaram para ali e caíram uns por cima dos outros. A 'versão completa' deste episódio surgiria apenas na Historia Ecclesiastica de Orderico, em cujo livro III (terminado em 1120 e onde o relato segue, em geral, de perto o da Gesta Guillelmi) o autor combina de forma desajeitada a passagem de Guilherme de Poitiers com a sua própria versão nas Interpolações a Jumièges: afirma Vital que os perseguidores normandos cavalgam até um "antiquum aggerem"; encorajados pelo terreno, e também por um "praeruptum uallum" e por um labirinto de valas, os Ingleses fazem frente e infligem baixas pesadas (citado por R. Allen Brown, in Morillo, pp. 215-216).

Com a Crónica da Abadia de Battle, em meados do séc. XII, surge, finalmente, o nome "Malfosse". A crónica diz que "um derradeiro desastre revelou-se aos olhos de todos: mesmo ali onde a batalha estava a decorrer, e espalhando-se por uma distância considerável, abria-se uma imensa vala"3; escondida por arbustos espinhosos e por cardos, engoliu muitos homens, em especial Normandos que perseguiam, "pois quando, todos eles desconhecendo o facto, chegaram ali a galope, o seu ímpeto terrífico levou-os diretamente para dentro dela, e morreram tragicamente, feitos em pedaços". O cronista diz mesmo que o local do desastre (agora designado por "cova grande") era chamado, nos seus dias, de "Malfosse". Mas, infelizmente, não identifica o local.

Num outro conjunto de versões da batalha, o episódio ocorre durante o combate. Guilherme de Malmesbury fala num fosso escarpado ("fossatum quoddam praeruptum"), com o qual os Ingleses estariam familiarizados e onde liquidaram muitos dos seus adversários - tantos que a pilha de cadáveres encheu a concavidade. Também Henrique de Huntingdon coloca o episódio Malfosse no meio da batalha e como parte da fuga simulada, durante a qual os Normandos cavalgaram para uma grande vala escondida ("quondam foveam magnam dolose protectam"). O mesmo faz Wace, para

\footnotetext{
3 Traduzido por nós a partir de R. Allen Brown, in Stephen Morillo, 1996, p. 216.
} 
quem o desastre tem lugar durante a fuga real dos Normandos, afirmando que o fosso foi mandado escavar por Haroldo antes da batalha (citados por R. Allen Brown, in Morillo, p. 217). Nem o Carmen nem Baudry de Bourgueil referem o "episódio Malfosse".

Assim, como sintetiza Allen Brown, há dois tipos de versão sobre este episódio (durante e depois da batalha) e não há maneira de escolher entre eles. Entretanto, segundo Jim Bradbury, o "Malfosse" já foi identificado: está situado cerca de $580 \mathrm{~m}$ a norte da colina de Caldbec e trata-se de um obstáculo natural, uma ravina profunda com margens íngremes, arbustos, vegetação rasteira e uma linha de água, conhecido por "Oakwood Gill” ("oakwood" significa "floresta de carvalho", e "gill" quer dizer "vale estreito e profundo"). Bradbury admite que o obstáculo pudesse integrar um plano inglês para cobrir a retirada, em caso de necessidade, mas não temos elementos suficientes para dizer mais do que isto. Limitar-nos-emos a sublinhar como é curioso o contraste entre a forma como Guilherme de Poitiers retrata Eustácio de Boulogne (apresentado como um cobarde) e os louvores que lhe dedicam o Carmen e a própria Tapeçaria de Bayeux, que lhe atribuem um papel de liderança, ao lado do duque normando. No Carmen, Eustácio chega mesmo a oferecer o seu cavalo a Guilherme, quando a montada do duque é abatida; na tapeçaria, Eustácio é um dos raros cavaleiros identificados pelo nome. Provavelmente, a discrepância terá que ver com o momento da composição das narrativas: é que Eustácio de Boulogne (que, recordamos, era cunhado de Eduardo "o Confessor" e o visitou em Inglaterra em 1051, provocando o incidente que conduziu ao exílio dos Godwin) acabaria por cair em desgraça junto de Guilherme, ao promover uma revolta em Dover. Mais tarde, foi perdoado e reconciliou-se com o novo rei de Inglaterra, Guilherme "o Conquistador", mas é possível que o relato de Poitiers tenha sido escrito pouco depois da revolta de Dover, ao passo que a tapeçaria foi seguramente elaborada depois da reconciliação, enquanto o Carmen terá sido composto, ou antes do episódio de Dover, ou muito depois da reabilitação deste duvidoso aliado de Guilherme.

Regressados, altas horas da noite, ao campo de batalha, após a breve mas feroz perseguição, o duque e os seus ocuparam formalmente o terreno - o sinal tradicional de vitória nos combates da Idade Média. Descansaram, 
trataram os feridos e, quando o Sol voltou a nascer, procederam à identificação dos mortos: podemos admitir cerca de 30\% de baixas do lado normando e substancialmente mais entre o exército anglo-saxónico.

Segundo Guilherme de Poitiers, "a flor da nobreza e da juventude dos Anglos, manchada de sangue, cobria uma grande extensão do terreno" (Parte II, n. ${ }^{\circ}$ 25). Os corpos de Gyrd e de Leofwine foram encontrados perto do de Haroldo, mas este teve de ser identificado por certas marcas pessoais, de tão irreconhecível que estava. A mãe de Haroldo, Gyda, que perdera quatro filhos em vinte dias (Tostig em Stamford Bridge; Gyrd, Leofwine e Haroldo em Hastings), tentou recuperar o corpo do rei e ofereceu mesmo o peso deste em ouro, mas Guilherme recusou: seria indigno aceitar uma tal oferta e, além disso, considerava injusto sepultar Haroldo da forma que a mãe desejava, quando uma quantidade imensa de corpos de soldados jazia insepulta no campo de batalha, tudo por causa da imensa cupidez do falecido monarca; segundo Poitiers, Guilherme entregou o corpo de Haroldo a um tal Malet, que se encarregou do enterro. O duque não desejava promover nenhum mártir e terá dito, em jeito de gracejo, que o melhor seria sepultar Haroldo junto da costa, uma vez que a sua loucura o tinha levado a tornar-se, com os seus exércitos, o guardião do litoral e do mar [eis uma ironia que sugere as preocupações causadas à invasão normanda pela presença, durante todo o verão, do exército real inglês na zona sul de Inglaterra].

O Carmen confirma, no essencial, esta versão dizendo que, ao amanhecer, Guilherme sepultou os seus e deixou os corpos dos Ingleses entregues aos vermes, aos lobos, às aves e aos cães; quanto ao corpo do rei, foi embrulhado em linho fino de púrpura e levado para o acampamento, onde o duque se recusou a entregá-lo à mãe: Guilherme mandou sepultar o seu rival na costa, no cimo de um rochedo, debaixo de uma pilha de pedras; o serviço terá sido feito por um companheiro de Haroldo, meio inglês e meio normando [provavelmente o tal Malet], que gravou o seguinte epitáfio: "Por mandado do duque, Ó Haroldo, descansa aqui como um rei / Para que possas continuar a ser o guardião da costa e do mar" (in Morillo, pp. 51-52).

Entretanto, Jim Bradbury refere que um monge de 1177, com base na tradição, disse mais tarde que o corpo do rei foi recuperado e enterrado 
na abadia de Santa Cruz de Waltham (no Essex), de que o próprio Haroldo fora o benfeitor. Curiosamente, Wace, no Roman de Rou (segunda metade do séc. XII), diz que o abade do mosteiro de Waltham enviou dois monges, Osgod e Ailrik, para recuperar o corpo de Haroldo; estes não conseguiram identificá-lo e recorreram à amante do rei, Edite "colo de cisne", que o conseguiu fazer. Philip Morgan, que reviu muito recentemente o estudo da batalha, aceita a ideia da sepultura na abadia de Waltham e acrescenta um comentário interessante: a forma como Haroldo morreu pode não ter sido conhecida de imediato e deve ter sido extrapolada posteriormente, a partir dos ferimentos descobertos no seu corpo; segundo este autor, Haroldo pode ter sido ferido por uma seta na cabeça e mutilado só quando o seu séquito cedeu, no último assalto; se o artista da tapeçaria [ou alguém por ele, num acrescento tardio] adotou a 'flecha no olho' como causa da morte do rei, foi certamente por causa do seu significado alegórico - para salientar a ideia da punição do perjúrio.

Morto e enterrado o monarca - um facto que praticamente decidiu a guerra -, impõe-se tentar fazer um balanço do combate e identificar as principais causas da vitória dos Normandos. Antes de mais, devemos salientar que a batalha foi, como observou Stephen Morillo, bastante invulgar por três razões principais. Primeiro, porque foi extremamente longa: terá durado nove ou dez horas, o que é relativamente invulgar para o padrão médio do mundo medieval e também do mundo antigo, onde os combates não costumavam durar muito mais de duas ou três horas. Em segundo lugar, porque foi uma batalha muito renhida e, exatamente por isso, extremamente longa. Este facto mostra que nenhuma das partes dispunha de uma vantagem decisiva sobre a outra e que a liderança de ambos os exércitos era de boa qualidade. Portanto, a ideia tradicional de que Hastings constituiu uma vitória inevitável da cavalaria com estribo e lança sobre uma infantaria obsoleta e desamparada não pode merecer a nossa concordância; se assim fosse, a batalha teria terminado muito mais cedo e os Normandos não teriam estado à beira do colapso. Ora, em Hastings, os dois líderes apostaram (muito) forte e tinham boas razões para isso. Em terceiro lugar, Hastings foi uma batalha decisiva, na medida em que poucas batalhas na história da Europa 
transferiram o poder de um povo para outro. Hastings, só por si, decidiu realmente uma guerra, tal como acontecera em Zama, em 202 a. C. (vitória de Cipião Africano sobre Aníbal Barca, no final da Segunda Guerra Púnica), e como viria a suceder em Waterloo, em 1815 (vitória de Wellington e de Van Blücher da Prússia sobre Napoleão Bonaparte). No entanto, o que sobressai de mais extraordinário em Hastings são as suas consequências a longo prazo: na sequência desta batalha e devido a ela, a Inglaterra entrou num novo patamar histórico, com ramificações numa vasta área do mundo; a síntese que resultou de Hastings não teria tido lugar sem a batalha. Nesse sentido, Hastings quase só pode ser comparada a Gaugamela (vitória de Alexandre Magno sobre Dario III Codomano da Pérsia, em 331 a. C.), a primeira grande batalha que analisámos neste livro.

Mas por que razão é que, neste combate tão renhido, foi Guilherme o vencedor, e não Haroldo? Sugerimos seis fatores que, não sendo os únicos, ajudam a construir uma resposta sensata a esta questão:

1. A composição do exército normando, que, embora provavelmente menos numeroso, era muito mais eclético e mais completo do que o anglo-saxónico: tinha infantaria, arqueiros e excelente cavalaria. Do outro lado, Haroldo II de Inglaterra só contava com infantaria e cavalaria (do fyrd) desmontada, apesar de muito boa qualidade e enquadradas pelos famosos housecarls; arqueiros, do lado inglês, deve ter havido muito poucos, e bem falta fizeram.

2. ${ }^{\circ}$ A superioridade do comando normando: Guilherme, ao travar a debandada das suas tropas numa fase ainda precoce da batalha (quando correu o rumor da sua morte), evitou a débâcle. Além disso, liderou sempre os seus homens de muito perto, lutou ao lado deles (apesar de ter visto os seus cavalos abatidos por duas ou três vezes) e teve a paciência necessária para realizar o derradeiro assalto (com cavalaria e arqueiros) na altura ideal, quando a "parede de escudos" inglesa já estava bastante debilitada. Quanto a Haroldo, para além de ter iniciado a marcha para o campo de batalha com o seu exército ainda muito incompleto, falhou a sua (provável) estratégia de apanhar o adversário de surpresa no acampamento 
de Hastings e falhou também a sua grande oportunidade para um contra-ataque bem-sucedido - por ocasião da primeira fuga (neste caso real) da linha de cavalaria normanda.

3. A morte prematura dos irmãos de Haroldo II, Gyrd e Leofwine, possivelmente durante a primeira perseguição anglo-saxónica à cavalaria normanda (em processo de fuga real). Isto privou o rei inglês de dois comandantes fundamentais para que a "parede de escudos" anglo-saxónica pudesse ter, não apenas uma dimensão defensiva, mas também a expetativa de aproveitar o momento certo para contra-atacar com êxito.

4. ${ }^{\circ}$ O estado de cansaço do exército inglês (ao contrário do seu rival): o núcleo duro da hoste comandada por Haroldo II deve ter percorrido, entre 17 de setembro e 14 de outubro de 1066, uma distância total de perto de $700 \mathrm{~km}$ em regime de marcha forçada, para além de ter travado no dia 25 de setembro, em Stamford Bridge, uma batalha bastante violenta contra o rei norueguês Harald Hardrada e o seu aliado Tostig Godwinson (o irmão desavindo de Haroldo). Esta menor frescura física deve ter-se feito sentir com especial intensidade na segunda parte da batalha e pode também ter-se traduzido num menor controlo emocional, designadamente para resistir às manobras de fuga simulada executadas pela cavalaria normanda.

5. ${ }^{\circ}$ O sucesso dessas manobras (possivelmente duas) de fuga simulada realizadas pelos Normandos, que terão atraído alguns milhares de Ingleses para fora da sua forte posição defensiva, que assim foi ficando substancialmente enfraquecida. E ingloriamente, porque os perseguidores ingleses acabaram sempre chacinados às mãos dos seus adversários...

6. A morte de Haroldo II, numa fase já bastante adiantada da luta, facto que liquidou de vez as esperanças de resistência inglesa, galvanizou o exército normando e precipitou o fim da batalha, a perseguição (embora curta, devido ao cair da noite) e a inevitável chacina. 
Hoje, o campo de batalha de Hastings é uma superfície bem preservada e que guarda dignamente a memória desta importantíssima batalha. Ali foram construídos, por ordem de Guilherme, os belos edifícios da abadia de Battle, coroando a colina de Senlac; Mogens Rud explica que o duque ordenou de imediato a construção do mosteiro, consagrando-o à Santíssima Trindade e instalando lá monges vindos de Marmoutier (na Alsácia, a $30 \mathrm{~km}$ de Estrasburgo); Guilherme fez questão de edificar o altar-mor no local do posto de comando de Haroldo - o sítio provável da morte do rei inglês. Segundo o Chronicon monasterii de Bello, que data do séc. XII, o duque quis que o local passasse a chamar-se "Battle" para que o seu sucesso fosse recordado para sempre. A "venerável macieira" há muito que desapareceu e o próprio nome de "Senlac" depressa foi superado pela designação oficial de "Hastings". Espólio relevante da batalha, apesar das investigações arqueológicas realizadas, não foi encontrado: a terra e a cobiça dos homens tudo devoraram ao longo dos séculos. Porém, ficou o mais importante: a memória escrita e visual deste facto extraordinário, que alterou profundamente a história da Inglaterra, da França e, por arrastamento, de uma grande parte do Ocidente europeu.

\section{O 'dia seguinte'}

No dia 15 de outubro, Guilherme e o seu exército abandonaram o campo de batalha e regressaram a Hastings. Diz a Crónica Anglo-Saxónica que o duque "esperou aí para ver se haveria submissões a ele" (in Morillo, p. 24). Como isso não sucedeu, Guilherme deixou Humphrey de Tilleul a chefiar a guarnição e rumou a leste, numa curta expedição punitiva contra os habitantes de Romney, que haviam tomado os dois barcos normandos que, no dia da travessia da Mancha, tinham aportado demasiado a leste de Pevensey (Orderico Vital explica que acamparam ali por engano). Na altura, as forças normandas tinham sido massacradas e Guilherme fez questão de ajustar contas com os locais.

A seguir, o duque encaminhou-se para Dover, a porta de entrada em Inglaterra. A cidade rendeu-se sem resistir, mas a guarnição parece ter 
demorado algum tempo a decidir-se, pelo que alguns Normandos, sem autorização de Guilherme, começaram a deitar fogo às fortificações. O incêndio propagou-se a muitas casas e enfureceu o duque, que obrigou os desobedientes a pagar as respetivas reparações às vítimas: era um primeiro exemplo da disciplina que Guilherme desejava ver implantada em Inglaterra.

Em Dover, o exército normando foi assolado por uma crise de disenteria, resultado provável da ingestão de muita carne fresca e de água imprópria para beber. Orderico diz que a tragédia causou muitas mortes e que muitos dos pacientes que sobreviveram acusaram os efeitos da doença pelo resto das suas vidas. Ultrapassado o problema, os Normandos tomaram a estrada romana que seguia na direção de Canterbury - um dos maiores centros religiosos de Inglaterra e uma peça vital para o controlo de toda a região do Kent. Antes de chegarem a Canterbury, veio até eles uma delegação de cidadãos, com reféns e juras de fidelidade. A ocupação fez-se, portanto, sem dificuldade, mas foi justamente em Canterbury que surgiu um problema que por pouco não pôs em causa todo o projeto normando e a própria vitória de Hastings: Guilherme adoeceu gravemente, talvez também de disenteria, e esteve às portas da morte; durante um mês, tudo ficou em suspenso, mas o duque era rijo e conseguiu recuperar. Ainda no leito, exigiu de Edite (a viúva de Eduardo "o Confessor" e irmã de Haroldo II) que lhe entregasse o importantíssimo castelo de Winchester, no Hampshire, que ela recebera como dote de viúva. Cumprido o desejo do duque, a cidade rendeu-se.

Guilherme definiu então como objetivo seguinte a tomada de Londres. Para o efeito, desenvolveu aquilo que Stephen Morillo considerou ser uma devastadora aproximação leste-oeste, em círculos, até à capital de Inglaterra. Esta aproximação sucessiva tinha a sua lógica, pois o avanço direto sobre Londres era um projeto arriscado; aliás, uma força londrina, com cerca de 500 cavaleiros, saiu ao caminho dos Normandos, mas foi desbaratada, tendo os invasores deitado fogo à parte sul da cidade, posto o que se retiraram. Orderico refere que havia um grande luto em Londres, o que confirma a ideia de um elevado número de combatentes da cidade ter estado presente em Hastings, ao lado de Haroldo II.

Mas havia mais: Londres tornara-se a anfitriã de um meeting de oposicionistas a Guilherme, que procuravam desesperadamente uma alternativa 
para rei de Inglaterra. O arcebispo de Canterbury, Stigand, encabeçava a 'oposição', que incluía também o conde da Nortúmbria (Morcar), o conde da Mércia (Edwin, irmão do anterior), Edgar "Etheling" e muitos outros. O monge de Worcester explica que, ao saberem da morte de Haroldo II em Hastings, os condes Edwin e Morcar partiram para Londres e enviaram a rainha Edite para Chester; o arcebispo de York (Eadred), aqueles dois condes e muitos burgueses e marinheiros de Londres promoveram então a candidatura de Edgar, neto, como sabemos, do rei Edmundo Ironside (1016), o rival de Cnut "o Grande". Contudo, o projeto não correu bem, não sabemos exatamente porquê: diz a Crónica Anglo-Saxónica que Edwin e Morcar prometeram apoiar este movimento, "mas quanto mais isto devia andar para diante, mais andou para trás, e pior isto ficou de dia para dia, tal qual tudo acabou por ficar no final" (in Morillo, p. 24). João de Worcester é mais pragmático e explica que estava tudo a postos para a luta e que os apoios de Edwin e de Morcar pareciam seguros, "mas, quando muitos se preparavam para sair para combater, os condes retiraram o seu apoio e regressaram a casa com os seus exércitos" (in Morillo, p. 31)...

As divisões e hesitações no seio da oposição facilitaram a vida a Guilherme, que, depois de devastar o Sussex, o Kent, o Middlessex e o Herefordshire, queimando casas e matando habitantes, avançou na direção do Tamisa, atravessou o rio e alcançou o burgo de Wallingford, onde Stigand veio submeter-se. Animado, Guilherme marchou resolutamente sobre Londres, mas os cidadãos decidiram sair ao seu encontro e submeter-se também. Deu-se então uma reunião em Berkhamsted (a noroeste de Londres), onde Eadred de York, o bispo Wulfstan de Worcester, o bispo Gualter de Hereford, Edgar Etheling (que o duque parece ter acolhido como se fosse um filho), Edwin da Mércia, Morcar da Nortúmbria, os homens mais notáveis de Londres e muitos outros juraram fidelidade ao duque e celebraram um pacto com ele, tendo havido igualmente lugar à entrega de reféns. Comenta a Crónica Anglo-Saxónica, acerca desta rendição oposicionista, que "foi uma loucura não o terem feito mais cedo, pois Deus não faria as coisas melhor, por causa dos nossos pecados".

O pacto não parece ter travado as pilhagens dos Normandos, que então se sentiram com força suficiente para avançar para a coroação do seu duque. 
Com profundo simbolismo, a cerimónia da consagração de Guilherme teve lugar no dia de Natal de 1066, na igreja do Apóstolo São Pedro (a futura abadia de Westminster). Guilherme de Poitiers diz que o duque hesitou em ser rei, tendo sido preciso os Ingleses insistirem (pois estavam habituados a ser governados por um monarca), assim como alguns Normandos mais próximos, entre os quais Aimeri de Thouars, considerado pessoa muito influente. Guilherme terá aceitado pensando que, depois de coroado, talvez o povo acalmasse e pensasse duas vezes antes de se revoltar.

A cerimónia, em que se verificou a introdução pelos Normandos do ritual da aclamação, foi conduzida pelo arcebispo de York e pelo bispo de Coutances. Eadred perguntou aos Ingleses, na língua destes, se concordavam com a entronização de Guilherme, ao que eles responderam que sim, com um clamor tal que os guardas normandos que vigiavam a entrada e os arredores da igreja se assustaram e, receando algo, começaram a deitar fogo aos subúrbios... Seguiu-se a mesma pergunta, mas agora feita pelo bispo de Coutances e em língua francesa, ao que os Normandos responderam de igual forma. A divisão (linguística) das elites fica aqui bem à vista: era uma nova Inglaterra que nascia e a convergência destas duas partes iria demorar o seu tempo.

Diz-se que Guilherme tremia durante a cerimónia, talvez de emoção e sentindo a responsabilidade daquele momento, que era decisivo para o seu futuro político. Poitiers justifica-o, explicando que Guilherme era o herdeiro legal da coroa, os Ingleses tinham-no confirmado por juramento, ele tinha entrado pelo combate na posse da sua herança, fora coroado com o consentimento dos Ingleses (ou, pelo menos, segundo o desejo dos respetivos senhores) e, ainda por cima, tinha laços de sangue com Eduardo. Portanto, não havia por onde contestar a cerimónia. Nela, diz João de Worcester que o rei Guilherme I de Inglaterra prometeu defender as igrejas e os padres, fazer justiça, praticar o bem, respeitar a lei, interditar as pilhagens e travar as sentenças injustas. A Crónica Anglo-Saxónica também recorda as boas promessas, mas acrescenta que, logo a seguir, o novo rei tratou de lançar pesadas taxas sobre a população (e, de facto, temos notícia da cobrança de um "geld" logo em 1066, para pagar ao exército normando). 
Guilherme tratou então de recompensar os seus principais apoiantes (havia muitas terras desocupadas que o permitiam fazer facilmente) e de enviar prendas sumptuosas para a Normandia e para o papa. Tomou algumas medidas apaziguadoras, procurando reduzir o número de crimes, limitar o consumo do vinho e repor a ordem pública; também perdoou aos condes do Norte, Edwin e Morcar, e confirmou os bens daqueles que se lhe submeteram voluntariamente.

Como seria de esperar, o novo monarca dedicou uma atenção especial à defesa do sul de Inglaterra, em particular a Dover, Hastings e Pevensey, cujas fortificações foram reforçadas. A maioria dos Normandos ficou em Inglaterra para consolidar a conquista; muitos foram utilizados para garantir a fidelidade dos portos do sul, de modo a preservar as comunicações com a Normandia; encontramos fiéis de Guilherme no Sussex, no Kent e no Hampshire (zona de Winchester-Southampton). Foi mais fácil controlar o sul porque a nobreza desta região de Inglaterra tinha, em grande parte, sido dizimada na batalha de Hastings. Odão, bispo de Bayeux e meio-irmão do rei, recebeu o castelo de Dover e o condado de Kent; Guilherme Fitz Osbern ficou responsável pela Ilha de Wight, tendo-se instalado em Winchester, onde existiu um castelo a partir de 1067; Roberto, conde de Mortain e também ele meio-irmão do novo rei, ficou com Pevensey, e Guilherme Warenne com Lewes.

Tomadas estas providências, em março de 1067, Guilherme "o Conquistador" dirigiu-se para Pevensey e regressou à Normandia. A bordo, porém, levava, não apenas muitos dos seus apoiantes, mas também muitos 'reféns políticos' - gente de lealdade duvidosa e que Guilherme não queria deixar em roda livre na Inglaterra: Edgar Etheling, Stigand, Edwin, Morcar, o conde Waltheof (filho do ex-conde da Nortúmbria, o dinamarquês Siward), o abade de Glastonbury e outros notáveis de Inglaterra. Odão e Fitz Osbern ficaram a governar a Inglaterra em nome do rei, e diz a Crónica Anglo-Saxónica que houve então "castelos espalhados por todo o reino" e que eles "atormentaram o povo miserável", pelo que, "depois disto, tudo correu sempre muito pior" (in Morillo, p. 26).

Na Normandia, "o Conquistador" deve ter tido uma receção apoteótica: temos notícia de grandes festejos, em especial em Rouen, a capital do 
principado; Matilde da Flandres, a esposa do duque, preparara quatro belas tapeçarias, que documentam o grande orgulho pelo feito dos Normandos liderados por Guilherme; o próprio sogro do rei de França, Filipe I, veio felicitar o herói. Consta que as gentes da Normandia se mostraram muito impressionadas com os 'reféns' que acompanhavam o novo monarca, em particular com as suas longas cabeleiras e com os seus tecidos ricamente bordados com a filigrana anglo-saxónica. No entanto, o vencedor de Hastings ainda não podia dormir descansado: no continente, os movimentos do conde de Anjou, do conde de Flandres e do próprio rei de França exigiam uma vigilância permanente.

Deste modo, Guilherme viu-se obrigado a dividir o seu tempo entre a Inglaterra e a Normandia. A rainha Matilde foi coroada em Inglaterra logo no dia de Pentecostes de 1067; quanto ao rei, regressaria apenas a 6 de dezembro desse ano (nove meses depois da viagem à Normandia) para completar a sua conquista. O clima era de revolta latente, com mensageiros da 'oposição' a serem enviados à Dinamarca e a outros lugares, procurando federar a resistência ao homem que vencera em Hastings. Guilherme depressa percebeu que teria de endurecer a sua política e mandou construir castelos em todos os lugares estratégicos de Inglaterra. Foi, aliás, nesta altura que teve início a construção da Torre de Londres, com a célebre "pedra de Caen" - uma pedra de cor cinzento-amarelada, muito característica. Os próximos anos iriam ser assaz difíceis para "o Conquistador".

\section{Os anos da revolta inglesa}

O primeiro problema sério com que os Normandos se confrontaram após a conquista foi a já referida revolta de Eustácio de Boulogne. Não conhecemos a data precisa do evento, que consistiu num ataque ao castelo de Dover, na ausência de Odão de Bayeux e de Hugo de Montfort. A operação fracassou devido à resistência da guarnição, mas saldou-se numa grande matança, com muitas das vítimas a sucumbirem por afogamento. Eustácio conseguiu fugir, mas mais tarde reconciliar-se-ia com Guilherme. 
Em março de 1067, mês em que o novo rei regressou à Normandia, eclodiu um problema grave no Norte. Copsi, o ex-tenente de Tostig, que Guilherme nomeara como novo conde da Nortúmbria (talvez para homenagear o irmão desavindo de Haroldo, ou para punir Morcar), sofreu uma emboscada e morreu às mãos de Osulf, o descendente expropriado de um antigo conde de Bernícia. O Norte continuava difícil de dominar e dava o exemplo em matéria de resistência aos Normandos, que de um exército de conquista se tinham convertido numa força de ocupação. Os revoltosos eram muitos e ardiam em desejo de vingar Hastings, mas não dispunham de um controlo unificado e de um propósito comum. Assim, a expressão da sua rebeldia tinha uma incidência regional, fazendo-se sentir em especial a norte, em Exeter (no litoral sudoeste) e na East Anglia. Os anos de 1068 a 1070, sobretudo, seriam extremamente difíceis para os Normandos e são hoje conhecidos como o tempo da "revolta inglesa". Regressado da Normandia, Guilherme iria ter de reagir contra os principais focos de insurreição e fá-lo-ia de uma forma arrasadora. Infelizmente, a crónica de Guilherme de Poitiers, tal como a conhecemos hoje, termina justamente com a morte de Copsi, pelo que, a partir daqui, teremos de nos servir de Orderico Vital (que utilizou Poitiers para os anos seguintes) e de algumas das fontes que selecionámos de início, entre outros materiais.

Em 1068, em Exeter, começaram as perturbações de grande escala: era aqui que residiam Gyda, a viúva do conde Godwin (mãe de Haroldo), e também os filhos de Haroldo e de Edite "colo de cisne". Tratava-se de uma cidade comercial ativa e recusou jurar fidelidade a Guilherme. O rei cercou-a durante 18 dias e forçou a sua rendição; nesta operação, soldados normandos e ingleses terão pela primeira vez combatido lado a lado. Gyda e os netos fugiram para a Irlanda, e o castelo capturado foi entregue a Balduíno de Meules (irmão de Ricardo Fitz Gilbert). Muitos Bretões aproveitaram para se estabelecer em Devon e na Cornualha (numa espécie de 'regresso às origens', 500 anos depois!) enquanto, do outro lado da trincheira, a Escócia e a Irlanda acolhiam numerosos opositores aos Normandos. Esta circunstância ajudou a preparar o cenário para a megarrevolta de 1069, que podemos talvez considerar como a derradeira grande esperança de resistência à ordem normanda em Inglaterra. 
A revolta de 1069 reuniu uma enorme quantidade de oposicionistas e sugere que os territórios anglo-saxões se acomodaram melhor ao novo poder do que as regiões de influência escandinava mais forte, que se mostraram mais renitentes em aceitar o quadro político surgido após a coroação do duque da Normandia. A aliança incluiu Edgar Etheling, o conde Waltheof de Huntingdon e forças da Dinamarca e da Escócia. Um irmão do rei dinamarquês Sven II Estridsen, chamado Asborn, reuniu uma frota de 240 navios longos e, com alguns dos filhos de Sven e com outros grandes (incluindo o bispo de Ahrus, Cristiano), atacou a Inglaterra. Realizaram diversas pilhagens no sul, mas foram repelidos em Dover e em Sandwich e subiram então a costa leste, atacando a East Anglia (Ipswich), onde foram rechaçados pelas forças locais. Como seria de esperar, os Dinamarqueses receberam apoio dos antigos compatriotas instalados na região. Os Normandos, devido ao reforço das defesas costeiras, conseguiram evitar o desembarque várias vezes, mas os Vikings lá acabaram por conseguir juntar-se aos rebeldes nortistas. Estes, contando com fortes apoios locais, avançaram até York, com Waltheof, Edgar, o conde Gospatric (parente de Edgar), os filhos de Karli (da Casa de Bamburg), os líderes dinamarqueses e Malcolm III Canmore (rei da Escócia) à cabeça. No fundo, eram todos os poderes do Norte, passados e presentes, incluindo Escoceses, Ingleses e Dinamarqueses, contra os intrusos normandos. Era uma revolta nortista generalizada!

As perturbações tinham começado a 28 de janeiro de 1069, com um ataque a uma força expedicionária normanda que avançara até Durham. O cronista Simeão de Durham (um monge inglês falecido depois de 1129) diz que os Normandos provocaram o povo com agressões e assassinatos de religiosos. Então, os Nortumbrianos apanharam os Normandos de surpresa, de madrugada, matando muitos, incluindo Roberto de Commines, recentemente designado como conde da Nortúmbria. A seguir, os rebeldes viraram as suas atenções para York: uma força normanda sob o comando de Roberto Fitz Richard (alcaide de Clifford's Tower) ainda tentou uma surtida, mas foi massacrada; muitas centenas de franceses foram mortos, diz a Crónica Anglo-Saxónica. Porém, Guilherme Malet (o homem que sepultara Haroldo) sobreviveu (ficou no castelo com a mulher e dois filhos) e enviou mensagens com pedido de socorro a Guilherme, que veio 
à pressa da Normandia e marchou logo para norte. Os rebeldes fugiram e o rei recuperou York, sem poupar ninguém; construiu então um segundo castelo, que confiou a Guilherme Fitz Osbern; mesmo assim, ainda houve um ataque aos dois castelos normandos, mas o fiel valido aguentou o assalto. Entretanto, a frota dinamarquesa, paga por Guilherme para retirar depois da derrota dos rebeldes, regressou à base em bastante mau estado, segundo conta Orderico Vital.

A seguir, "o Conquistador" puniu a região de uma forma atroz. Simeão de Durham escreve que não havia nenhuma aldeia habitada entre York e Durham e até Orderico Vital, geralmente favorável ao novo rei, disse que "em mais lado algum Guilherme deu mostras de uma tal crueldade. Lamentavelmente, sucumbiu a este vício, pois não fez qualquer esforço para conter a sua fúria e fez pagar o justo pelo pecador... A minha narrativa elogiou com frequência Guilherme, mas, por este ato que condenou de igual modo o inocente e o culpado a morrer de morte lenta, não posso elogiá-lo... Preferirei lamentar as dores e o sofrimento da desditosa gente a ensaiar uma vã tentativa de adular aquele que perpetrou uma tal infâmia" (in Bradbury, pp. 168-169).

Não restam dúvidas de que Guilherme, tomado pela cólera (ao que parece, um sentimento frequente nele), levou longe demais o seu castigo, desejando que toda a região a norte do Humber ficasse desprovida de comida. Destruíam-se as casas e as colheitas (expressamente reunidas para serem queimadas, tal como os arados e outros instrumentos de produção), assim como todas as criaturas vivas que aparecessem pela frente. A carnificina não cessou antes de o Yorkshire ser uma vasta região de cinzas e devastação, facto de que se arrependeria amargamente o rei, no seu leito de morte - tarde demais: entre 5 e 10\% da população inglesa terá sucumbido nesta razia, cujos efeitos ainda eram visíveis seis décadas mais tarde. No meio de tanta vingança, é curioso registar a clemência com que o monarca tratou Edgar Etheling, que foi perdoado. A explicação para este facto deve ter tido que ver com a vontade do rei em fazer a paz com a Escócia: Edgar viveu ali durante bastante tempo após a coroação de Guilherme e, como vimos, casou até uma irmã sua (Margarida) com o rei Malcolm III Canmore (1058-1093). 
O novo monarca ocupou-se também dos focos de revolta que se acendiam mais a ocidente. Os filhos de Haroldo (Godwin, Edmundo e Magno) atacaram por duas vezes a Inglaterra desde a Irlanda, uma primeira vez em 1068 e outra em 1069, desta feita com mais de 60 navios, a partir dos quais devastaram os arredores de Exeter; porém, o conde Brian, um dos mais destacados servidores de Guilherme, obrigou-os a bater em retirada e a regressar à Irlanda. O feito, que terá provocado perto de 1700 baixas, segundo estima Guilherme de Jumièges, acabaria por forçar a avó, Gyda, a deixar Exeter e a partir para o exílio, onde acabaria por falecer. Nos anos de 1069 e 1070, assistiu-se também ao esforço de Guilherme para dominar o País de Gales, que acolhia muitos aristocratas ingleses revoltados. O rei entregou a Marca de Gales a Hugo de Avranches, conde de Chester, colocou Roberto de Montgomery no centro do País de Gales (até Cardigan e ao litoral) e entregou ao filho deste, Arnulfo, o castelo de Pembroke. Quanto ao sul de Gales, foi confiado ao inevitável Guilherme Fitz Osbern, mas, a partir de 1075, com a traição do filho deste, Guilherme passaria a ocupar-se pessoalmente da região. Diversos fiéis do novo monarca receberam neste período senhorios militares e castelos em Gales.

Em 1071, foi a região da East Anglia que mais absorveu as atenções dos novos senhores da Inglaterra. Confrontado com a rebelião de Hereward, possivelmente um thegn do Lincolnshire, que se pensa ter sido proscrito depois de ter atacado um senhor normando e que contaria com o apoio dos condes nortistas, Guilherme foi enfrentá-lo pessoalmente: venceu-o, mas Hereward conseguiu fugir e acabaria por se tornar uma lenda imortalizada na Gesta Herewardi, composta no séc. XII. Nesta campanha, Morcar, o antigo conde da Nortúmbria, ficou preso para sempre, enquanto o seu irmão Edwin, o velho conde da Mércia, terá sido morto ao tentar libertá-lo (segundo explica Orderico Vital).

Seguiu-se a campanha na Escócia, em 1072. Guilherme, que, como vimos, dominara todo o Yorkshire em 1069, utilizou a frota normanda para bloquear os portos escoceses, forçando desse modo Malcolm a submeter-se e a prestar homenagem ao novo monarca. É provável que o acordo tenha incluído Edgar Etheling, que então trocou o seu refúgio na Escócia pelo exílio na Flandres. No entanto, em breve o neto de Edmundo Ironside andaria 
pela corte de Guilherme I, que evidenciou uma rara tolerância para com ele. Assim, Edgar acabou por ter uma vida relativamente longa e chegaria mesmo a participar na Primeira Cruzada na Terra Santa (em 1096-1099).

Em 1075, teve lugar a revolta dos barões da Bretanha que tinham acompanhado Guilherme e recebido domínios em Inglaterra. Os rebeldes estavam descontentes com o poder excessivo do rei (graças ao sistema jurídico anglo-saxónico) e, talvez, com as exigências financeiras resultantes das suas expedições incessantes ao continente. Os líderes desta revolta foram Rodolfo de Gaël, conde de Norfolk (na East Anglia), que era meio bretão e meio inglês, e Rogério Montgomery, de Hereford; o conde Waltheof de Huntingdon (por sinal casado com uma sobrinha de Guilherme: Judite) também foi convidado, mas recusou. Ao saber da conspiração, o arcebispo Lanfranc (que era então o regente de Guilherme em Inglaterra) escreveu logo ao rei, que se encontrava na Normandia, a dar conta do sucedido; todavia, pediu-lhe que ficasse onde estava, prometendo-lhe que os barões mais fiéis tratariam do assunto. E, de facto, assim foi: Rodolfo, forçado a retirar-se para Norwich, confiou a defesa da praça à sua jovem esposa (uma filha de Guilherme Fitz Osbern) e foi por mar buscar auxílio à Dinamarca; voltou algum tempo depois, com um filho de Sven Estridsen (Cnut, o futuro São Cnut) e com um "jarl" (isto é, um conde) chamado Hakon, à cabeça de 200 navios; porém, quando chegaram ao Norfolk, já Norwich tinha caído às mãos de Guilherme Warenne, de Godofredo de Coutances e de Odão de Bayeux... Os Dinamarqueses não puderam, pois, fazer mais do que as suas tradicionais rapinas predatórias antes de se retirarem. Os condados de Hereford, Nortúmbria e East Anglia foram extintos e Rodolfo teve de se refugiar na Bretanha, enquanto outros insurretos foram presos e punidos: foi o caso de Rogério Montgomery, que ficou detido para sempre; quanto ao conde Waltheof, foi convocado pelo rei Guilherme e acusado de traição e deslealdade pela própria mulher Judite, conta Orderico Vital! Em conformidade, foi preso durante um ano em Winchester e, depois, foi executado, isto apesar de Guilherme ter interditado a pena de morte, salvo por assassinato. Como observou Mogens Rud, a brutalidade com que foi tratado o último conde anglo-saxão pode ter tido que ver com o facto de ele ser filho de um conde nórdico (Siward): temia-se uma influência 
perigosa sobre o elemento dinamarquês-norueguês, que permanecia vivo em Inglaterra, e sobre o poder marítimo dinamarquês, ainda muito expansionista. Na Bretanha, Rodolfo continuou a dirigir a insurreição contra Guilherme, ao longo de toda a fronteira normanda, obrigando-o a combates constantes e nem sempre favoráveis; para tal, contou com o apoio do rei de França, Filipe I (1060-1108).

Em 1079, Guilherme travaria, por intermédio do seu filho Roberto (conhecido por Roberto Courteheuse, por usar umas calças bastante curtas), a sua última grande batalha em Inglaterra, respondendo a uma incursão devastadora de Malcolm da Escócia na Nortúmbria. Na sequência desta operação, o rei mandou construir castelos importantes, como o de Newcastle-on-Tyde, em 1080; mais tarde, o seu filho e sucessor, Guilherme II "o Ruivo", prosseguiria esta política: em 1092, ergueu uma fortaleza em Carlisle e também chamou camponeses do sul de Inglaterra para repovoar esta região duplamente devastada.

A partir de 1080, os maiores problemas de Guilherme I tiveram origem na sua família mais próxima. Em 1083, o meio-irmão e seu apoiante de primeira hora, Odão, bispo de Bayeux, viu abrir-se-lhe uma janela de oportunidade para conseguir chegar ao papado. Decorria então a chamada Querela das Investiduras, uma disputa violenta entre o papa Gregório VII e o imperador Henrique IV, a propósito da nomeação dos bispos. O conflito obrigara mesmo Gregório a fugir de Roma e levara o imperador a escolher um antipapa do seu agrado: Clemente III. Aproveitando o cisma, Odão reuniu o apoio de um grupo de cavaleiros ingleses e dos normandos que tinham conquistado a Sicília na década de 1060 e preparou-se para se lançar nesta nova aventura. Guilherme, porém, soube a tempo e travou o projeto, que, segundo muitos autores, pode também ter envolvido uma conspiração contra "o Conquistador". O facto é que Odão foi detido e só viria a ser libertado após a morte do rei, tendo mais tarde conspirado contra o sucessor deste.

No entanto, o golpe mais duro contra Guilherme veio de Roberto Courteheuse, o seu filho mais velho. O rei destinara-lhe o ducado da Normandia, mas não pretendia que este assumisse o título e o cargo antes da sua morte: "não tenho por hábito despir-me antes de me deitar", dizia o monarca. Roberto, porém, ardia em impaciência e parece que contava 
com o apoio anímico e financeiro da mãe, Matilde; a determinada altura, aliou-se a alguns rebeldes e cercou Rouen; porém, o comandante da praça resistiu e conseguiu receber socorro, pelo que o ataque foi repelido. Conta a Crónica Anglo-Saxónica que, na sequência deste conflito, "Roberto combateu contra o seu pai e feriu-o numa mão; o cavalo de Guilherme foi abatido debaixo dele e o homem que lhe trouxe um outro foi abatido com um tiro de besta; muitos foram mortos e feitos prisioneiros. E Roberto retirou-se para a Flandres. Nós não queremos escrever mais acerca do dano que ele fez a seu pai..." (in M. Rud, p. 94).

No verão de 1086, Guilherme teve notícia de uma conspiração entre Roberto e Filipe I de França contra a Normandia. Em finais de julho de 1087, o rei de Inglaterra e duque da Normandia atacou Nantes. Na sequência de uma queda, bateu fortemente no arção do seu cavalo e sofreu uma grave lesão interna; seguiram-se várias semanas de agonia em Rouen. No seu leito de morte, o rei perdoou a Roberto Courteheuse e confirmou-o como duque da Normandia; ao mesmo tempo, indicou o filho Guilherme "o Ruivo" como seu sucessor em Inglaterra.

A 9 de setembro de 1087, Guilherme "o Conquistador" exalou o seu último suspiro no priorado de São Gervásio, no exterior de Rouen. Nessa altura, já estava extremamente gordo e sofria muito de gota; tinha então cerca de 60 anos. Orderico Vital deixou-nos uma descrição da morte de Guilherme e explica que ele teve um último sono calmo, tendo falecido enquanto dormia. A morte do grande comandante suscitou naturais reações de consternação e de júbilo. A confusão parece ter sido geral, com receio do que poderia acontecer, e cada um tentava proteger os seus bens o melhor que podia. Os exilados normandos em Roma e na Calábria souberam da ocorrência no próprio dia, refere Orderico, um facto que é obviamente impossível, mas que revela a ansiedade de muitos oposicionistas. Alguns clérigos organizaram uma procissão e foram buscar o corpo do rei a São Gervásio; levaram-no de barco e providenciaram o transporte do féretro para o túmulo; porém, deflagrou um incêndio pavoroso numa casa próxima e isso lançou o pânico no cortejo, pelo que só alguns monges acompanharam o corpo até à sua última morada, na Abbaye-aux-Hommes, em Caen. 
Desde então, o túmulo de Guilherme foi aberto pelo menos duas vezes: no Renascimento e na Revolução Francesa. Nesta última ocasião, os restos mortais que subsistiam foram roubados, pelo que hoje não sobra nenhum testemunho material do homem que interpretou uma das mais completas e eficazes conquistas da história europeia.

\section{As consequências imediatas da conquista}

A vitória conseguida em Hastings e o sucesso obtido, a ferro e fogo, no estrangulamento dos vários núcleos de revolta ao longo dos anos seguintes tiveram como efeito imediato a afirmação de um novo rei, de uma nova nobreza e de uma nova classe governante na Inglaterra dos finais do séc. XI. Como notou Jim Bradbury, apesar de Guilherme ter começado a exercer o poder de uma forma cautelosa e até tolerante, as circunstâncias empurraram-no para um progressivo endurecimento da sua forma de atuar e explicam que, dez anos depois da conquista, a grande nobreza de Inglaterra fosse já de extração continental, ainda que possuindo algum sangue inglês devido aos casamentos que foram sendo realizados com damas de origem inglesa.

Todos os autores têm salientado a grande atração dos Normandos pelas riquezas de Inglaterra - então um dos reinos mais prósperos da Europa - e a enorme avidez de ouro revelada por Guilherme "o Conquistador". Logo em 1067, houve lugar a uma ampla distribuição de terras a apaniguados do novo rei, a igrejas e a abadias. Aliás, só os bens eclesiásticos foram respeitados, pois Guilherme era sensível à influência da Igreja, e esta colaborava no esforço de guerra dos Normandos: em 1071-1072, por exemplo, a defesa da costa sul foi, em grande parte, assegurada por cavaleiros oriundos das terras pertencentes à Igreja.

Politicamente, foi como se tivesse principiado um mundo novo na ilha que outrora os Anglo-Saxões haviam conquistado. Veja-se que, em 1272, subirá ao trono um rei chamado Eduardo, de resto um dos mais notáveis da história da Inglaterra medieval e que governaria até 1307. Ora, este rei 
intitulou-se "Eduardo I", como se os Eduardos que o tinham precedido no trono inglês (Eduardo “o Antigo", entre 899 e 925, Eduardo “o Mártir”, entre 975 e 978, e, sobretudo, Eduardo “o Confessor", entre 1042 e 1066) tivessem sido esquecidos ou fossem simplesmente recordados como governantes de um reino diferente...

A visão dos autores anglo-saxónicos coevos acerca dos efeitos da conquista normanda é bastante pessimista. Guilherme de Malmesbury, por exemplo, na obra De Gestis Regum Anglorum (c. 1125), afirma que o 14 de outubro de 1066 foi um "dies fatalis" para a Inglaterra. A velha nobreza foi extinta e, em 1086, já só restariam dois chefes: Thurkill d'Arden e Colswei de Lincoln; tudo o mais fora morto, preso, expropriado ou exilado na Escócia e na Dinamarca [já para não falar na Rússia ou até em Bizâncio, onde também é possível encontrarmos nobres ingleses no último quartel do séc. XI]. Alguns autores recentes (como Elisabeth van Houts) enfatizaram este facto e calcularam que 50\% da nobreza de Inglaterra terá sido liquidada em Hastings. Muitas mulheres inglesas foram empurradas para casamentos indesejados ou para o silêncio dos mosteiros, ao mesmo tempo que muitas propriedades e casas foram destruídas, designadamente para se construírem castelos nos mesmos lugares, como sucedeu em Exeter ou em Cambridge. Claro que tudo isto só foi exequível graças a uma dominação musculada, o que permitiu impor um nível de taxação sem precedentes e fez com que muitos sheriffs de Inglaterra tenham começado a ser odiados bastante antes do aparecimento da figura semilendária de Robin Hood (em inícios do séc. XIII)...

Esta leitura dos acontecimentos precisa de ser matizada. Parece certo que a maior parte dos domínios dos adversários de Guilherme foi confiscada e que vastos territórios foram cedidos a Normandos e a aliados que o tinham apoiado na conquista. Sabe-se, aliás, que muitas viúvas e órfãos de Ingleses mortos na colina de Senlac tiveram de recomprar as suas próprias terras a preços exorbitantes. Também é verdade que foram exigidos impostos pesadíssimos e que os próprios senhores da Normandia se espantaram com a quantidade de ouro, de prata e de objetos preciosos que Guilherme lhes deu de presente aquando do seu regresso de Hastings. No entanto, convém não exagerar no sentido e no significado das mudanças: a conquista quase 
não modificou as instituições anglo-saxónicas, nomeadamente as de base (os shires e as hundreds), nem as taxas, nem a moeda. Muita da sociedade da velha Inglaterra sobreviveu. O sistema agrícola permaneceu o mesmo, muitas famílias médias atravessaram a crise sem alterações significativas, e os escalões inferiores do serviço régio continuaram a ser preenchidos essencialmente por Ingleses. Embora tenha deixado de ser a língua do governo e da religião (onde foi substituída pelo latim e pelo francês), o inglês continuou a ser a língua falada pelo povo comum; se é verdade que muitos termos franceses enriqueceram o inglês, especialmente na linguagem do governo, da administração e da legislação (o francês tornou-se a língua da corte, falada pela classe superior de Inglaterra durante 150 anos), também é certo que na agricultura e nas pescas entraram poucos termos de origem francesa.

Um dos aspetos em que podemos detetar uma significativa mudança, que ajudou a alterar e a colorir a 'paisagem inglesa', foi a construção de castelos privados, até aí desconhecidos. Estima-se que, na Inglaterra de 1100, houvesse já cerca de 1000 castelos (e não fortificações urbanas como aquelas cuja construção Alfredo "o Grande" havia incentivado: os buhrs), erguidos a intervalos de cerca de $25 \mathrm{~km}$ - o equivalente a um dia de marcha da cavalaria -, para se poderem defender uns aos outros. Esta explosão é fácil de explicar: os Normandos que residiam em Inglaterra eram perto de 10 000, apenas, e precisavam dos castelos para se protegerem de uma população que, em grande medida, lhes era hostil, sobretudo nas regiões que atrás identificámos (no sudoeste, na East Anglia e a norte).

Também o exército foi profundamente renovado: a partir de então, a Inglaterra passou a dispor de uma elite de tropas a cavalo (segundo o modelo normando), a par da sua tradicional infantaria de qualidade, o que tornou o exército anglo-normando um dos mais poderosos da Europa do seu tempo. Também o caminho, já iniciado, de articulação entre a posse da terra, por um lado, e a prestação do serviço militar, por outro, foi acelerado. Com isto, o serviço militar de tipo feudal desenvolveu-se; sabe-se que, em finais do séc. XI, só os senhores eclesiásticos (grandes proprietários fundiários) deviam ao rei 780 cavaleiros, que viviam alojados com o respetivo senhor ou agrupados em pequenas tenências situadas junto ao castelo senhorial. 
O serviço de hoste (participação em grandes expedições defensivas ou ofensivas do senhor feudal) fixou-se nos 40 dias, embora, a partir de 1100 (com o rei Henrique I), se verifique uma tendência para a substituição do serviço militar presencial por uma taxa pecuniária (o scutage). No seu conjunto, o exército feudal da Inglaterra de 1100 devia reunir entre 5000 e 7000 cavaleiros. Para uma mobilização eficaz, era essencial a ação do monarca: em Inglaterra, não existia a "pirâmide vassálica" típica do continente (em especial da França), e a homenagem era prestada diretamente ao rei, por parte dos respetivos tenentes e subtenentes.

Devemos também enfatizar as mudanças rapidamente registadas no seio da Igreja, em especial ao nível dos grandes prelados. Os que se encontravam em funções em 1066 continuaram, mas à sua morte foram substituídos por prelados continentais. Cerca de 1073, existiam em Inglaterra 8 bispos normandos, 4 lotaríngios, 2 ingleses e 1 italiano; em 1087, havia 11 bispos normandos e apenas 1 inglês (in J. Bradbury, p. 177); nas abadias, o processo foi mais suave, mas a tendência foi a mesma. Quanto ao controverso arcebispo Stigand, foi deposto em 1070 e substituído por Lanfranc, que, embora não fosse um normando, tinha exercido cargos de relevo na igreja normanda antes de 1066 e era íntimo de Guilherme; elevado a arcebispo de Canterbury, a ele se deve a grande reforma da igreja inglesa no derradeiro quartel do séc. XI. Esta reforma incluiu a construção de bastantes igrejas (muitas das quais substituíram os antigos templos ingleses), assim como a relocalização das sés, desviadas para posições mais urbanas e centrais (ex.: a de Lichfield passou para Chester). Muitos clérigos foram então introduzidos no aparelho administrativo, o que ajuda a explicar a afirmação do latim em detrimento do inglês. Enquanto Lanfranc dominou (até 1089, data da sua morte), nenhum bispo ou abade de origem inglesa foi eleito. A proximidade deste prelado em relação ao papa Alexandre II e aos reformadores eclesiásticos não só acentuou o domínio francófono na Igreja inglesa como fez com que esta tivesse evoluído no sentido de uma maior universalidade, tendo-se suprimido o calendário dos santos ingleses e preferido a liturgia de Cluny em detrimento da liturgia local, entre outras mudanças. 
Em termos económicos, e para além do já referido agravamento da carga fiscal, há um aspeto que merece uma atenção particular, até pelas reclamações que suscitou. Com os reis normandos, a Inglaterra tornou-se um país de florestas (nos finais do séc. XII, elas representarão cerca de um quarto do território!). E isto principiou logo com Guilherme "o Conquistador", que providenciou a organização de uma enorme coutada no Hampshire, em face da Ilha de Wight, ainda hoje conhecida como New Forest. Para tal, Guilherme colocou mais de 27500 hectares de terra em baldio e ainda confiscou para cima de 5500 hectares de terra cultivada, associados a 20 aldeias; depois, para evitar a caça furtiva, tratou de deslocar 500 famílias. A Crónica Anglo-Saxónica não deixa passar em claro esta política de criação de enormes reservas de caça a favor da realeza. Na versão $\mathrm{E}$ desta fonte, na entrada alusiva a 1087 (num passo em que avalia a ação governativa de Guilherme, falecido nesse mesmo ano) o cronista escreveu o seguinte: "Ele criou vastas florestas para os veados e os gamos e amava-os como se fosse seu pai. Além disso, decretou que as lebres pudessem circular livremente. Os poderosos queixavam-se e os pobres lamentavam-se, mas ele era tão decidido que não se preocupava com o rancor que suscitava" (in Cassagnes-Brouquet, p. 72).

Descendo ao pormenor, teremos ainda de referir um documento único na história europeia, mandado fazer por Guilherme por volta do ano 1085. O rei temia uma nova invasão dinamarquesa e sentiu necessidade de prever a cobrança rápida de um imposto, caso a ameaça viking se concretizasse. Mas, para isso, carecia de um instrumento administrativo: um inventário rigoroso dos bens que havia em Inglaterra e dos recursos que eram devidos ao rei. Foi assim que nasceu o Domesday Book, ou "Livro do Juízo Final", uma designação irónica que lhe foi atribuída pelos Ingleses a partir da palavra "dom", que no inglês antigo significava "contabilidade" ou "avaliação". Podemos considerar o Domesday Book como herdeiro dos recenseamentos anglo-saxónicos levados a cabo a partir de Alfredo "o Grande” (871-899), mas supera-os largamente.

Nesta inquirição, realizada entre 1085 e 1087, todos os habitantes, todas as terras, propriedades, instrumentos de produção e outras riquezas foram recenseados minuciosamente, o que torna este documento uma verdadeira "dádiva de Deus", para utilizar a expressão de Jim Bradbury. 
Como explica Sophie Cassagnes-Brouquet, todos os homens do reino eram obrigados a responder, após terem prestado juramento perante o respetivo sheriff (o shire reeve, isto é, o preboste do condado): os barões, todos os franceses, todas as hundreds (subdivisões dos shires), todos os padres, o preboste do senhorio e seis camponeses de cada aldeia. Era apresentada uma lista de perguntas tipificada, onde se inquiria o nome da aldeia e quem a detinha ao tempo do rei Eduardo "o Confessor" e em 1086. Perguntava-se também qual o número de hides (as unidades de exploração agrícola afetas às famílias camponesas), de bosques, de prados e de pastagens, quantos moinhos e quais as variações surgidas a este respeito depois da conquista. O rei queria ainda saber quantos terrenos aráveis num dia (as chamadas charruées, equivalentes a c. 12 jeiras) havia no domínio senhorial e entre os camponeses, quantos homens livres, vilãos, escravos e outras categorias sociais havia em cada aldeia e quanto é que cada uma delas possuía de terra. As respostas deviam considerar, em cada alínea, três datas diferentes: ao tempo do rei Eduardo, no momento em que Guilherme concedera o feudo e, por fim, em 1086. Os inquiridores interrogavam também as testemunhas para apurarem se seria possível os domínios renderem mais.

Para efeitos deste trabalho monumental, o reino foi dividido em seis ou sete círculos, tendo-se deixado de fora apenas o bispado de Durham (no norte), considerado muito afastado, e as cidades de Londres e de Winchester, tidas por demasiado complexas. Guilherme escolheu, para cumprir esta missão, laicos e eclesiásticos de grande autoridade. Num primeiro momento, todos os principais tenentes do rei forneciam pormenores acerca das honras que possuíam; a seguir, as informações eram reunidas por ocasião de uma segunda sessão, que tinha lugar na corte condal; aí, os inquiridores controlavam as informações recolhidas bundred por bundred; por fim, reuniam-se todos em Winchester para centralizar e uniformizar, em cadernos encadernados e muito bem ordenados (ao que parece, por um mesmo escrivão!), redigidos em latim mas com inserção de alguns termos vernáculos, os resultados do inquérito.

Tendo chegado até nós, estes cadernos fornecem ao historiador um retrato extraordinariamente fiel da situação económica e social na Inglaterra dos finais do séc. XI. Mesmo em Inglaterra, não há nada que se possa com- 
parar com isto até aos censos realizados no séc. XIX. Através do Domesday Book conseguimos, por exemplo, saber qual era, grosso modo, a distribuição da propriedade em Inglaterra no ano da morte de Guilherme (1087): $17 \%$ pertencia ao rei, 26,5\% à Igreja, 48,5\% aos invasores normandos (em especial aos meios-irmãos de Guilherme: Odão de Bayeux e Roberto de Mortain), apenas 5,5\% a tenentes ingleses (o que vem dar alguma razão às visões mais pessimistas dos autores anglo-saxónicos) e os restantes 2,5\% a oficiais e servidores do rei. Percebe-se também que Guilherme procedeu com astúcia à doação de terras a apaniguados seus: essas propriedades encontravam-se dispersas pelo território, de maneira a evitar a formação de uma aristocracia demasiado forte... Entre aqueles que mais lucraram com a batalha de Hastings e com a conquista que de imediato se lhe seguiu, encontravam-se muitos normandos, mas também gente do Boulonnais, da Picardia, da Flandres e da Bretanha. No interior da comunidade normanda, os beneficiários eram sobretudo os membros da família ducal e os fiéis mais próximos de Guilherme (p. ex.: Ricardo, conde de Évreux; e Ricardo, o filho do conde de Brionne). Percebemos também que os alcaides dos castelos reais e os sheriffs, cujo poder cresceu bastante com o já referido desaparecimento dos earls (os antigos condes), eram escolhidos no seio da nobreza normanda.

Também é interessante olhar para o mundo urbano da Inglaterra a partir do Domesday Book. Esta fonte mostra-nos uma sociedade ainda muito rural, com uma centena de burgos de tamanho variável: 19 cidades tinham entre 1000 e 2500 habitantes, 9 cidades situavam-se entre os 3500 e os 5000 moradores (entre as quais Oxford, Canterbury, Gloucester e Norwich) e poucas ultrapassavam os 5000 habitantes - era o caso, por exemplo, de Lincoln, e também o caso de York, que já tinha mais de 8000 moradores distribuídos por 1607 casas (ao tempo de Eduardo "o Confessor"). Não se esqueça, no entanto, que Londres, a maior cidade inglesa, ficou de fora deste recenseamento. Em algumas cidades, a conquista normanda parece ter tido resultados catastróficos: Oxford tinha, em 1087, apenas 243 lares para pagar o famoso "geld" (que em 1129-1130 já representaria 10\% do rendimento anual da coroa), enquanto 478 casas se encontravam vazias ou em ruína. Ainda assim, a Inglaterra era um dos países mais urbanizados da Europa coeva, com cerca de 10\% de citadinos. 
O Domesday Book foi a última 'grande obra' de Guilherme "o Conquistador", que faleceria poucas semanas depois da conclusão do inquérito. O autor da entrada de 1087 inserta na versão E da Crónica Anglo-Saxónica, que há pouco citámos, e que diz ter conhecido pessoalmente o grande rei por ter passado algum tempo com ele na corte de Inglaterra, despede-se do monarca nos seguintes termos: "O rei Guilherme (...) era um homem muito sábio e muito poderoso, muito respeitado e mais poderoso do que todos os seus predecessores. Ele era clemente com os homens de bem que amavam Deus e severo para além de toda a medida para com aqueles que resistiam à sua vontade. Ele fundou uma célebre abadia no próprio local onde Deus the tinha permitido conquistar a Inglaterra e instalou aí monges e dotou-os ricamente. Foi sob o seu reinado que foi construída a famosa catedral de Canterbury e muitas outras igrejas em todo o reino. O reino estava repleto de monges que viviam sob a regra de São Bento e a cristandade era tal no seu tempo que todo o homem que o desejasse se juntava a esta ordem. O rei Guilherme era muito cioso da sua dignidade; três vezes por ano, ele ostentava a coroa quando se encontrava em Inglaterra: na Páscoa, em Winchester; no Pentecostes, em Westminster; e no Natal, em Gloucester. Nestas ocasiões, todos os grandes de Inglaterra, arcebispos e bispos, abades e condes, thegns e cavaleiros o rodeavam. Ele era também um homem duro e tão violento que ninguém ousava ir contra a sua vontade. Ele expulsou bispos das suas sés e abades dos seus mosteiros e colocou thegns na prisão e, para terminar, não poupou sequer o seu próprio irmão, que se chamava Odão; este era um muito poderoso bispo da Normandia (a sua catedral encontrava-se em Bayeux) e era o primeiro servidor do rei e possuía um condado em Inglaterra. E quando o rei se encontrava na Normandia, Odão era o senhor de Inglaterra. O rei mandou-o lançar na prisão. É preciso acrescentar que este rei fez reinar a segurança no país - assim, todo o homem honesto podia circular no seu reino com a bolsa repleta de ouro, sem ser inquietado, e ninguém ousava matar para se vingar, qualquer que fosse a ofensa. E se um homem se tinha entretido com uma mulher contra a vontade desta, era logo castrado. (...) Sob o seu reinado, o povo conheceu uma grande opressão e muitos males. Ele mandou construir castelos e oprimiu os pobres. Era tão duro que tomou aos 
seus súbditos muitos marcos de ouro e muitas centenas de libras de prata, por força e sem justificação. Era avaro e cúpido o mais possível. (...) Todos deviam aceitar a sua vontade se queriam salvar a vida, conservar as suas terras, propriedades e posições ou o seu favor. Ai Jesus!, que infelicidade que um homem se possa ter conduzido com tanto orgulho e se tenha colocado acima de todos os outros. Possa o Senhor todo-poderoso ter piedade da sua alma e perdoar-lhe os seus pecados" (in Cassagnes-Brouquet, pp. 71-73).

\section{Os sucessores de Guilherme e as consequências de longo prazo}

Como já explicámos, os últimos tempos de Guilherme "o Conquistador" foram marcados por lutas diversas (sobretudo na Normandia), pela doença (gota) e pelo receio das perturbações que poderiam seguir-se à sua morte.

Não se enganou. Quando faleceu, em setembro de 1087, sucedeu-lhe no trono de Inglaterra o filho Guilherme "o Ruivo”. Este Guilherme II (1087-1100) era apenas o terceiro filho resultante do casamento de "o Conquistador" com Matilde da Flandres; ascendeu ao trono por morte prematura do irmão Ricardo (falecido 10 anos antes) e porque, como já sabemos, o rei destinara ao irmão mais velho, Roberto Courteheuse, o ducado da Normandia.

Guilherme II revelou ter herdado as qualidades militares do pai. Fez campanha na Cúmbria (no nordeste de Inglaterra, junto à fronteira com a Escócia), no sul de Gales e na Normandia, território continental que o irmão Roberto lhe cedeu por quatro anos quando partiu para a Primeira Cruzada, em 1096. Aqui, Guilherme "o Ruivo" atacou o Maine e o Vexin e mandou erguer uma fortaleza em Gisors. Apesar de ter promovido a ascensão de 'homens novos' (jovens cavaleiros e vassalos oriundos da Normandia), Guilherme II manteve diversos conselheiros do pai junto de si, em especial Ranulfo Flambard, pelo que se compreende bem que as fontes eclesiásticas considerem o novo monarca como um outro déspota, ao mesmo tempo que autores como Guilherme de Malmesbury o retratam como um cavaleiro modelo, forte, bravo e generoso. Curiosamente, "o Ruivo” nunca casou, o que era raro num príncipe da sua envergadura. Em 1088, teve de enfrentar uma perigosa conspiração liderada pelos seus tios Odão e Roberto de 
Mortain (apoiada por Roberto Courteheuse), facto que conduziria à detenção de Mortain e à fuga de Odão. Ironicamente, o mandante da Tapeçaria de Bayeux acabaria por morrer em Palermo, na Sicília normanda, expropriado de todos os seus bens, em 1097.

Em 1100, Guilherme "o Ruivo" morreu num acidente de caça na New Forest. Nessa altura, Roberto Courteheuse estava ainda na Terra Santa e não pôde reclamar a coroa. Quem tirou partido disso foi o irmão mais novo, Henrique, o primeiro filho de Guilherme e de Matilde a nascer na velha Bretanha romana (em 1068); um segundo filho de "o Conquistador" tornava-se, assim, rei de Inglaterra. Henrique I teve um reinado longo (1100-1135) e inspirador, tendo vivido a maior parte do tempo (em especial nos últimos 29 anos do seu reinado) na Normandia, enfrentando adversários como o rei de França (Filipe I e, a partir de 1108, Luís VI) ou o conde de Anjou. Casou com Matilde, filha do rei da Escócia e descendente de Alfredo "o Grande", e os eclesiásticos dizem que foi um rei sábio e justo, o que lhe valeu o cognome de Beauclerc ("bom clérigo"); porém, autores como o célebre João de Salisbúria (c. 1115-1180) afirmam que ele era cruel e avaro, tendo-se mostrado obcecado com possíveis conspirações contra a sua vida e com a garantia da lei e da ordem, tornando-se um verdadeiro "leão da justiça". Um dos maiores problemas que Henrique I teve de enfrentar foi a contestação do seu irmão Roberto Courteheuse: quando voltou das Cruzadas, o duque reclamou o trono de Inglaterra e revoltou-se contra Henrique I, que veio à Normandia para o combater. Em 1106, em Tinchebrai, numa batalha que é hoje uma referência por ser um exemplo muito precoce de utilização da cavalaria desmontada, Henrique derrotou Roberto e meteu-o na prisão de Cardiff, onde Courteheuse penaria durante 28 longos anos, até falecer. Está hoje sepultado na catedral de Gloucester, em traje de cruzado, com cota de malha e uma coroa ducal alusiva à Normandia. Terminava assim, ingloriamente, a saga de um homem que falhou em quase tudo: na revolta contra o pai (Guilherme "o Conquistador"), na administração do ducado da Normandia, na revolta contra Guilherme II (em 1088) e, por fim, em Tinchebrai, em 1106...

Um filho de Courteheuse, chamado Guilherme Clito, tentou continuar a campanha do seu pai, mas também não teve sucesso perante o tio. A boa 
estrela de Henrique I confirmou-se na luta contra os rebeldes normandos liderados por Waleran de Meulan, que conseguiu vencer numa célebre batalha travada em Bourgthéroulde, em 1124. Este combate configura um outro exemplo de utilização sábia de cavalaria a combater a pé, para além de constituir um exemplo magnífico e precoce de intervenção decisiva dos atiradores com arco, que decidiram a refrega.

Quando faleceu Henrique I Beauclerc, em 1135, os seus dois filhos varões já tinham morrido (um na infância e outro, Guilherme, durante um naufrágio ocorrido 15 anos antes); quanto à filha, Matilde, enviuvara em 1125 do imperador Henrique V e casara em segundas núpcias com Godofredo Plantageneta, filho do conde de Anjou. Parece que Henrique I queria muito que Matilde lhe sucedesse no trono, mas não teve tempo para impor isso aos seus barões.

Assim, em dezembro de 1135, subiu ao trono de Inglaterra um neto de Guilherme "o Conquistador": chamava-se Estêvão e era um sobrinho muito estimado de Henrique I, sendo filho de Adélia, a filha mais nova de Guilherme I (casada com Estêvão, conde de Blois); reinou entre 1135 e 1154 e, apesar de ter sido muito popular em Inglaterra, não se pode dizer que tenha tido muito sucesso. Em 1141, em Lincoln, foi derrotado numa batalha e preso por uma coligação de barões próximos da sua prima Matilde, 'a imperatriz' (a citada filha de Henrique I), mas a esposa conseguiu providenciar a sua libertação. Isto obrigou Matilde a uma fuga dramática de Oxford, em 1142, através da neve, mas um jovem filho dela, chamado Henrique, assumiu então as despesas da oposição ao rei Estêvão, mergulhando o reino num período de anarquia. A morte de Eustácio, o filho mais velho do monarca, em 1153, deve ter sido sentida como um alívio em Inglaterra, pois permitiu que, no ano seguinte, a sucessão de Estêvão fosse assegurada tranquilamente pelo jovem Henrique.

Henrique II, bisneto de Guilherme "o Conquistador", reinou em Inglaterra entre 1154 e 1189. Sendo filho de Matilde 'a imperatriz' e de Godofredo Plantageneta, conde de Anjou, tinha herdado do pai, em 1151, o condado angevino. No ano seguinte, casaria com Leonor da Aquitânia, uma das mulheres mais poderosas da França e que fora casada com o próprio rei Luís VII, de quem se divorciara. Deste modo, a partir de 1154, Henrique II 
conseguiu reinar sobre toda a Inglaterra e sobre uma terça parte (ou mais) da França, o que o tornou um dos soberanos mais importantes de toda a Europa.

Esta evolução acentuou uma tendência desenhada a partir de Hastings: a do entrelaçamento entre os assuntos insulares e continentais (normandos e não só). Cada vez mais membros da nova nobreza de Inglaterra possuíam terras do outro lado do Canal da Mancha. Henrique II governava sobre a Escócia, a Irlanda, a Inglaterra, Gales, a Normandia, a Bretanha, o Maine, o Anjou, o Poitou e a Aquitânia! Tratava-se de um verdadeiro 'império angevino', e isso acarretou um conflito inevitável com os reis capetíngios da França. As guerras entre Filipe Augusto (rei de França) e João Sem Terra (rei de Inglaterra), nos inícios do séc. XIII, ou a própria Guerra dos Cem Anos (1337-1453) só podem ser compreendidas a esta luz. O efeito de tudo isto foi de tal forma duradouro que o litígio se arrastou até meados do séc. XV, altura em que - com a vitória na Guerra dos Cem Anos - a França que hoje conhecemos nasceu e a Inglaterra se viu, enfim, despojada de quase todas as possessões continentais. Mergulhou então numa profunda depressão interna, que a sanguinária "Guerra das Duas Rosas" (1455-1471: a rosa branca de York versus a rosa vermelha da casa de Lancaster) tão bem ilustra.

O referido entrelaçamento entre os assuntos insulares e continentais refletiu-se também, durante três séculos, na evolução do comércio. A Inglaterra afastou-se do mundo escandinavo e centrou-se no cosmos medieval francocêntrico. Já no séc. XII, em Londres, era fácil encontrarem-se mercadores de Rouen, da Île-de-France, do Ponthieu e da Flandres (e também da Alemanha), que trocavam lã por metais preciosos, por vinho e por especiarias.

Ao mesmo tempo, os efeitos de longo prazo da conquista normanda de 1066 fizeram-se sentir no plano de uma maior unidade política da Inglaterra. Como vimos, a linhagem de "o Conquistador" impôs-se longamente (o que não sucedera com os reis dinamarqueses), e isso facilitou a dominação dos vizinhos insulares. No entanto, convém frisar que o Norte de Inglaterra nunca foi inteiramente dominado e que o 'separatismo nortista' permaneceu vivo. De qualquer modo, é indesmentível que os magnates ingleses perderam poder em benefício do rei: nenhum barão anglo-normando dispôs alguma vez da autoridade que tinha tido, em meados do séc. XI, o velho conde Godwin de Wessex. 
No que diz respeito à reforma da Igreja, o séc. XII ampliou fortemente as tendências que detetámos atrás para as últimas décadas da centúria anterior. Intensificou-se o movimento de construção ou reconstrução de abadias e de catedrais, como em York ou em Londres (catedral de São Paulo); não por acaso, uma grande parte das novas igrejas abaciais seguiu o modelo arquitetónico de Santo Estêvão de Caen, na Normandia. Em matéria de vivência religiosa, foi extraordinário o avanço da Ordem de Cluny em Inglaterra, na primeira metade do séc. XII: em 1135, à morte de Henrique I, já havia 24 abadias cluniacenses na velha Bretanha. Um dos netos de "o Conquistador", Henrique de Blois (filho de Adélia e de Estêvão, conde de Blois), foi educado em Cluny, na Borgonha, por desejo da mãe, e veio depois a ser bispo de Winchester; por pressão desta sua irmã Adélia, o rei Henrique I Beauclerc fundou, em 1121, a importante abadia de Reading. A partir da primeira metade do séc. XII, uma outra congregação beneditina, a de Cister, registou também um assinalável crescimento em Inglaterra: em 1153, à morte de São Bernardo de Claraval, a grande referência continental dos cistercienses, dispunha já de 50 casas. Também os premonstratenses, os agostinhos (sob Henrique I) e a Ordem do Templo (sob Matilde, a esposa do rei Estêvão) se afirmaram na Grã-Bretanha ao longo do séc. XII. Perante isto, não é de estranhar que a Crónica Anglo-Saxónica lamente a existência de um tão grande número de monges estrangeiros em Inglaterra...

Julgamos que este crescimento das casas religiosas estará diretamente ligado ao progresso da narrativa histórica. A maioria desses textos teve uma origem continental, mas não podemos esquecer nomes como Godofredo de Monmouth, bispo de Saint Asaph (no País de Gales). Foi Monmouth quem fixou (ainda em latim e em versos octossilábicos) os traços característicos das lendas associadas à "matéria da Bretanha", combinando narrativas anteriores (como a de Guilherme de Malmesbury) com elementos celtas e uma imaginação prodigiosa: vejam-se as "Profecias de Merlim" (c. 1134), a "Vida de Merlim" (c. 1148) e, sobretudo, a Historia Regum Britanniae ("História dos Reis da Bretanha"), composta cerca de 1136 e organizada em 12 livros, dos quais dois são consagrados ao rei Artur (vitória sobre os Saxões, guerra contra os Romanos, entre outros episódios). Nesta última obra, a espada mágica do rei, a revolta de Galvão, o senescal Queia e as personagens mais importantes do famoso ciclo romanesco são definitivamente consagradas. 
Uma palavra também para a iluminura anglo-saxónica, que, tendo atingido o seu apogeu por volta do ano 1000, foi revitalizada pelos Normandos quando estes reanimaram os scriptoria monásticos. Neste domínio, fez-se sentir uma clara influência italo-bizantina, o que é natural atendendo à forte presença normanda nesta região do sul da Europa. Assim, a partir de 1120, foram produzidas algumas obras-primas da iluminura românico-inglesa, como o Psaltério de Saint Albans, a Bíblia de Bury Saint Edmunds ou a Bíblia de Winchester (neste último caso, graças à ação do já referido Henrique de Blois, neto de Guilherme I).

No plano administrativo, a Inglaterra colocar-se-ia, ao longo do séc. XII, numa posição de vanguarda relativamente ao resto da Europa. Por exemplo, o Echiquier, um organismo encarregado das finanças régias criado no período anglo-normando, teve sessões regulares duas vezes por ano a partir de Henrique I (1100-1135). E a Normandia converteu-se num viveiro de talentos para a administração do reino, facto de que é bom exemplo Rogério de Salisbúria, um padre de Avranches com fortes ligações à escola de Laon e que presidiu ao Echiquier (o nome vem da tábua retangular, com tecido enxadrezado, onde se empilhavam as somas pagas ao rei pelos sheriffs) a partir do momento em que Ranulfo de Flambard caiu em desgraça junto do rei Henrique I. Um sobrinho de Rogério, chamado Nigel, seria, a partir de 1125, o primeiro servidor da coroa a ostentar oficialmente o título de "tesoureiro" do reino de Inglaterra.

Em conclusão, durante o século seguinte à conquista de 1066, teve lugar em Inglaterra uma síntese de elementos anglo-saxões e normandos (ao nível do direito, da administração e da cultura), o que - como observou Stephen Morillo - conduziu à criação de um reino anglo-normando trans-Canal da Mancha que era, em muitos aspetos, bem mais do que a soma das suas partes. A faceta mais importante desta síntese anglo-normanda foi, talvez, a combinação de um rei conquistador e de uma nova classe governante, por um lado, com os tribunais anglo-saxónicos, as tradições legais e os poderes régios, por outro. Como remata Morillo, isto ajudou a lançar os alicerces da common law inglesa, do constitucionalismo (veja-se a Magna Carta de João Sem Terra, em 1215) e do governo representativo. Todo este 
processo, desencadeado com a vitória de Guilherme "o Conquistador" na colina de Senlac naquele final de tarde de 14 de outubro de 1066, mudou a história de Inglaterra e da Europa até aos nossos dias.

\section{Fontes principais}

Mogens Rud, La Tapisserie de Bayeux et la bataille de Hastings 1066. Trad. francesa, 4. a ed., Christian Ejlers, Copenhague, 2001 (ed. orig.: 1983). Reprodução integral da tapeçaria, comentada.

Stephen Morillo, The Battle of Hastings. Sources and Interpretations. Woodbridge, The Boydell Press, 1996. Contém os extratos mais importantes de seis fontes: Guilherme de Poitiers, Guilherme de Jumièges, Crónica Anglo-Saxónica, Florêncio/João de Worcester, Tapeçaria de Bayeux e poema Carmen.

The Gesta Guillelmi of William of Poitiers, edited and translated by R. H. C. Davis and Marjorie Chibnall, Oxford, Clarendon Press, 2006 (ed. orig.: 1998).

\section{Leituras recomendadas}

Elisabeth M. C. van Houts, "The trauma of 1066", in History Today, n. ${ }^{\circ} 46,1996$ (pp. 9-15).

Guy Halsall, Warfare and Society in the Barbarian West, 450-900. Londres-Nova Iorque, Routledge, 2003.

Jim Bradbury, The Battle of Hastings. Sutton Publishing, 2005 (ed. orig.: 1998)

Kelly DeVries, The Norwegian Invasion of England in 1066. Woodbridge, The Boydell Press, 1999. Fundamental para o estudo das batalhas de Fulford Gate e, sobretudo, de Stamford Bridge, que precedem em escassos dias o combate de Hastings.

Kelly DeVries, "Hastings, 1066", in Martin Dougherty, Iain Dickie, Phyllis G. Jestice e Christer Jorgensen, Battles of the Medieval World, 1000-1500. From Hastings to Constantinople. London, Amber Books, 2006 (pp. 18-29).

Paula Dias, "A Tapeçaria de Bayeux, uma história em palavras e imagens", in Boletim de Estudos Clássicos, Faculdade de Letras da Universidade de Coimbra, n. ${ }^{\circ}$ 35, 2001 (pp. 99-114).

Philip Morgan, in Clifford J. Rogers (editor in chief), The Oxford Encyclopedia of Medieval Warfare and Military Technology, Oxford University Press, 2010, 3 vols. (vide: "Battle of Hastings", vol. 2, pp. 243-245).

Sophie Cassagnes-Brouquet, Histoire de l'Angleterre médiévale. Paris, Ophrys, 2000.

Stephen Morillo, The Battle of Hastings. Sources and Interpretations. Woodbridge, The Boydell Press, 1996. Inclui alguns dos estudos mais relevantes sobre a batalha e sobre o seu contexto histórico-militar, com textos de Bernard Bachrach, de Carroll Gillmor, de Christine e Gerald Grainge, de John Gillingham, de Marjorie Chibnall, de Richard Abels e de Ronny Allen Brown, para além do próprio Stephen Morillo. 
(Página deixada propositadamente em branco) 


\section{Cronologia Sumária}

\section{ANTES DE CRISTO}

490: Batalha de Maratona (vitória dos Gregos sobre Dario I, rei da Pérsia).

480: Batalha naval de Salamina (vitória grega sobre Xerxes, rei da Pérsia).

431-404: Guerra do Peloponeso, entre Atenas e diversas cidades gregas.

371: Batalha de Leuctras (os Tebanos de Epaminondas derrotam Esparta).

356: Nascimento de Alexandre, filho do rei Filipe II da Macedónia.

338: Batalha de Queroneia (vitória de Filipe II e de Alexandre na Grécia).

336: Assassinato de Filipe II. Alexandre Magno torna-se rei da Macedónia.

334: Batalha de Granico (primeira grande vitória de Alexandre sobre os Persas).

333: Batalha de Isso (vitória de Alexandre sobre Dario III da Pérsia).

332: Cerco e tomada de Tiro por Alexandre Magno.

331 (1 de outubro): Batalha de Gaugamela (vitória de Alexandre sobre Dario III).

326: Batalha de Hidaspes (vitória de Alexandre sobre Poro, rei indiano).

323: Morte de Alexandre Magno, em Babilónia.

264-241: Primeira Guerra Púnica, entre Roma e Cartago.

237: Amílcar Barca nomeado comandante da província cartaginesa da Hispânia.

220: Cerco de Sagunto por Aníbal Barca, filho de Amílcar.

218-201: Segunda Guerra Púnica.

218 (primavera): Início da longa marcha terrestre de Aníbal Barca, em direção a Itália.

218: Batalhas de Ticino (novembro) e de Trébia (dezembro) - Aníbal vence os Romanos.

217: Batalha do lago Trasimeno (Aníbal derrota mais um exército consular romano).

216 (2 de agosto): Batalha de Canas (estrondosa derrota romana às mãos de Aníbal Barca).

202: Batalha de Zama (Cipião "o Africano" derrota os Cartagineses liderados por Aníbal).

183: Suicídio de Aníbal Barca, na Bitínia.

149-146: Terceira Guerra Púnica (concluída com a destruição de Cartago por Cipião Emiliano).

27: Início do regime imperial em Roma, com o principado de Otávio Augusto.

\section{DEPOIS DE CRISTO}

14: Morte de Augusto. Início da dinastia romana dos Júlios-Cláudios.

69: Início da dinastia dos Flávios.

96: Início da dinastia dos Antoninos. 
101-117: Guerras do imperador Trajano na Dácia e, depois, na Pártia.

211-217: Principado de Caracala. A "Crise do séc. III" manifesta-se com toda a força.

284-305: Principado de Diocleciano; importantes reformas políticas e militares.

324-337: Principado de Constantino I como imperador único e incontestado.

364: Morte do imperador Joviano. Valentiniano I e Valente partilham o poder.

378 (9 de agosto): Batalha de Adrianopla (vitória dos Godos sobre Valente).

410: Tomada de Roma pelos Godos, chefiados por Alarico.

476: Deposição do último imperador romano do Ocidente, Rómulo Augústulo.

481: Início da governação de Clóvis, rei dos Francos e primeiro monarca merovíngio.

486: Batalha de Soissons (Clóvis derrota Siágrio, um chefe galo-romano).

496 (ou 506): Batalha de Tolbiac (Clóvis vence os Alamanos).

507: Batalha de Vouillé (Clóvis vence os Visigodos).

511: Morte de Clóvis e partilha do reino franco pelos seus quatro filhos.

571: Os Anglos derrotam os Bretões. Conquista anglo-saxónica de Inglaterra.

613-629: Clotário II, bisneto de Clóvis, impõe-se como rei único dos Francos.

629-639: Reinado de Dagoberto I. Pepino I torna-se prefeito do palácio da Austrásia.

680-714: Afirmação de Pepino II na Gália. Período dos "reis fantoches".

720-741: Carlos Martel derrota os seus opositores e domina todo o regnum Francorum.

732 (25-26 de outubro): Batalha de Poitiers (Carlos Martel derrota os muçulmanos).

751: Pepino III, "o Breve" (filho de Carlos Martel) torna-se o primeiro rei carolíngio.

768-814: Reinado de Carlos Magno. Construção do "Império Carolíngio".

843: Tratado de Verdun (partilha do império pelos netos de Carlos Magno).

843-877: Reinado de Carlos "o Calvo" na França ocidental. Ataques violentos dos Vikings.

871-899: Reinado de Alfredo "o Grande” em Inglaterra (unificação da resistência anglo-saxónica contra a tentativa de domínio nórdico).

911: Tratado de Saint-Clair-sur-Epte (instalação dos Vikings, liderados por Rolf Ganger, na Normandia).

987: Início da dinastia capetíngia, em França, com a ascensão de Roberto Hugo Capeto. 1013-1042: Os Dinamarqueses governam a Inglaterra.

1027/28: Nascimento de Guilherme (tetraneto de Rolf e duque da Normandia).

1035: Morte de Roberto I (pai de Guilherme). Instabilidade na Normandia.

1042-1066: Reinado de Eduardo "o Confessor", em Inglaterra.

1047: Batalha de Val-ès-Dunes (Guilherme e o rei de França vencem os rebeldes normandos).

1057: Batalha de Varaville (vitória de Guilherme sobre o rei de França e o conde de Anjou). 1066 (janeiro): Morte de Eduardo "o Confessor". Haroldo II sobe ao trono de Inglaterra.

1066 (20 de setembro): Batalha de Fulford Gate (o rei Hardrada da Noruega vence um exército condal inglês).

1066 (25 de setembro): Batalha de Stamford Bridge (vitória de Haroldo II sobre Hardrada da Noruega e Tostig Godwinson).

1066 (14 de outubro): Batalha de Hastings (vitória de Guilherme, morte de Haroldo II e conquista normanda da Inglaterra).

1077: Dedicação da catedral de Bayeux (Caen). Inauguração da Tapeçaria de Bayeux.

1085-1087: Elaboração do Domesday Book (monumental recenseamento, em Inglaterra).

1087: Morte de Guilherme "o Conquistador".

1154-1189: Reinado de Henrique II (bisneto de Guilherme e líder do vasto império angevino). 


\section{Índice das Ilustrações}

\section{Cap. 1 - Gaugamela}

Mapa da Grécia central e meridional .................................................... 24

Pintura policromática representando os Imortais .......................................... 31

Vaso ateniense representando um takabara a combater um hoplita ...................... 34

Falange macedónica vista de frente ....................................................... 45

Mapa da campanha de Alexandre Magno e do seu império ................................ 49

Esquema da batalha de Gaugamela - posições iniciais .................................... 57

Esquema da batalha de Gaugamela - fase crucial .........................................6 63

Cap. 2 - Canas

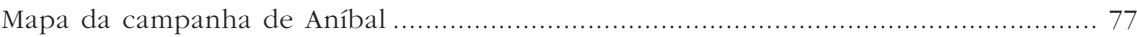

Legionário romano de finais do séc. I d. C. em formação de combate ..................... 89

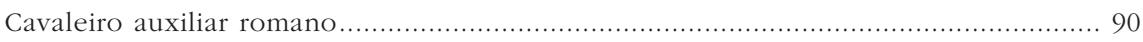

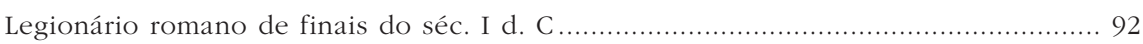

Soldado de infantaria auxiliar romana de finais do séc. I d. C ............................. 93

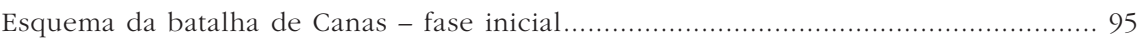

Esquema da batalha de Canas - fase crítica.................................................. 101

\section{Cap. 3 - Adrianopla}

Mapa do Império Romano sob Trajano ................................................. 111

Mapa do mundo romano em finais do séc. IV d. C ................................... 121

Cavaleiro e peão romanos; peão visogodo e cavaleiro ostrogodo .......................... 126

Esquema da batalha de Adrianopla ................................................... 131

\section{Cap. 4 - Poitiers}

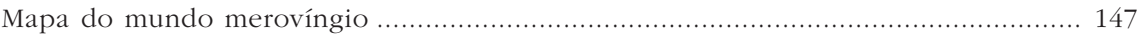

Esquema genealógico: os Merovíngios, de Clóvis a Dagoberto I............................. 153

Esquema genealógico: os Merovíngios, de Dagoberto I a Childerico III ................. 157

Cavalaria muçulmana equipada com armamento ligeiro .................................... 161

Exército franco formando uma "parede de escudos" ........................................ 173

Esquema da batalha de Poitiers ..................................................... 181 


\section{Cap. 5 - Hastings}

Mapa da Inglaterra na Alta Idade Média 199

Pormenor da Tapeçaria de Bayeux: campanha de Guilherme e de

Haroldo Godwinson na Bretanha

Pormenor da Tapeçaria de Bayeux: os Normandos preparam a

travessia do Canal da Mancha 237

Pormenor da Tapeçaria de Bayeux: o duque viaja para Inglaterra ....................... 241

Mapa da conquista normanda de Inglaterra .......................................... 245

Esquema dos arredores de Battle ........................................................ 261

Pormenor da Tapeçaria de Bayeux: o exército normando deixa Hastings................ 265

Pormenor da Tapeçaria de Bayeux: a testa da coluna normanda acelera o passo .... 267

Esquema da batalha de Hastings. Fase 1: Abertura ......................................... 271

Pormenor da Tapeçaria de Bayeux: os Normandos atacam o exército anglo-saxónico

Pormenor da Tapeçaria de Bayeux: o exército anglo-saxónico

responde ao ataque normando 275

Esquema da batalha de Hastings. Fase 2: Pânico entre os Normandos ................... 277

Esquema da batalha de Hastings. Fase 3: Guilherme salva o dia ........................... 279

Pormenor da Tapeçaria de Bayeux: morte dos irmãos do rei Haroldo II ................. 281

Esquema da batalha de Hastings. Fase 4: Cargas e fugas simuladas....................... 283

Esquema da batalha de Hastings. Fase 5: Assalto final ...................................... 287

Pormenor da Tapeçaria de Bayeux: morte do rei inglês ................................ 289

Esquema da batalha de Hastings. Fase 6: Vitória normanda .................................. 291 
(Página deixada propositadamente em branco) 
Série Investigação

-

Imprensa da Universidade de Coimbra

Coimbra University Press

2012

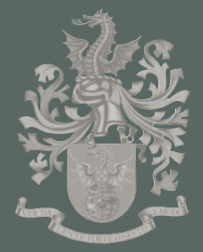

Comissio Portugue

de História Militar

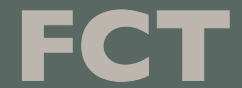

Fundação para a Ciência e a Tecnologi

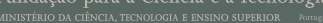

- U

C

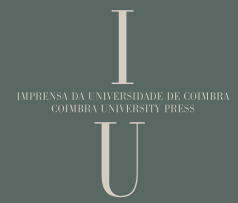

